FLOOD OF JULY 9-11, 1993, IN THE RACCOON RIVER BASIN, WEST-CENTRAL IOWA

By David A. Eash and Barbara A. Koppensteiner

U.S. GEOLOGICAL SURVEY

Open-File Report 97-557

Prepared in cooperation with the

IOWA HIGHWAY RESEARCH BOARD and the PROJECT DEVELOPMENT DIVISION of the IOWA DEPARTMENT OF TRANSPORTATION (IOWA DOT Research Project HR-140) 


\section{U.S. DEPARTMENT OF THE INTERIOR BRUCE BABBITT, Secretary}

U.S. GEOLOGICAL SURVEY

MARK SCHAEFER, Acting Director

For additional information write to:

District Chief

U.S. Geological Survey

Room 269, Federal Building

400 South Clinton Street

lowa City, lowa 52244
Copies of this report can be purchased from:

U.S. Geological Survey

Branch of Information Services Box 25286, Denver Federal Center Denver, Colorado 80225-0286 


\section{CONTENTS}

Abstract

Introduction

Purpose and scope.

Acknowledgments.

Study area..

Hydrologic data

Floodflow frequencies

Flood history

Additional publications

Flood of June 1947

Flood of July 2-3, 1958.

Flood of March 19-25, 1979

Floods of May 10, and June 29- July 1, 1986.

Flood of June 16-19, 1990

Flood of July 9-11, 1993

Profiles for the flood of July 9-11, 1993, in the Raccoon River Basin, west-central Iowa

Considerations.

Summary

References

Appendix A. Peak stages and discharges for streamflow-gaging stations in the Raccoon River Basin, west-central lowa

Appendix B. Water-surface-elevation profiles for the Raccoon River Basin, west-central Iowa..

Appendix C. Temporary bench marks and reference points in the Raccoon River Basin, west-central Iowa

\section{FIGURES}

1. Map of the Raccoon River Basin:

1A. showing location of bridge sites used in the July 9-11, 1993, flood profiles and U.S. Geological Survey streamflow-gaging stations

1B. showing area within Polk County, location of bridge sites used in the July 9-11, 1993, flood profile, U.S. Geological Survey streamflow-gaging stations, and selected roads in Polk County

2. Map showing areal distribution of rainfall for the July 8-9, 1993, storm in the Raccoon River Basin and in Iowa

3. Graph showing cumulative rainfall for July 8-9, 1993, at Coon Rapids, the Des Moines Airport, and Rockwell City, Iowa

4. Graph showing discharge at the Raccoon River at Van Meter streamflow-gaging station July 8 through July 19, 1993

5. Graph showing water-surface-elevation profiles for the flood of July 9-11, 1993, along the Raccoon, North Raccoon, South Raccoon, and Middle Raccoon Rivers and Brushy Creek, river miles 0.05-126.03.

6. Graph showing water-surface-elevation profiles for the Raccoon and North Raccoon Rivers, river miles 0.05-100.91

7. Graphs showing water-surface-elevation profiles for the Raccoon River,:

7A. river miles 0.05-15

7B. river miles 15-30. 


\section{FIGURES--Continued}

8. Graph showing water-surface-elevation profiles for the North Raccoon River, river miles,

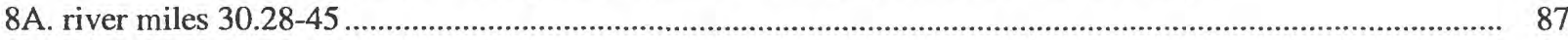

8B. river miles 45-60

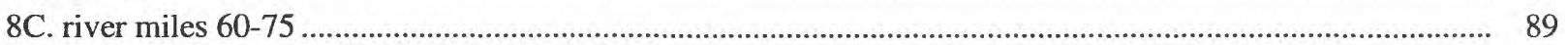

8D. river miles 75-90

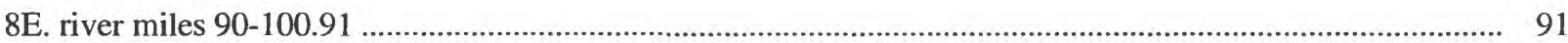

9. Graph showing water-surface-elevation profiles for Mill Slough (South Channel of the North Raccoon River), river miles 39.69-42.40 .......................................................................................................... 92

10. Graph showing water-surface-elevation profiles for the South Raccoon River, river miles 30.28-96.36 .............. 93

11. Graphs showing water-surface-elevation profiles for the South Raccoon River,

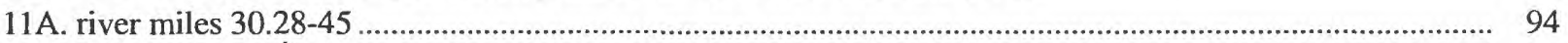

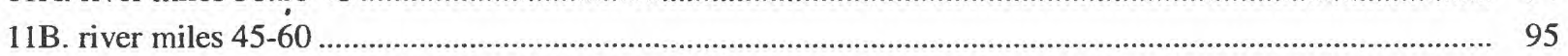

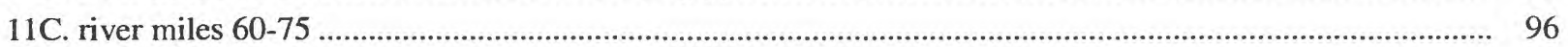

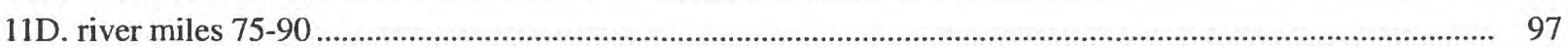

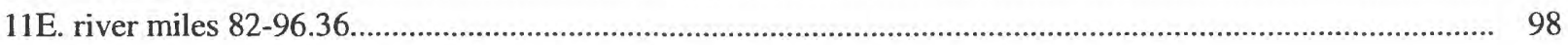

12. Graph showing water-surface-elevation profiles for Brushy Creek, river miles 3.44-40.84 ................................ 99

13. Graphs showing water-surface-elevation profiles for the Brushy Creek,:

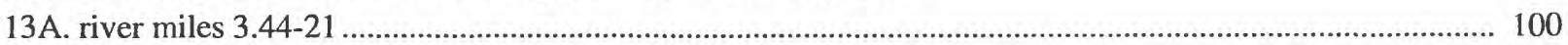

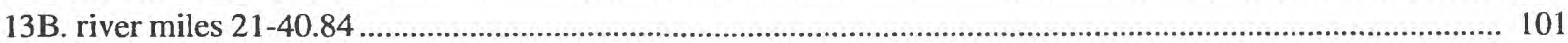

14. Graph showing water-surface-elevation profiles for the Middle Raccoon River, river miles 48-126.03 ............... 102

15. Graphs showing water-surface-elevation profiles for the Middle Raccoon River,:

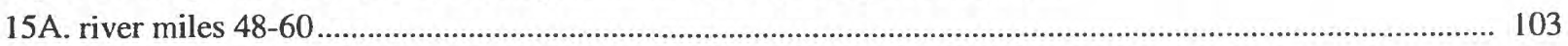

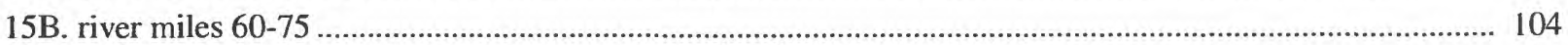

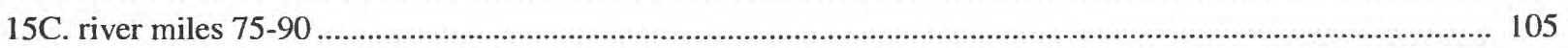

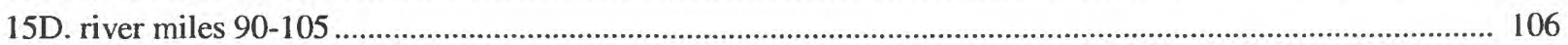

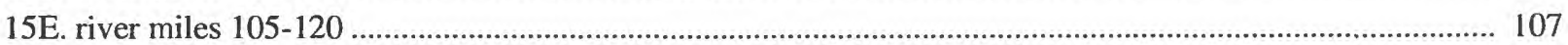

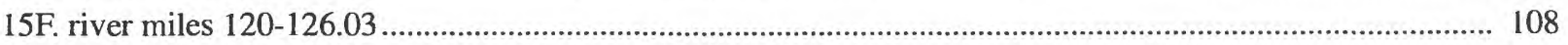

16. Graph showing water-surface-elevation profiles for Storm Creek, river miles 1.43-11.17 ................................ 109

\section{TABLES}

1. Floodflow frequencies for streamflow-gaging stations in the Raccoon River Basin

2. Selected flood-peak discharges, recurrence intervals, and unit runoff for streamflow-gaging stations in the Raccoon River Basin 
CONVERSION FACTORS, ABBREVIATIONS, AND VERTICAL DATUM

\begin{tabular}{|c|c|c|}
\hline Multiply & By & To obtain \\
\hline inch (in.) & 25.4 & millimeter \\
\hline foot $(\mathrm{ft})$ & 0.3048 & meter \\
\hline mile (mi) & 1.609 & kilometer \\
\hline square mile $\left(\mathrm{mi}^{2}\right)$ & 2.590 & square kilometer \\
\hline cubic foot per second $\left(\mathrm{ft}^{3} / \mathrm{s}\right)$ & 0.02832 & cubic meter per second \\
\hline $\begin{array}{l}\text { cubic foot per second per } \\
\text { square mile }\left[\left(\mathrm{ft}^{3} / \mathrm{s}\right) / \mathrm{mi}^{2}\right]\end{array}$ & 0.01093 & $\begin{array}{l}\text { cubic meter per second } \\
\text { per square kilometer }\end{array}$ \\
\hline ton per acre & 2.242 & megagram per square hectometer \\
\hline
\end{tabular}

Sea Level: In this report, "sea level" refers to the National Geodetic Vertical Datum of 1929--a geodetic datum derived from a general adjustment of the first-order level nets of the United States and Canada, formerly called Sea Level Datum of 1929. 


\title{
Flood of July 9-11, 1993, in the Raccoon River Basin, West-Central lowa
}

\author{
by David A. Eash and Barbara A. Koppensteiner
}

\section{ABSTRACT}

Water-surface-elevation profiles and peak discharges for the flood of July 9-11, 1993, in the Raccoon River Basin, west-central Iowa, are presented in this report. The profiles illustrate the 1993 flood along the Raccoon, North Raccoon, South Raccoon, and Middle Raccoon Rivers and along Brushy and Storm Creeks in the west-central Iowa counties of Carroll, Dallas, Greene, Guthrie, and Polk. Water-surface-elevation profiles for the floods of June 1947, March 1979, and June 29-

July 1, 1986, in the Raccoon River Basin also are included in the report for comparative purposes. The July 9-11, 1993, flood is the largest known peak discharge at gaging stations Brushy Creek near Templeton (station number 05483318) 19,000 cubic feet per second, Middle Raccoon River near Bayard (station number 05483450) 27,500 cubic feet per second, Middle Raccoon River at Panora (station number 05483600) 22,400 cubic feet per second, South Raccoon River at Redfield (station number 05484000) 44,000 cubic feet per second, and Raccoon River at Van Meter (station number 05484500) 70,100 cubic feet per second. The peak discharges were, respectively, $1.5,1.3,1.1,1.2$, and 1.3 times larger than calculated 100-year recurrenceinterval discharges. The report provides information on flood stages and discharges and floodflow frequencies for streamflow-gaging stations in the Raccoon River Basin using flood information collected through 1996. A flood history summarizes rainfall conditions and damages for floods that occurred during 1947, 1958, 1979, 1986, 1990, and 1993. Information on temporary bench marks and reference points established in the Raccoon River Basin during 1976-79 and 1995-97 also is included in the report.

\section{INTRODUCTION}

Evaluation of flood hazards and the planning, design, and operation of various structures on flood plains require information about floods. Flood-profile reports provide water-surface-elevation profiles and specific information for selected floods and are used by planners and engineers to evaluate the magnitude and frequency of floods in a river basin. This flood-profile report was prepared by the U.S. Geological Survey (USGS) in cooperation with the Iowa Highway Research Board and the Project Development Division of the Iowa Department of Transportation.

\section{Purpose and Scope}

This report presents water-surface-elevation profiles for the flood of July 9-11, 1993, in the Raccoon River Basin in west-central Iowa. Profiles for the floods of June 1947, March 1979, and June 29-July 1, 1986, in the Raccoon River Basin also are presented in this report for comparative purposes. The report provides information on flood stages and discharges and floodflow frequencies for streamflow-gaging stations in the Raccoon River Basin using flood information collected through 1996. A flood history summarizes rainfall conditions and damages for floods that occurred during 1947, 1958, 1979, 1986, 1990, and 1993. Information on temporary bench marks and reference points established in the Raccoon River Basin during 1976-79 and 1995-97 also is included in the report.

\section{Acknowledgments}

Various Federal, State, and local agencies cooperated in the collection of streamflow records used in this report, the acknowledgment of which is contained 
in the annual water-data reports of the USGS (U.S. Geological Survey, 1916-97). The authors express their gratitude to the following: G. F. Grimm, S. G. Hill, R. L. Kopish, R. L. Kuzniar, T. C. Melcher, J. M. Pohl, D. J. Tanko, and K. G. Umstattd for collecting the field data for the 1993 flood and surveying level-lines, and for collecting and processing global-positioningsystem data, to establish sea-level elevations for the temporary bench marks and reference points; and T. L. Birkenholtz for preparing the maps for this report.

\section{STUDY AREA}

The Raccoon River Basin is located in west-central Iowa, includes parts of 17 counties, and drains as a right bank tributary to the Des Moines River within the City of Des Moines (fig. 1A). The basin is oriented in a general northwest-southeast direction and covers $3,629 \mathrm{mi}^{2}$ (Larimer, 1957, p. 337). Three principal rivers drain the Raccoon River Basin, the North Raccoon, the South Raccoon, and the Middle Raccoon Rivers. The North Raccoon and South Raccoon Rivers, with drainage areas of 2,298 and $1,143 \mathrm{mi}^{2}$, respectively (Larimer, 1957, p. 114-115), join northwest of Van Meter in Dallas County to form the Raccoon River. The Raccoon River proper, consists of a 30.28-mi long reach that flows across eastern Dallas and western Polk Counties. The Middle Raccoon River is a tributary to the South Raccoon River; the mouth of the Middle Raccoon River is south of Redfield in Dallas County. Land use in west-central Iowa is primarily row-crop agriculture with some livestock operations.

In general, the topography of the Raccoon River Basin developed as a result of repeated continental glacial advances across west-central lowa, during which the land was scoured and thick deposits of glacial till were deposited. Periods of glaciation were followed by interglacial periods of erosion. The majority of the Raccoon River Basin lies within two landform regions of the State, the Des Moines Lobe and the Southern Iowa Drift Plain (fig. 1A) (Prior, 1991, p. 31-34). In the extreme northwest part of the basin, a small part of the basin lies within a third landform region, the Northwest Iowa Plains. The Des Moines Lobe landform region is characteristic of a young, postglacial landscape that is unique with respect to the rest of the State (Prior, 1991, p. 30-47). The Des Moines Lobe outlines the last glacial advance into Iowa, which ended at what is now the
City of Des Moines, and in the process established the present course of the Raccoon River (Prior, 1991, p. 36-37). The Des Moines Lobe generally comprises low-relief terrain, accentuated by natural lakes, potholes, and marshes, where surface-water drainage typically is poorly defined and sluggish. Soils of the Des Moines Lobe do not include a loess cover and generally consist of friable, calcareous loam glacial till with thick deposits of compact, uniform pebbly loam (Oschwald and others, 1965, p. 28; Prior, 1991, p. 34 and 39). The Southern Iowa Drift Plain landform region is characteristic of a mature postglacial landscape that has eroded to form a steeply to gently rolling topography and a well-established drainage system; common terrain characteristics are integrated drainage networks, stepped erosional surfaces, and exposed bedrock in the deeper alluvial valleys (Prior, 1991, p. 34 and 58-61; Iowa Natural Resources Council, 1953, p. 3 and 7). Soils of the Southern Iowa Drift Plain in the Raccoon River Basin generally consist of moderately-permeable, silty-clay loam to silty clay that formed from loess-covered glacial till under prairie vegetation; loess deposits in the area range from 100 to $200 \mathrm{in}$. (8.3 to $16.7 \mathrm{ft}$ ) (Oschwald and others, 1965 p. $6,52-53$, and $63-65)$.

Approximately 78 percent of the Raccoon River Basin, including nearly the entire North Raccoon River Basin, lies within the Des Moines Lobe landform region. The South Raccoon River Basin, upstream from the mouth of the Middle Raccoon River, lies entirely within the Southern Iowa Drift Plain landform region. The Middle Raccoon River generally marks the boundary between the Des Moines Lobe and the Southern Iowa Drift Plain; the Middle Raccoon River Basin lies within both of these landform regions. Thus, the Raccoon River Basin is characterized by two distinct topographic landscapes, the youthful topography of the Des Moines Lobe and the mature topography of the Southern Iowa Drift Plain. The transition between these two landform regions is abrupt on either side of the Middle Raccoon River.

\section{HYDROLOGIC DATA}

Gaging-station records are the primary source of data for analyzing and understanding the flood hydrology of a river basin. Flood information is obtained 
from complete-record streamflow-gaging stations, which provide a continuous chronology of streamflow, and from partial-record, crest-stage streamflow-gaging stations, which provide a chronology of annual peakflows. The location of 19 USGS gaging stations in the Raccoon River Basin are shown in figure 1; 12 are active gaging stations (nine continuous-record gages and three crest-stage gages) and seven are discontinued gaging stations (four continuous-record gages and three crest-stage gages). The specific location, annual peak stages and discharges, and other information pertaining to each gaging station are presented in Appen$\operatorname{dix} A$. Discharge records collected during the operation of these gaging stations are published in the annual water-data reports of the USGS (U.S. Geological Survey, 1916-97).

The computation of discharge records at a gaging station is dependent upon the development of a stagedischarge relation, or rating curve, between watersurface elevations (stages) and the corresponding flow rates (discharges). The high-water part of the stagedischarge relation generally remains stable if the channel downstream from the gaging station remains unchanged. Changes in the stage-discharge relation occur from time to time, either gradually or abruptly, due to changes in the stream channel that result from scour, deposition, the growth of vegetation, or the construction of dams, bridges, or levees (Rantz and others, 1982, p. 328-360).

Mean annual precipitation for 1961-90 at rain gages within the Raccoon River Basin are summarized as follows (Owenby and Ezell, 1992, p. 22-25).

\begin{tabular}{llll}
\hline \multicolumn{4}{c}{ Rain gage and mean annual precipitation for 1961-90, in } \\
inches
\end{tabular}

Mean annual runoff at selected locations within the Raccoon River Basin was determined at the following streamflow-gaging stations for the following water years (May and others, 1997, p. 257-275).

\begin{tabular}{|c|c|c|c|}
\hline $\begin{array}{l}\text { Station } \\
\text { number }\end{array}$ & Station name & $\begin{array}{c}\text { Period of } \\
\text { record } \\
\text { (water years) }\end{array}$ & $\begin{array}{c}\text { Mean } \\
\text { annual runoff, } \\
\text { in inches }\end{array}$ \\
\hline 05482300 & $\begin{array}{l}\text { North Raccoon } \\
\text { River near Sac City }\end{array}$ & $1959-96$ & 7.71 \\
\hline 05482500 & $\begin{array}{l}\text { North Raccoon } \\
\text { River near Jefferson }\end{array}$ & $1941-96$ & 6.71 \\
\hline 05483450 & $\begin{array}{l}\text { Middle Raccoon } \\
\text { River near Bayard }\end{array}$ & $1980-96$ & 9.13 \\
\hline 05483600 & $\begin{array}{l}\text { Middle Raccoon } \\
\text { River at Panora }\end{array}$ & $1959-96$ & 7.30 \\
\hline 05484000 & $\begin{array}{l}\text { South Raccoon } \\
\text { River at Redfield }\end{array}$ & $1941-96$ & 6.76 \\
\hline 05484500 & $\begin{array}{l}\text { Raccoon River at Van } \\
\text { Meter }\end{array}$ & $1916-96$ & 6.01 \\
\hline 05484800 & $\begin{array}{l}\text { Walnut Creek at Des } \\
\text { Moines }\end{array}$ & $1972-96$ & 10.94 \\
\hline
\end{tabular}

\section{FLOODFLOW FREQUENCIES}

The magnitude and frequency of flood discharges, or floodflow frequencies, for a streamflowgaging station are determined from a flood-frequency curve which relates observed annual-peak discharges to annual exceedance probability or recurrence interval. Annual exceedance probability is expressed as the chance that a specified flood magnitude will be exceeded in any 1 year. Recurrence interval, which is the reciprocal of the annual exceedance probability, is the statistical average number of years between exceedances of a specified flood magnitude. For example, a flood with a magnitude that is expected to be exceeded on average once during any 100 -year period (recurrence interval) has a 1-percent chance (annual exceedance probability $=0.01$ ) of being exceeded during any particular year. This flood, commonly termed the 100-year flood, is the theoretical peak discharge against which actual flood peaks generally are compared. Although the recurrence interval represents the long-term average period between floods of a specific magnitude, rare floods could occur at shorter intervals or even within the same year.

Floodflow frequencies computed for a gaging station, and recurrence intervals determined for selected flood peaks, are statistics that can change as more data become available. Statistics become more reliable as more data are collected and used in the computations. USGS streamflow-gaging stations are the primary source of the streamflow data used in the computations presented in this report. 

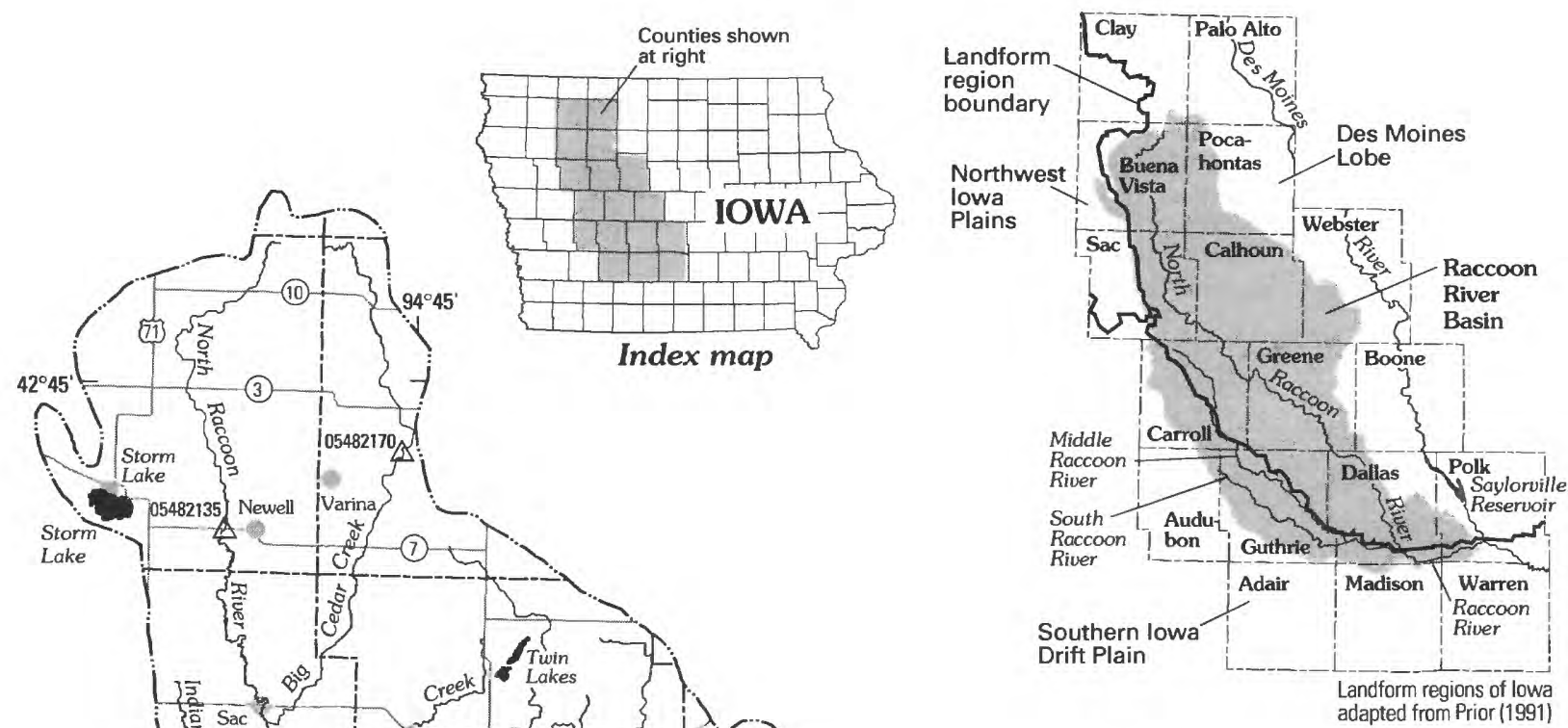

\section{EXPLANATION}

-.- Drainage-basin boundary

05482500 Continuous-record streamflow-gaging station and number

${ }^{05483000} \triangle$ Discontinued continuous-record streamflow-gaging station and number

${ }^{05482900} \hat{A}$ Crest-stage streamflow-gaging station and number

${ }^{05482800} \hat{\wedge}$ Discontinued crest-stage streamflowgaging station and number

- Ungaged bridge sites used in 1993 profiles
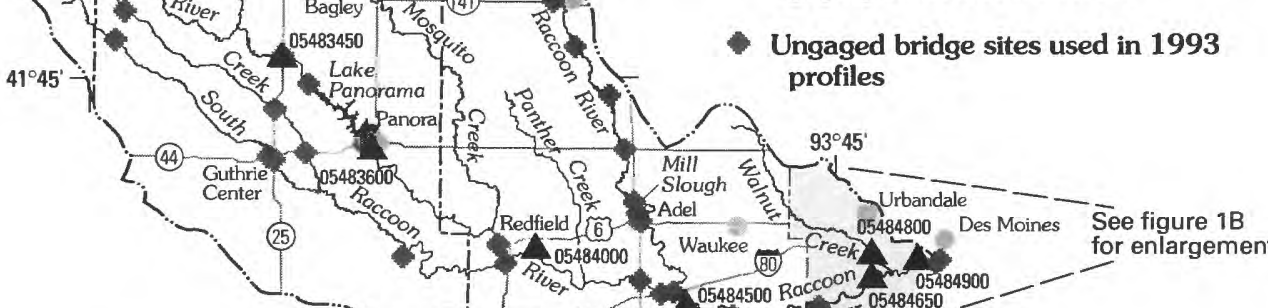

Base from U.S. Geological Survey digital data, 1:100,000, 1991 Universal Transverse Mercator projection van M Zone 15

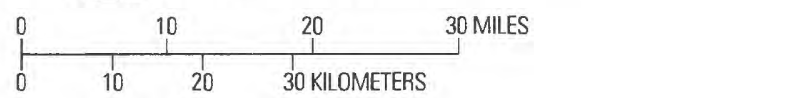

Figure 1A. Raccoon River Basin showing location of bridge sites used in July 9-11, 1993, flood profiles and U.S. Geological Survey streamflow-gaging stations. 


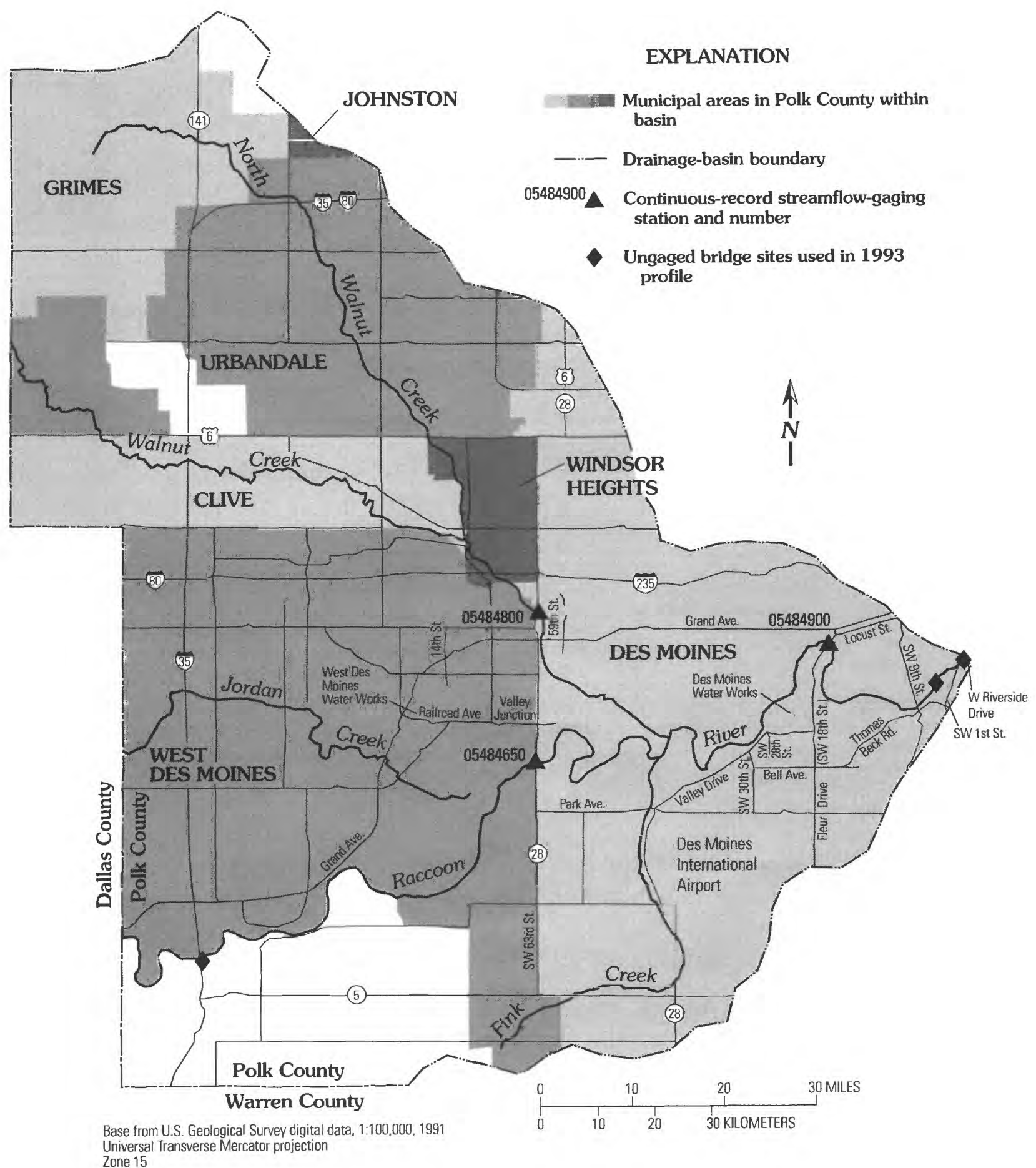

Figure 1B. Raccoon River Basin showing area within Polk County, location of bridge sites used in the July 9-11,1993, flood profile, U.S. Geological Survey streamflow-gaging stations, and selected roads in Polk County. 
The method used in this report for determining floodflow frequencies from streamflow data is outlined in Bulletin 17B of the Interagency Advisory Committee on Water Data (1982, p. 1-28). The Interagency Advisory Committee recommends using the Pearson Type-III distribution with log transformation of the data, commonly known as the log-Pearson Type-III distribution, as a base method for determining floodflow frequencies. At least 10 years of gaged annualpeak discharges are required to compute floodflow frequencies using this method. In this report, this method for determining floodflow frequencies is referred to as the "Bulletin 17B" method.

Three methods for estimating floodflow frequencies at stream sites in Iowa, including those not gaged, are described by Lara (1987, p. 2-19) and Eash (1993, p. 9-41). Lara (1987) used the physiographic characteristics of Iowa as a guide in defining the boundaries of five hydrologic regions. Regional equations were developed by using the floodflow frequencies for all gaged stations in a hydrologically, homogeneous area, thereby reducing potential errors associated with nonrepresentative, short-term record stations. Eash (1993) developed two other methods for estimating floodflow frequencies for stream sites in Iowa. In one method, significant drainage-basin characteristics were related to the floodflow frequencies for 164 streamflow-gaging stations in Iowa. In the other method, significant onsite channel-geometry characteristics were related to the floodflow frequencies for 157 streamflow-gaging stations in Iowa. Both Lara and Eash used the Bulletin 17B method as the base method for developing their flood-estimation equations.

The floodflow frequencies computed using the Bulletin 17B method, the regional method of Lara (1987), and the drainage-basin and channel-geometry characteristic methods of Eash (1993) are listed in table 1 for the gaging stations in the Raccoon River Basin. Differences in computed discharges between the four flood-estimation methods result from inherent differences between the methods and from differences in the periods of streamflow record that were used in the computation of each method. Flood-frequency discharges computed using the Bulletin 17B method used streamflow data collected through the 1996 water year; the regional method developed by Lara used data collected through the 1984 water year; and the drainage-basin and channel-geometry methods developed by Eash used data collected through the 1990 water year. It is noted that different flood-frequency discharges might be computed using the Bulletin 17B method if analyses use different periods of record, different approaches to weighting the skewness (asymmetry) of the frequency distribution of the annual peak discharges, or different approaches to incorporating historical flood information.

\section{FLOOD HISTORY}

Continuous records of streamflow have been collected in the Raccoon River Basin since April 1915 at streamflow-gaging station Raccoon River at Van Meter (station number 05484500 , fig. 1 A). Appendix A contains a complete list of flood peaks for the 19 streamflow-gaging stations in the Raccoon River Basin. Selected flood-peak discharges, including maximum known flood-peak discharges, and recurrence intervals for these gaging stations are listed in table 2.

\section{Additional Publications}

Additional information on floods in the Raccoon River Basin can be found in the following USGS publications. Approximate areas inundated in Des Moines and vicinity by the Raccoon River floods of June 13, 1947, and April 2, 1960, and by Walnut Creek during the flood of June 12, 1947, are described in the hydrologic atlas "Floods at Des Moines, Iowa" (Myers, 1963). Water-surface profiles and rating curves computed for a 4-mi reach of the Raccoon River upstream from the mouth are described in the report "WaterSurface Profiles of Raccoon River at Des Moines, Iowa" (Carpenter and Appel, 1966). The purpose of the 1966 report was to show the effect on water-surface profiles of raising the road-grade elevation of Fleur Drive roadway in Des Moines (fig. 1B). A study to assess the impact of urban development on the magnitude and frequency of flooding in the lower reach of the Walnut Creek Basin (fig. 1B) is described in the report "Effects of Urban Development on the Flood-Flow Characteristics of the Walnut Creek Basin Des Moines Metropolitan Area, Iowa" (Lara, 1978). Water-surfaceelevation profiles (including profiles along the North

Raccoon River upstream to the Sac-Buena Vista County line) and peak discharges for the March 1979 flood in the Raccoon River Basin, and flood information collected through 1978 for streamflow-gaging stations in the Raccoon River Basin, are presented in the 
Table 1. Floodflow frequencies for streamflow-gaging stations in the Raccoon River Basin

[Water year, October I-September 30; mi $^{2}$, square mile; 17B, Bulletin 17B (Interagency Advisory Committee on Water Data, 1982); Lara, hydrologic-region flood-frequency equations (Lara, 1987, p. 28); DB, drainage-basin characteristic flood-frequency equations (Eash, 1993, p. 17); CG, channel-geometry characteristic flood-frequency equations (Eash, 1993, p. 25); --, not determined]

\begin{tabular}{|c|c|c|c|c|c|c|c|c|c|c|}
\hline \multirow{2}{*}{$\begin{array}{l}\text { Station } \\
\text { number } \\
\text { (fig. 1A) }\end{array}$} & \multirow[b]{2}{*}{ Station name } & \multirow{2}{*}{$\begin{array}{l}\text { Drain- } \\
\text { age area } \\
\left(\mathrm{mi}^{2}\right)\end{array}$} & \multirow{2}{*}{$\begin{array}{l}\text { Period of } \\
\text { flood record } \\
\text { a(water year) }\end{array}$} & \multirow[b]{2}{*}{ Method } & \multicolumn{6}{|c|}{$\begin{array}{l}\text { Discharge, in cubic feet per second, } \\
\text { for indicated recurrence interval, in years }\end{array}$} \\
\hline & & & & & 2 & 5 & 10 & 25 & 50 & 100 \\
\hline \multirow[t]{4}{*}{05482135} & \multirow{4}{*}{$\begin{array}{l}\text { North Raccoon } \\
\text { River near } \\
\text { Newell }\end{array}$} & \multirow[t]{4}{*}{233} & \multirow{4}{*}{$\begin{array}{l}\text { 1983-93, } \\
1995\end{array}$} & $17 \mathrm{~B}$ & 1,530 & 2,380 & 2,920 & 3,570 & 4,030 & 4,460 \\
\hline & & & & ${ }^{b_{L}}$ ara & 2,060 & 3,390 & 4,450 & 5,900 & 6,570 & 7,850 \\
\hline & & & & DB & 1,320 & 2,430 & 3,290 & 4,390 & 5,240 & 6,100 \\
\hline & & & & CG & -- & -- & -- & -- & - & - \\
\hline \multirow[t]{4}{*}{05482170} & \multirow{4}{*}{$\begin{array}{l}\text { Big Cedar } \\
\text { Creek near } \\
\text { Varina }\end{array}$} & \multirow[t]{4}{*}{80.0} & \multirow[t]{4}{*}{$1960-91$} & $17 \mathrm{~B}$ & 660 & 1,290 & 1,750 & 2,350 & 2,800 & 3,250 \\
\hline & & & & ${ }^{\mathrm{b}}$ Lara & 905 & 1,570 & 2,110 & 2,850 & 3,250 & 3,920 \\
\hline & & & & DB & 691 & 1,350 & 1,860 & 2,540 & 3,080 & 3,630 \\
\hline & & & & ${ }^{c} \mathrm{CG}$ & 512 & 1,000 & 1,360 & 1,910 & 2,330 & 2,760 \\
\hline \multirow[t]{4}{*}{05482300} & \multirow{4}{*}{$\begin{array}{l}\text { North Raccoon } \\
\text { River near Sac } \\
\text { City }\end{array}$} & \multirow[t]{4}{*}{700} & \multirow{4}{*}{$\begin{array}{l}1954, \\
1958-96\end{array}$} & $17 \mathrm{~B}$ & 3,930 & 7,580 & 10,100 & 13,400 & 15,700 & 17,900 \\
\hline & & & & ${ }^{\mathrm{b}}$ Lara & 4,810 & 7,490 & 9,610 & 12,500 & 13,600 & 16,000 \\
\hline & & & & DB & 4,010 & 7,080 & 9,360 & 12,200 & 14,400 & 16,600 \\
\hline & & & & ${ }^{\mathrm{d}} \mathrm{CG}$ & 4,200 & 7,470 & 9,810 & 12,700 & 15,200 & 17,700 \\
\hline \multirow[t]{4}{*}{05482500} & \multirow{4}{*}{$\begin{array}{l}\text { North Raccoon } \\
\text { River near } \\
\text { Jefferson }\end{array}$} & \multirow[t]{4}{*}{1,619} & \multirow[t]{4}{*}{$1940-96$} & $17 \mathrm{~B}$ & 7,100 & 12,700 & 16,600 & 21,400 & 24,900 & 28,300 \\
\hline & & & & ${ }^{b_{\text {Lara }}}$ & 9,170 & 13,700 & 17,300 & 22,100 & 23,600 & 27,700 \\
\hline & & & & DB & -- & -- & -- & -- & -- & - \\
\hline & & & & ${ }^{d} \mathrm{CG}$ & 6,730 & 11,700 & 15,200 & 19,500 & 23,100 & 26,800 \\
\hline \multirow[t]{4}{*}{05482600} & \multirow{4}{*}{$\begin{array}{l}\text { Hardin Creek at } \\
\text { Farnhamville }\end{array}$} & \multirow[t]{4}{*}{43.7} & $1952-90$ & 17B & 505 & 981 & 1,350 & 1,870 & 2,290 & 2,720 \\
\hline & & & & ${ }^{\mathrm{b}}$ Lara & 568 & 1,020 & 1,380 & 1,890 & 2,180 & 2,640 \\
\hline & & & & DB & 298 & 592 & 832 & 1,160 & 1,420 & 1,700 \\
\hline & & & & ${ }^{\mathrm{d}} \mathrm{CG}$ & 442 & 890 & 1,250 & 1,740 & 2,150 & 2,600 \\
\hline 05482800 & Happy Run at & 7.58 & $1951-89$ & $17 \mathrm{~B}$ & 39.0 & 83.9 & 120 & 169 & 208 & 248 \\
\hline & Churdan & & & ${ }^{b_{\text {Lara }}}$ & 147 & 288 & 405 & 575 & 685 & 847 \\
\hline & & & & DB & 117 & 252 & 368 & 534 & 673 & 822 \\
\hline & & & & CG & -- & -- & -- & -- & -- & - \\
\hline 05482900 & Hardin Creek & 101 & 1951-93, & $17 \mathrm{~B}$ & 676 & 1,330 & 1,870 & 2,630 & 3,270 & 3,940 \\
\hline & near Farlin & & $1995-96$ & ${ }^{b_{\text {Lara }}}$ & 1,080 & 1,860 & 2,480 & 3,340 & 3,790 & 4,560 \\
\hline & & & & DB & 1,050 & 2,000 & 2,760 & 3,770 & 4,580 & 5,420 \\
\hline & & & & ${ }^{\mathrm{d}} \mathrm{CG}$ & 1,510 & 2,840 & 3,840 & 5,150 & 6,260 & 7,410 \\
\hline 05482950 & East Fork Hardin & 7.57 & $1952-55$ & $17 \mathrm{~B}$ & - & -. & -- & -- & -- & - \\
\hline & Creek near Paton & & & ${ }^{b}$ Lara & 147 & 288 & 404 & 574 & 685 & 846 \\
\hline & & & & DB & 115 & 258 & 385 & 568 & 725 & 894 \\
\hline & & & & $\mathrm{CG}$ & -- & -- & -- & -- & -- & - \\
\hline 05483000 & East Fork Hardin & 24.0 & $1952-91$ & $17 \mathrm{~B}$ & 230 & 365 & 456 & 570 & 654 & 737 \\
\hline & Creek near & & & $\mathrm{b}_{\text {Lara }}$ & 358 & 660 & 907 & 1,260 & 1,470 & 1,790 \\
\hline & Churdan & & & DB & 213 & 415 & 575 & 783 & 947 & 1,110 \\
\hline & & & & ${ }^{\mathrm{d}} \mathrm{CG}$ & 323 & 656 & 922 & 1,290 & 1,600 & 1,930 \\
\hline
\end{tabular}


Table 1. Floodflow frequencies for streamflow-gaging stations in the Raccoon River Basin--Continued

\begin{tabular}{|c|c|c|c|c|c|c|c|c|c|c|}
\hline \multirow{2}{*}{$\begin{array}{l}\text { Station } \\
\text { number } \\
\text { (fig. 1A) }\end{array}$} & \multirow[b]{2}{*}{ Station name } & \multirow{2}{*}{$\begin{array}{c}\text { Drain- } \\
\text { age area } \\
\left(\mathrm{mi}^{2}\right)\end{array}$} & \multirow{2}{*}{$\begin{array}{c}\text { Period of } \\
\text { flood record } \\
\text { a (water year) }\end{array}$} & \multirow[b]{2}{*}{ Method } & \multicolumn{6}{|c|}{$\begin{array}{l}\text { Discharge, in cubic feet per second, } \\
\text { for indicated recurrence interval, in years }\end{array}$} \\
\hline & & & & & 2 & 5 & 10 & 25 & 50 & 100 \\
\hline \multirow[t]{4}{*}{05483318} & \multirow{4}{*}{$\begin{array}{l}\text { Brushy Creek } \\
\text { near Templeton }\end{array}$} & \multirow[t]{4}{*}{45.0} & \multirow{4}{*}{$\begin{array}{l}1966-93, \\
1996\end{array}$} & $17 \mathrm{~B}$ & 2,280 & 4,200 & 5,800 & 8,240 & 10,400 & 12,700 \\
\hline & & & & ${ }^{\mathrm{e}}$ Lara & 1,370 & 2,500 & 3,340 & 4,500 & 5,430 & 6,400 \\
\hline & & & & DB & 1,440 & 2,890 & 4,100 & 5,790 & 7,200 & 8,710 \\
\hline & & & & $f, \mathrm{~g}_{\mathrm{CG}}$ & 1,430 & 2,780 & 3,880 & 5,460 & 6,760 & 8,130 \\
\hline \multirow[t]{4}{*}{05483343} & \multirow{4}{*}{$\begin{array}{l}\text { Hazelbrush } \\
\text { Creek near } \\
\text { Maple River }\end{array}$} & \multirow[t]{4}{*}{9.22} & \multirow[t]{4}{*}{$1991-94$} & 17B & -- & --- & -. & -- & -- & -- \\
\hline & & & & ${ }^{b}$ Lara & 171 & 332 & 464 & 657 & 780 & 962 \\
\hline & & & & DB & 696 & 1,500 & 2,210 & 3,260 & 4,170 & 5,160 \\
\hline & & & & CG & -- & - & -- & -- & -- & -- \\
\hline \multirow[t]{4}{*}{05483349} & \multirow{4}{*}{$\begin{array}{l}\text { Middle Raccoon } \\
\text { River tributary at } \\
\text { Carroll }\end{array}$} & \multirow[t]{4}{*}{6.58} & \multirow[t]{4}{*}{$1966-96$} & $17 \mathrm{~B}$ & 474 & 1,270 & 2,100 & 3,550 & 4,960 & 6,660 \\
\hline & & & & ${ }^{\mathrm{e}}$ Lara & 415 & 805 & 1,120 & 1,560 & 1,920 & 2,310 \\
\hline & & & & DB & 605 & 1,330 & 1,970 & 2,920 & 3,750 & 4,650 \\
\hline & & & & ${ }^{h} \mathrm{CG}$ & 386 & 890 & 1,340 & 2,070 & 2,680 & 3,440 \\
\hline \multirow[t]{4}{*}{05483450} & \multirow{4}{*}{$\begin{array}{l}\text { Middle Raccoon } \\
\text { River near } \\
\text { Bayard }\end{array}$} & \multirow[t]{4}{*}{375} & \multirow{4}{*}{$\begin{array}{l}1973, \\
1979-96\end{array}$} & $17 \mathrm{~B}$ & 3,550 & 6,690 & 9,340 & 13,300 & 16,800 & 20,600 \\
\hline & & & & 'Lara & 3,550 & 5,860 & 7,560 & 9,870 & 11,200 & 13,100 \\
\hline & & & & DB & 5,520 & 9,780 & 13,000 & 17,200 & 20,500 & 23,900 \\
\hline & & & & ${ }^{\mathrm{h}} \mathrm{CG}$ & 3,720 & 6,990 & 9,470 & 13,100 & 15,700 & 18,900 \\
\hline \multirow[t]{4}{*}{05483600} & \multirow{4}{*}{$\begin{array}{l}\text { Middle Raccoon } \\
\text { River at Panora }\end{array}$} & \multirow[t]{4}{*}{440} & 1953, & $\mathrm{j}_{17 \mathrm{~B}}$ & 4,850 & 8,380 & 11,100 & 14,900 & 17,900 & 21,200 \\
\hline & & & $1958-96$ & ${ }^{\mathrm{i}} \mathrm{Lara}$ & 3,960 & 6,480 & 8,340 & 10,900 & 12,300 & 14,400 \\
\hline & & & & DB & 5,690 & 10,000 & 13,300 & 17,500 & 20,800 & 24,200 \\
\hline & & & & CG & -- & -- & -- & -- & -- & -- \\
\hline 05484000 & South Raccoon & 994 & $1940-96$ & $17 \mathrm{~B}$ & 10,500 & 17,400 & 22,000 & 27,800 & 31,900 & 36,000 \\
\hline & River at Redfield & & & ${ }^{\mathrm{i}}$ Lara & 7,860 & 12,700 & 16,000 & 20,400 & 23,200 & 26,800 \\
\hline & & & & $\mathrm{DB}$ & 12,000 & 20,000 & 25,800 & 33,000 & 38,500 & 44,100 \\
\hline & & & & ${ }^{\mathrm{h}} \mathrm{CG}$ & 8,480 & 14,800 & 19,300 & 25,500 & 29,800 & 35,000 \\
\hline 05484500 & Raccoon River & 3,441 & $1915-96$ & $17 \mathrm{~B}$ & 14,500 & 24,000 & 30,800 & 40,000 & 47,200 & 54,500 \\
\hline & at Van Meter & & & 'Lara & 17,100 & 25,200 & 31,200 & 39,000 & 42,000 & 48,500 \\
\hline & & & & DB & -. & -- & -- & -- & - & -- \\
\hline & & & & ${ }^{\mathrm{d}} \mathrm{CG}$ & 10,600 & 17,900 & 23,000 & 29,000 & 34,200 & 39,200 \\
\hline 05484650 & Raccoon River & 3,529 & $1992-96$ & $17 \mathrm{~B}$ & -- & -- & -- & -- & -- & - \\
\hline & at 63rd Street, & & & iLara & 17,500 & 25,800 & 31,900 & 39,900 & 43,100 & 49,700 \\
\hline & Des Moines & & & DB & -. & -- & -- & - & - & - \\
\hline & & & & CG & -- & -- & -- & -- & -- & -- \\
\hline 05484800 & Walnut Creek at & 78.4 & $1972-96$ & $17 \mathrm{~B}$ & 2,260 & 4,670 & 6,810 & 10,100 & 13,100 & 16,400 \\
\hline & Des Moines & & & ${ }^{\mathrm{b}}$ Lara & 891 & 1,550 & 2,080 & 2,820 & 3,200 & 3,870 \\
\hline & & & & DB & 1,950 & 3,580 & 4,850 & 6,510 & 7,850 & 9,220 \\
\hline & & & & ${ }^{\mathrm{d}} \mathrm{CG}$ & 1,880 & 3,520 & 4,760 & 6,350 & 7,730 & 9,140 \\
\hline
\end{tabular}


Table 1. Floodflow frequencies for streamflow-gaging stations in the Raccoon River Basin--Continued

\begin{tabular}{|c|c|c|c|c|c|c|c|c|c|c|}
\hline \multirow{2}{*}{$\begin{array}{l}\text { Station } \\
\text { number } \\
\text { (fig. 1A) }\end{array}$} & \multirow[b]{2}{*}{ Station name } & \multirow{2}{*}{$\begin{array}{c}\text { Drain- } \\
\text { age area } \\
\left(\mathrm{mi}^{2}\right)\end{array}$} & \multirow{2}{*}{$\begin{array}{c}\text { Period of } \\
\text { flood record } \\
\text { a (water year) }\end{array}$} & \multirow[b]{2}{*}{ Method } & \multicolumn{6}{|c|}{$\begin{array}{l}\text { Discharge, in cubic feet per second, } \\
\text { for indicated recurrence interval, in years }\end{array}$} \\
\hline & & & & & 2 & 5 & 10 & 25 & 50 & 100 \\
\hline \multirow[t]{4}{*}{05484900} & \multirow{4}{*}{$\begin{array}{l}\text { Raccoon River } \\
\text { at Fleur Drive, } \\
\text { Des Moines }\end{array}$} & 3,625 & $1985-96$ & 17B & -- & -- & -- & -- & - & - \\
\hline & & & & ${ }^{\mathrm{i}}$ Lara & 17,800 & 26,300 & 32,500 & 40,600 & 43,800 & 50,500 \\
\hline & & & & DB & -- & -- & -- & - & -- & - \\
\hline & & & & CG & -- & -- & -- & -- & -- & -- \\
\hline
\end{tabular}

asee Appendix A for list of flood peaks.

${ }^{b}$ Flood-frequency equations for hydrologic region 4 were used.

${ }^{\mathrm{c}}$ Flood-frequency equations for region 2, active-channel were used.

${ }^{\mathrm{d}}$ Flood-frequency equations for region 2, bankfull were used.

eFlood-frequency equations for hydrologic region 3 were used.

${ }^{f}$ Flood-frequency equations for region 1 , active-channel were used.

Active-channel widths estimated from cross sections plotted from field-survey notes.

${ }^{\text {h }}$ Flood-frequency equations for region 1 , bankfull were used.

${ }^{i}$ Flood-frequency equations for hydrologic regions 3 and 4 were used based on weighted average, drainage-area ratios.

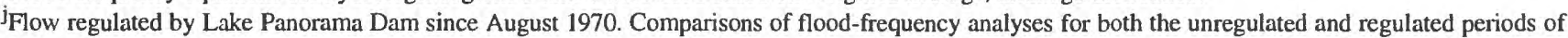
record for the Panora gage, and for a consecutive period of record for both the Bayard and Panora gages, indicates that the dam does not appear to significantly affect annual-peak discharges at the Panora gage. Flood frequency was computed using a combined unregulated and regulated period of record that included annual-peak discharges for water years 1953 and 1958-96.

report "Floods in the Raccoon River Basin, Iowa" (Heinitz, 1980). Water-surface-elevation profiles and peak discharges for the flood of June 29-July 1, 1986, in the Raccoon River Basin and for the flood of May 10, 1986, along Walnut Creek, and flood information collected through 1990 for streamflow-gaging stations in the Raccoon River Basin, are presented in the report "Floods of 1986 and 1990 in the Raccoon River Basin, West-Central Iowa" (Baebenroth and Schaap, 1992). Areas inundated in Des Moines and vicinity by the Raccoon River and Walnut Creek floods of 1993 are described in the hydrologic atlas "Delineation of Flooding within the Upper Mississippi River Basin-Flood of June 18 through August 4, 1993, in Des Moines and Vicinity, Iowa" (Schaap, 1996).

\section{Flood of June 1947}

Severe flooding that affected much of Iowa during June 1947 also involved west-central Iowa. Frequent rains and cool, cloudy weather during April and May saturated soils in the area prior to the flooding. Rainfall for June 1947, which averaged 10.33 in. statewide, is the second greatest statewide total for any month of record (surpassed only by the July 1993 statewide average of 10.50 in.) (Harry Hillaker, State Climatologist, Iowa Department of Agriculture and Land Stewardship, written commun., September 1993). The majority of the flooding in the Raccoon River Basin was caused by four successive thunderstorms over west-central Iowa during May 31-June 1, June 4-5, June 12-13, and June 22-23 (U.S. Department of Commerce, Weather Bureau, and Iowa Department of Agriculture, 1947a, p. 66-67, and 1947b, p. 84; Iowa Natural Resources Council, 1953, p. 37-43). Rainfall amounts recorded during the last three storms are listed below (U.S. Department of Commerce, Weather Bureau, and Iowa Department of Agriculture, 1947a, p. 68-69). The rain gage at Van Meter recorded 18.12 in. during June 1947, which at the time, was the maximum monthly amount of rainfall on record for the location.

\begin{tabular}{lccc}
\hline & \multicolumn{2}{c}{$\begin{array}{c}\text { Rainfall for the following days during } \\
\text { June 1947, in inches }\end{array}$} \\
\cline { 2 - 4 } \multicolumn{1}{c}{ Rain gage } & June 4-5 & June 12-13 & June 22-23 \\
\hline Carroll & 0.64 & 2.88 & 4.78 \\
Des Moines Airport & 3.77 & 5.48 & 1.24 \\
Guthrie Center & 1.20 & 3.40 & 0.12 \\
Jefferson & 1.68 & 2.91 & 0.07 \\
Lake City & 0.64 & 2.40 & 4.62 \\
Perry & 1.59 & 3.25 & 0.88 \\
Rockwell City & 0.53 & 2.14 & 6.65 \\
Sac City & 0.34 & 1.91 & 2.19 \\
Storm Lake & 0.24 & 1.50 & 0.68 \\
Van Meter & 5.00 & 5.92 & 3.07 \\
Waukee & 2.66 & 5.34 & 2.36 \\
\hline
\end{tabular}


Table 2. Selected flood-peak discharges, recurrence intervals, and unit runoff for streamflow-gaging stations in the Raccoon River Basin

[ft, foot; $\mathrm{ft}^{3} / \mathrm{s}$, cubic foot per second; $\left(\mathrm{ft}^{3} / \mathrm{s}\right) / \mathrm{mi}^{2}$, cubic foot per second per square mile; *, maximum flood-peak discharge known for site; --, not determined]

\begin{tabular}{|c|c|c|c|c|c|c|}
\hline $\begin{array}{l}\text { Station } \\
\text { number } \\
\text { (fig. 1A) }\end{array}$ & Station name & Date & $\begin{array}{l}\text { Gage height } \\
{ }^{a} \text { (ft) }\end{array}$ & $\begin{array}{c}\text { Discharge } \\
\left(\mathrm{ft}^{3} / \mathrm{s}\right)\end{array}$ & $\begin{array}{c}\text { Recurrence } \\
\text { interval } \\
\text { b(years) }\end{array}$ & $\begin{array}{l}\text { Unit runoff } \\
{\left[\left(\mathrm{ft}^{3} / \mathrm{s}\right) / \mathrm{mi}^{2}\right]}\end{array}$ \\
\hline \multirow[t]{3}{*}{05482135} & North Raccoon River near Newell & $06-17-84$ & 16.73 & $* 2,850$ & 9 & 12.2 \\
\hline & & $06-17-90$ & 16.33 & 2,380 & 5 & 10.2 \\
\hline & & $07-11-93$ & 16.20 & 2,420 & 5 & 10.4 \\
\hline \multirow[t]{3}{*}{05482170} & Big Cedar Creek near Varina & $08-31-62$ & 13.68 & $* 2,080$ & 17 & 26.0 \\
\hline & & 03-24-79 & $\mathrm{c}_{16.29}$ & $\mathrm{~d}_{2,050}$ & 16 & 25.6 \\
\hline & & $06-16-84$ & 12.77 & 1,710 & 9 & 21.4 \\
\hline \multirow[t]{4}{*}{05482300} & North Raccoon River near Sac City & $09-01-62$ & $\mathrm{e}_{18.12}$ & 10,800 & 12 & 15.4 \\
\hline & & 03-23-79 & $\mathrm{e}_{18.02}$ & $* 13,100$ & 25 & 18.7 \\
\hline & & $06-17-90$ & 20.14 & 9,930 & 10 & 14.2 \\
\hline & & $07-11-93$ & 17.55 & 6,550 & 4 & 9.36 \\
\hline \multirow[t]{6}{*}{05482500} & North Raccoon River near Jefferson & $06-23-47$ & 22.3 & $* 29,100$ & $\mathrm{f}_{1.0}$ & 18.0 \\
\hline & & $06-22-54$ & 19.52 & 21,300 & 25 & 13.2 \\
\hline & & $03-31-60$ & 19.43 & 18,600 & 15 & 11.5 \\
\hline & & $03-25-79$ & 17.84 & 15,300 & 8 & 9.45 \\
\hline & & $06-19-90$ & 18.61 & 18,400 & 14 & 11.4 \\
\hline & & $07-10-93$ & 19.20 & 16,900 & 11 & 10.4 \\
\hline \multirow[t]{4}{*}{05482600} & Hardin Creek at Farnhamville & $08-26-54$ & 10.48 & $* 2,000$ & 30 & 45.8 \\
\hline & & $07-26-69$ & 10.45 & 1,960 & 30 & 44.9 \\
\hline & & 03-19-79 & 10.29 & 1,850 & 25 & 42.3 \\
\hline & & $06-16-90$ & 10.39 . & 1,980 & 30 & 45.3 \\
\hline \multirow[t]{3}{*}{05482800} & Happy Run at Churdan & $03-25-62$ & 8.57 & 150 & 18 & 19.8 \\
\hline & & $06-13-67$ & 9.37 & $*{ }^{\mathrm{d}} 180$ & 30 & 23.7 \\
\hline & & 03-19-79 & 9.36 & ${ }^{* \mathrm{~d}} 180$ & 30 & 23.7 \\
\hline \multirow[t]{4}{*}{05482900} & Hardin Creek near Farlin & 03-19-79 & 12.69 & 2,330 & 18 & 23.1 \\
\hline & & $06-16-90$ & 12.89 & 2,470 & 20 & 24.5 \\
\hline & & $06-01-91$ & 13.02 & 2,630 & 25 & 26.0 \\
\hline & & $07-09-93$ & 13.97 & $* 3,010$ & 40 & 29.8 \\
\hline 05482950 & East Fork Hardin Creek near Paton & $03-24-53$ & 7.77 & $* 68$ & -- & 8.98 \\
\hline \multirow[t]{4}{*}{05483000} & East Fork Hardin Creek near Churdan & $05-05-60$ & 8.92 & 413 & 7 & 17.2 \\
\hline & & $03-19-79$ & 7.46 & 376 & 5 & 15.7 \\
\hline & & $06-30-86$ & $\mathrm{~g}_{10.78}$ & 737 & 100 & 30.7 \\
\hline & & $06-17-90$ & 10.20 & *754 & $\mathrm{f}_{1.0}$ & 31.4 \\
\hline \multirow[t]{3}{*}{05483318} & Brushy Creek near Templeton & $06-23-74$ & $h_{90.96}$ & 5,330 & 8 & 118 \\
\hline & & $06-16-90$ & $h_{90.58}$ & 7,550 & 20 & 168 \\
\hline & & $07-09-93$ & $h_{93.48}$ & $*{ }^{\mathrm{i}} 19,000$ & $\mathrm{f}_{1.5}$ & 422 \\
\hline 05483343 & Hazelbrush Creek near Maple River & $07-09-93$ & 14.77 & $* 1,120$ & -- & 121 \\
\hline
\end{tabular}


Table 2. Selected flood-peak discharges, recurrence intervals, and unit runoff for streamflow-gaging stations in the Raccoon River Basin--Continued

\begin{tabular}{|c|c|c|c|c|c|c|}
\hline $\begin{array}{l}\text { Station } \\
\text { number } \\
\text { (fig. 1A) }\end{array}$ & Station name & Date & $\begin{array}{l}\text { Gage height } \\
\text { a(ft) }\end{array}$ & $\begin{array}{c}\text { Discharge } \\
\left(\mathrm{ft}^{3} / \mathrm{s}\right)\end{array}$ & $\begin{array}{c}\text { Recurrence } \\
\text { interval } \\
\text { b (years) }\end{array}$ & $\begin{array}{l}\text { Unit runoff } \\
{\left[\left(\mathrm{ft}^{3} / \mathrm{s}\right) / \mathrm{mi}^{2}\right]}\end{array}$ \\
\hline \multirow[t]{3}{*}{05483349} & Middle Raccoon River tributary at Carroll & $06-29-86$ & 24.81 & 3,350 & 25 & 509 \\
\hline & & 07-09-93 & 25.79 & 4,490 & 40 & 682 \\
\hline & & $07-17-96$ & 25.88 & $* \mathrm{i} 4,600$ & 45 & 699 \\
\hline \multirow[t]{5}{*}{05483450} & Middle Raccoon River near Bayard & 07-03-73 & $\mathrm{g}_{21.63}$ & ${ }^{\mathrm{i}} 14,600$ & 35 & 38.9 \\
\hline & & 03-19-79 & $\mathrm{g}_{20.81}$ & 9,250 & 10 & 24.7 \\
\hline & & $06-30-86$ & 24.70 & 12,300 & 20 & 32.8 \\
\hline & & $06-17-90$ & 23.23 & 9,570 & 11 & 25.5 \\
\hline & & $07-09-93$ & 29.02 & $* 27,500$ & $\mathrm{f}_{1.3}$ & 73.3 \\
\hline \multirow[t]{7}{*}{05483600} & Middle Raccoon River at Panora & $06-10-53$ & $\mathrm{~g}_{14.3}$ & $\mathrm{~d}_{14,000}$ & 20 & 31.8 \\
\hline & & $07-02-58$ & 11.87 & 9,150 & 6 & 20.8 \\
\hline & & $05-19-74$ & 14.80 & 14,000 & 20 & 31.8 \\
\hline & & $03-19-79$ & 12.95 & 10,700 & 9 & 24.3 \\
\hline & & $06-30-86$ & 15.50 & 15,300 & 30 & 34.8 \\
\hline & & $06-18-90$ & 12.77 & 9,000 & 6 & 20.5 \\
\hline & & $07-09-93$ & 20.04 & $* 22,400$ & $\mathrm{f}_{1.1}$ & 50.9 \\
\hline \multirow[t]{6}{*}{05484000} & South Raccoon River at Redfield & $06-12-47$ & $\mathrm{j}_{24.3}$ & 23,800 & 14 & 23.9 \\
\hline & & $07-02-58$ & $\mathrm{~g}, j_{29.04}$ & 35,000 & 90 & 35.2 \\
\hline & & $03-19-79$ & $\mathrm{j}_{22.81}$ & 20,400 & 8 & 20.5 \\
\hline & & $07-01-86$ & $\mathrm{j}_{25.15}$ & 26,300 & 20 & 26.5 \\
\hline & & $06-16-90$ & 19.05 & 19,100 & 7 & 19.2 \\
\hline & & $07-10-93$ & 26.98 & $* 44,000$ & $\mathrm{f}_{1.2}$ & 44.3 \\
\hline \multirow[t]{6}{*}{05484500} & Raccoon River at Van Meter & $06-13-47$ & $\mathrm{~g}_{21.37}$ & 41,200 & 30 & 12.0 \\
\hline & & $07-03-58$ & 21.77 & 35,200 & 16 & 10.2 \\
\hline & & $03-19-79$ & 20.39 & 29,900 & 9 & 8.69 \\
\hline & & $07-01-86$ & 22.69 & 40,200 & 25 & 11.7 \\
\hline & & $06-16-90$ & 21.39 & 34,600 & 15 & 10.1 \\
\hline & & $07-10-93$ & 26.34 & $* 70,100$ & $\mathrm{f}_{1.3}$ & 20.4 \\
\hline 05484650 & Raccoon River at 63rd Street, Des Moines & $07-11-93$ & $\mathrm{~g}_{40.77}$ & - & -- & -- \\
\hline \multirow[t]{4}{*}{05484800} & Walnut Creek at Des Moines & $07-01-73$ & 17.72 & 9,000 & 19 & 115 \\
\hline & & $06-09-74$ & 17.44 & 8,160 & 15 & 104 \\
\hline & & $05-10-86$ & 18.32 & $* 12,500$ & 45 & 159 \\
\hline & & $06-16-90$ & 18.00 & 7,780 & 14 & 99.2 \\
\hline 05484900 & Raccoon River at Fleur Drive, Des Moines & $07-11-93$ & $\mathrm{~g}_{26.8}$ & -- & -. & - \\
\hline
\end{tabular}

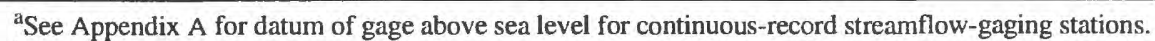

bInterpolated from Bulletin 17B flood-frequency analysis (Interagency Advisory Committee on Water Data, 1982) and rounded to the nearest 5 years for 20- to 50-year recurrence intervals and to the nearest 10 years above the 50 -year recurrence interval.

${ }^{c}$ Affected by ice.

${ }^{\mathrm{d}}$ Approximate.

${ }^{\text {e}}$ Prior to October 1, 1987, gaging station at different site and datum.

${ }^{\mathrm{f}}$ Recurrence interval discharge larger than the computed 100-year flood is expressed as a ratio of the given flood discharge to the 100-year flood discharge. ${ }^{g}$ Gage height determined from floodmarks.

${ }^{\mathrm{h}}$ Referenced to previous datum; datum was changed on July 17, 1996.

iDischarge computed from indirect measurement.

${ }^{\mathrm{j}}$ Prior to October 1, 1986, gaging station at different site and datum. 
During the first three weeks of June, the floods were confined to the lower portion of the Raccoon River Basin (U.S. Department of Commerce, Weather Bureau, and Iowa Department of Agriculture, 1947b, p. 85). Excessive rainfall on June 22nd in the upper portion of the basin resulted in flooding from north of Carroll to Des Moines. Additional information on the 1947 flood in the Raccoon River Basin can be found in the report

"An Inventory of Water Resources and Water Problems, Des Moines River Basin, Iowa" (Iowa Natural Resources Council, 1953, p. 37-43), which includes maps showing the areal distribution of rainfall and flood hydrographs for the periods June 4-6, June $12-13$, and June 17-23, 1947, for the Des Moines River Basin. As a result of the June 22-23 storm, the Raccoon and Des Moines Rivers crested almost simultaneously at Des Moines on June 26th and inundated nearly 7,000 acres or about one-fifth of the total area within the city limits (U.S. Department of Commerce, Weather Bureau, and Iowa Department of Agriculture, 1947a, p. 71). The flooding in Des Moines caused an estimated \$1.25 million of damage, the drowning of two people, and the evacuation of 800 families from their homes (U.S. Department of Commerce, Weather Bureau, and Iowa Department of Agriculture, 1947b, p. 86).

At the South Raccoon River at Redfield streamflow-gaging station, the peak discharge $\left(23,800 \mathrm{ft}^{3} / \mathrm{s}\right)$ for the flood of June 12, 1947 (table 2), is the fourth largest known at this site during 1940-96. The flood-peak discharge of $23,800 \mathrm{ft}^{3} / \mathrm{s}$ at the Redfield gage has a recurrence interval of approximately 14 years (table 2). At the Raccoon River at Van Meter gaging station, the peak discharge $\left(41,200 \mathrm{ft}^{3} / \mathrm{s}\right)$ for the flood of June 13, 1947 (table 2), is the second largest known and the peak stage $(21.37 \mathrm{ft})$ is the sixth largest known at this site during 1915-96. The flood-peak discharge of $41,200 \mathrm{ft}^{3} / \mathrm{s}$ at the Van Meter gage has a recurrence interval of approximately 30 years (table 2). At the North Raccoon River near Jefferson gaging station, the peak discharge $\left(29,100 \mathrm{ft}^{3} / \mathrm{s}\right)$ and stage $(22.3 \mathrm{ft})$ for the flood of June 23 , 1947 (table 2), are both the largest known at this site during 1940-96. The flood peak of $29,100 \mathrm{ft}^{3} / \mathrm{s}$ at the Jefferson gage has a recurrence interval of approximately 100 years (table 2). As a result of the June 22-23 storm, the Raccoon River at Van Meter crested again on June 25 th nearly as high as on June 13th, the peak discharge recorded on June 25,1947 , was $38,000 \mathrm{ft}^{3} / \mathrm{s}$ and the peak stage was $21.1 \mathrm{ft}$ (see Appendix A). At the Raccoon River at Van Meter gaging station, five separate flood crests occurred during June 1947 (see Appendix A) and the river was above flood stage during June 2-9, June 1219, and June 21-29. At the Des Moines Waterworks, on Fleur Drive in Des Moines (fig. 1B), flood crests on the Raccoon River of 19.8 and $19.5 \mathrm{ft}$ on June 13, and June 26, 1947, respectively, both exceeded the 1903 flood record (U.S. Department of Commerce, Weather Bureau, and Iowa Department of Agriculture, 1947b, p. 85).

\section{Flood of July 2-3, 1958}

The flood of July 2-3, 1958, occurred as a result of an intense localized thunderstorm on July 2 nd in the lower part of the Raccoon River Basin, primarily in the South Raccoon River Basin. Rainfall amounts recorded on July 2-3, 1958, are listed below (U.S. Department of Commerce and Weather Bureau, data obtained through the Midwestern Climate Center Web site). The rain gage at Guthrie Center recorded 6.55 in. on July 2 nd.

\begin{tabular}{lcll}
\hline \multicolumn{4}{c}{ Rain gage and rainfall for July 2-3, 1958, in inches } \\
\hline Carroll & 1.35 & Perry & 5.01 \\
Des Moines Airport & 3.93 & Rockwell City & 1.52 \\
Guthrie Center & 6.59 & Sac City & 1.33 \\
Jefferson & 2.74 & Storm Lake & 0.11 \\
\hline
\end{tabular}

At the South Raccoon River at Redfield streamflow-gaging station, the peak discharge $\left(35,000 \mathrm{ft}^{3} / \mathrm{s}\right)$ for the flood of July 2, 1958 (table 2), is the second largest known at this site during 1940-96. The flood-peak discharge of $35,000 \mathrm{ft}^{3} / \mathrm{s}$ at the Redfield gage has a recurrence interval of approximately 90 years (table 2). At the Raccoon River at Van Meter gaging station, the peak discharge $\left(35,200 \mathrm{ft}^{3} / \mathrm{s}\right)$ for the flood of July 3,1958 (table 2), is the sixth largest known and the peak stage $(21.77 \mathrm{ft})$ is the third largest known at this site during 1915-96. The flood-peak discharge of $35,200 \mathrm{ft}^{3} / \mathrm{s}$ at the Van Meter gage has a recurrence interval of approximately 16 years (table 2 ).

\section{Flood of March 19-25, 1979}

The flood of March 19-25, 1979, in the Raccoon River Basin resulted from a rapid snowmelt that occurred over a period of several days prior to the flooding, in combination with rainfall and snowfall. Snow depths for March 16, rainfall amounts for March 18-19 
and 22-24, and snowfall amounts for March 23, 1979 , are listed below (U.S. Department of Commerce, National Oceanic and Atmospheric Administration, and Iowa Department of Agriculture, 1979, p. 5-13).

\begin{tabular}{|c|c|c|c|c|}
\hline Rain gage & $\begin{array}{c}\text { Snow on } \\
\text { ground } \\
\text { on } \\
\text { March 16, } \\
1979, \\
\text { in inches }\end{array}$ & $\begin{array}{c}\text { Rainfall } \\
\text { for } \\
\text { March 18- } \\
19,1979 \text {, } \\
\text { in inches }\end{array}$ & $\begin{array}{c}\text { Rainfall } \\
\text { for } \\
\text { March 22- } \\
24,1979 \text {, } \\
\text { in inches }\end{array}$ & $\begin{array}{c}\text { Snowfall } \\
\text { for } \\
\text { March 23, } \\
1979, \\
\text { in inches }\end{array}$ \\
\hline Carroll & -- & 0.87 & 1.16 & -- \\
\hline Des Moines Airport & 0 & 0.88 & 1.43 & 3.6 \\
\hline Guthrie Center & -- & 1.84 & 0.91 & -- \\
\hline Jefferson & 5 & 1.90 & 0.82 & 2.0 \\
\hline Perry & - & 1.36 & 0.53 & - \\
\hline Rockwell City & 16 & 0.69 & 1.01 & 2.5 \\
\hline Sac City & -- & 1.02 & 2.82 & -- \\
\hline Storm Lake & 22 & 0.67 & 1.87 & 0.5 \\
\hline
\end{tabular}

-- , not determined

At the Big Cedar Creek near Varina streamflowgaging station, the peak discharge $\left(2,050 \mathrm{ft}^{3} / \mathrm{s}\right)$ for the flood of March 24, 1979 (table 2), is the second largest known at this site during 1960-91. The flood-peak discharge of $2,050 \mathrm{ft}^{3} / \mathrm{s}$ at the Varina gage has a recurrence interval of approximately 16 years (table 2). At the North Raccoon River near Sac City gaging station, the peak discharge $\left(13,100 \mathrm{ft}^{3} / \mathrm{s}\right)$ for the flood of March 23, 1979 (table 2), is the largest known at this site during 1954 and 1958-96. The flood-peak discharge of $13,100 \mathrm{ft}^{3} / \mathrm{s}$ at the Sac City gage has a recurrence interval of approximately 25 years (table 2).

\section{Floods of May 10, and June 29-July 1, 1986}

The May 10, 1986, flood in the Walnut Creek Basin resulted from a localized thunderstorm that occurred during the evening of May 9th. Intense rainfall ranging from 4 to 7 in. was reported in the Walnut Creek Basin. At Waukee, 6.09 in. of rain fell in about 2.5 hours (U.S. Department of Commerce, National Oceanic and Atmospheric Administration, and Iowa Department of Agriculture and Land Stewardship, 1986a). A flash flood occurred on Walnut Creek in the early-morning hours of May 10th. As a result of the flood, damage to homes and businesses along Walnut Creek was reported to be in the millions of dollars (U.S. Department of Commerce, National Oceanic and Atmospheric Administration, and
National Weather Service, Storm summary report, 1986, p. 5). Rainfall amounts recorded during May 9-10, 1986, are listed below (U.S. Department of Commerce and National Oceanic and Atmospheric Administration, data obtained through the Midwestern Climate Center Web site).

\begin{tabular}{llll}
\hline \multicolumn{4}{c}{ Rain gage and rainfall for May 9-10, 1986, in inches } \\
\hline Carroll & 2.06 & Perry & 2.22 \\
Des Moines Airport & 0.80 & Rockwell City & 2.27 \\
Guthrie Center & 3.62 & Sac City & 2.35 \\
Jefferson & 1.10 & Storm Lake & 1.68 \\
\hline
\end{tabular}

At the Walnut Creek at Des Moines streamflowgaging station, the peak discharge $\left(12,500 \mathrm{ft}^{3} / \mathrm{s}\right)$ and stage (18.32 ft) for the flood of May 10, 1986 (table 2), are both the largest known at this site during 1972-96. At the Walnut Creek gage, the flood-peak discharge of $12,500 \mathrm{ft}^{3} / \mathrm{s}$ has a recurrence interval of approximately 45 years (table 2) and the peak stage of $18.32 \mathrm{ft}$ exceeded the flood stage by about $5.3 \mathrm{ft}$.

The flood of June 29-July 1, 1986, occurred as a result of excessive rainfall over the middle and lower portions of the Raccoon River Basin during June 28-30th. Rainfall amounts of 8 to $12 \mathrm{in}$. were reported for central and north-central Iowa during June 28-30th, primarily in the Middle Raccoon River Basin (U.S. Department of Commerce, National Oceanic and Atmospheric Administration, and Iowa Department of Agriculture and Land Stewardship, 1986b). Rainfall amounts recorded during June 28-30, 1986, are listed below (U.S. Department of Commerce and National Oceanic and Atmospheric Administration, data obtained through the Midwestern Climate Center Web site).

\begin{tabular}{llll}
\hline \multicolumn{4}{c}{ Rain gage and rainfall for June 28-30, 1986, in inches } \\
\hline Carroll & 2.97 & Perry & 6.23 \\
Des Moines Airport & 3.64 & Rockwell City & 1.47 \\
Guthrie Center & 3.77 & Sac City & 1.23 \\
Jefferson & 6.43 & Storm Lake & 1.07 \\
\hline
\end{tabular}

At the East Fork Hardin Creek near Churdan gaging station, the peak discharge $\left(737 \mathrm{ft}^{3} / \mathrm{s}\right)$ for the flood of June 30, 1986 (table 2), is the second largest known at this site during 1952-91. The flood-peak discharge of $737 \mathrm{ft}^{3} / \mathrm{s}$ at the Churdan gage has a recurrence interval of approximately 100 years (table 2). At the Middle Rac- 
coon River near Bayard gaging station, the peak discharge $\left(12,300 \mathrm{ft}^{3} / \mathrm{s}\right)$ for the flood of June 30,1986 (table 2), is the third largest known and the peak stage ( $24.70 \mathrm{ft}$ ) is the second largest known at this site during 1973 and 1979-96. The flood-peak discharge of $12,300 \mathrm{ft}^{3} / \mathrm{s}$ at the Bayard gage has a recurrence interval of approximately 20 years (table 2). At the Middle Raccoon River at Panora gaging station, the peak discharge $\left(15,300 \mathrm{ft}^{3} / \mathrm{s}\right)$ and stage $(15.50 \mathrm{ft})$ for the flood of June 30 , 1986 (table 2), are both the second largest recorded at this site during 1953 and 1958-96. The flood-peak discharge of $15,300 \mathrm{ft}^{3} / \mathrm{s}$ at the Panora gage has a recurrence interval of approximately 30 years (table 2). At the South Raccoon River at Redfield gaging station, the peak discharge $\left(26,300 \mathrm{ft}^{3} / \mathrm{s}\right)$ for the flood of July 1,1986 (table 2 ), is the third largest known at this site during 1940-96. The flood-peak discharge of $26,300 \mathrm{ft}^{3} / \mathrm{s}$ at the Redfield gage has a recurrence interval of approximately 20 years (table 2). At the Raccoon River at Van Meter gaging station, the peak discharge $\left(40,200 \mathrm{ft}^{3} / \mathrm{s}\right)$ for the flood of July 1, 1986 (table 2), is the third largest known and the peak stage $(22.69 \mathrm{ft})$ is the second largest known at this site during 1915-96. The flood-peak discharge of $40,200 \mathrm{ft}^{3} / \mathrm{s}$ at the Van Meter gage has a recurrence interval of approximately 25 years (table 2 ).

\section{Flood of June 16-19, 1990}

Following a wet spring with excessive precipitation in both March and May, persistent and widespread rainfall occurred throughout the State in June of 1990. On average, 8.02 in. of rain fell over the State, making it the fourth wettest June in the 118 years of state records available at the time (U.S. Department of Commerce, National Oceanic and Atmospheric Administration, and Iowa Department of Agriculture and Land Stewardship, 1990 , p. 31-32). Intense thunderstorms that began on June 13th, over antecedent wet soil conditions, resulted in flooding across much of central and east-central Iowa. The majority of the flooding occurred as a result of excessive rainfall during June 16-17th. Nearly 6 in. of rain fell at Van Meter in a little over two hours on June 16th (U.S. Department of Commerce, National Oceanic and Atmospheric Administration, and National Weather Service, Storm summary report, 1990 , p. 10). Rainfall amounts recorded during June 16-17, 1990, are listed below (U.S. Department of Commerce, National Oceanic and Atmospheric Administration, and Iowa Department of Agriculture and Land Stewardship, 1990, p. 6-7).

\begin{tabular}{lclc}
\hline \multicolumn{4}{c}{ Rain gage and rainfall for June 16-17, 1990, in inches } \\
\hline Carroll & 2.40 & Perry & 3.44 \\
Des Moines Airport & 4.54 & Rockwell City & 1.97 \\
Guthrie Center & 3.45 & Sac City & 2.78 \\
Jefferson & 2.71 & Storm Lake & 4.19 \\
\hline
\end{tabular}

The intense rainfall caused flash flooding on Walnut Creek in Des Moines. Flooding along Walnut Creek closed streets in a broad area of West Des Moines, from Grand Avenue south to the Raccoon River and from 14th Street in West Des Moines to 59th Street in Des Moines; flooding along the Raccoon River in Des Moines closed Fleur Drive from Bell Avenue to Locust Street (fig. 1B) (Des Moines Register, June 17, 1990). In Des Moines and West Des Moines, more than 1,200 homes were affected by the flooding (Doug Riggs, Red Cross spokesperson, Des Moines Register, June 18, 1990). Agricultural damage, including soil erosion, was extensive as a result of the flooding. In Dallas County, approximately one-half of the county or about 175,000 acres were affected by severe soil erosion and flooding (Beth Grabau, Dallas County Executive Director, Agricultural Stabilization and Conservation Service, Des Moines Register June 20, 1990). The U.S. Soil Conservation Service reported that soil erosion resulting from the June 1619th storms equalled or exceeded 20 tons per acre on nearly 2.8 million acres of cropland in central and eastern Iowa, including all of Carroll, Dallas, Greene, Guthrie, and Polk Counties; the erosion rate exceeded 40 tons per acre on 350,000 acres of the total affected area (Des Moines Register, June 22, 1990). As a result of the widespread flooding during June 1990, 44 of Iowa's 99 counties received State disaster declarations, with 33 of these counties receiving Federal disaster designations. Flood damage eligible under Presidential and Secretarial Declarations for the period May 18 to July 6, 1990, that includes public, residential, small business, and agricultural damage, exceeded $\$ 14.1$ million for the 10-county area of Buena Vista, Calhoun, Carroll, Dallas, Greene, Guthrie, Pocahontas, Polk, Sac, and Webster Counties (information provided by Ellen Gordon, Disaster Services Division, Iowa Department of Public Defense, written commun., April 1991).

At the East Fork Hardin Creek near Churdan streamflow-gaging station, the peak discharge $\left(754 \mathrm{ft}^{3} / \mathrm{s}\right)$ for the flood of June 17, 1990 (table 2), is the largest known at this site during 1952-91. The flood-peak discharge of $754 \mathrm{ft}^{3} / \mathrm{s}$ at the Churdan gage has a recurrence interval of approximately 100 years (table 2 ). At the Rac- 
coon River at Van Meter gaging station, the peak discharge $\left(34,600 \mathrm{ft}^{3} / \mathrm{s}\right)$ for the flood of June 16,1990 (table 2), is the eighth largest known and the peak stage (21.39 $\mathrm{ft}$ ) is the fifth largest known at this site during 1915-96. The flood-peak discharge of $34,600 \mathrm{ft}^{3} / \mathrm{s}$ at the Van Meter gage has a recurrence interval of approximately 15 years (table 2). At the Walnut Creek at Des Moines gaging station, the peak discharge $\left(7,780 \mathrm{ft}^{3} / \mathrm{s}\right)$ for the flood of June 16, 1990 (table 2), is the fourth largest known and the peak stage ( $18.00 \mathrm{ft})$ is the second largest known at this site during 1972-96. At the Walnut Creek gage, the flood-peak discharge of $7,780 \mathrm{ft}^{3} / \mathrm{s}$ has a recurrence interval of approximately 14 years (table 2) and the peak stage of $18.00 \mathrm{ft}$ exceeded the flood stage by about $5.0 \mathrm{ft}$.

\section{Flood of July 9-11, 1993}

The largest flood on record in the Raccoon River Basin occurred during July 9-11, 1993. From mid-June through early August 1993, severe flooding in a ninestate area of the upper Mississippi River Basin followed an extended period of persistent precipitation that began in January. Following a spring that was wetter than average, weather patterns that persisted from early June through July caused the upper Midwest to be deluged with an excessive amount of rainfall (Wahl and others, 1993, p. 1). The 1993 flood in the upper Midwest is significant with respect to the magnitude and duration of flow. Flood-peak discharges that equalled or exceeded the 10-year recurrence interval were recorded at 154 streamflow-gaging stations in the flooded region during June through August 1993 (Parrett and others, 1993, p. 9-14). Not only were previous maximum peak discharges exceeded at many gaging stations, but flood volumes were significantly higher than previous maximums (Southard, 1995, p. 1). The human and economic costs of the flood were high. Total flood and other related damage in the upper Mississippi River Basin was estimated in the $\$ 10$ billion to $\$ 16$ billion range, with total Federal expenditures in excess of $\$ 5.4$ billion (Scientific Assessment and Strategy Team, 1994, p. 191).

In Iowa, thirty-four streamflow-gaging stations exceeded previous peak discharges in 1993 with the vast majority of peaks occurring in July (Southard and others, 1994, p. 7). Eleven gaging stations in Iowa with 10 or more years of record on unregulated streams had flood recurrence intervals of 100 years or greater and every major reservoir in the State had record pool elevations.
As a result of the magnitude of the 1993 flood, computed flood-frequency discharges increased at the majority of streamflow-gaging stations in Iowa, including the majority of those in the Raccoon River Basin (Eash, in press). Damage from the 1993 flood in Iowa was estimated to exceed $\$ 3.2$ billion (Jerry Ostendorf, Iowa Emergency Management Division, written commun., March 1994).

The majority of the following information pertaining to precipitation for the July 9-11, 1993, flood was provided by Harry Hillaker (State Climatologist, Iowa Department of Agriculture and Land Stewardship, written commun., September, 1993; Iowa Department of Agriculture and Land Stewardship, 1993, p. 1; U.S. Department of Commerce, National Oceanic and Atmospheric Administration, and Iowa Department of Agriculture and Land Stewardship, 1993, p. 35-36). The 1993 flood is the most severe natural disaster in Iowa history; flooding struck virtually every county of the State. Only the flood of 1851 , which occurred five years after Iowa statehood, appears to be possibly of similar magnitude statewide to the flood of 1993. However, incomplete quantitative historical records make comparison of the two flood years impossible. On average, $10.50 \mathrm{in}$. of rain fell over the State during July 1993, making it the wettest month ever recorded in Iowa in 121 years of record (1873-1993). The flood of July 9-11, 1993 , in west-central Iowa occurred as a result of intense thunderstorms over the area during July 8-9, 1993 (fig. 2). Strong thunderstorms moved into west-central Iowa before sunrise on July 8th and rapidly traversed eastward across the state into Illinois by noon. A second set of stronger thunderstorms developed over westcentral Iowa later in the afternoon of July 8 th and they slowly moved along the same path as the morning storms. By the time these storms weakened around sunrise on July 9th, a wide area of 3-9 in. of rain fell in an uninterrupted 275-mi long band across the state (see inset map on fig. 2). The greatest rainfall amounts were concentrated in west-central Iowa where rainfall ranging from 3 to more than $7 \mathrm{in}$. was common over the middle portion of the Raccoon River Basin (fig 2.) The greatest rainfall was centered over Carroll and Greene Counties and over northern Guthrie County in the headwaters of Brushy Creek (tributary to the South Raccoon River) and in the middle reaches of the North Raccoon and Middle Raccoon Rivers. Unofficial rainfall amounts of nearly 12 in. were reported in some parts of Carroll County (Des Moines Register, July 10, 1993). Official rainfall amounts recorded during July 8-9, 1993, are 


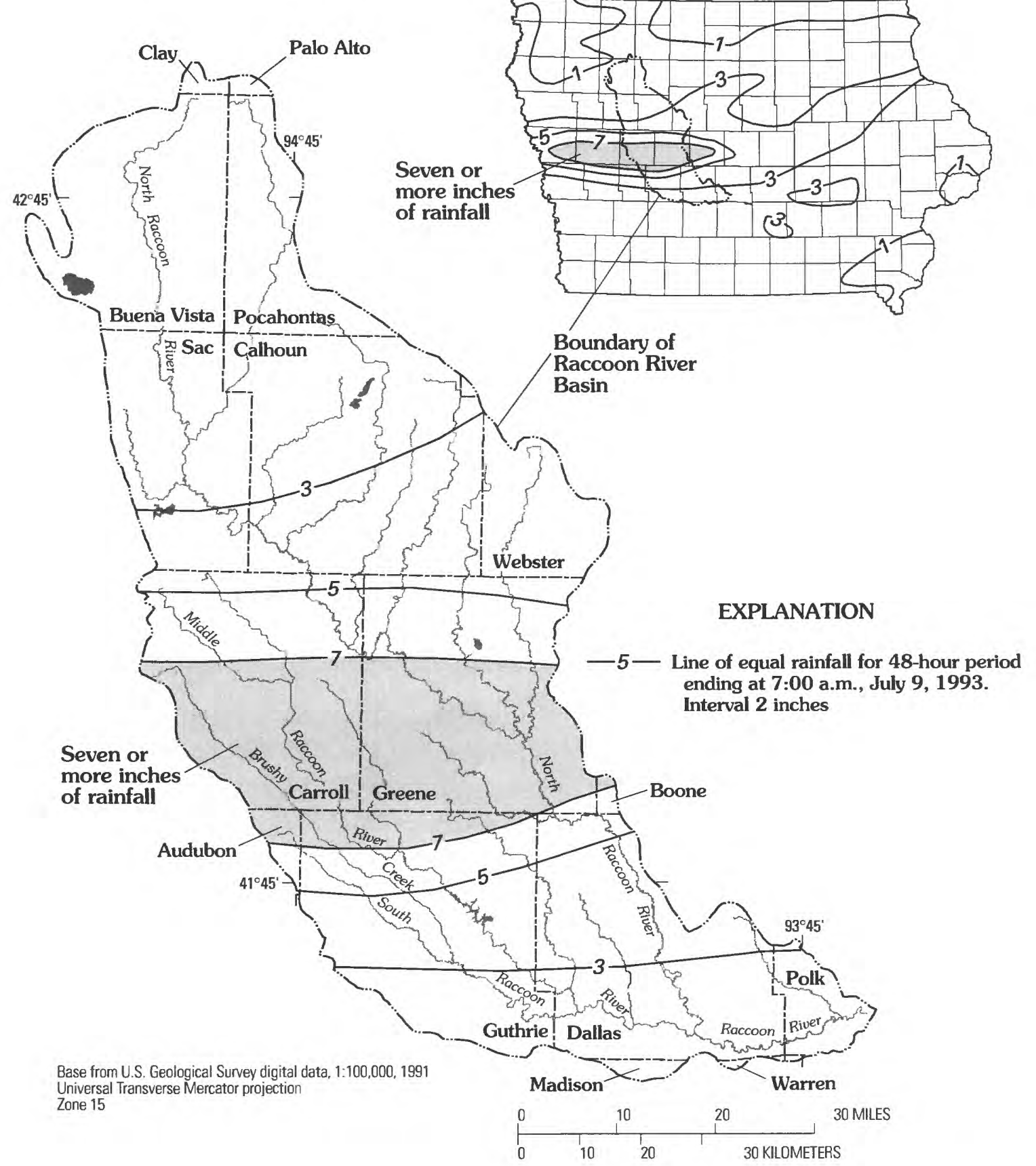

Figure 2. Areal distribution of rainfall for the July8-9, 1993, storm in the Raccoon River Basin and in lowa (lines of equal rainfall, in inches, provided by Harry Hillaker, State Climatologist, lowa Department of Agriculture and Land Stewardship, Written Commun., September 1993). 
listed below (U.S. Department of Commerce, National Oceanic and Atmospheric Administration, and Iowa Department of Agriculture and Land Stewardship, 1993, p. 6-7).

\begin{tabular}{lclc}
\hline \multicolumn{4}{c}{ Rain gage and rainfall for July 8-9, 1993, in inches } \\
\hline Carroll & 9.45 & Perry & 3.30 \\
Des Moines Airport & 1.26 & Rockwell City & 2.63 \\
Guthrie Center & 3.00 & Sac City & 1.77 \\
Jefferson & 8.56 & Storm Lake & 1.64 \\
\hline
\end{tabular}

A total of 7.40 in. of rain fell at Coon Rapids between 5:00 a.m. on July 8 and 4:00 a.m. on July 9, 1993 (fig. 3) (U.S. Department of Commerce and National Oceanic and Atmospheric Administration, 1993 , p. 7). The majority of the rain (6.30 in.) fell between 7:00 and 12:00 p.m. on July 8th; the average rainfall intensity during this 5 -hour period was approximately 1.3 in. per hour. The maximum intensity was 2.5 in. in one hour, which occurred between 7:00 and 8:00 p.m. Twenty-four hour rainfall amounts of 7.40 in. at Coon Rapids and 6.87 in. at Carroll were recorded during July 8-9, 1993; both exceeded the 100-year, 24-hour recurrence-interval rainfall amounts for each area of 6.65 and 6.55 in., respectively (Waite, 1988, p. 34). Runoff from the storm resulted in a catastrophic flood along the Raccoon River. Discharge in the Raccoon River at the Van Meter gaging station tripled (increasing from $23,500 \mathrm{ft}^{3} / \mathrm{s}$ to $70,100 \mathrm{ft}^{3} / \mathrm{s}$ ) in the 24-hour period ending at 2 p.m. on July 10th (fig. 4).

The following information in this paragraph was obtained from the Des Moines Register (July 11 and 12, 1993, newspaper articles). In West Des Moines, a sandbag levee built along Railroad Avenue (fig. 1B) by hundreds of volunteers and National Guard troops was unable to contain floodwaters of the Raccoon River that were rising nearly a foot every hour; on the evening of July 10th, a break occurred in the West Des Moines levee and floodwaters from the Raccoon River inundated parts of the historic Valley Junction business district (fig. 1B) under more than $5 \mathrm{ft}$ of water. The order to evacuate the Valley Junction area was issued at 8 p.m. At another location a few blocks to the west along Railroad Avenue, 1,000 volunteers built a sandbag levee along the West Des Moines Water Works that successfully protected the water supply for that city during the flood (fig. 1B). At 1 a.m. on July 11th, the Raccoon River flooded the Water Works for the City of Des Moines (fig. 1B), an installation protected by a levee built $6 \mathrm{ft}$ higher than the highest, previously known flood. Because of the inundation of the water treatment plant, water service was cut-off to more than 250,000 Des Moines area residents for 19 days. The Des Moines Fire Department was without water to fight major fires. During the interruption in water service, truckloads of potable water and water suitable for other purposes, such as washing, were hauled to Des Moines and waterdistribution centers were established at 29 area grocery stores. The Raccoon River floodwaters combined with a record crest on the Des Moines River inundated several electrical substations, resulting in the loss of power to many areas of Des Moines, including all of the downtown area. As reported in the Des Moines Register newspaper on Monday July 12, 1993:

"The unprecedented extent of flooding and the magnitude of the damage left no area of central lowa unaffected. Traffic was paralyzed, commerce was reduced to a standstill and basements were flooded. The most basic of human tasks were rendered impossible. For most residents of central lowa, life Sunday boiled down to two goals: finding safe water and regaining electrical service."

During the flood, officials released water out of Lake Panorama (fig. 1A) on July 10th, according to normal operating procedures, to maintain lake elevation. It was uncertain what effect the release from Lake Panorama had on the rising Raccoon River. Outflow to the Des Moines River from the Saylorville Reservoir (fig. 1A) was increased during July 9-10, according to the prescribed regulation plan. Officials did not believe the increase in outflow from the Saylorville Reservoir affected the Des Moines Water Works (Des Moines Register, July 18, 1993). Flooding on the Raccoon and Des Moines Rivers forced the evacuation of about 5,000 residents in Des Moines and West Des Moines; both cities declared states of emergency (Des Moines Register, July 11, 1993). Numerous streets in Des Moines and West Des Moines were closed as a result of the flood, including Fleur Drive between Park Avenue and Locust Street, S.W. 30th Street between Valley Drive and Bell Avenue, Thomas Beck Road between S.W. 9th Street and Fleur Drive, Valley Drive between Park Avenue and S.W. 28th Street, and West Riverside Drive between Court Avenue and S.W. 1st Street (fig. 1B) (Des Moines Register, July 11, 1993). Des Moines officials estimated flood damage to the city and its residents exceeded $\$ 253$ million (Des Moines Register, July 14, 1993). A case study describing the flood 


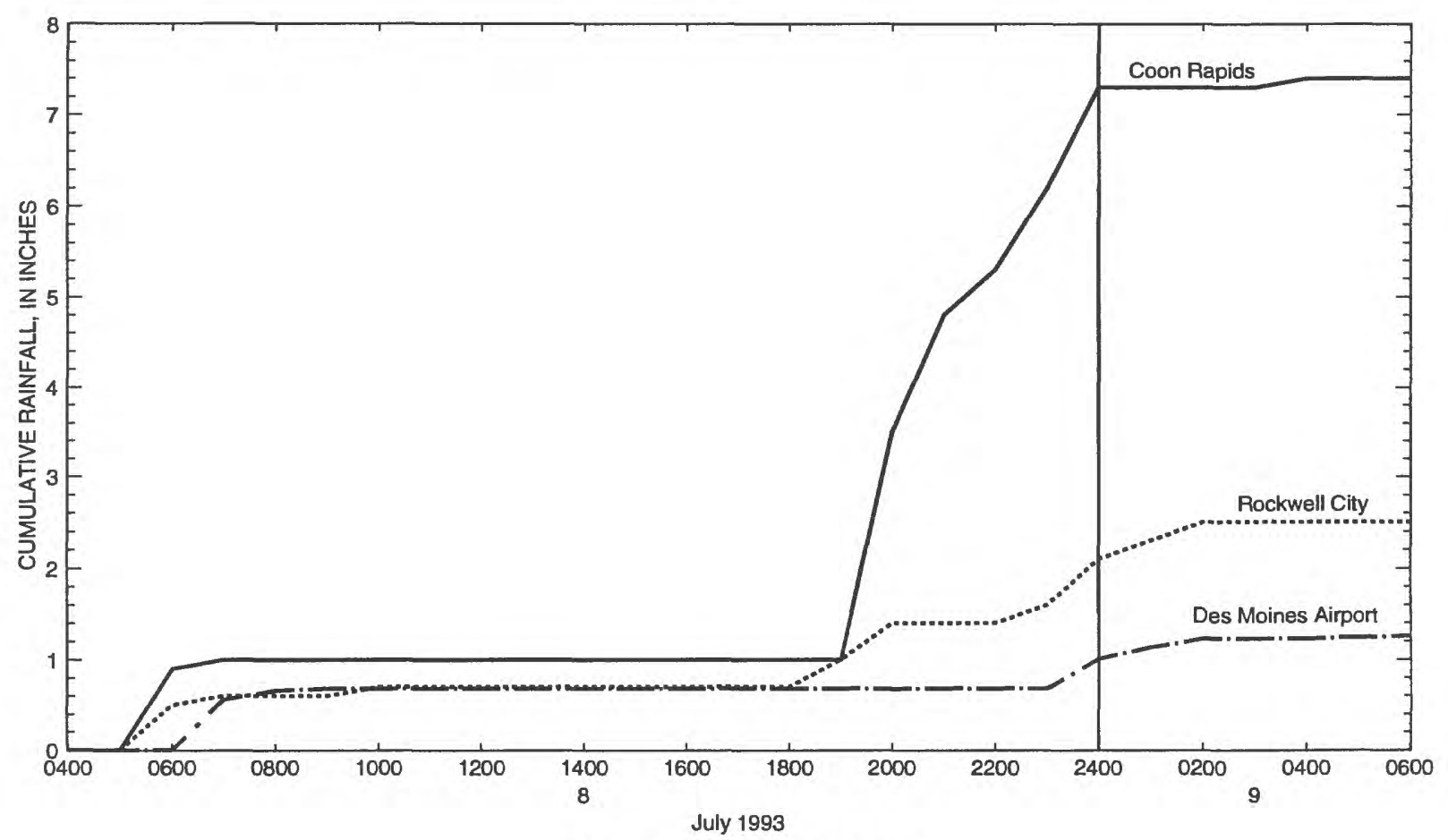

TIME, IN HOURS SINCE MIDNIGHT

Figure 3. Cumulative rainfall for July 8-9, 1993, at Coon Rapids, the Des Moines Airport, and Rockwell City, lowa (U.S. Department of Commerce and National Oceanic and Atmospheric Administration, 1993, p. 7).

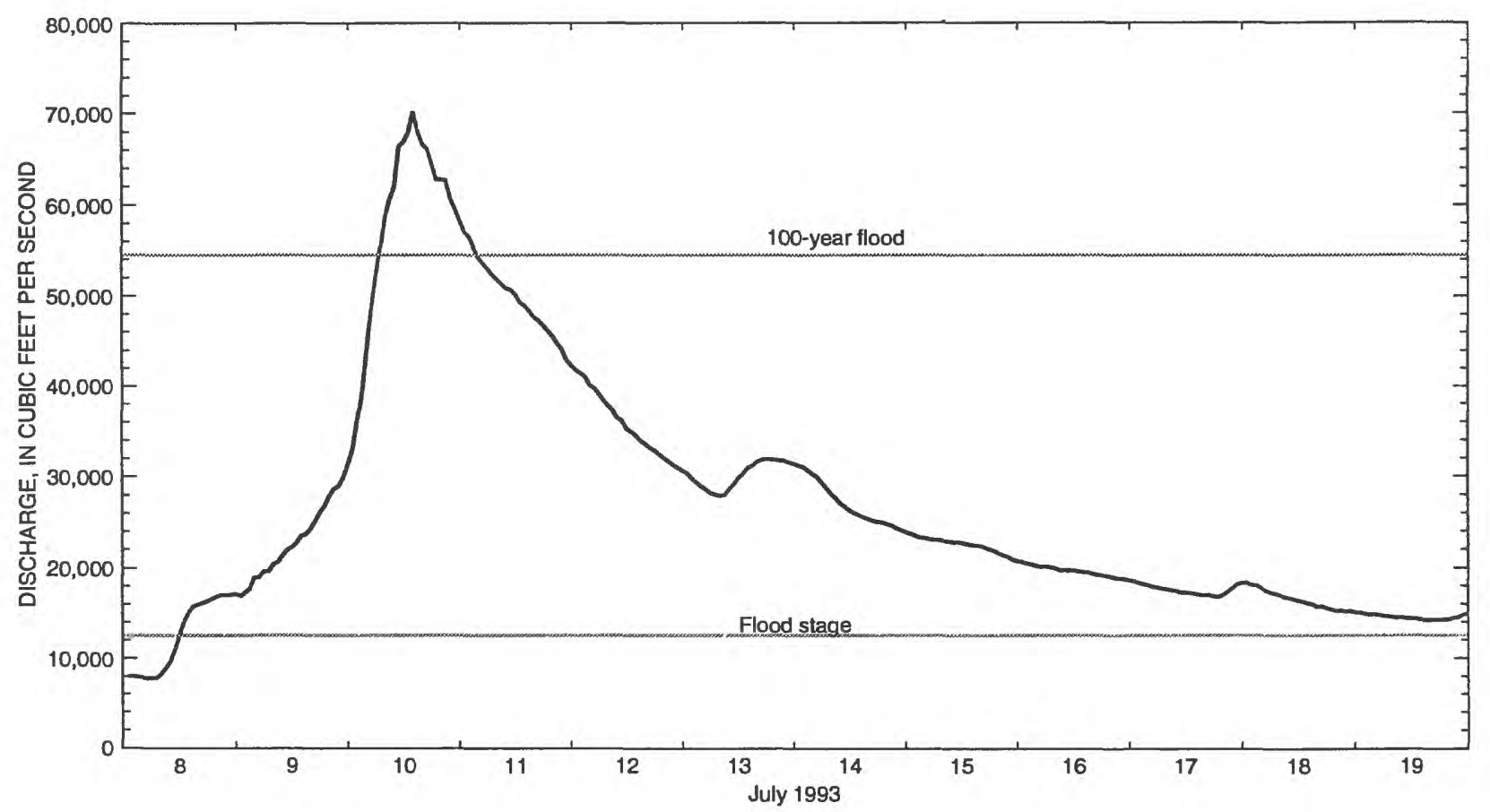

Figure 4. Discharge at the Raccoon River at Van Meter streamflow-gaging station (station number 05484500) July 8 through July 19, 1993. 
modeling and forecasting response to the July 8-9, 1993, rainfall in the Raccoon River Basin, and the hydrometeorological complexity of the rainfall and runoff events that lead up to the flooding in Des Moines during July $10-12,1993$, is presented in the report "The Great Flood of 1993" (U.S. Department of Commerce and National Oceanic and Atmospheric Administration, 1994, p. 6-27--6-38).

Flooding in the Raccoon River Basin caused many road closures including both the eastbound and westbound lanes of Interstate 80 from west of the Adel exit to the Waukee exit, Interstate 35 from the Interstates 80 and 235 interchange south to the U.S. Highway 34-Osceola interchange, U.S. Highway 71 between Carroll and State Highway 141, State Highway 4 north of State Highway 141 near Jamaica, and State Highway 141 west of Coon Rapids (fig. 1A) (Des Moines Register, July 11, 1993). The record flood on Brushy Creek caused the scour and failure of the U.S. Highway 71 bridge crossing Brushy Creek (site of gaging station Brushy Creek near Templeton, station number 05483318, fig. 1A) (Monk, 1995, p. 38-46). As a result of the 1993 flood, all 99 counties in Iowa were declared Federal disaster areas. Flood damage eligible under the Public Assistance Program of the Federal Emergency Management Agency for flooding that occurred from April 13 to October 1, 1993, that does not include residential and agricultural damage, exceeded $\$ 23.9$ million for the 5-county area of Carroll, Dallas, Greene, Guthrie, and Polk Counties (information provided by Jerry Ostendorf, Iowa Emergency Management Division, written commun., April 1997).

The peak discharge and stage for the flood of July 9-11, 1993, are both the largest known at the Brushy Creek near Templeton streamflow-gaging station during 1966-93 and 1996, at the Middle Raccoon River near Bayard gaging station during 1973 and 1979-96, at the Middle Raccoon River at Panora gaging station during 1953 and 1958-96, and at the Raccoon River at Van Meter gaging station during 1915-96 (table 2). At the South Raccoon River at Redfield gaging station, the peak discharge for the flood of July 10 , 1993 (table 2), is the largest known at this site during 1940-96. At the Brushy Creek near Templeton gaging station, the July 9, 1993, flood-peak discharge of $19,000 \mathrm{ft}^{3} / \mathrm{s}$ is 1.5 times larger than the 100 -year recurrence-interval discharge (table 2). At the Middle Raccoon River near Bayard gaging station, the July 9 , 1993, flood-peak discharge of $27,500 \mathrm{ft}^{3} / \mathrm{s}$ is 1.3 times larger than the 100-year recurrence-interval discharge (table 2). At the Middle Raccoon River at Panora gaging station, the July 9,1993 , flood-peak discharge of $22,400 \mathrm{ft}^{3} / \mathrm{s}$ is 1.1 times larger than the 100 -year recurrence-interval discharge (table 2). At the South Raccoon River at Redfield gaging station, the July 10 , 1993 , flood-peak discharge of $44,000 \mathrm{ft}^{3} / \mathrm{s}$ is 1.2 times larger than the 100-year recurrence-interval discharge (table 2) and the peak stage of $26.98 \mathrm{ft}$ exceeded the flood stage at this site by about $13.0 \mathrm{ft}$. At the Raccoon River at Van Meter gaging station, the July 10, 1993, flood-peak discharge of $70,100 \mathrm{ft}^{3} / \mathrm{s}$ is 1.3 times larger than the 100-year recurrence-interval discharge (table 2, fig. 4) and the peak stage of $26.34 \mathrm{ft}$ exceeded the flood stage at this site by about $13.3 \mathrm{ft}$.

\section{PROFILES FOR THE FLOOD OF JULY 9- 11,1993 , IN THE RACCOON RIVER BASIN, WEST-CENTRAL IOWA}

Water-surface-elevation profiles for the flood of July 9-11, 1993, in the Raccoon River Basin are shown in Appendix B (figs. 5-16). Profiles for the floods of June 1947 (figs. 6-7), March 1979 (figs. 6-11 and 14-15), and June 29-July 1, 1986 (figs. 6-7, 10-11, and 14-15) also are shown in Appendix B for comparative purposes. The flood profiles were determined from high-water marks generally located immediately downstream and 1 bridge-length upstream from selected bridges. The high-water marks were identified within a few days of passage of the flood peak and were later referenced to sea level by differential leveling. Low-water profiles measured on August 8-9, 1979 (figs. 6-8, 10-11, and 14-15), and November 20-21, 1996 (figs. 6-8 and 10-16), in the Raccoon River Basin also are shown in Appendix B to indicate the approximate low-end of the range of stages that can occur within the profiled reaches.

The profiles were defined using data collected by the USGS; with the following two exceptions: (1) the profiles of the flood of July 9-11, 1993, along the Raccoon, North Raccoon, and South Raccoon Rivers (figs. 5-11), were supplemented by water-surface elevations collected by the U.S. Army Corps of Engineers (William Riebe, Chief, Survey Branch, Rock Island District, written commun., February 1997); and (2) the profile of the flood of June 1947 along the Raccoon River (figs. 6-7) was supplemented by water-surface elevations collected by the City of Des Moines Engineer (Myers, 1963). The profiles between the measured 
water-surface elevations are represented by straight lines and are therefore only approximations of the actual water-surface elevations between the measurements. Water-surface elevations for ungaged bridge sites used in the 1993 flood profiles were collected at selected primary highway and paved county road bridges (figs. 1 and 5-16). Approximately 77 percent of the bridge sites used in the 1993 profiles were located less than 10 miles apart, about 21 percent were located between 10 and 20 miles apart, and about 2 percent were located between 20 and 30 miles apart. Flood elevations were not collected at both the upstream and downstream sides of all bridges. Water-surface elevations for the 1979 and 1986 floods were collected at the majority of bridges along the profiled reaches. Bridges along the North Raccoon, South Raccoon, and Middle Raccoon Rivers for which flood elevations were collected in 1979 or 1986 but were not collected in 1993 are noted on the profiles in figures 8,11 , and 15 .

All river miles used in the profiles (figs. 5-16) were measured from the most current 1:24,000-scale USGS topographic maps. River miles measured for the Raccoon, North Raccoon, South Raccoon, and Middle Raccoon Rivers were referenced to the mouth of the Raccoon River, and river miles measured for Brushy and Storm Creeks were referenced to the mouth of each respective creek. River miles were measured using a geographic information system. Measurements of river miles using larger- or smaller-scale cartographic data or different measurement methods may yield different values than those contained in this report. Bridges are designated by an index number derived from their respective locations using Public Land Survey System coordinates (township, range, section). For example, 7824-10 NW refers to a location in Township 78 North, Range 24 West, northwest quarter of section 10.

A bench mark and a reference point were established at the majority of the bridges in the profiled reaches to reference all the points along the profiles to a common datum. Bench-mark and reference-point descriptions and elevations for bridge sites used in the July 9-11, 1993, flood profiles are listed in Appendix C.

Bridge-deck and low-bridge-chord elevations are shown in figures 6-16 to indicate the relation of the bridge to the high- and low-water surfaces. For sloping bridges, the bridge-deck and low-bridge-chord elevations represent the lower end of each bridge.

\section{CONSIDERATIONS}

The user of this report is cautioned that the stagedischarge data presented herein are representative of the physical conditions of the basin at the time of the floods described. Changes in the basin can alter the flood magnitude for a specific frequency. Examples of these basin changes include, but are not limited to, extensive urbanization, implementation of agricultural conservation practices, and installation of drainage systems. Changes in the channel conditions immediately downstream from a streamflow-gaging station can substantially affect the stage-discharge relation. Examples of such changes include the construction of dams, bridges, or levees; changes in the flood-plain vegetative cover; straightening of the channel; and natural scour and fill. Temporary changes can be caused by ice and debris jams that produce backwater conditions that cause water-surface elevations to be higher than would occur in an unobstructed channel.

\section{SUMMARY}

This report provides information on the flood of July 9-11, 1993, in the Raccoon River Basin in westcentral Iowa. Information on the floods of June 1947, March 1979, and June 29-July 1, 1986, in the Raccoon River Basin is included for comparative purposes. The report provides information on flood stages and discharges and floodflow frequencies for streamflowgaging stations in the Raccoon River Basin using flood information collected through 1996. A flood history summarizes rainfall conditions and damages for floods that occurred during $1947,1958,1979,1986,1990$, and 1993. The July 9-11, 1993, flood is the largest known peak discharge at gaging stations Brushy Creek near Templeton (station number 05483318) $19,000 \mathrm{ft}^{3} / \mathrm{s}$, Middle Raccoon River near Bayard (station number 05483450) $27,500 \mathrm{ft}^{3} / \mathrm{s}$, Middle Raccoon River at Panora (station number 05483600 ) $22,400 \mathrm{ft}^{3} / \mathrm{s}$, South Raccoon River at Redfield (station number 05484000) $44,000 \mathrm{ft}^{3} / \mathrm{s}$, and Raccoon River at Van Meter (station number 05484500$) 70,100 \mathrm{ft}^{3} / \mathrm{s}$. The peak discharges were, respectively, $1.5,1.3,1.1,1.2$, and 1.3 times larger than calculated 100-year recurrence-interval discharges. Information on temporary bench marks and reference points established in the Raccoon River Basin during 1976-79 and 1995-97 also is included in the report. 


\section{REFERENCES}

Baebenroth, R.W., and Schaap, B.D., 1992, Floods of 1986 and 1990 in the Raccoon River Basin, west-central Iowa: U.S. Geological Survey Open-File Report 92-94, $144 \mathrm{p}$.

Carpenter, P.J., and Appel, D.H., 1966, Water-surface profiles of Raccoon River at Des Moines, Iowa: U.S. Geological Survey Open-file Report, 12 p.

Des Moines Register, 1990, June 17, 18, 20, and 22, newspaper articles.

1993, July 10,11,12,14, and 18, newspaper articles.

Eash, D.A., 1993, Estimating design-flood discharges for streams in Iowa using drainage-basin and channelgeometry characteristics: U.S. Geological Survey Water-Resources Investigation Report 93-4062, 96 p.

in press, Effects of the 1993 flood on the determination of flood magnitude and frequency in Iowa: U.S. Geological Survey Circular 1120-K.

Heinitz, A.J., 1980, Floods in the Raccoon River Basin: U.S. Geological Survey Open-File Report 80-162, 110 p.

Interagency Advisory Committee on Water Data, 1982, Guidelines for determining flood flow frequency: Hydrology Subcommittee Bulletin 17B, U.S. Geological Survey, Office of Water Data Coordination, $28 \mathrm{p}$. and appendices.

Iowa Department of Agriculture and Land Stewardship, 1993, Iowa climate review: Des Moines, Iowa, State Climatology Office, monthly summaries, v. 6, no. 7 , $25 \mathrm{p}$.

Iowa Natural Resources Council, 1953, An inventory of water resources and water problems, Des Moines River Basin: Des Moines, Iowa, Iowa Natural Resources Council Bulletin no. 1, 64 p.

Lara, O.G., 1978, Effects of urban development on the floodflow characteristics of the Walnut Creek Basin, Des Moines metropolitan area, Iowa: U.S. Geological Survey Water-Resources Investigations 78-11, 31 p.

1987, Method for estimating the magnitude and frequency of floods at ungaged sites on unregulated rural streams in Iowa: U.S. Geological Survey WaterResources Investigation Report 87-4132, 34 p.

Larimer, O.J., 1957, Drainage areas of Iowa streams: Iowa Highway Research Board Bulletin No. 7 (reprinted 1974), $439 \mathrm{p}$.

May, J.E., Gorman, J.G., Goodrich, R.D., Bobier, M.W., and Miller, V.E., 1997, Water resources data, Iowa, water year 1996: U.S. Geological Survey Water-Data Report IA-96-1, $578 \mathrm{p}$.
Monk, W.C., 1995, July 1993 flood damage to US-71 bridge over Brushy Creek, Carroll County, Iowa--Case Study, in 1993 Midwest Floods and Water Quality Best Management Practices: Washington, Transportation Research Board, National Research Council, Transportation Research Record, no. 1483, Highway and Facility Design, p. 38-46.

Myers, R.E., 1963, Floods at Des Moines, Iowa: U.S. Geological Survey Hydrologic Investigations Atlas HA-53, 1 sheet, scale 1:24,000.

Novak, C.E., 1985, WRD data reports preparation guide: Reston, Virginia, U.S. Geological Survey, 199 p.

Oschwald, W.R., Riecken, F.F., Dideriksen, R.I., Scholtes, W.H., and Schaller, F.W., 1965, Principal soils of Iowa: Ames, Iowa, Iowa State University, Department of Agronomy, Special Report no. 42, 77 p.

Owenby, J.R., and Ezell, D.S., 1992, Monthly station normals of temperature, precipitation, and heating and cooling degree days 1961-1990, Iowa: Asheville, N.C., National Climatic Data Center, National Oceanic and Atmospheric Administration, Climatography of the United States no. 81, $32 \mathrm{p}$.

Parrett, Charles, Melcher, N.B., and James, R.W., 1993, Flood discharges in the upper Mississippi River Basin, 1993: U.S. Geological Survey Circular 1120-A, 14 p.

Prior, J.C., 1991, Landforms of Iowa: Iowa City, Iowa, Iowa Department of Natural Resources, University of Iowa Press, $153 \mathrm{p}$.

Rantz, S.E., and others, 1982, Measurement and computation of streamflow--Volume 2. Computation of discharge: U.S. Geological Survey Water-Supply Paper 2175, p. 285-631.

Schaap, B.D., 1996, Delineation of flooding within the upper Mississippi River Basin--flood of June 18 through August 4, 1993, in Des Moines and vicinity, Iowa: U.S. Geological Survey Hydrologic Investigations Atlas HA 735-D, 2 sheets, scale 1:24,000.

Scientific Assessment and Strategy Team, 1994, Science for floodplain management into the 21st century: Washington, Preliminary Report of the Scientific Assessment and Strategy Team, Report of the Interagency Floodplain Management Review Committee to the Administration Floodplain Management Task Force, June 1994, $272 \mathrm{p}$.

Southard, Rodney, 1995, Flood volumes in the upper Mississippi River Basin, April 1 through September 30, 1993 : U.S. Geological Survey Circular 1120-H, 32 p.

Southard, R.E., Sneck-Fahrer, D.A., Anderson, C.J., Goodrich, R.D., and Gorman, J.G., 1994, Water resources data, Iowa, water year 1993: U.S. Geological Survey Water-Data Report IA-93-1, 388 p. 
U.S. Department of Commerce and National Oceanic and Atmospheric Administration, 1993, Hourly precipitation data, Iowa: Asheville, N.C., monthly summaries, v. 43, no. 7,24 p.

1994, The great flood of 1993: Rockville, Maryland, Natural Disaster Survey Report, 281 p.

U.S. Department of Commerce, National Oceanic and Atmospheric Administration, and Iowa Department of Agriculture and Land Stewardship, 1986a, Climatological data, Iowa: Asheville, N.C., monthly summaries, v. 97, no. 5,28 p.

1986b, Climatological data, Iowa: Asheville, N.C., monthly summaries, v. 97 , no. 6,30 p.

1990, Climatological data, Iowa: Asheville, N.C., monthly summaries, v. 101 , no. 6,36 p.

1993, Climatological data, Iowa: Asheville, N.C., monthly summaries, v. 104 , no. 7,40 p.

U.S. Department of Commerce, National Oceanic and Atmospheric Administration, and Iowa Department of Agriculture, 1979, Climatological data, Iowa: Asheville, N.C., monthly summaries, v. 90, no. 3, 21 p.
U.S. Department of Commerce, National Oceanic and Atmospheric Administration, and National Weather Service, 1986, Storm summary report, Iowa, May 1986: National Weather Service, WS Form F-2, 6 p. 1990, Storm summary report, Iowa, June 1990: National Weather Service, WS Form F-2, 23 p.

U.S. Department of Commerce, Weather Bureau, and Iowa Department of Agriculture, 1947a, Climatological data, Iowa: Des Moines, Iowa, monthly summaries, v. 58, no. 6, p. 66-72.

1947b, Climatological data, Iowa: Des Moines, Iowa, monthly summaries, v. 58 , no. 7 , p. 73-87.

U.S. Geological Survey, 1916-97, Water resources data, Iowa, water years 1915-96 (published annually): U.S. Geological Survey Water-Data Reports.

Wahl, K.L., Vining, K.C., and Wiche, G.J., 1993, Precipitation in the upper Mississippi River Basin, January 1 through July 31, 1993: U.S. Geological Survey Circular $1120-\mathrm{B}, 13 \mathrm{p}$.

Waite, Paul, 1988, Iowa precipitation frequencies: Des Moines, Iowa, Iowa Department of Agriculture and Land Stewardship, State Climatology Office, Climatology of Iowa Series no. 2, revised, 42 p. 


\section{APPENDIX A}

\section{PEAK STAGES AND DISCHARGES FOR STREAMFLOW-GAGING STATIONS IN THE RACCOON RIVER BASIN, WEST-CENTRAL IOWA}

The peak-stage and discharge data for streamflowgaging stations located in the Raccoon River Basin were compiled through September 30, 1996. The data are listed in chronological order. In general, independent peak discharges above a pre-selected base (partial-duration series) are listed for the continuous-record gaging stations. The magnitude of the selected base discharge, given in the "Remarks" section of the headnote, was determined so that it would be equaled or exceeded on the average about three times per year. Two peak discharges are considered independent if a plot of the recorded stages indicates a well-defined trough between the peaks and if the instantaneous discharge of the trough is 25 percent or more below that of the lower peak (Novak, 1985 , p. 93). Only annual peak discharges are listed for the crest-stage gaging stations.
The peak flow lists for each gaging-station are arranged in downstream order as explained in the annual water-data reports of the USGS (see "References"). The gaging stations are identified by a permanent number that also is used in figure 1 and in tables 1 and 2 of this report. The datum of the gage, when given, is above sea level. Flood stage as determined by the National Weather Service, when given, is the stage at which overflow of the natural banks of the stream begins to cause damage in the reach in which the elevation is measured.

Footnotes used throughout this appendix are selected so that each letter has the same meaning. For example, each occurrence of footnote "a" in any of the lists means "Affected by ice." Not all footnotes may appear in every list. 
(BLANK PAgE)

$-24-$ 


\section{North Raccoon River near Newell, Iowa}

(Discontinued September 30, 1995)

Location.--Lat $42^{\circ} 36^{\prime} 16^{\prime \prime}$, long $95^{\circ} 02^{\prime} 42^{\prime \prime}$ in NE1/4 NW1/4 sec. 24, T.90 N., R.36 W., Buena Vista County, Hydrologic Unit 07100006, on left bank $40 \mathrm{ft}$ downstream from bridge on State Highway 7, 0.8 mi upstream from Outlet Creek, 2.2 mi west of Newell, and at mile 198.1 upstream from mouth of Raccoon River.

Drainage area.--233 $\mathrm{mi}^{2}$.

Gage.--Water-stage recorder. Datum is $1,235.50 \mathrm{ft}$ above sea level.

Stage-discharge relation.--Defined by current-meter measurements.

Remarks.--Base for partial-duration series, $750 \mathrm{ft}^{3} / \mathrm{s}$.

Peak stages and discharges

[Water year, October 1-September 30; ft, feet above gage datum; $\mathrm{ft}^{3} / \mathrm{s}$, cubic feet per second; --, not determined]

\begin{tabular}{|c|c|c|c|}
\hline Water year & Date & $\begin{array}{l}\text { Gage height } \\
\text { (ft) }\end{array}$ & $\begin{array}{c}\text { Discharge } \\
\left(\mathrm{ft}^{3} / \mathrm{s}\right)\end{array}$ \\
\hline \multirow[t]{11}{*}{1983} & Oct. 2,1982 & $\cdots$ & 1,200 \\
\hline & Oct. $\quad 9,1982$ & -- & 1,300 \\
\hline & Feb. 22,1983 & 14.51 & 811 \\
\hline & Mar. 7,1983 & 15.40 & 1,740 \\
\hline & Mar. 17,1983 & 13.52 & 947 \\
\hline & Apr. 2,1983 & 14.76 & 1,400 \\
\hline & Apr. 13,1983 & 14.72 & 1,380 \\
\hline & May 3,1983 & 13.95 & 1,080 \\
\hline & June 14,1983 & 13.59 & 967 \\
\hline & June 21,1983 & 16.30 & 2,450 \\
\hline & June 30,1983 & 16.17 & 2,320 \\
\hline \multirow[t]{9}{*}{1984} & Feb. 17,1984 & $a_{-}$ & $b_{1,020}$ \\
\hline & Apr. $\quad 9,1984$ & 14.20 & 1,170 \\
\hline & Apr. 13,1984 & 14.49 & 1,290 \\
\hline & Apr. 23,1984 & 13.91 & 1,070 \\
\hline & May 28,1984 & 13.36 & 906 \\
\hline & June 2,1984 & 14.83 & 1,440 \\
\hline & June $\quad 6,1984$ & -- & 1,800 \\
\hline & June 12,1984 & -- & 2,400 \\
\hline & June 17,1984 & 16.73 & 2,850 \\
\hline \multirow[t]{2}{*}{1985} & Dec. 29,1984 & ${ }^{\mathrm{a}} 12.94$ & - \\
\hline & May 15,1985 & 12.87 & 776 \\
\hline \multirow[t]{5}{*}{1986} & Mar. 20,1986 & 14.76 & 1,410 \\
\hline & Apr. $\quad 5,1986$ & 13.86 & 1,060 \\
\hline & Apr. 28,1986 & 15.45 & 1,780 \\
\hline & May 13,1986 & 15.61 & 1,880 \\
\hline & June 5,1986 & 13.00 & 805 \\
\hline
\end{tabular}


05482135 North Raccoon River near Newell, Iowa

Peak stages and discharges--Continued

\begin{tabular}{|c|c|c|c|}
\hline Water year & Date & $\begin{array}{l}\text { Gage height } \\
\text { (ft) }\end{array}$ & $\begin{array}{c}\text { Discharge } \\
\left(\mathrm{ft}^{3} / \mathrm{s}\right)\end{array}$ \\
\hline \multirow[t]{4}{*}{1987} & Oct. 12,1986 & 14.22 & 1,190 \\
\hline & July 12,1987 & 14.13 & 1,160 \\
\hline & July 22,1987 & 13.49 & 974 \\
\hline & Sept. 17,1987 & 14.81 & 1,440 \\
\hline 1988 & Aug. 22, 1988 & 12.20 & 649 \\
\hline \multirow[t]{2}{*}{1989} & Mar. 10,1989 & ${ }^{a} 13.90$ & -- \\
\hline & May 24,1989 & 11.50 & 504 \\
\hline \multirow[t]{3}{*}{1990} & June 2,1990 & 13.31 & 917 \\
\hline & June 13,1990 & 14.22 & 1.130 \\
\hline & June 17,1990 & 16.33 & 2,380 \\
\hline \multirow[t]{8}{*}{1991} & Apr. 15,1991 & 14.63 & 1,360 \\
\hline & Apr. 27,1991 & 13.96 & 1,030 \\
\hline & May 6,1991 & 14.48 & 1,290 \\
\hline & May 19,1991 & 15.06 & 1,590 \\
\hline & June 1,1991 & 14.37 & 1,240 \\
\hline & June 4,1991 & 15.57 & 1,910 \\
\hline & June 15,1991 & 15.24 & 1,700 \\
\hline & Aug. 8,1991 & 14.18 & 1,180 \\
\hline \multirow[t]{5}{*}{1992} & Dec. 13,1991 & 12.80 & 793 \\
\hline & Mar. 9,1992 & 13.92 & 1,100 \\
\hline & Apr. 22,1992 & 14.77 & 1,430 \\
\hline & June 17,1992 & 13.21 & 899 \\
\hline & July 12,1992 & 14.46 & 1,280 \\
\hline \multirow[t]{12}{*}{1993} & Oct. 10,1992 & 14.43 & 1,260 \\
\hline & Mar. 29, 1993 & 16.16 & 2,380 \\
\hline & Apr. 20,1993 & 15.49 & 1,860 \\
\hline & May 11,1993 & 13.58 & 1,000 \\
\hline & May 31,1993 & 13.24 & 907 \\
\hline & June 14,1993 & 15.40 & 1,800 \\
\hline & June 25,1993 & 14.13 & 1,160 \\
\hline & July 1,1993 & 15.66 & 1,970 \\
\hline & July 11,1993 & 16.20 & 2,420 \\
\hline & July 15,1993 & 15.98 & 2,230 \\
\hline & Aug. 17, 1993 & 14.91 & 1,500 \\
\hline & Aug. 30,1993 & 13.10 & 870 \\
\hline 1994 & -- & -- & -- \\
\hline \multirow[t]{4}{*}{1995} & Apr. 21,1995 & 12.87 & 826 \\
\hline & May 10,1995 & 13.35 & 969 \\
\hline & May 14,1995 & 14.35 & 1,280 \\
\hline & May 29,1995 & 14.19 & 1,200 \\
\hline
\end{tabular}

${ }^{\mathrm{a} A f f e c t e d}$ by ice.

bApproximate. 


\section{Big Cedar Creek near Varina, Iowa}

(Discontinued September 30, 1991)

Location.--Lat $42^{\circ} 41^{\prime} 16^{\prime \prime}$, long 94²7'52", in NE1/4 NE1/4 sec. 24, T.91 N., R.34 W., Pocahontas County, Hydrologic Unit 07100006, on left bank $2 \mathrm{ft}$ downstream from bridge on County Road N33, $2.0 \mathrm{mi}$ downstream from Drainage Ditch 21, 3.5 mi upstream from Drainage Ditch 74, and 5.5 mi northeast of Varina.

Drainage area.--80.0 $\mathrm{mi}^{2}$.

Gage.--Water-stage recorder. Datum is $1,225.12 \mathrm{ft}$ above sea level.

Stage-discharge relation.--Defined by current-meter measurements.

Remarks.--Base for partial duration series, $400 \mathrm{ft}^{3} / \mathrm{s}$.

\section{Peak stages and discharges}

[Water year, October 1-September 30; $\mathrm{ft}$, feet above gage datum; $\mathrm{ft}^{3} / \mathrm{s}$, cubic feet per second; --, not determined]

\begin{tabular}{|c|c|c|c|}
\hline Water year & Date & $\begin{array}{c}\text { Gage height } \\
\text { (ft) }\end{array}$ & $\begin{array}{l}\text { Discharge } \\
\left(\mathrm{ft}^{3} / \mathrm{s}\right)\end{array}$ \\
\hline \multirow[t]{3}{*}{1960} & Mar. 27,1960 & ${ }^{\mathrm{a}} 13.13$ & - \\
\hline & Mar. 27, 1960 & 11.42 & 1,020 \\
\hline & June 16,1960 & 8.27 & 466 \\
\hline \multirow[t]{3}{*}{1961} & Mar. 2, 1961 & -- & 400 \\
\hline & Mar. 25,1961 & $\mathrm{c}_{11.88}$ & 1,460 \\
\hline & Mar. 29,1962 & ${ }^{\mathrm{a}} 14.49$ & - \\
\hline \multirow[t]{5}{*}{1962} & Mar. 31,1962 & 13.68 & $\mathrm{~b}_{1,000}$ \\
\hline & July 2,1962 & 8.91 & 665 \\
\hline & July 4,1962 & 10.15 & 960 \\
\hline & July 28,1962 & 7.89 & 452 \\
\hline & Aug. 31, 1962 & 13.68 & 2,080 \\
\hline \multirow[t]{2}{*}{1963} & Mar. 15,1963 & 7.51 & - \\
\hline & June 2,1963 & 6.57 & 333 \\
\hline 1964 & May 6,1964 & 6.23 & 291 \\
\hline \multirow[t]{3}{*}{1965} & Apr. $\quad 6,1965$ & ${ }^{\mathrm{a}} 15.05$ & -. \\
\hline & Apr. 8,1965 & 10.17 & 1,060 \\
\hline & June 6,1965 & 7.00 & 404 \\
\hline \multirow[t]{2}{*}{1966} & Oct. $\quad 1,1965$ & ${ }^{d} 6.31$ & 257 \\
\hline & Mar. 31, 1966 & 5.84 & 237 \\
\hline \multirow[t]{2}{*}{1967} & June 10,1967 & 7.82 & 548 \\
\hline & June 15,1967 & 9.28 & 852 \\
\hline 1968 & July 19,1968 & 3.99 & 45 \\
\hline \multirow[t]{6}{*}{1969} & Mar. 24,1969 & ${ }^{a} 10.44$ & $b_{700}$ \\
\hline & Apr. $\quad 4,1969$ & 8.89 & 744 \\
\hline & June 23,1969 & 8.04 & 506 \\
\hline & June 25,1969 & 10.76 & 992 \\
\hline & June 29,1969 & 7.37 & 412 \\
\hline & July 27,1969 & 10.49 & 938 \\
\hline 1970 & May 13,1970 & 8.02 & 554 \\
\hline
\end{tabular}




\section{Big Cedar Creek near Varina, Iowa}

\section{Peak stages and discharges--Continued}

\begin{tabular}{|c|c|c|c|}
\hline Water year & Date & $\begin{array}{l}\text { Gage height } \\
\text { (ft) }\end{array}$ & $\begin{array}{c}\text { Discharge } \\
\left(\mathrm{ft}^{3} / \mathrm{s}\right)\end{array}$ \\
\hline \multirow[t]{4}{*}{1971} & Feb. 19,1971 & ${ }^{\mathrm{a}} 11.18$ & ${ }^{b} 800$ \\
\hline & Mar. 13, 1971 & $a_{-}$ & b880 \\
\hline & Mar. 28, 1971 & 8.25 & 595 \\
\hline & June 7,1971 & 10.66 & 1,010 \\
\hline 1972 & Aug. $\quad 6,1972$ & 7.37 & 400 \\
\hline \multirow[t]{6}{*}{1973} & Mar. 11,1973 & 7.43 & 485 \\
\hline & Mar. 14,1973 & 7.25 & 459 \\
\hline & Apr. 16, 1973 & 6.84 & 404 \\
\hline & May 28,1973 & 7.78 & 530 \\
\hline & Aug. 23,1973 & 9.82 & 904 \\
\hline & Sept. 26,1973 & 9.25 & 850 \\
\hline \multirow[t]{2}{*}{1974} & Oct. 11,1973 & 7.75 & 573 \\
\hline & Nov. 21,1973 & 8.11 & 642 \\
\hline \multirow[t]{5}{*}{1975} & Apr. $\quad 9,1975$ & -- & b800 \\
\hline & Apr. 12,1975 & -- & ${ }^{b} 600$ \\
\hline & Apr. 28,1975 & 10.88 & 1,250 \\
\hline & May 11,1975 & 6.78 & 413 \\
\hline & June 18,1975 & 7.04 & 452 \\
\hline 1976 & June 29,1976 & 4.71 & 157 \\
\hline 1977 & Mar. $\quad 9,1977$ & $a_{3.91}$ & ${ }^{b} 64$ \\
\hline \multirow[t]{2}{*}{1978} & July $\quad 6,1978$ & 10.39 & 818 \\
\hline & Sept. 14,1978 & 10.02 & 788 \\
\hline \multirow[t]{5}{*}{1979} & Mar. 24, 1979 & ${ }^{\mathrm{a}} 16.29$ & $\mathrm{~b}_{2,050}$ \\
\hline & June 27,1979 & 8.06 & 509 \\
\hline & July 30,1979 & 8.49 & 573 \\
\hline & Aug. 20, 1979 & 7.46 & 424 \\
\hline & Aug. 21, 1979 & 12.29 & 1,220 \\
\hline \multirow[t]{2}{*}{1980} & Mar. 15,1980 & a 8.44 & -- \\
\hline & Apr. 3,1980 & 6.59 & 385 \\
\hline 1981 & June 13,1981 & 6.87 & 372 \\
\hline \multirow[t]{2}{*}{1982} & July $\quad 6,1982$ & 7.48 & 459 \\
\hline & July 10,1982 & 7.71 & 488 \\
\hline \multirow[t]{12}{*}{1983} & Oct. $\quad 1,1982$ & 8.15 & 551 \\
\hline & Oct. $\quad 9,1982$ & 7.97 & 533 \\
\hline & Dec. 25,1982 & 7.02 & 449 \\
\hline & Dec. 29,1982 & 7.14 & 468 \\
\hline & Feb. 23,1983 & 7.54 & 535 \\
\hline & Feb. 27,1983 & 7.05 & 454 \\
\hline & Mar. 6,1983 & 9.53 & 937 \\
\hline & Mar. 16, 1983 & 6.72 & 404 \\
\hline & Apr. $\quad 1,1983$ & 7.91 & 603 \\
\hline & Apr. 13,1983 & 8.29 & 678 \\
\hline & Apr. 16,1983 & 7.47 & 523 \\
\hline & May 3,1983 & 6.91 & 432 \\
\hline
\end{tabular}




\section{Big Cedar Creek near Varina, Iowa}

Peak stages and discharges--Continued

\begin{tabular}{|c|c|c|c|}
\hline Water year & Date & $\begin{array}{l}\text { Gage height } \\
\text { (ft) }\end{array}$ & $\begin{array}{c}\text { Discharge } \\
\left(\mathrm{ft}^{3} / \mathrm{s}\right)\end{array}$ \\
\hline \multirow[t]{2}{*}{ 1983--Continued } & June 20,1983 & 11.03 & 1,180 \\
\hline & June 30,1983 & 9.52 & 868 \\
\hline \multirow[t]{9}{*}{1984} & Feb. 16,1984 & a-- & $b_{750}$ \\
\hline & Feb. 23,1984 & a_- & b860 \\
\hline & Apr. $\quad 9,1984$ & 7.27 & 457 \\
\hline & Apr. 23,1984 & 7.37 & 472 \\
\hline & May 1,1984 & 9.29 & 834 \\
\hline & June 7,1984 & 9.32 & 841 \\
\hline & June 13,1984 & 9.62 & 910 \\
\hline & June 16,1984 & 12.77 & 1,710 \\
\hline & June 23,1984 & 8.15 & 610 \\
\hline \multirow[t]{2}{*}{1985} & Dec. 28,1984 & a 7.24 & -- \\
\hline & May 24, 1985 & 5.90 & 302 \\
\hline \multirow[t]{7}{*}{1986} & Mar. 3, 1986 & -- & $\mathrm{b}_{550}$ \\
\hline & Mar. 18, 1986 & 10.05 & 1,010 \\
\hline & Apr. 5,1986 & 8.21 & 659 \\
\hline & Apr. 28,1986 & 7.58 & 533 \\
\hline & May 11,1986 & 7.07 & 456 \\
\hline & May 13,1986 & 11.80 & 1,430 \\
\hline & Aug. 13, 1986 & 7.13 & 467 \\
\hline \multirow[t]{2}{*}{1987} & Oct. 12,1986 & 8.09 & 632 \\
\hline & May 26,1987 & 7.40 & 528 \\
\hline \multirow[t]{2}{*}{1988} & Mar. $\quad 1,1988$ & $a_{5} .78$ & -- \\
\hline & Aug. 22, 1988 & 5.74 & 316 \\
\hline \multirow[t]{2}{*}{1989} & Mar. 10, 1989 & '6.83 & -- \\
\hline & May 24, 1989 & 4.40 & 168 \\
\hline \multirow[t]{4}{*}{1990} & June 3,1990 & 7.07 & 482 \\
\hline & June 17,1990 & 11.50 & 1,410 \\
\hline & June 19,1990 & 12.09 & 1,580 \\
\hline & Aug. 25, 1990 & 7.47 & 538 \\
\hline \multirow[t]{11}{*}{1991} & Mar. 23, 1991 & 9.19 & 860 \\
\hline & Apr. 14,1991 & 9.65 & 960 \\
\hline & Apr. 19,1991 & 6.47 & 405 \\
\hline & Apr. 27,1991 & 7.71 & 572 \\
\hline & Apr. 30,1991 & 7.49 & 541 \\
\hline & May 5,1991 & 9.21 & 864 \\
\hline & May 18,1991 & 8.07 & 628 \\
\hline & May 31,1991 & 7.72 & 574 \\
\hline & June 4,1991 & 11.32 & 1,360 \\
\hline & June 15,1991 & 8.20 & 654 \\
\hline & Aug. 8,1991 & 6.82 & 449 \\
\hline
\end{tabular}

${ }^{a}$ Affected by ice.

${ }^{b}$ Approximate.

${ }^{\mathrm{c}}$ Gage height determined from floodmark.

${ }^{\mathrm{d}}$ Stage decreasing. 


\section{North Raccoon River near Sac City, Iowa}

Location.--Lat 42²1'16", long 9459'26", in NW1/4 NW1/4 sec. 13, T.87 N., R.36 W., Sac County, Hydrologic Unit 07100006 , on right bank $5 \mathrm{ft}$ downstream from bridge on county road, $2.1 \mathrm{mi}$ upstream from Indian Creek, 0.3 mi upstream from Drainage Ditch 73, 4.6 mi south of Sac City, and at mile 167.1 upstream from mouth of Raccoon River.

Drainage area.--700 $\mathrm{mi}^{2}$.

Gage.--Water-stage recorder. Datum is $1,146.03 \mathrm{ft}$ above sea level. Prior to Oct. 1, 1987, at site 1.7 mi downstream, at datum $1.43 \mathrm{ft}$ lower.

Stage-discharge relation.--Defined by current-meter measurements.

Bankfull stage.--13 ft (determined by National Weather Service).

Remarks.--Base for partial-duration series, $2,000 \mathrm{ft}^{3} / \mathrm{s}$.

\section{Peak stages and discharges}

[Water year, October $1-S e p t e m b e r 30 ; \mathrm{ft}$, feet above gage datum; $\mathrm{ft}^{3} / \mathrm{s}$, cubic feet per second; --, not determined]

\begin{tabular}{|c|c|c|c|}
\hline Water year & Date & $\begin{array}{c}\text { Gage height } \\
\text { (ft) }\end{array}$ & $\begin{array}{c}\text { Discharge } \\
\left(\mathrm{ft}^{3} / \mathrm{s}\right)\end{array}$ \\
\hline 1954 & June 21,1954 & ${ }^{\mathrm{c}} 15.61$ & 7,000 \\
\hline \multicolumn{4}{|c|}{ (Systematic operation of gage began June 1, 1958.) } \\
\hline 1958 & June 4,1958 & 13.44 & $\mathrm{e}_{4,560}$ \\
\hline 1959 & May 31,1959 & 14.51 & 5,200 \\
\hline \multirow[t]{4}{*}{1960} & Mar. 30,1960 & 16.73 & 9,020 \\
\hline & May 22,1960 & 9.68 & 2,100 \\
\hline & May 26,1960 & 10.94 & 2,840 \\
\hline & June 19,1960 & 10.47 & 2,640 \\
\hline 1961 & Mar. 28, 1961 & 13.16 & 4,420 \\
\hline \multirow[t]{4}{*}{1962} & Mar. 29,1962 & 15.83 & 7,730 \\
\hline & June 9,1962 & 9.96 & 2,010 \\
\hline & July $\quad 5,1962$ & 10.32 & 2,160 \\
\hline & Sept. 1,1962 & 18.12 & 10,800 \\
\hline 1963 & June 3,1963 & 9.32 & 1,910 \\
\hline 1964 & May 7,1964 & 7.47 & 1,100 \\
\hline \multirow[t]{2}{*}{1965} & Apr. 6,1965 & 15.59 & 6,960 \\
\hline & Sept. 28,1965 & 9.82 & 2,020 \\
\hline 1966 & June 12,1966 & 9.49 & 1,860 \\
\hline \multirow[t]{2}{*}{1967} & June 9,1967 & 12.06 & 3,230 \\
\hline & June 16,1967 & 15.73 & 7,150 \\
\hline 1968 & June 25,1968 & 4.89 & 354 \\
\hline \multirow[t]{6}{*}{1969} & Oct. 18,1968 & 10.57 & 2,110 \\
\hline & Mar. 26, 1969 & 12.94 & 3,790 \\
\hline & Apr. $\quad 5,1969$ & 14.65 & 5,370 \\
\hline & June 7,1969 & 10.69 & 2,430 \\
\hline & June 27,1969 & 13.93 & 4,850 \\
\hline & July 28,1969 & 12.72 & 3,780 \\
\hline
\end{tabular}


$\mathbf{0 5 4 8 2 3 0 0}$ North Raccoon River near Sac City, Iowa

Peak stages and discharges--Continued

\begin{tabular}{|c|c|c|c|}
\hline Water year & Date & $\begin{array}{c}\text { Gage height } \\
\text { (ft) }\end{array}$ & $\begin{array}{c}\text { Discharge } \\
\left(\mathrm{ft}^{3} / \mathrm{s}\right)\end{array}$ \\
\hline 1970 & May 14,1970 & 12.75 & 3,630 \\
\hline \multirow[t]{4}{*}{1971} & Feb. 19,1971 & ${ }^{\mathrm{a}} 14.25$ & $\mathrm{~b}_{4,000}$ \\
\hline & Mar. 14,1971 & 13.40 & 4,200 \\
\hline & Mar. 29,1971 & 10.62 & 2,490 \\
\hline & June 10,1971 & 11.82 & 3,070 \\
\hline 1972 & July 17,1972 & 13.43 & 4,140 \\
\hline \multirow[t]{10}{*}{1973} & Nov. 3,1972 & 9.73 & 2,010 \\
\hline & Mar. 4,1973 & ${ }^{\mathrm{a}} 12.18$ & $b_{2,680}$ \\
\hline & Mar. 14,1973 & 11.54 & 2,890 \\
\hline & Mar. 26, 1973 & 10.46 & 2,360 \\
\hline & Apr. 16,1973 & 10.22 & 2,240 \\
\hline & May 28,1973 & -- & $\mathrm{b}_{2,790}$ \\
\hline & July $\quad 2,1973$ & 13.16 & 3,930 \\
\hline & July $\quad 9,1973$ & -- & $b_{3,190}$ \\
\hline & Aug. 24, 1973 & 12.62 & 3,550 \\
\hline & Sept. 27,1973 & 13.90 & 4,520 \\
\hline \multirow[t]{3}{*}{1974} & Oct. 12,1973 & 13.33 & 4,060 \\
\hline & Nov. 21,1973 & 12.11 & 3,250 \\
\hline & May 19,1974 & 11.21 & 2,400 \\
\hline \multirow[t]{3}{*}{1975} & Apr. 28,1975 & 14.35 & 4,570 \\
\hline & May 12,1975 & 10.37 & 2,160 \\
\hline & June 19,1975 & 11.12 & 2,590 \\
\hline 1976 & May 25,1976 & 5.73 & 557 \\
\hline \multirow[t]{2}{*}{1977} & Mar. 12, 1977 & a5.94 & -- \\
\hline & Aug. $\quad 9,1977$ & 5.43 & 479 \\
\hline \multirow[t]{3}{*}{1978} & June 18,1978 & 11.53 & 2,890 \\
\hline & July 7,1978 & 13.47 & 4,180 \\
\hline & Sept. 14,1978 & 15.23 & 5,880 \\
\hline \multirow[t]{4}{*}{1979} & Mar. 23, 1979 & 18.02 & 13,100 \\
\hline & Mar. 30, 1979 & 16.64 & 7,750 \\
\hline & June 28,1979 & 15.43 & 5,930 \\
\hline & Aug. 24, 1979 & 13.22 & 3,980 \\
\hline 1980 & Apr. $\quad 4,1980$ & 8.90 & 1,720 \\
\hline 1981 & June 14,1981 & 7.96 & 1,290 \\
\hline \multirow[t]{6}{*}{1982} & Mar. 20, 1982 & 10.92 & 2,610 \\
\hline & May 27,1982 & 11.52 & 2,980 \\
\hline & July 7,1982 & 13.64 & 4,410 \\
\hline & July 11,1982 & 12.50 & 3,560 \\
\hline & July 18,1982 & 13.25 & 4,100 \\
\hline & Sept. 14,1982 & 9.66 & 2,110 \\
\hline \multirow[t]{4}{*}{1983} & Oct. $\quad 3,1982$ & 12.25 & 3,360 \\
\hline & Oct. $\quad 9,1982$ & 12.95 & 3,840 \\
\hline & Feb. 23,1983 & $\mathrm{c}_{12.22}$ & 3,380 \\
\hline & Mar. 7,1983 & $f_{16.16}$ & 7,200 \\
\hline
\end{tabular}




\section{North Raccoon River near Sac City, Iowa}

Peak stages and discharges--Continued

\begin{tabular}{|c|c|c|c|}
\hline Water year & Date & $\begin{array}{l}\text { Gage height } \\
\text { (ft) }\end{array}$ & $\begin{array}{c}\text { Discharge } \\
\left(\mathrm{ft}^{3} / \mathrm{s}\right)\end{array}$ \\
\hline \multirow[t]{7}{*}{ 1983--Continued } & Mar. 16,1983 & $\mathrm{~g}_{11.98}$ & 3,250 \\
\hline & Apr. 2,1983 & 13.72 & 4,510 \\
\hline & Apr. 14,1983 & 13.54 & 4,370 \\
\hline & May 3,1983 & 12.50 & 3,590 \\
\hline & June 15,1983 & 10.27 & 2,400 \\
\hline & June 21,1983 & $\mathrm{~g}_{17.31}$ & 9,390 \\
\hline & June 30,1983 & 16.31 & 7,230 \\
\hline \multirow[t]{12}{*}{1984} & Feb. 17,1984 & 10.64 & 2,580 \\
\hline & Feb. 23,1984 & 9.82 & 2,210 \\
\hline & Apr. $\quad 4,1984$ & 10.25 & 2,410 \\
\hline & Apr. $\quad 9,1984$ & 12.27 & 3,460 \\
\hline & Apr. 14,1984 & 12.20 & 3,410 \\
\hline & Apr. 23,1984 & 11.87 & 3,210 \\
\hline & Apr. 27,1984 & 11.27 & 2,890 \\
\hline & May 1,1984 & 13.78 & 4,540 \\
\hline & May 28, 1984 & 11.94 & 3,250 \\
\hline & June 8,1984 & 16.47 & 7,790 \\
\hline & June 13,1984 & 14.62 & 5,270 \\
\hline & June 18,1984 & 15.70 & 6,460 \\
\hline 1985 & May 15,1985 & b,h 9.12 & ${ }^{b} 1,800$ \\
\hline \multirow[t]{7}{*}{1986} & Mar. 19, 1986 & 14.82 & 5,430 \\
\hline & Apr. $\quad 5,1986$ & 12.69 & 3,690 \\
\hline & Apr. 28,1986 & 13.55 & 4,160 \\
\hline & May 11,1986 & 12.52 & 3,580 \\
\hline & May 13,1986 & 14.12 & 4,790 \\
\hline & Sept. 21, 1986 & 12.19 & 3,290 \\
\hline & Sept. 25,1986 & 10.45 & 2,370 \\
\hline \multirow[t]{6}{*}{1987} & Oct. 12,1986 & 12.85 & 3,670 \\
\hline & Apr. 15,1987 & 10.61 & 2,460 \\
\hline & May 27,1987 & 11.64 & 2,930 \\
\hline & July 12,1987 & 14.01 & 4,570 \\
\hline & Sept. 17,1987 & 11.25 & 2,740 \\
\hline & (Gage moved to nev & n October 1,1 & \\
\hline \multirow[t]{2}{*}{1988} & Feb. 20,1988 & " 10.63 & -- \\
\hline & Aug. 23, 1988 & 10.12 & 1,040 \\
\hline 1989 & Mar. 11, 1989 & "a 12.67 & $b_{1,700}$ \\
\hline \multirow[t]{7}{*}{1990} & May 20,1990 & 14.05 & 2,890 \\
\hline & May 26, 1990 & 12.77 & 2,210 \\
\hline & June 3,1990 & 13.68 & 2,640 \\
\hline & June 14,1990 & 14.60 & 3,280 \\
\hline & June 17,1990 & 20.14 & 9,930 \\
\hline & June 28,1990 & 14.41 & 3,140 \\
\hline & Aug. 26,1990 & 15.77 & 4,430 \\
\hline
\end{tabular}




\section{North Raccoon River near Sac City, Iowa}

Peak stages and discharges--Continued

\begin{tabular}{|c|c|c|c|}
\hline Water year & Date & $\begin{array}{c}\text { Gage height } \\
\text { (ft) }\end{array}$ & $\begin{array}{c}\text { Discharge } \\
\left(\mathrm{ft}^{3} / \mathrm{s}\right)\end{array}$ \\
\hline \multirow[t]{11}{*}{1991} & Mar. 23, 1991 & 15.11 & 3,560 \\
\hline & Apr. 15,1991 & 16.07 & 4,330 \\
\hline & Apr. 19,1991 & 13.42 & 2,570 \\
\hline & Apr. 27,1991 & 14.96 & 3,480 \\
\hline & Apr. 30,1991 & 14.42 & 3,150 \\
\hline & May 6,1991 & 16.15 & 4,400 \\
\hline & May 18,1991 & 15.23 & 3,670 \\
\hline & June 1,1991 & 15.68 & 4,010 \\
\hline & June 5,1991 & 16.84 & 4,990 \\
\hline & June 15,1991 & 16.59 & 4,850 \\
\hline & Aug. 8,1991 & 12.90 & 2,190 \\
\hline \multirow[t]{5}{*}{1992} & Jan. 23,1992 & a-- & 2,770 \\
\hline & Mar. 10, 1992 & 13.20 & 2,390 \\
\hline & Apr. 22,1992 & 15.21 & 3,780 \\
\hline & June 18,1992 & 12.74 & 2,140 \\
\hline & July 14,1992 & 16.51 & 4,990 \\
\hline \multirow[t]{10}{*}{1993} & Mar. 30, 1993 & 17.47 & 6,450 \\
\hline & Apr. 20,1993 & 16.91 & 5,820 \\
\hline & May 11,1993 & 13.95 & 3,000 \\
\hline & June 17,1993 & 14.91 & 3,690 \\
\hline & June 25,1993 & 12.97 & 2,330 \\
\hline & June 30,1993 & 16.02 & 4,800 \\
\hline & July 11,1993 & 17.55 & 6,550 \\
\hline & July 18,1993 & 15.55 & 4,270 \\
\hline & July 25,1993 & 15.69 & 4,330 \\
\hline & Aug. 31, 1993 & 12.76 & 2,150 \\
\hline \multirow[t]{3}{*}{1994} & Mar. 5, 1994 & 16.13 & 4,890 \\
\hline & June 13,1994 & 13.83 & 2,820 \\
\hline & June 24,1994 & 13.74 & 2,750 \\
\hline \multirow[t]{4}{*}{1995} & Apr. 21,1995 & 12.53 & 2,200 \\
\hline & May 10,1995 & 13.31 & 2,770 \\
\hline & May 14,1995 & 13.79 & 3,150 \\
\hline & May 28,1995 & 15.11 & 4,310 \\
\hline \multirow[t]{5}{*}{1996} & May 29,1996 & 12.72 & 2,270 \\
\hline & June 17,1996 & 13.76 & 3,050 \\
\hline & June 21,1996 & 17.65 & 6,990 \\
\hline & Aug. 6,1996 & 14.66 & 3,800 \\
\hline & Aug. 12, 1996 & 12.73 & 2,260 \\
\hline
\end{tabular}

\footnotetext{
aAffected by ice.

${ }^{\mathrm{b}}$ Approximate.

${ }^{c}$ Gage height determined from floodmark.

${ }^{\mathrm{e}}$ Peak for 1958 is from June 1 to September 30.

${ }^{f}$ From graph absed on outside gage height.

${ }^{\mathrm{g}}$ From outside gage.

${ }^{\text {h}}$ Affected by backwater.
} 


\section{North Raccoon River near Jefferson, Iowa}

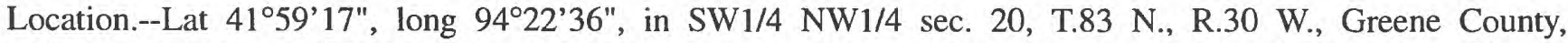
Hydrologic Unit 07100006, on right bank $3 \mathrm{ft}$ downstream from bridge on State Highway 4, $0.1 \mathrm{mi}$ downstream from drainage Ditches 33 and 40, 1.9 mi south of Jefferson, 4.7 mi upstream from Hardin Creek, and at mile 92.0 upstream from mouth of Raccoon River.

Drainage area.--1,619 $\mathrm{mi}^{2}$.

Gage.--Water-stage recorder. Datum is $967.09 \mathrm{ft}$ above sea level. Prior to Apr. 22, 1946, nonrecording gage at site 4 mi upstream at different datum. Apr. 22 to June 25, 1946, nonrecording gage; June 26, 1946, to Sept. 30, 1955, water-stage recorder; Oct. 1, 1955 to Apr. 30, 1958, nonrecording gage, at present site and datum.

Stage-discharge relation.--Defined by current-meter measurements.

Flood stage.--10 ft.

Remarks.--Base for partial-duration series, $4,000 \mathrm{ft}^{3} / \mathrm{s}$.

Peak stages and discharges

[Water year, October 1-September 30; $\mathrm{ft}$, feet above gage datum; $\mathrm{ft}^{3} / \mathrm{s}$, cubic feet per second; --, not determined]

\begin{tabular}{|c|c|c|c|}
\hline Water year & Date & $\begin{array}{l}\text { Gage height } \\
\text { (ft) }\end{array}$ & $\begin{array}{c}\text { Discharge } \\
\left(\mathrm{ft}^{3} / \mathrm{s}\right)\end{array}$ \\
\hline \multicolumn{4}{|c|}{ (Systematic operation of gage began in March 1940.) } \\
\hline 1940 & Aug. 28, 1940 & 10.9 & 4,030 \\
\hline 1941 & June 14,1941 & 9.1 & 2,420 \\
\hline 1942 & July 15,1942 & 10.5 & 3,590 \\
\hline 1943 & Aug. 13, 1943 & 15.5 & 9,480 \\
\hline \multirow[t]{2}{*}{1944} & May 22,1944 & 15.4 & 9,860 \\
\hline & June 14,1944 & 16.2 & 11,900 \\
\hline \multirow[t]{7}{*}{1945} & Mar. 12,1945 & 12.9 & 6,880 \\
\hline & Apr. 18,1945 & 10.6 & 4,130 \\
\hline & Apr. 25,1945 & 14.2 & 8,700 \\
\hline & May 24,1945 & 13.1 & 7,120 \\
\hline & June 3,1945 & 14.3 & 8,780 \\
\hline & June 10,1945 & 13.5 & 7,630 \\
\hline & Aug. 8,1945 & 10.7 & 4,230 \\
\hline \multirow[t]{3}{*}{1946} & Mar. 16,1946 & 11.5 & 5,160 \\
\hline & (Gage moved to new & on April 22, 1 & \\
\hline & May 28,1946 & 13.4 & 7,310 \\
\hline \multirow[t]{3}{*}{1947} & June 14,1947 & 12.4 & 5,780 \\
\hline & June 23,1947 & 22.3 & 29,100 \\
\hline & July $\quad 8,1947$ & 11.6 & 5,420 \\
\hline 1948 & Mar. 20, 1948 & 13.8 & 8,630 \\
\hline 1949 & Mar. 7,1949 & 14.8 & 10,100 \\
\hline \multirow[t]{2}{*}{1950} & June 19,1950 & 12.0 & 6,050 \\
\hline & June 23,1950 & 11.1 & 4,710 \\
\hline
\end{tabular}


05482500 North Raccoon River near Jefferson, Iowa

Peak stages and discharges--Continued

\begin{tabular}{|c|c|c|c|}
\hline Water year & Date & $\begin{array}{l}\text { Gage height } \\
\text { (ft) }\end{array}$ & $\begin{array}{c}\text { Discharge } \\
\left(\mathrm{ft}^{3} / \mathrm{s}\right)\end{array}$ \\
\hline \multirow[t]{7}{*}{1951} & Mar. 29,1951 & 17.39 & 16,000 \\
\hline & May 3,1951 & 15.62 & 11,800 \\
\hline & June 3,1951 & 12.88 & 6,720 \\
\hline & June 21,1951 & 12.25 & 5,800 \\
\hline & July $\quad 4,1951$ & 12.58 & 6,320 \\
\hline & Aug. 18, 1951 & 12.41 & 6,060 \\
\hline & Aug. 30,1951 & 12.97 & 6,860 \\
\hline \multirow[t]{2}{*}{1952} & Apr. $\quad 1,1952$ & 12.80 & 6,580 \\
\hline & July 11,1952 & 12.51 & 6,190 \\
\hline 1953 & July 1,1953 & 10.10 & 3,490 \\
\hline \multirow[t]{3}{*}{1954} & June 13,1954 & 11.09 & 4,670 \\
\hline & June 22,1954 & 19.52 & 21,300 \\
\hline & Aug. 29, 1954 & 14.19 & 9,360 \\
\hline 1955 & Apr. 26,1955 & 9.78 & 3,580 \\
\hline 1956 & May 13,1956 & 5.4 & 650 \\
\hline 1957 & June 16,1957 & 13.49 & 7,800 \\
\hline 1958 & June 7,1958 & 11.70 & 4,720 \\
\hline 1959 & June 3,1959 & 15.06 & 9,800 \\
\hline \multirow[t]{2}{*}{1960} & Mar. 31,1960 & 19.43 & 18,600 \\
\hline & May 28,1960 & 13.45 & 6,960 \\
\hline 1961 & Mar. 29, 1961 & 13.19 & 6,680 \\
\hline \multirow[t]{3}{*}{1962} & Mar. 30, 1962 & 17.60 & 14,300 \\
\hline & June 10,1962 & 11.90 & 5,050 \\
\hline & Sept. 4,1962 & 16.33 & 11,700 \\
\hline 1963 & May 14,1963 & 12.34 & 5,510 \\
\hline 1964 & May 8,1964 & 8.61 & 2,280 \\
\hline \multirow[t]{3}{*}{1965} & Apr. 5,1965 & 15.29 & 9,890 \\
\hline & May 27,1965 & 14.94 & 9,300 \\
\hline & Sept. 30,1965 & 12.38 & 5,610 \\
\hline \multirow[t]{2}{*}{1966} & June 12,1966 & 14.11 & 7,980 \\
\hline & June 28,1966 & 11.47 & 4,620 \\
\hline \multirow[t]{4}{*}{1967} & June 11,1967 & 15.61 & 10,400 \\
\hline & June 19,1967 & 15.61 & 10,400 \\
\hline & June 24,1967 & 12.04 & 5,200 \\
\hline & June 28,1967 & 11.75 & 4,900 \\
\hline 1968 & June 26,1968 & 9.05 & 2,620 \\
\hline \multirow[t]{7}{*}{1969} & Oct. 19,1968 & 11.06 & 4,160 \\
\hline & Mar. 26, 1969 & 15.85 & 10,800 \\
\hline & Apr. 7,1969 & 14.46 & 8,500 \\
\hline & Apr. 19,1969 & 11.06 & 4,200 \\
\hline & June 30,1969 & 12.88 & 6,110 \\
\hline & July 10,1969 & 13.72 & 7,410 \\
\hline & July 30,1969 & 12.16 & 5,220 \\
\hline
\end{tabular}


05482500 North Raccoon River near Jefferson, Iowa

Peak stages and discharges--Continued

\begin{tabular}{|c|c|c|c|}
\hline Water year & Date & $\begin{array}{c}\text { Gage height } \\
\text { (ft) }\end{array}$ & $\begin{array}{c}\text { Discharge } \\
\left(\mathrm{ft}^{3} / \mathrm{s}\right)\end{array}$ \\
\hline 1970 & May 16,1970 & $\mathrm{c}_{11.64}$ & 4,690 \\
\hline \multirow[t]{2}{*}{1971} & Feb. 21,1971 & ${ }^{\mathrm{a}} 15.75$ & $b_{6,300}$ \\
\hline & Mar. 15, 1971 & 13.70 & 7,160 \\
\hline 1972 & July 20,1972 & 12.25 & 5,550 \\
\hline \multirow[t]{14}{*}{1973} & Feb. 27,1973 & ${ }^{\mathrm{a}} 13.19$ & $b_{5,460}$ \\
\hline & Mar. 4,1973 & ${ }^{\mathrm{a}} 14.37$ & ${ }^{b} 7,370$ \\
\hline & Mar. 15,1973 & 13.34 & 6,720 \\
\hline & Mar. 27, 1973 & 11.64 & 4,940 \\
\hline & Apr. 13,1973 & 10.91 & 4,260 \\
\hline & Apr. 18,1973 & 12.56 & 6,030 \\
\hline & May 4,1973 & 11.29 & 4,720 \\
\hline & May 9,1973 & 13.42 & 6,940 \\
\hline & May 31,1973 & 12.78 & 6,170 \\
\hline & June 19,1973 & 10.95 & 4,260 \\
\hline & July 4,1973 & 15.11 & 9,060 \\
\hline & July 11,1973 & 12.38 & 5,680 \\
\hline & Aug. 26, 1973 & 11.13 & 4,150 \\
\hline & Sept. 29,1973 & 15.97 & 10,400 \\
\hline \multirow[t]{5}{*}{1974} & Oct. 14,1973 & 14.06 & 7,240 \\
\hline & Nov. 23,1973 & 12.04 & 5,340 \\
\hline & Feb. 20,1974 & ${ }^{\mathrm{a}} 15.11$ & $b_{5}, 900$ \\
\hline & May 16,1974 & 11.25 & 4,260 \\
\hline & May 18,1974 & 13.35 & 6,400 \\
\hline \multirow[t]{2}{*}{1975} & Apr. 28,1975 & 12.84 & 6,060 \\
\hline & May 1,1975 & 13.82 & 7,190 \\
\hline 1976 & May 24,1976 & 10.31 & 3,330 \\
\hline \multirow[t]{2}{*}{1977} & Feb. 23,1977 & "5.71 & -- \\
\hline & Aug. 26, 1977 & 5.29 & 404 \\
\hline \multirow[t]{3}{*}{1978} & July 10,1978 & 12.21 & 5,160 \\
\hline & Sept. 17,1978 & 14.67 & 8,200 \\
\hline & Sept. 21,1978 & 10.98 & 4,010 \\
\hline \multirow[t]{5}{*}{1979} & Mar. 20,1979 & 16.56 & 12,300 \\
\hline & Mar. 25, 1979 & 17.84 & 15,300 \\
\hline & Mar. 31,1979 & 17.5 & 14,500 \\
\hline & June 30,1979 & 13.3 & 7,000 \\
\hline & Aug. 26, 1979 & 11.38 & 4,800 \\
\hline 1980 & Apr. 5,1980 & 8.93 & 2,550 \\
\hline 1981 & June 29,1981 & 7.35 & 1,620 \\
\hline \multirow[t]{6}{*}{1982} & Mar. 21,1982 & 12.00 & 5,440 \\
\hline & May 5,1982 & 11.30 & 4,720 \\
\hline & May 6,1982 & 10.96 & 4,400 \\
\hline & May 29,1982 & 12.52 & 6,040 \\
\hline & June 15,1982 & 10.53 & 4,110 \\
\hline & July $\quad 9,1982$ & 10.61 & 4,190 \\
\hline
\end{tabular}




\section{North Raccoon River near Jefferson, Iowa}

Peak stages and discharges--Continued

\begin{tabular}{|c|c|c|c|}
\hline Water year & Date & $\begin{array}{c}\text { Gage height } \\
\text { (ft) }\end{array}$ & $\begin{array}{c}\text { Discharge } \\
\left(\mathrm{ft}^{3} / \mathrm{s}\right)\end{array}$ \\
\hline \multirow[t]{2}{*}{ 1982--Continued } & July 13,1982 & 10.96 & 4,490 \\
\hline & July 21,1982 & 12.91 & 6,540 \\
\hline \multirow[t]{9}{*}{1983} & Oct. 11,1982 & 10.91 & 4420 \\
\hline & Feb. 24,1983 & 12.80 & 6,690 \\
\hline & Mar. 9,1983 & 15.92 & 11,600 \\
\hline & Mar. 18,1983 & 12.16 & 5,970 \\
\hline & Apr. 3,1983 & 14.11 & 8,530 \\
\hline & Apr. 16,1983 & 14.33 & 8,850 \\
\hline & May 5,1983 & 13.16 & 7,210 \\
\hline & June 24,1983 & 16.39 & 12,500 \\
\hline & July 2,1983 & 17.38 & 14,500 \\
\hline \multirow[t]{9}{*}{1984} & Feb. 19,1984 & 12.05 & 5,790 \\
\hline & Apr. 6,1984 & 11.00 & 4,840 \\
\hline & Apr. 11,1984 & 12.38 & 6,320 \\
\hline & Apr. 25,1984 & 12.58 & 6,570 \\
\hline & May 1,1984 & 15.69 & 11,300 \\
\hline & May 31,1984 & 13.05 & 7,170 \\
\hline & June 11,1984 & 14.94 & 9,930 \\
\hline & June 17,1984 & 15.85 & 11,500 \\
\hline & June 21,1984 & 17.86 & 15,600 \\
\hline 1985 & Dec. 31,1984 & ${ }^{\mathrm{a}} 13.10$ & $\mathrm{~b}_{2,800}$ \\
\hline \multirow[t]{7}{*}{1986} & Mar. 21, 1986 & 14.01 & 8,260 \\
\hline & Apr. 7,1986 & 11.17 & 4,840 \\
\hline & May 1,1986 & 11.31 & 4,990 \\
\hline & May 13,1986 & 13.44 & 7,520 \\
\hline & June 30,1986 & 13.95 & 8,230 \\
\hline & Sept. 22, 1986 & 10.86 & 4,390 \\
\hline & Sept. 28,1986 & 10.47 & 4,010 \\
\hline \multirow[t]{5}{*}{1987} & Oct. 15,1986 & 14.03 & 8,840 \\
\hline & Apr. 17,1987 & 11.54 & 5,420 \\
\hline & May 28,1987 & 10.74 & 4,600 \\
\hline & July 15,1987 & 11.46 & 5,320 \\
\hline & Sept. 18,1987 & 10.56 & 4,250 \\
\hline \multirow[t]{2}{*}{1988} & Feb. 20,1988 & 7.08 & -- \\
\hline & May 10,1988 & 6.78 & 1,470 \\
\hline 1989 & May 24,1989 & 8.97 & 1,740 \\
\hline \multirow[t]{5}{*}{1990} & May 21,1990 & 12.22 & 6,160 \\
\hline & May 25,1990 & 13.88 & 8,370 \\
\hline & June 19,1990 & 18.61 & 18,400 \\
\hline & June 30,1990 & 12.09 & 6,250 \\
\hline & Aug. 27,1990 & 10.75 & 4,440 \\
\hline \multirow[t]{3}{*}{1991} & Mar. 26, 1991 & 12.58 & 6,820 \\
\hline & Apr. 17,1991 & 14.34 & 9,400 \\
\hline & Apr. 29,1991 & 14.15 & 9,080 \\
\hline
\end{tabular}




\section{North Raccoon River near Jefferson, Iowa}

Peak stages and discharges--Continued

\begin{tabular}{|c|c|c|c|}
\hline Water year & Date & $\begin{array}{c}\text { Gage height } \\
\text { (ft) }\end{array}$ & $\begin{array}{c}\text { Discharge } \\
\left(\mathrm{ft}^{3} / \mathrm{s}\right)\end{array}$ \\
\hline \multirow[t]{5}{*}{ 1991--Continued } & May 8,1991 & 14.04 & 8,890 \\
\hline & May 20,1991 & 13.60 & 8,190 \\
\hline & May 29,1991 & 11.46 & 5,480 \\
\hline & June 6,1991 & 16.60 & 13,600 \\
\hline & June 16,1991 & 14.15 & 9,610 \\
\hline \multirow[t]{2}{*}{1992} & Apr. 23,1992 & 12.25 & 6,400 \\
\hline & July 16,1992 & 11.12 & 5,200 \\
\hline \multirow[t]{10}{*}{1993} & Mar. 8,1993 & a-- & $\mathrm{b}_{5,700}$ \\
\hline & Apr. 2,1993 & 14.60 & 9,580 \\
\hline & Apr. 23,1993 & 15.13 & 10,400 \\
\hline & May 12,1993 & 15.21 & 10,500 \\
\hline & June 20,1993 & 13.09 & 7,480 \\
\hline & July 3,1993 & 14.07 & 8,820 \\
\hline & July 10,1993 & 19.20 & 16,900 \\
\hline & July 27,1993 & 11.63 & 5,600 \\
\hline & Aug. 19, 1993 & 14.39 & 9,280 \\
\hline & Sept. 1,1993 & 12.12 & 6,210 \\
\hline \multirow[t]{2}{*}{1994} & Mar. 5, 1994 & ${ }^{a} 11.93$ & -- \\
\hline & Mar. 6,1994 & 11.66 & 5,640 \\
\hline \multirow[t]{4}{*}{1995} & Apr. 23,1995 & 9.92 & 4,050 \\
\hline & May 11,1995 & 11.59 & 6,000 \\
\hline & May 15,1995 & 10.98 & 5,250 \\
\hline & May 30,1995 & 12.53 & 7,210 \\
\hline \multirow[t]{5}{*}{1996} & May 30,1996 & 10.23 & 4,020 \\
\hline & June 24,1996 & 16.16 & 11,900 \\
\hline & July 18,1996 & 12.66 & 6,910 \\
\hline & Aug. 7,1996 & 10.87 & 4,700 \\
\hline & Aug. 11, 1996 & 10.68 & 4,490 \\
\hline
\end{tabular}

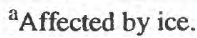

${ }^{\mathrm{b}}$ Approximate.

${ }^{\mathrm{c}} \mathrm{Gage}$ height determined from floodmark. 


\section{Hardin Creek at Farnhamville, Iowa}

(Discontinued September 30, 1991)

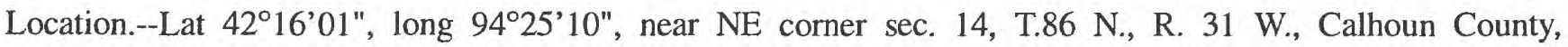
Hydrologic Unit 07100006, at bridge on State Highway 175, near west city limits of Farnhamville.

Drainage area.--43.7 $\mathrm{mi}^{2}$.

Gage.--Crest-stage gage.

Stage-discharge relation.--Defined by current-meter measurements.

Remarks.--Only annual peaks are shown.

Peak stages and discharges

[Water year, October 1 -September 30 ; $\mathrm{ft}$, feet above gage datum; $\mathrm{ft}^{3} / \mathrm{s}$, cubic feet per second; --, not determined]

\begin{tabular}{|c|c|c|c|}
\hline Water year & Date & $\begin{array}{c}\text { Gage height } \\
\text { (ft) }\end{array}$ & $\begin{array}{c}\text { Discharge } \\
\left(\mathrm{ft}^{3} / \mathrm{s}\right)\end{array}$ \\
\hline 1952 & Mar. 29, 1952 & 8.09 & 318 \\
\hline 1953 & July 14,1953 & 8.44 & 429 \\
\hline 1954 & Aug. 26, 1954 & 10.48 & 2,000 \\
\hline 1955 & Mar. 11, 1955 & 8.76 & 557 \\
\hline 1956 & Mar. 21, 1956 & 6.78 & 118 \\
\hline 1957 & June 16,1957 & 7.90 & 270 \\
\hline 1958 & June 7,1958 & 7.69 & 225 \\
\hline 1959 & June 1,1959 & 9.06 & 700 \\
\hline 1960 & Mar. 29, 1960 & 9.75 & 840 \\
\hline 1961 & Sept. 30,1961 & 7.91 & 272 \\
\hline 1962 & July 14,1962 & 9.20 & 812 \\
\hline 1963 & May 13,1963 & 9.55 & 995 \\
\hline 1964 & Apr. 13,1964 & 8.54 & 466 \\
\hline 1965 & May 26,1965 & 9.78 & 1,110 \\
\hline 1966 & May 23,1966 & 7.93 & 277 \\
\hline 1967 & June 13,1967 & 9.34 & 854 \\
\hline 1968 & June 25,1968 & 8.79 & 570 \\
\hline 1969 & July 26,1969 & 10.45 & 1,960 \\
\hline 1970 & -- & i.- & j90 \\
\hline 1971 & Mar. 12,1971 & à 9.38 & $\mathrm{~b}_{480}$ \\
\hline 1972 & Oct. 31,1971 & 9.09 & 700 \\
\hline 1973 & Mar. 17, 1973 & 9.27 & 820 \\
\hline 1974 & June 22,1974 & 8.82 & 570 \\
\hline 1975 & Apr. 26,1975 & 9.56 & 1,000 \\
\hline 1976 & -- & i-- & j90 \\
\hline 1977 & Aug. 21, 1977 & 7.85 & 250 \\
\hline 1978 & -- & i.- & j90 \\
\hline 1979 & Mar. 19, 1979 & 10.29 & 1,850 \\
\hline 1980 & -- & i-- & j90 \\
\hline 1981 & July $\quad 3,1981$ & 8.00 & 255 \\
\hline
\end{tabular}




\section{Hardin Creek at Farnhamville, Iowa}

Peak stage and discharges--Continued

\begin{tabular}{|c|c|c|c|}
\hline Water year & Date & $\begin{array}{l}\text { Gage height } \\
\text { (ft) }\end{array}$ & $\begin{array}{c}\text { Discharge } \\
\left(\mathrm{ft}^{3} / \mathrm{s}\right)\end{array}$ \\
\hline 1982 & May 4,1982 & 8.95 & 580 \\
\hline 1983 & June 28,1983 & 9.90 & 1,300 \\
\hline 1984 & June 21,1984 & 9.97 & 900 \\
\hline 1985 & -- & i-. & $\mathrm{j}_{88}$ \\
\hline 1986 & May 10,1986 & 9.09 & 430 \\
\hline 1987 & Oct. 11,1986 & 9.17 & 450 \\
\hline 1988 & -- & i-- & $\mathrm{j}_{87}$ \\
\hline 1989 & -- & i-- & $j_{87}$ \\
\hline 1990 & June 16,1990 & 10.39 & 1,980 \\
\hline 1991 & -- & -- & -- \\
\hline
\end{tabular}

aAffected by ice.

${ }^{\text {bApproximate. }}$

'Peak did not reach bottom of gage.

${ }^{\mathrm{j}}$ Discharge less than indicated value. 


\section{Happy Run at Churdan, Iowa}

(Discontinued September 1989)

Location.--Lat $42^{\circ} 10^{\prime} 16^{\prime \prime}$, long 94²9’39", in SW1/4 sec. 17, T.85 N., R.31 W., Greene County, Hydrologic Unit 07100006 , at bridge on county road, 1 mi northwest of Churdan.

Drainage area.--7.58 $\mathrm{mi}^{2}$.

Gage.--Crest-stage gage.

Stage-discharge relation.--Defined by current-meter measurements and above $100 \mathrm{ft}^{3} / \mathrm{s}$ by rating-curve extension.

Remarks.--Only annual peaks are shown.

Peak stages and discharges

[Water year, October 1-September 30; $\mathrm{ft}$, feet above gage datum; $\mathrm{ft}^{3} / \mathrm{s}$, cubic feet per second; --, not determined]

\begin{tabular}{|c|c|c|c|}
\hline Water year & Date & $\begin{array}{c}\text { Gage height } \\
\text { (ft) }\end{array}$ & $\begin{array}{c}\text { Discharge } \\
\left(\mathrm{ft}^{3} / \mathrm{s}\right)\end{array}$ \\
\hline 1951 & Mar. 29,1951 & 7.72 & 110 \\
\hline 1952 & Mar. 19,1952 & 6.25 & 54 \\
\hline 1953 & - & i.. & $\mathrm{j}_{19}$ \\
\hline 1954 & Aug. 26, 1954 & 7.87 & 116 \\
\hline 1955 & July 10,1955 & 7.80 & 113 \\
\hline 1956 & -- & i.. & $j_{19}$ \\
\hline 1957 & June 17,1957 & 7.81 & $k_{81}$ \\
\hline 1958 & -- & i-- & $\mathrm{j}_{19}$ \\
\hline 1959 & June 1,1959 & 7.70 & 77 \\
\hline 1960 & May 6,1960 & 6.50 & 48 \\
\hline 1961 & Sept. 30, 1961 & 6.42 & $k_{62}$ \\
\hline 1962 & Mar. 25, 1962 & 8.57 & 150 \\
\hline 1963 & - & i.. & $\mathrm{j}_{19}$ \\
\hline 1964 & Apr. 13,1964 & 7.27 & 61 \\
\hline 1965 & Sept. 27,1965 & 7.77 & ${ }^{k} 108$ \\
\hline 1966 & June 12,1966 & 7.36 & 64 \\
\hline 1967 & June 13,1967 & 9.37 & $\mathrm{~b}_{180}$ \\
\hline 1968 & -- & i... & $\mathbf{j}_{19}$ \\
\hline 1969 & Mar. 26, 1969 & 6.29 & 60 \\
\hline 1970 & - & i.- & $\mathrm{j}, \mathrm{k}_{25}$ \\
\hline 1971 & Mar. 12,1971 & 6.74 & 79 \\
\hline 1972 & - & i.- & $\mathrm{j}, \mathrm{k}_{25}$ \\
\hline 1973 & Apr. 28,1973 & 4.87 & 36 \\
\hline 1974 & - & i-. & $\mathrm{j}, \mathrm{k} 25$ \\
\hline 1975 & - & i.. & $\mathrm{j}, \mathrm{k} 25$ \\
\hline 1976 & -- & i.. & $\mathrm{j}, \mathrm{k}_{25}$ \\
\hline 1977 & Aug. 21,1977 & 4.49 & 30 \\
\hline 1978 & -- & $i_{-}$ & $\mathrm{j}, \mathrm{k} 25$ \\
\hline 1979 & Mar. 19,1979 & 9.36 & $\mathrm{~b}_{180}$ \\
\hline 1980 & -- & i-_ & $\mathrm{j}_{25}$ \\
\hline
\end{tabular}




\section{Happy Run at Churdan, Iowa}

Peak stages and discharges--Continued

\begin{tabular}{|c|c|c|c|}
\hline Water year & Date & $\begin{array}{l}\text { Gage height } \\
\text { (ft) }\end{array}$ & $\begin{array}{c}\text { Discharge } \\
\left(\mathrm{ft}^{3} / \mathrm{s}\right)\end{array}$ \\
\hline 1981 & July 3,1981 & 5.64 & $\mathrm{k}_{51}$ \\
\hline 1982 & May 4,1982 & 6.41 & $\mathrm{k}_{70}$ \\
\hline 1983 & Feb. 20,1983 & 5.01 & $k_{38}$ \\
\hline 1984 & May 1,1984 & 4.21 & $\mathrm{k}_{26}$ \\
\hline 1985 & -- & i-. & $\mathrm{j}_{25}$ \\
\hline 1986 & May 10,1986 & 5.52 & $\mathrm{k}_{48}$ \\
\hline 1987 & -- & i-- & $\mathrm{j}_{25}$ \\
\hline 1988 & -- & i-- & $\mathrm{j}_{25}$ \\
\hline 1989 & -- & i - & $\mathrm{j}_{25}$ \\
\hline
\end{tabular}

\footnotetext{
${ }^{\mathrm{b}}$ Approximate.
}

iPeak did not reach bottom of gage.

${ }^{J}$ Discharge less than indicated value.

${ }^{k_{k}}$ Revised from previously published value. 


\section{Hardin Creek near Farlin, Iowa}

Location.--Lat 42 $05^{\prime} 34^{\prime \prime}$, long 94'25'39", in NW1/4 sec. 14, T.84 N., R.31 W., Greene County, Hydrologic Unit 07100006 , at bridge on county road, 1.5 mi northeast of Farlin.

Drainage area.--101 $\mathrm{mi}^{2}$.

Gage.--Crest-stage gage.

Stage-discharge relation.--Defined by current-meter and indirect measurements.

Remarks.--Only annual peaks are shown.

Peak stages and discharges

[Water year, October 1-September 30; $\mathrm{ft}$, feet above gage datum; $\mathrm{ft}^{3} / \mathrm{s}$, cubic feet per second; --, not determined]

\begin{tabular}{|c|c|c|c|}
\hline Water year & Date & $\begin{array}{c}\text { Gage height } \\
\text { (ft) }\end{array}$ & $\begin{array}{c}\text { Discharge } \\
\left(\mathrm{ft}^{3} / \mathrm{s}\right)\end{array}$ \\
\hline 1951 & Mar. 29,1951 & 12.97 & 2,270 \\
\hline 1952 & Mar. 29, 1952 & 9.11 & 472 \\
\hline 1953 & July 14,1953 & 7.96 & 300 \\
\hline 1954 & Aug. 27, 1954 & 12.57 & 1,810 \\
\hline 1955 & July 10,1955 & 10.03 & 631 \\
\hline 1956 & - & i-- & $\mathrm{j}_{120}$ \\
\hline 1957 & June 17,1957 & 10.59 & 743 \\
\hline 1958 & -- & i.- & ${ }^{\mathrm{j}} 120$ \\
\hline 1959 & June 1,1959 & 11.40 & 980 \\
\hline 1960 & Mar. 29, 1960 & 13.32 & 1,960 \\
\hline 1961 & Mar. 27, 1961 & 8.82 & 324 \\
\hline 1962 & Mar. 26, 1962 & 12.48 & 2,000 \\
\hline 1963 & May 13,1963 & 10.87 & 930 \\
\hline 1964 & Apr. 13, 1964 & 9.39 & 615 \\
\hline 1965 & Sept. 21,1965 & 9.79 & 703 \\
\hline 1966 & June 12,1966 & 9.13 & 474 \\
\hline 1967 & June 13,1967 & 10.95 & 1,020 \\
\hline 1968 & -- & i.- & $j_{300}$ \\
\hline 1969 & July 26,1969 & 12.17 & 1,950 \\
\hline 1970 & -- & i.- & $j_{300}$ \\
\hline 1971 & Mar. 12,1971 & ${ }^{\mathrm{a}} 12.37$ & ${ }^{b} 1,110$ \\
\hline 1972 & May 6,1972 & 9.04 & 570 \\
\hline 1973 & Mar. 18,1973 & 11.32 & 960 \\
\hline 1974 & May 28,1974 & 9.79 & 700 \\
\hline 1975 & -- & i.. & $\mathrm{j} 300$ \\
\hline 1976 & -- & i.- & $j_{300}$ \\
\hline 1977 & -- & i... & $\mathrm{j}_{300}$ \\
\hline 1978 & Mar. 16,1978 & 9.26 & 510 \\
\hline 1979 & Mar. 19, 1979 & 12.69 & 2,330 \\
\hline 1980 & -- & i.- & $j_{300}$ \\
\hline 1981 & -- & i.- & $\mathrm{j}_{300}$ \\
\hline 1982 & May 4,1982 & 9.84 & 768 \\
\hline
\end{tabular}




\section{Hardin Creek near Farlin, Iowa}

Peak stages and discharges--Continued

\begin{tabular}{|c|c|c|c|}
\hline Water year & Date & $\begin{array}{l}\text { Gage height } \\
\text { (ft) }\end{array}$ & $\begin{array}{c}\text { Discharge } \\
\left(\mathrm{ft}^{3} / \mathrm{s}\right)\end{array}$ \\
\hline 1983 & Feb. 19,1983 & 10.15 & 835 \\
\hline 1984 & Apr. 30,1984 & 9.55 & 708 \\
\hline 1985 & -- & i... & $\mathrm{j}_{479}$ \\
\hline 1986 & May 10,1986 & 9.64 & 726 \\
\hline 1987 & Oct. 12,1986 & 11.29 & 1,210 \\
\hline 1988 & -- & i.- & $\mathrm{j}_{479}$ \\
\hline 1989 & -- & i-. & $\mathrm{j}_{479}$ \\
\hline 1990 & June 16,1990 & 12.89 & 2,470 \\
\hline 1991 & June $\quad 1,1991$ & 13.02 & 2,630 \\
\hline 1992 & Apr. 23, 1992 & 9.53 & 600 \\
\hline 1993 & July 9,1993 & 13.97 & 3,010 \\
\hline 1994 & -- & -- & -- \\
\hline 1995 & -- & i.. & $\mathrm{j}_{435}$ \\
\hline 1996 & July 17,1996 & 9.00 & 600 \\
\hline
\end{tabular}

${ }^{a}$ Affected by ice.

${ }^{\mathrm{b}}$ Approximate.

${ }^{\text {i }}$ Peak did not reach bottom of gage.

${ }^{\mathrm{j}}$ Discharge less than indicated value. 


\section{East Fork Hardin Creek near Paton, Iowa}

(Discontinued September 1955)

Location.--Lat $42^{\circ} 08^{\prime} 15^{\prime \prime}$, long $91^{\circ} 23^{\prime} 00^{\prime}$, near S1/4 corner, sec. 20, T.85 N., R.30 W., Greene County, Hydrologic Unit 07100006, at bridge on County Road H, 6 mi west of Paton.

Drainage area.--7.57 $\mathrm{mi}^{2}$.

Gage.--Crest-stage gage.

Stage-discharge relation.--Defined by current-meter measurements.

Remarks.--Only annual peaks are shown.

Peak stages and discharges

[Water year, October 1-September 30; ft, feet above gage datum; $\mathrm{ft}^{3} / \mathrm{s}$, cubic feet per second; --, not determined]

\begin{tabular}{cccc}
\hline Water year & Date & $\begin{array}{c}\text { Gage height } \\
\text { (ft) }\end{array}$ & $\begin{array}{c}\text { Discharge } \\
\left(\mathbf{f t}^{3} / \mathbf{s}\right)\end{array}$ \\
\hline 1952 & July 7,1952 & 4.72 & 39 \\
1953 & Mar. 24, 1953 & 7.77 & 68 \\
1954 & Aug. 26, 1954 & 7.00 & 60 \\
1955 & July 10, 1955 & 7.37 & 64 \\
\hline
\end{tabular}




\section{East Fork Hardin Creek near Churdan, Iowa}

(Discontinued September 30, 1991)

Location.--Lat 42 06'27", long 94'22'12", in SE1/4 SW1/4 sec. 5, T.84 N., R.30 W., Greene County, Hydrologic Unit 07100006 , on left bank $35 \mathrm{ft}$ upstream from bridge on County Road E26, $1.6 \mathrm{mi}$ upstream from small left-bank tributary, $4.4 \mathrm{mi}$ upstream from mouth, and $6.5 \mathrm{mi}$ southeast of Churdan.

Drainage area.--24.0 $\mathrm{mi}^{2}$.

Gage.--Water-stage recorder. Datum is $1,050.90 \mathrm{ft}$ above sea level.

Stage-discharge relation.--Defined by current-meter measurements and above $180 \mathrm{ft}^{3} / \mathrm{s}$ by theoretical rating-curve extension techniques.

Bankfull stage.--High banks are not subject to overflow.

Remarks.--Base for partial-duration series, $150 \mathrm{ft}^{3} / \mathrm{s}$; prior to 1962 , peak base was $200 \mathrm{ft}^{3} / \mathrm{s}$.

Peak stages and discharges

[Water year, October 1-September 30; $\mathrm{ft}$, feet above gage datum; $\mathrm{ft}^{3} / \mathrm{s}$, cubic feet per second; --, not determined]

\begin{tabular}{|c|c|c|c|}
\hline Water year & Date & $\begin{array}{c}\text { Gage height } \\
\text { (ft) }\end{array}$ & $\begin{array}{c}\text { Discharge } \\
\left(\mathrm{ft}^{3} / \mathrm{s}\right)\end{array}$ \\
\hline \multicolumn{4}{|c|}{ (Systematic operation of gage began July 1,1952 .) } \\
\hline 1952 & July 14,1952 & 4.33 & ${ }^{1} 79$ \\
\hline 1953 & June 10,1953 & 5.17 & 105 \\
\hline 1954 & Aug. 26, 1954 & 7.73 & 329 \\
\hline \multirow[t]{2}{*}{1955} & Oct. 13,1954 & 6.15 & 250 \\
\hline & July 10,1955 & 6.60 & 252 \\
\hline 1956 & May 13,1956 & 4.42 & 112 \\
\hline \multirow[t]{2}{*}{1957} & June 14,1957 & 6.57 & 216 \\
\hline & June 16,1957 & 8.82 & 371 \\
\hline 1958 & July 19,1958 & 6.10 & 186 \\
\hline 1959 & May 31,1959 & 7.36 & 288 \\
\hline \multirow[t]{4}{*}{1960} & Mar. 29, 1960 & ${ }^{a} 7.63$ & $\mathrm{~b}_{300}$ \\
\hline & Apr. 24,1960 & 8.04 & 350 \\
\hline & May 5,1960 & 8.92 & 413 \\
\hline & May 25,1960 & 6.30 & 231 \\
\hline 1961 & Feb. 22, 1961 & ${ }^{a} 5.41$ & $b_{150}$ \\
\hline \multirow[t]{4}{*}{1962} & Mar. 25, 1962 & 6.06 & 231 \\
\hline & May 29,1962 & 5.20 & 160 \\
\hline & July 14,1962 & 7.46 & 315 \\
\hline & July 20,1962 & 5.42 & 173 \\
\hline 1963 & Apr. 29,1963 & 7.78 & $b_{300}$ \\
\hline \multirow[t]{2}{*}{1964} & Apr. 13,1964 & 5.36 & 172 \\
\hline & Apr. 27,1964 & 5.18 & 159 \\
\hline \multirow[t]{3}{*}{1965} & Mar. 31,1965 & ${ }^{\mathrm{a}} 8.28$ & $b_{300}$ \\
\hline & Apr. $\quad 5,1965$ & 6.13 & 214 \\
\hline & Sept. 27,1965 & 5.45 & 170 \\
\hline
\end{tabular}




\section{East Fork Hardin Creek near Churdan, Iowa}

Peak stages and discharges--Continued

\begin{tabular}{|c|c|c|c|}
\hline Water year & Date & $\begin{array}{c}\text { Gage height } \\
\text { (ft) }\end{array}$ & $\begin{array}{c}\text { Discharge } \\
\left(\mathrm{ft}^{3} / \mathrm{s}\right)\end{array}$ \\
\hline \multirow[t]{2}{*}{1966} & June 12,1966 & 8.32 & 367 \\
\hline & June 27,1966 & 6.27 & 180 \\
\hline \multirow[t]{6}{*}{1967} & June $\quad 9,1967$ & 6.40 & 235 \\
\hline & June 13,1967 & 6.83 & 265 \\
\hline & June 16,1967 & 5.57 & 179 \\
\hline & June 19,1967 & 5.21 & 157 \\
\hline & June 24,1967 & 5.80 & 193 \\
\hline & June 27,1967 & 6.70 & 256 \\
\hline 1968 & June 25,1968 & 4.13 & 77 \\
\hline \multirow[t]{7}{*}{1969} & Oct. 17,1968 & 6.15 & 191 \\
\hline & Mar. 19,1969 & 6.83 & 297 \\
\hline & Mar. 24, 1969 & 6.34 & 248 \\
\hline & May 5,1969 & 5.97 & 215 \\
\hline & June 29,1969 & 6.34 & 201 \\
\hline & July $\quad 9,1969$ & 7.46 & 306 \\
\hline & July 26,1969 & 6.46 & 211 \\
\hline 1970 & May 14,1970 & 3.89 & 70 \\
\hline 1971 & Feb. 19,1971 & 7.86 & $b_{200}$ \\
\hline \multirow[t]{2}{*}{1972} & Mar. 6,1972 & $\mathrm{a}_{5} .86$ & $b_{160}$ \\
\hline & Aug. 1,1972 & 5.72 & 195 \\
\hline \multirow[t]{8}{*}{1973} & Feb. 24,1973 & $a_{-}$ & $b_{157}$ \\
\hline & Mar. 1,1973 & $a_{-}$ & $b_{152}$ \\
\hline & Mar. 11,1973 & 5.74 & 208 \\
\hline & Apr. 15,1973 & 5.78 & 199 \\
\hline & May 7,1973 & 5.95 & 205 \\
\hline & July $\quad 2,1973$ & 6.46 & 248 \\
\hline & Aug. 23,1973 & 5.58 & 177 \\
\hline & Sept. 26,1973 & 8.26 & 385 \\
\hline \multirow[t]{5}{*}{1974} & Oct. 11,1973 & 5.65 & 197 \\
\hline & Feb. 17,1974 & 5.25 & 159 \\
\hline & May 13,1974 & 5.58 & 206 \\
\hline & May 16,1974 & 6.13 & 243 \\
\hline & May 18,1974 & 7.71 & 385 \\
\hline \multirow[t]{2}{*}{1975} & Mar. 18,1975 & ${ }^{\mathrm{a}} 6.83$ & -- \\
\hline & Apr. 28,1975 & 5.39 & 195 \\
\hline 1976 & May 23,1976 & 5.11 & 148 \\
\hline 1977 & Sept. 30,1977 & 6.02 & 197 \\
\hline \multirow[t]{3}{*}{1978} & July $\quad 9,1978$ & 5.64 & 180 \\
\hline & Sept. 13,1978 & 7.59 & 225 \\
\hline & Sept. 20,1978 & 5.88 & 191 \\
\hline 1979 & Mar. 19,1979 & 7.46 & 376 \\
\hline 1980 & June 4,1980 & 5.62 & 179 \\
\hline \multirow[t]{2}{*}{1981} & July $\quad 4,1981$ & 6.86 & 207 \\
\hline & Aug. 26, 1981 & 6.19 & 169 \\
\hline
\end{tabular}




\section{East Fork Hardin Creek near Churdan, Iowa}

Peak stages and discharges--Continued

\begin{tabular}{|c|c|c|c|}
\hline Water year & Date & $\begin{array}{c}\text { Gage height } \\
\text { (ft) }\end{array}$ & $\begin{array}{c}\text { Discharge } \\
\left(\mathrm{ft}^{3} / \mathrm{s}\right)\end{array}$ \\
\hline \multirow[t]{5}{*}{1982} & Feb. 21,1982 & 7.12 & 237 \\
\hline & May 4,1982 & 7.16 & 282 \\
\hline & May 21,1982 & 5.62 & 175 \\
\hline & May 26,1982 & 5.28 & 155 \\
\hline & July 18,1982 & 5.34 & 158 \\
\hline \multirow[t]{3}{*}{1983} & ${ }^{m}$ Feb. $\quad 1983$ & $\mathrm{c}_{5.59}$ & 173 \\
\hline & Mar. 6,1983 & 5.94 & 194 \\
\hline & June 29,1983 & 7.45 & 237 \\
\hline \multirow[t]{4}{*}{1984} & Feb. $\quad 5,1984$ & 5.32 & 187 \\
\hline & Apr. 29,1984 & 7.10 & 331 \\
\hline & June 13,1984 & 4.93 & 158 \\
\hline & June 16,1984 & 4.98 & 162 \\
\hline 1985 & June 2,1985 & 4.20 & 110 \\
\hline \multirow[t]{2}{*}{1986} & June 11,1986 & 5.73 & 197 \\
\hline & June 30,1986 & ${ }^{c} 10.78$ & 737 \\
\hline \multirow[t]{3}{*}{1987} & Oct. 11,1986 & 6.17 & 260 \\
\hline & July 12,1987 & 5.83 & 152 \\
\hline & Aug. 26,1987 & 5.05 & 171 \\
\hline \multirow[t]{2}{*}{1988} & Dec. 9,1987 & 2.64 & 37 \\
\hline & Jan. 27,1988 & $a_{3.29}$ & -- \\
\hline 1989 & June 27,1989 & 3.81 & 82 \\
\hline \multirow[t]{7}{*}{1990} & May 19,1990 & 7.16 & 305 \\
\hline & May 25,1990 & 6.53 & 241 \\
\hline & June 13,1990 & 5.66 & 164 \\
\hline & June 17,1990 & 10.20 & 754 \\
\hline & July 13,1990 & 5.20 & 150 \\
\hline & July 26,1990 & 7.82 & 406 \\
\hline & Aug. 25,1990 & 6.28 & 249 \\
\hline \multirow[t]{7}{*}{1991} & Mar. 23,1991 & 5.52 & 208 \\
\hline & Mar. 27, 1991 & 5.63 & 216 \\
\hline & Apr. 14,1991 & 6.49 & 288 \\
\hline & Apr. 18,1991 & 5.16 & 179 \\
\hline & Apr. 26,1991 & 7.08 & 343 \\
\hline & May 17,1991 & 6.92 & 327 \\
\hline & June 4,1991 & 5.87 & 233 \\
\hline
\end{tabular}

${ }^{a}$ Affected by ice

${ }^{\mathrm{b}}$ Approximate.

${ }^{c}$ Gage height determined from floodmark.

${ }^{1}$ Peak for 1952 is from July 1 to September 30.

mPeak occurred sometime during February 19-21, 1983. 


\section{Brushy Creek near Templeton, Iowa}

Location.--Lat $41^{\circ} 56^{\prime} 45^{\prime \prime}$, long $94^{\circ} 52^{\prime} 45^{\prime \prime}$, in NW1/4 sec. 1, T.82 N., R.35 W., Carroll County, Hydrologic Unit 07100007 , at bridge on U.S. Highway 71,4 mi northeast of Templeton.

Drainage area.--45.0 $\mathrm{mi}^{2}$.

Gage.--Crest-stage gage. Datum is $1186.30 \mathrm{ft}$ above sea level. Prior to July 9, 1993, at present site at different datum.

Stage-discharge relation.--Prior to 1993 flood, defined by current-meter and indirect measurements; not defined for new bridge.

Remarks.--Only annual peaks are shown.

Peak stages and discharges

[Water year, October 1-September 30; $\mathrm{ft}$, feet above gage datum; $\mathrm{ft}^{3} / \mathrm{s}$, cubic feet per second; --, not determined]

\begin{tabular}{|c|c|c|c|}
\hline Water year & Date & $\begin{array}{l}\text { Gage height } \\
\text { (ft) }\end{array}$ & $\begin{array}{c}\text { Discharge } \\
\left(\mathrm{ft}^{3} / \mathrm{s}\right)\end{array}$ \\
\hline 1966 & June 12,1966 & 88.62 & 3,400 \\
\hline 1967 & June 7,1967 & 88.70 & 3,450 \\
\hline 1968 & - & i... & $\mathrm{j}_{700}$ \\
\hline 1969 & July 26,1969 & 86.99 & 2,400 \\
\hline 1970 & May 13,1970 & 83.91 & 1,060 \\
\hline 1971 & Mar. 13,1971 & a 87.78 & -- \\
\hline 1972 & Oct. 30,1971 & 86.48 & 2,100 \\
\hline 1973 & Sept. 26,1973 & 88.62 & 3,400 \\
\hline 1974 & June 23,1974 & 90.96 & ${ }^{n_{5}, 330}$ \\
\hline 1975 & Apr. 27,1975 & 85.72 & 1,880 \\
\hline 1976 & -- & i.- & j940 \\
\hline 1977 & -- & i.. & $\mathrm{j}_{1,080}$ \\
\hline 1978 & Sept. 12,1978 & 87.56 & $\mathbf{k}_{3,640}$ \\
\hline 1979 & Mar. 19,1979 & 86.58 & 3,210 \\
\hline 1980 & -- & i.. & $\mathrm{j}_{1,480}$ \\
\hline 1981 & -- & $i_{--}$ & $\mathrm{j}_{1,480}$ \\
\hline 1982 & May 26,1982 & 85.60 & 2,600 \\
\hline 1983 & -- & i-- & $\mathrm{j}_{1,480}$ \\
\hline 1984 & June 13,1984 & 83.89 & 1,960 \\
\hline 1985 & -- & i-. & ${ }^{\mathrm{j}} 1,480$ \\
\hline 1986 & June 30,1986 & 88.60 & 4,840 \\
\hline 1987 & -- & i-- & $\mathrm{j}_{1,480}$ \\
\hline 1988 & June 8,1988 & 87.82 & $n_{4,100}$ \\
\hline 1989 & Sept. 8,1989 & 78.64 & 400 \\
\hline 1990 & June 16,1990 & 90.58 & 7,550 \\
\hline 1991 & - & i- & $\mathrm{j}_{1,480}$ \\
\hline 1992 & - & i- & $\mathrm{j}_{400}$ \\
\hline
\end{tabular}




\section{Brushy Creek near Templeton, Iowa}

Peak stages and discharges--Continued

\begin{tabular}{cccc}
\hline Water year & Date & $\begin{array}{c}\text { Gage height } \\
(\mathrm{ft})\end{array}$ & $\begin{array}{c}\text { Discharge } \\
\left(\mathrm{ft}^{3} / \mathrm{s}\right)\end{array}$ \\
\hline 1993 & July $\quad 9,1993$ & 93.48 & ${ }^{\mathrm{n}} 19,000$ \\
& (Bridge destroyed by July 1993 flood.) & b,c,081.63 \\
1996 & July 17,1996 & - \\
& (Gage reinstalled on new bridge Sept. 16, 1996, at new datum.) & \\
\hline
\end{tabular}

${ }^{a}$ Affected by ice.

${ }^{c}$ Gage height determined from floodmark.

${ }^{\text {i }}$ Peak did not reach bottom of gage.

${ }^{\mathrm{j}}$ Discharge less than indicated value.

${ }^{\mathrm{k}}$ Revised from previously published value.

${ }^{n}$ Discharge computed from indirect measurement.

${ }^{0}$ Gage height for July 17,1996 , flood was referenced to the new datum established for the site. 


\section{Hazelbrush Creek near Maple River, Iowa}

(Discontinued September 30, 1994)

Location.--Lat $42^{\circ} 07^{\prime} 36^{\prime \prime}$, long 94 $58^{\prime} 32^{\prime \prime}$, in SW1/4 SW1/4 sec. 31, T.85 N., R.35 W., Carroll County, Hydrologic Unit 07100007 , on right bank 0.26 mi upstream from bridge on 160th Street, 0.40 mi upstream from mouth, and $2.9 \mathrm{mi}$ northeast of Maple River.

Drainage area.--9.22 $\mathrm{mi}^{2}$.

Gage.--Water-stage recorder and crest-stage gage. Datum of gage is $1,268.17 \mathrm{ft}$ above sea level.

Remarks.--Only annual peaks are shown.

Peak stages and discharges

[Water year, October 1-September 30; $\mathrm{ft}$, feet above gage datum; $\mathrm{ft}^{3} / \mathrm{s}$, cubic feet per second; --, not determined]

\begin{tabular}{cccc}
\hline Water year & Date & $\begin{array}{c}\text { Gage height } \\
(\mathbf{f t})\end{array}$ & $\begin{array}{c}\text { Discharge } \\
\left(\mathbf{f t}^{3} / \mathbf{s}\right)\end{array}$ \\
\hline 1991 & June 15,1991 & 13.59 & 957 \\
1992 & Dec. 12,1991 & 4.31 & 68.0 \\
1993 & July 9,1993 & 14.77 & 1,120 \\
1994 & Mar. 3, 1994 & ${ }^{a} 6.14$ & ${ }^{b} 114$ \\
\hline
\end{tabular}

${ }^{\mathrm{a} A f f e c t e d}$ by ice.

${ }^{\mathrm{b}}$ Approximate. 


\section{Middle Raccoon River tributary at Carroll, Iowa}

Location.--Lat $42^{\circ} 02^{\prime} 30^{\prime \prime}$, long 94'52'43", in NW1/4 sec. 36, T.84 N., R.35 W., Carroll County, Hydrologic Unit 07100007 , at bridge on U.S. Highway 71, $1.5 \mathrm{mi}$ south of Carroll.

Drainage area.--6.58 $\mathrm{mi}^{2}$.

Gage.--Crest-stage gage.

Stage-discharge relation.--Defined by current-meter and indirect measurements.

Remarks.--Only annual peaks are shown.

\section{Peak stages and discharges}

[Water year, October 1-September 30; ft, feet above gage datum; $\mathrm{ft}^{3} / \mathrm{s}$, cubic feet per second; --, not determined]

\begin{tabular}{|c|c|c|c|}
\hline Water year & Date & $\begin{array}{c}\text { Gage height } \\
\text { (ft) }\end{array}$ & $\begin{array}{c}\text { Discharge } \\
\left(\mathrm{ft}^{3} / \mathrm{s}\right)\end{array}$ \\
\hline 1966 & June 12,1966 & 90.12 & 500 \\
\hline 1967 & June 27,1967 & 90.45 & 550 \\
\hline 1968 & June 25,1968 & 89.69 & 440 \\
\hline 1969 & July 26,1969 & 90.37 & 540 \\
\hline 1970 & - & i.. & j 80 \\
\hline 1971 & Mar. 13,1971 & a89.64 & $\mathrm{b}_{400}$ \\
\hline 1972 & Sept. 12,1972 & 87.67 & 200 \\
\hline 1973 & July 1,1973 & 90.58 & 580 \\
\hline 1974 & -- & $i_{-}$ & $\mathrm{j}_{80}$ \\
\hline 1975 & Apr. 27,1975 & 90.34 & 530 \\
\hline 1976 & May 23,1976 & 91.06 & 680 \\
\hline 1977 & -- & i... & j80 \\
\hline 1978 & -- & i-. & j80 \\
\hline 1979 & -- & i-. & j80 \\
\hline 1980 & Mar. 20, 1980 & 19.66 & 168 \\
\hline 1981 & June 29,1981 & 22.83 & 694 \\
\hline 1982 & Mar. 19,1982 & 23.07 & 810 \\
\hline 1983 & June 27,1983 & 22.76 & 667 \\
\hline 1984 & June 13,1984 & 22.91 & 726 \\
\hline 1985 & -- & i-. & $j_{36}$ \\
\hline 1986 & June 29,1986 & 24.81 & ${ }^{n} 3,350$ \\
\hline 1987 & Aug. 12,1987 & 24.68 & 3,130 \\
\hline 1988 & June 8,1988 & 22.07 & 439 \\
\hline 1989 & June 12,1989 & 23.57 & 1,060 \\
\hline 1990 & June 13,1990 & 23.97 & 1,580 \\
\hline 1991 & -- & i-. & $\mathrm{j}, \mathrm{k} 89$ \\
\hline 1992 & -- & i-- & j89 \\
\hline 1993 & July $\quad 9,1993$ & 25.79 & $k_{4,490}$ \\
\hline 1994 & -. & i-- & $j_{89}$ \\
\hline
\end{tabular}


05483349 Middle Raccoon River tributary at Carroll, Iowa

Peak stages and discharges--Continued

\begin{tabular}{cccc}
\hline Water year & Date & $\begin{array}{c}\text { Gage height } \\
(\mathrm{ft})\end{array}$ & $\begin{array}{c}\text { Discharge } \\
\left(\mathrm{ft}^{3} / \mathbf{s}\right)\end{array}$ \\
\hline 1995 & Mar. 14, 1995 & 21.45 & -- \\
1996 & July 17,1996 & 25.88 & $\mathrm{n}_{4,600}$ \\
\hline
\end{tabular}

${ }^{a}$ Affected by ice.

${ }^{\mathrm{b}}$ Approximate.

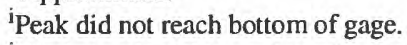

${ }^{\mathrm{j}}$ Discharge less than indicated value.

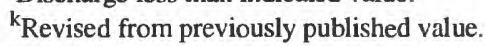

"Discharge computed from indirect measurement. 


\section{Middle Raccoon River near Bayard, Iowa}

Location.--Lat $41^{\circ} 46^{\prime} 43^{\prime \prime}$, long 94'29'33", in SW1/4 SW1/4 sec. 32, T.81 N., R. 31 W., Guthrie County, Hydrologic Unit 07100007, on left bank $15 \mathrm{ft}$ downstream from bridge on State Highway 25, $0.2 \mathrm{mi}$ downstream from Battle Run Creek, $1.8 \mathrm{mi}$ upstream from Springbrook Creek, $5.8 \mathrm{mi}$ southeast of Bayard, 10.3 mi upstream from dam at Lake Panorama, and at mile 78.0 upstream from mouth of Raccoon River.

Drainage area.--375 $\mathrm{mi}^{2}$.

Gage.--Water-stage recorder. Datum is $1,040.00 \mathrm{ft}$ above sea level. Prior to June 23, 1979, nonrecording gage, at present site and datum.

Stage-discharge relation.--Defined by current-meter measurements.

Bankfull stage.--About $14 \mathrm{ft}$.

Remarks.--Base for partial-duration series, $1,200 \mathrm{ft}^{3} / \mathrm{s}$.

Peak stages and discharges

[Water year, October 1-September 30; ft, feet above gage datum; $\mathrm{ft}^{3} / \mathrm{s}$, cubic feet per second; --, not determined]

\begin{tabular}{|c|c|c|c|}
\hline Water year & Date & $\begin{array}{l}\text { Gage height } \\
\text { (ft) }\end{array}$ & $\begin{array}{c}\text { Discharge } \\
\left(\mathrm{ft}^{3} / \mathrm{s}\right)\end{array}$ \\
\hline 1973 & July 3,1973 & $c_{21.63}$ & ${ }^{\mathrm{n}} 14,600$ \\
\hline \multirow[t]{2}{*}{1979} & Mar. 19,1979 & $c_{20.81}$ & 9,250 \\
\hline & (Systematic operati & in March 23, 1 & \\
\hline \multirow[t]{7}{*}{$\mathbf{p}_{1979}$} & Mar. 23, 1979 & 17.68 & 3,460 \\
\hline & Mar. 30,1979 & 14.74 & 2,520 \\
\hline & May 3,1979 & 12.73 & 1,220 \\
\hline & June 28,1979 & 17.65 & 3,410 \\
\hline & July 23,1979 & 16.63 & 2,770 \\
\hline & July 24,1979 & 13.36 & 1,440 \\
\hline & July 30,1979 & 12.79 & 1,240 \\
\hline 1980 & Mar. 16,1980 & 11.51 & 859 \\
\hline \multirow[t]{4}{*}{1981} & May 23,1981 & 13.73 & 1,580 \\
\hline & June 30,1981 & 15.74 & 2,370 \\
\hline & July $\quad 4,1981$ & 13.23 & 1,400 \\
\hline & Aug. 2,1981 & 15.34 & 2,200 \\
\hline \multirow[t]{7}{*}{1982} & Feb. 22,1982 & ${ }^{\mathrm{a}} 18.71$ & $b_{3,480}$ \\
\hline & Mar. 12,1982 & 13.21 & 1,390 \\
\hline & Mar. 20, 1982 & 17.53 & 3,340 \\
\hline & May 20,1982 & 15.16 & 2,130 \\
\hline & May 22,1982 & 13.20 & 1,390 \\
\hline & May 27,1982 & 17.00 & 2,970 \\
\hline & June 16,1982 & 16.14 & 2,540 \\
\hline \multirow[t]{5}{*}{1983} & Feb. 20,1983 & 17.30 & 3,180 \\
\hline & Mar. 7, 1983 & 15.79 & 2,390 \\
\hline & Apr. $\quad 1,1983$ & 15.62 & 2,320 \\
\hline & Apr. 13,1983 & 14.25 & 1,770 \\
\hline & May 3,1983 & 15.44 & 2,140 \\
\hline
\end{tabular}




\section{Middle Raccoon River near Bayard, Iowa}

Peak stages and discharges--Continued

\begin{tabular}{|c|c|c|c|}
\hline Water year & Date & $\begin{array}{l}\text { Gage height } \\
\text { (ft) }\end{array}$ & $\begin{array}{c}\text { Discharge } \\
\left(\mathrm{ft}^{3} / \mathrm{s}\right)\end{array}$ \\
\hline \multirow[t]{2}{*}{ 1983--Continued } & June 30,1983 & 18.03 & 3,310 \\
\hline & July 2,1983 & 19.79 & 5,190 \\
\hline \multirow[t]{11}{*}{1984} & Feb. 16,1984 & 14.76 & 1,700 \\
\hline & Apr. 9,1984 & 14.24 & 1,440 \\
\hline & Apr. 22,1984 & 16.12 & 2,150 \\
\hline & Apr. 27,1984 & 15.72 & 2,000 \\
\hline & Apr. 30,1984 & 19.99 & 4,960 \\
\hline & May 25,1984 & 14.02 & 1,420 \\
\hline & May 29,1984 & 15.65 & 2,060 \\
\hline & June 13,1984 & 15.14 & 1,920 \\
\hline & June 15,1984 & 16.33 & 2,400 \\
\hline & June 17,1984 & 18.50 & 3,700 \\
\hline & June 20,1984 & 14.85 & 1,810 \\
\hline 1985 & Feb. 22,1985 & ${ }^{a} 14.10$ & 1,170 \\
\hline \multirow[t]{11}{*}{1986} & Feb. 27,1986 & a.. & 1,500 \\
\hline & Mar. 16, 1986 & 13.08 & 1,210 \\
\hline & Mar. 19, 1986 & 18.49 & 3,630 \\
\hline & May 11,1986 & 19.25 & 4,400 \\
\hline & May 17,1986 & 14.88 & 1,600 \\
\hline & June 14,1986 & 15.64 & 1,800 \\
\hline & June 30,1986 & 24.70 & 12,300 \\
\hline & July 6,1986 & 16.43 & 2,060 \\
\hline & July 12,1986 & 14.20 & 1,290 \\
\hline & Aug. 5,1986 & 16.22 & 2,010 \\
\hline & Aug. 14,1986 & 20.24 & 5,200 \\
\hline \multirow[t]{5}{*}{1987} & Oct. 12,1986 & 18.24 & 3,350 \\
\hline & July 12,1987 & 16.12 & 1,970 \\
\hline & Aug. 13, 1987 & 14.11 & 1,310 \\
\hline & Aug. 26, 1987 & 16.54 & 2,180 \\
\hline & Sept. 17,1987 & 14.35 & 1,330 \\
\hline \multirow[t]{2}{*}{1988} & June 8,1988 & 16.63 & 2,230 \\
\hline & July 18,1988 & 14.52 & 1,390 \\
\hline \multirow[t]{4}{*}{1989} & Mar. 10, 1989 & ${ }^{\mathrm{a}} 18.35$ & 1,450 \\
\hline & May 24,1989 & 17.35 & 2,620 \\
\hline & May 29, 1989 & 14.68 & 1,440 \\
\hline & Sept. 8,1989 & 18.11 & 3,090 \\
\hline \multirow[t]{6}{*}{1990} & May 20,1990 & 20.20 & 5,180 \\
\hline & May 25,1990 & 18.35 & 3,290 \\
\hline & June 14,1990 & 19.19 & 4,080 \\
\hline & June 17,1990 & 23.23 & 9,570 \\
\hline & June 23,1990 & 17.02 & 2,370 \\
\hline & June 28,1990 & 17.65 & 2,750 \\
\hline
\end{tabular}


05483450 Middle Raccoon River near Bayard, Iowa

Peak stages and discharges--Continued

\begin{tabular}{|c|c|c|c|}
\hline Water year & Date & $\begin{array}{c}\text { Gage height } \\
\text { (ft) }\end{array}$ & $\begin{array}{c}\text { Discharge } \\
\left(\mathrm{ft}^{3} / \mathrm{s}\right)\end{array}$ \\
\hline \multirow[t]{3}{*}{ 1990--Continued } & July 11,1990 & 16.21 & 1,910 \\
\hline & July 26,1990 & 15.95 & 1,800 \\
\hline & Aug. 25,1990 & 16.41 & 2,070 \\
\hline \multirow[t]{6}{*}{1991} & Mar. 23, 1991 & 14.83 & 1,510 \\
\hline & Apr. 14,1991 & 18.97 & 3,870 \\
\hline & Apr. 19,1991 & 15.51 & 1,730 \\
\hline & Apr. 27,1991 & 16.48 & 2,170 \\
\hline & May 6,1991 & 14.66 & 1,460 \\
\hline & June 16,1991 & 19.28 & 4,170 \\
\hline \multirow[t]{2}{*}{1992} & Apr. 21,1992 & 13.96 & 1,220 \\
\hline & July 25,1992 & 16.10 & 1,940 \\
\hline \multirow[t]{17}{*}{1993} & Mar. 9,1993 & ${ }^{a} 18.95$ & 3,500 \\
\hline & Mar. 17, 1993 & 16.44 & 2,320 \\
\hline & Mar. 24, 1993 & 14.56 & 1,520 \\
\hline & Mar. 27, 1993 & 14.20 & 1,370 \\
\hline & Apr. 20,1993 & 14.05 & 1,290 \\
\hline & May 12,1993 & 17.76 & 2,940 \\
\hline & June 14,1993 & 15.33 & 1,760 \\
\hline & June 17,1993 & 17.99 & 3,070 \\
\hline & June 19,1993 & 15.55 & 1,850 \\
\hline & June 30,1993 & 15.57 & 1,860 \\
\hline & July 9,1993 & 29.02 & 27,500 \\
\hline & July 18,1993 & 15.56 & 1,940 \\
\hline & July 22,1993 & 13.95 & 1,300 \\
\hline & July 25,1993 & 13.83 & 1,260 \\
\hline & Aug. 11,1993 & 17.57 & 2,930 \\
\hline & Aug. 19, 1993 & 15.46 & 1,910 \\
\hline & Aug. 31,1993 & 18.20 & 3,330 \\
\hline 1994 & Feb. 19,1994 & ${ }^{\mathrm{a}} 19.94$ & 2,000 \\
\hline \multirow[t]{3}{*}{1995} & Mar. 12,1995 & 14.24 & 1,450 \\
\hline & May 10,1995 & 14.42 & 1,510 \\
\hline & May 28,1995 & 18.18 & 3,320 \\
\hline \multirow[t]{6}{*}{1996} & May 28,1996 & 14.70 & 1,540 \\
\hline & June 22,1996 & 20.77 & 5,290 \\
\hline & June 25,1996 & 13.89 & 1,280 \\
\hline & July 18,1996 & 20.83 & 5,370 \\
\hline & July 28,1996 & 14.22 & 1,390 \\
\hline & Aug. 6,1996 & 20.63 & 5,110 \\
\hline
\end{tabular}

${ }^{\mathrm{a} A f f e c t e d ~ b y ~ i c e . ~}$

${ }^{b}$ Approximate.

${ }^{\mathrm{C}} \mathrm{Gage}$ height determined from floodmark.

${ }^{\mathrm{n}}$ Discharge computed from indirect measurement.

PPeaks for 1979 are from March 23 to September 30. 


\section{Middle Raccoon River at Panora, Iowa}

Location.--Lat $41^{\circ} 41^{\prime} 14^{\prime \prime}$, long 94²2'15", in NE1/4 NW1/4 sec. 5, T.79 N., R.30 W., Guthrie County, Hydrologic Unit 07100007 , on left bank $15 \mathrm{ft}$ downstream from bridge on Soldier Trail, 0.2 mi southwest of Panora, 1.5 mi upstream from Andy's Branch, 1.6 mi downstream from Lake Panorama, 18.1 mi upstream from mouth, and at mile 66.1 upstream from mouth of Raccoon River.

Drainage area.--440 $\mathrm{mi}^{2}$.

Gage.--Water-stage recorder and concrete control. Datum is $991.20 \mathrm{ft}$ above sea level.

Stage-discharge relation.--Defined by current-meter and indirect measurements, and by theoretical rating-curve extension techniques.

Remarks.--Base for partial-duration series, $2,500 \mathrm{ft}^{3} / \mathrm{s}$. City of Panora diverts approximately 100 acre-ft/yr upstream of station. Flow regulated by dam on Lake Panorama since August 1970.

\section{Peak stages and discharges}

[Water year, October 1-September 30; $\mathrm{ft}$, feet above gage datum; $\mathrm{ft}^{3} / \mathrm{s}$, cubic feet per second; --, not determined]

\begin{tabular}{|c|c|c|c|}
\hline Water year & Date & $\begin{array}{l}\text { Gage height } \\
\text { (ft) }\end{array}$ & $\begin{array}{c}\text { Discharge } \\
\left(\mathrm{ft}^{3} / \mathrm{s}\right)\end{array}$ \\
\hline \multirow[t]{2}{*}{1953} & June 10,1953 & ${ }^{\mathrm{c}} 14.3$ & ${ }^{b} 14,000$ \\
\hline & \multicolumn{3}{|c|}{ (Systematic operation of gage began June 24,1958 .) } \\
\hline \multirow[t]{3}{*}{$\mathrm{q}_{1958}$} & July 2,1958 & 11.87 & 9,150 \\
\hline & July 3,1958 & 8.95 & 4,200 \\
\hline & July 19,1958 & 8.07 & 3,020 \\
\hline 1959 & June 1,1959 & 7.50 & 2,480 \\
\hline \multirow[t]{2}{*}{1960} & Mar. 31,1960 & 9.68 & 5,320 \\
\hline & May 7,1960 & 8.33 & 3,740 \\
\hline 1961 & June 16,1961 & 7.82 & 2,730 \\
\hline \multirow[t]{2}{*}{1962} & Mar. 26, 1962 & 9.29 & 4,620 \\
\hline & June 10,1962 & 8.85 & 3,940 \\
\hline 1963 & Aug. 7,1963 & 9.05 & 4,200 \\
\hline 1964 & June 22,1964 & 10.47 & 6,300 \\
\hline \multirow[t]{5}{*}{1965} & Mar. 2, 1965 & ${ }^{\mathrm{a}} 11.54$ & $b_{4,600}$ \\
\hline & Mar. 17,1965 & 10.87 & 6,890 \\
\hline & Apr. 2,1965 & 8.49 & 3,540 \\
\hline & Apr. $\quad 5,1965$ & 9.35 & 4,690 \\
\hline & May 27,1965 & 7.90 & 2,840 \\
\hline \multirow[t]{2}{*}{1966} & June 12,1966 & 8.54 & 3,480 \\
\hline & June 29,1966 & 8.79 & 3,800 \\
\hline \multirow[t]{4}{*}{1967} & June 7,1967 & 8.45 & 3,550 \\
\hline & June 10,1967 & ${ }^{c} 9.95$ & 5,600 \\
\hline & June 12,1967 & 8.37 & 3,450 \\
\hline & June 25,1967 & ${ }^{c} 9.53$ & 5,010 \\
\hline 1968 & June 26,1968 & 6.18 & 1,150 \\
\hline \multirow[t]{3}{*}{1969} & Mar. 20, 1969 & ${ }^{c} 9.84$ & 5,380 \\
\hline & Mar. 24, 1969 & 10.25 & 5,950 \\
\hline & July 10,1969 & 7.93 & 2,870 \\
\hline
\end{tabular}




\section{Middle Raccoon River at Panora, Iowa}

Peak stages and discharges--Continued

\begin{tabular}{|c|c|c|c|}
\hline Water year & Date & $\begin{array}{c}\text { Gage height } \\
\text { (ft) }\end{array}$ & $\begin{array}{c}\text { Discharge } \\
\left(\mathrm{ft}^{3} / \mathrm{s}\right)\end{array}$ \\
\hline 1970 & May 15,1970 & 7.83 & 2,780 \\
\hline \multicolumn{4}{|c|}{ (Flow regulation by operation of Lake Panorama Dam began in August 1970.) } \\
\hline 1971 & Feb. 19,1971 & ${ }^{\mathrm{a}} 12.98$ & $\mathrm{~b}_{8,900}$ \\
\hline \multirow[t]{4}{*}{1972} & Mar. 1,1972 & 7.63 & 2,670 \\
\hline & May 7,1972 & 7.51 & 2,550 \\
\hline & June 17,1972 & 8.17 & 3,300 \\
\hline & Aug. 2,1972 & 9.64 & 5,110 \\
\hline \multirow[t]{8}{*}{1973} & Mar. 2,1973 & 7.87 & 2,970 \\
\hline & Apr. 16,1973 & 8.35 & 3,370 \\
\hline & Apr. 26,1973 & 8.39 & 3,380 \\
\hline & May 9,1973 & 8.87 & 4,180 \\
\hline & June 4,1973 & 8.04 & 3,190 \\
\hline & July $\quad 3,1973$ & 13.56 & 12,000 \\
\hline & July 30,1973 & 9.39 & 4,570 \\
\hline & Sept. 28,1973 & 8.99 & 4,090 \\
\hline \multirow[t]{5}{*}{1974} & May 17,1974 & 7.85 & 2,810 \\
\hline & May 19,1974 & 14.80 & 14,000 \\
\hline & May 21,1974 & 9.00 & 4,240 \\
\hline & May 27,1974 & 9.13 & 4,410 \\
\hline & June 14,1974 & 8.13 & 3,150 \\
\hline \multirow[t]{3}{*}{1975} & Apr. 29,1975 & 8.36 & 3,420 \\
\hline & June 18,1975 & 7.88 & 2,850 \\
\hline & Aug. 27,1975 & 7.90 & 2,870 \\
\hline 1976 & May 23,1976 & 11.05 & 7,300 \\
\hline 1977 & Aug. 26, 1977 & 7.75 & 2,690 \\
\hline \multirow[t]{2}{*}{1978} & Mar. 20, 1978 & 8.97 & 4,180 \\
\hline & Sept. 13,1978 & 9.18 & 4,470 \\
\hline \multirow[t]{5}{*}{1979} & Mar. 19, 1979 & 12.95 & 10,700 \\
\hline & Mar. 24, 1979 & 7.78 & 2,730 \\
\hline & Mar. 30,1979 & 7.58 & 2,500 \\
\hline & June 28,1979 & 8.53 & 3,630 \\
\hline & July 23,1979 & 7.66 & 2,590 \\
\hline 1980 & June 4,1980 & 8.30 & 3,350 \\
\hline 1981 & Aug. 14,1981 & 7.46 & 2,380 \\
\hline \multirow[t]{4}{*}{1982} & Feb. 23,1982 & 9.13 & 4,330 \\
\hline & Mar. 19, 1982 & 8.21 & 3,210 \\
\hline & May 27,1982 & 8.42 & 3,580 \\
\hline & June 16,1982 & 8.26 & 3,350 \\
\hline \multirow[t]{3}{*}{1983} & Feb. 16,1983 & 7.69 & 2,620 \\
\hline & Feb. 20,1983 & 7.94 & 2,920 \\
\hline & Mar. 7,1983 & 7.82 & 2,770 \\
\hline
\end{tabular}




\section{Middle Raccoon River at Panora, Iowa}

Peak stages and discharges--Continued

\begin{tabular}{|c|c|c|c|}
\hline Water year & Date & $\begin{array}{l}\text { Gage height } \\
\text { (ft) }\end{array}$ & $\begin{array}{c}\text { Discharge } \\
\left(\mathrm{ft}^{3} / \mathrm{s}\right)\end{array}$ \\
\hline \multirow[t]{3}{*}{ 1983--Continued } & Apr. 1,1983 & 8.29 & 3,340 \\
\hline & June 28,1983 & 8.61 & 3,730 \\
\hline & July 2,1983 & 9.81 & 5,360 \\
\hline \multirow[t]{6}{*}{1984} & Feb. 16,1984 & 7.78 & 2,730 \\
\hline & Apr. 4,1984 & 7.73 & 2,680 \\
\hline & Apr. 23,1984 & 7.85 & 2,810 \\
\hline & Apr. 30,1984 & 11.18 & 7,530 \\
\hline & June 16,1984 & 8.19 & 3,210 \\
\hline & June 17,1984 & 8.89 & 4,090 \\
\hline 1985 & Dec. 29,1984 & 7.43 & 2,350 \\
\hline \multirow[t]{7}{*}{1986} & Feb. 28,1986 & 8.18 & 3,200 \\
\hline & Mar. 19,1986 & 8.09 & 3,090 \\
\hline & May 11,1986 & 9.08 & 4,330 \\
\hline & May 25,1986 & 8.13 & 3,140 \\
\hline & June 30,1986 & 15.50 & 15,300 \\
\hline & Aug. 5, 1986 & 8.55 & 3,450 \\
\hline & Aug. 14,1986 & 9.88 & 4,970 \\
\hline \multirow[t]{2}{*}{1987} & Oct. 12,1986 & 8.42 & 3,320 \\
\hline & Aug. 26, 1987 & 8.07 & 2,960 \\
\hline 1988 & June 8,1988 & 7.40 & 2,300 \\
\hline 1989 & Sept. 8,1989 & 8.40 & 3,300 \\
\hline \multirow[t]{8}{*}{1990} & May 20,1990 & 9.27 & 4,520 \\
\hline & May 25,1990 & 8.29 & 3,530 \\
\hline & June 13,1990 & 8.66 & 3,900 \\
\hline & June 18,1990 & 12.77 & 9,000 \\
\hline & June 23,1990 & 8.00 & 3,190 \\
\hline & June 28,1990 & 7.72 & 2,880 \\
\hline & July 11,1990 & 7.38 & 2,520 \\
\hline & Aug. 26,1990 & 8.46 & 3,690 \\
\hline \multirow[t]{4}{*}{1991} & Apr. 15,1991 & 8.52 & 3,420 \\
\hline & Apr. 27,1991 & 8.21 & 3,100 \\
\hline & June 14,1991 & 8.83 & 3,750 \\
\hline & June 16,1991 & 8.74 & 3,660 \\
\hline 1992 & Sept. 15,1992 & 7.21 & 2,100 \\
\hline \multirow[t]{5}{*}{1993} & Mar. 8,1993 & 8.73 & 3,770 \\
\hline & May 12,1993 & 7.79 & 2,720 \\
\hline & June 30,1993 & 7.69 & 2,610 \\
\hline & July $\quad 9,1993$ & 20.04 & 22,400 \\
\hline & Aug. 30, 1993 & 8.01 & 2,960 \\
\hline 1994 & Feb. 18,1994 & ${ }^{2} 7.28$ & 1,300 \\
\hline \multirow[t]{2}{*}{1995} & May 28,1995 & 9.20 & 4,320 \\
\hline & Aug. 6,1995 & 10.49 & 5,920 \\
\hline
\end{tabular}




\section{Middle Raccoon River at Panora, Iowa}

Peak stages and discharges--Continued

\begin{tabular}{clcc}
\hline Water year & Date & $\begin{array}{c}\text { Gage height } \\
(\mathbf{f t})\end{array}$ & $\begin{array}{c}\text { Discharge } \\
\left(\mathrm{ft}^{3} / \mathbf{s}\right)\end{array}$ \\
\hline 1996 & May 9,1996 & 8.11 & 3,070 \\
& June 22, 1996 & 9.28 & 4,410 \\
& June 24, 1996 & 8.00 & 2,950 \\
& July 18, 1996 & 9.42 & 4,580 \\
& Aug. 6, 1996 & 9.26 & 4,390 \\
\hline
\end{tabular}

aAfected by ice.

${ }^{b}$ Approximate.

${ }^{\mathrm{c}} \mathrm{Gage}$ height determined from floodmark.

GPeaks for 1958 are from June 24 to September 30. 


\section{South Raccoon River at Redfield, Iowa}

Location.--Lat $41^{\circ} 35^{\prime} 22^{\prime \prime}$, long 9509'04", in SW1/4 NE1/4 sec. 2, T.78 N., R.29 W., Dallas County, Hydrologic Unit 07100007, on right bank $20 \mathrm{ft}$ upstream from bridge on $\mathrm{H}$ Avenue, $3.4 \mathrm{mi}$ downstream from bridge on U.S. Highway 6, 3.4 mi downstream from mouth of confluence with Middle Raccoon River, 14.3 mi upstream from mouth, and at mile 44.6 upstream from mouth of Raccoon River.

Drainage area.--994 $\mathrm{mi}^{2}$.

Gage.--Water-stage recorder. Datum is $888.88 \mathrm{ft}$ above sea level. Prior to June 12, 1946, nonrecording gage, and June 12,1946 , to Sept. 30, 1986, water-stage recorder at site 2.4 mi upstream, at datum $7.55 \mathrm{ft}$ higher.

Stage-discharge relation.--Defined by current-meter measurements.

Flood stage.--14 ft.

Remarks.--Base for partial-duration series, $5,000 \mathrm{ft}^{3} / \mathrm{s}$.

Peak stages and discharges

[Water year, October 1-September 30; ft, feet above gage datum; $\mathrm{ft}^{3} / \mathrm{s}$, cubic feet per second; --, not determined]

\begin{tabular}{|c|c|c|c|}
\hline Water year & Date & $\begin{array}{l}\text { Gage height } \\
\text { (ft) }\end{array}$ & $\begin{array}{c}\text { Discharge } \\
\left(\mathrm{ft}^{3} / \mathrm{s}\right)\end{array}$ \\
\hline \multicolumn{4}{|c|}{ (Systematic operation of gage began in March 1940.) } \\
\hline${ }^{r} 1940$ & July 31,1940 & 13.3 & 6,100 \\
\hline 1941 & June 28,1941 & 10.5 & 3,550 \\
\hline \multirow[t]{2}{*}{1942} & May 11,1942 & 13.0 & 5,740 \\
\hline & Aug. 28,1942 & 13.4 & 6,380 \\
\hline 1943 & Aug. 25,1943 & 14.1 & 6,610 \\
\hline \multirow[t]{4}{*}{1944} & May 3,1944 & 13.2 & 5,930 \\
\hline & May 20,1944 & 23.8 & 20,000 \\
\hline & May 23, 1944 & 16.9 & 9,750 \\
\hline & June 11,1944 & 13.7 & 6,430 \\
\hline \multirow[t]{4}{*}{1945} & May 14,1945 & 15.0 & 7,730 \\
\hline & May 22,1945 & 17.2 & 10,100 \\
\hline & May 30,1945 & 15.0 & 7,730 \\
\hline & June 6,1945 & 13.1 & 5,830 \\
\hline \multirow[t]{2}{*}{1946} & Aug. 24, 1946 & 18.9 & 12,000 \\
\hline & Sept. 8,1946 & 21.4 & 15,200 \\
\hline \multirow[t]{4}{*}{1947} & June 2,1947 & 19.9 & 15,000 \\
\hline & June 5,1947 & 22.7 & 20,500 \\
\hline & June 12,1947 & 24.3 & 23,800 \\
\hline & June 24,1947 & 16.7 & 10,500 \\
\hline 1948 & Mar. 19, 1948 & 21.3 & 17,600 \\
\hline 1949 & Mar. 6,1949 & 14.2 & 7,530 \\
\hline \multirow[t]{3}{*}{1950} & May 5,1950 & 14.7 & 7,990 \\
\hline & June 19,1950 & 17.9 & 11,600 \\
\hline & June 23,1950 & 13.8 & 7,080 \\
\hline
\end{tabular}




\section{South Raccoon River at Redfield, Iowa}

Peak stages and discharges--Continued

\begin{tabular}{|c|c|c|c|}
\hline Water year & Date & $\begin{array}{c}\text { Gage height } \\
\text { (ft) }\end{array}$ & $\begin{array}{c}\text { Discharge } \\
\left(\mathrm{ft}^{3} / \mathrm{s}\right)\end{array}$ \\
\hline \multirow[t]{5}{*}{1951} & Mar. 29,1951 & 20.10 & 15,400 \\
\hline & May 2,1951 & 17.70 & 11,700 \\
\hline & June 2,1951 & 18.14 & 12,200 \\
\hline & June 7,1951 & 12.19 & 5,680 \\
\hline & July 3,1951 & 16.26 & 10,100 \\
\hline \multirow[t]{4}{*}{1952} & Mar. 13, 1952 & 11.53 & 5,160 \\
\hline & Mar. 31, 1952 & 14.39 & 7,840 \\
\hline & June 21,1952 & 12.12 & 5,680 \\
\hline & June 27,1952 & 16.06 & 9,740 \\
\hline \multirow[t]{2}{*}{1953} & May 24,1953 & 12.23 & 5,680 \\
\hline & June 10,1953 & 23.08 & 21,300 \\
\hline 1954 & Aug. 22, 1954 & 13.84 & 7,200 \\
\hline 1955 & Apr. 24,1955 & 12.86 & 6,310 \\
\hline 1956 & Sept. 4,1956 & 9.80 & 3,840 \\
\hline 1957 & June 17,1957 & 17.80 & 12,700 \\
\hline \multirow[t]{4}{*}{1958} & July $\quad 2,1958$ & $c_{29.04}$ & 35,000 \\
\hline & July $\quad 4,1958$ & 19.28 & 14,200 \\
\hline & July 19,1958 & 15.80 & 9,580 \\
\hline & Sept. $\quad 6,1958$ & 25.12 & 25,500 \\
\hline 1959 & May 30,1959 & 10.95 & 5,420 \\
\hline \multirow[t]{2}{*}{1960} & Mar. 30,1960 & 15.29 & 9,340 \\
\hline & May 7,1960 & 15.31 & 9,340 \\
\hline \multirow[t]{4}{*}{1961} & Feb. 23,1961 & 11.23 & 5,590 \\
\hline & Mar. 27, 1961 & 10.67 & 5,160 \\
\hline & June 14,1961 & 10.78 & 5,250 \\
\hline & Sept. 30,1961 & 11.00 & 5,420 \\
\hline \multirow[t]{4}{*}{1962} & Mar. 19,1962 & ${ }^{a, c} \mathbf{c} 17.50$ & -- \\
\hline & Mar. 24, 1962 & 14.42 & 8,350 \\
\hline & May 29,1962 & 15.46 & 9,340 \\
\hline & June 9,1962 & 13.01 & 7,090 \\
\hline \multirow[t]{3}{*}{1963} & Mar. 3,1963 & ${ }^{\mathrm{a}} 13.43$ & $b_{6,300}$ \\
\hline & Apr. 29,1963 & 15.25 & 9,240 \\
\hline & Aug. 7,1963 & 10.85 & 5,080 \\
\hline \multirow[t]{2}{*}{1964} & Apr. 13,1964 & 13.57 & 7,720 \\
\hline & June 23,1964 & 19.69 & 14,900 \\
\hline \multirow[t]{5}{*}{1965} & Feb. 21,1965 & ${ }^{\mathrm{a}} 11.82$ & $\mathrm{~b}_{5,600}$ \\
\hline & Mar. 2, 1965 & 17.70 & 12,800 \\
\hline & Mar. 17,1965 & 19.60 & 15,800 \\
\hline & Apr. $\quad 1,1965$ & 15.14 & 9,350 \\
\hline & Apr. 5,1965 & 16.99 & 11,800 \\
\hline 1966 & June 12,1966 & 15.17 & 9,460 \\
\hline \multirow[t]{3}{*}{1967} & June 8,1967 & 14.06 & 8,080 \\
\hline & June 10,1967 & 17.12 & 12,000 \\
\hline & June 12,1967 & 15.21 & 9,430 \\
\hline
\end{tabular}


05484000 South Raccoon River at Redfield, Iowa

Peak stages and discharges--Continued

\begin{tabular}{|c|c|c|c|}
\hline Water year & Date & $\begin{array}{c}\text { Gage height } \\
\text { (ft) }\end{array}$ & $\begin{array}{c}\text { Discharge } \\
\left(\mathrm{ft}^{3} / \mathrm{s}\right)\end{array}$ \\
\hline 1968 & Sept. 4,1968 & 6.27 & 1,710 \\
\hline \multirow[t]{4}{*}{1969} & Mar. 19, 1969 & 16.69 & 11,700 \\
\hline & Mar. 24, 1969 & 16.08 & 10,900 \\
\hline & June 29,1969 & 11.75 & 5,990 \\
\hline & July $\quad 9,1969$ & 13.55 & 7,780 \\
\hline 1970 & May 14,1970 & 14.50 & 9,050 \\
\hline \multirow[t]{3}{*}{1971} & Feb. 19,1971 & 20.82 & 17,800 \\
\hline & Mar. 14, 1971 & 14.61 & 9,200 \\
\hline & June $\quad 6,1971$ & 17.25 & 12,500 \\
\hline \multirow[t]{2}{*}{1972} & Aug. $\quad 2,1972$ & 12.82 & 7,220 \\
\hline & Sept. 11,1972 & 13.95 & 8,410 \\
\hline \multirow[t]{8}{*}{1973} & Mar. 14,1973 & 10.33 & 5,010 \\
\hline & Apr. $\quad 1,1973$ & 10.95 & 5,650 \\
\hline & Apr. 16,1973 & 14.77 & 9,650 \\
\hline & May 8,1973 & 17.63 & 13,000 \\
\hline & June 5,1973 & 10.74 & 5,260 \\
\hline & July $\quad 4,1973$ & 19.97 & 16,500 \\
\hline & July 30,1973 & 10.96 & 5,450 \\
\hline & Sept. 26,1973 & 14.74 & 9,310 \\
\hline \multirow[t]{7}{*}{1974} & Oct. 11,1973 & 11.96 & 6,380 \\
\hline & Apr. 21,1974 & 15.58 & 10,300 \\
\hline & Apr. 28,1974 & 12.93 & 7,380 \\
\hline & May 16,1974 & 10.64 & 5,210 \\
\hline & May 19,1974 & 21.85 & 20,000 \\
\hline & May 21,1974 & 13.42 & 8,300 \\
\hline & May 26,1974 & 11.52 & 6,150 \\
\hline \multirow[t]{3}{*}{1975} & Apr. 28,1975 & 15.45 & 10,200 \\
\hline & June 18,1975 & 14.28 & 8,680 \\
\hline & June 25,1975 & 12.40 & 6,720 \\
\hline \multirow[t]{2}{*}{1976} & Mar. 12, 1976 & 10.41 & 5,130 \\
\hline & May 23,1976 & 12.71 & 7,490 \\
\hline \multirow[t]{3}{*}{1977} & Aug. 26,1977 & 15.90 & 11,300 \\
\hline & Aug. 28, 1977 & 13.76 & 8,740 \\
\hline & Sept. 3,1977 & 12.97 & 7,870 \\
\hline \multirow[t]{5}{*}{1978} & Mar. 21,1978 & $a_{-}$ & 8,640 \\
\hline & Mar. 22, 1978 & 14.02 & 8,990 \\
\hline & Apr. 17,1978 & 17.13 & 12,700 \\
\hline & Sept. 13,1978 & 13.79 & 8,770 \\
\hline & Sept. 14,1978 & 14.63 & 9,760 \\
\hline \multirow[t]{3}{*}{1979} & Mar. 13, 1979 & 10.75 & 5,550 \\
\hline & Mar. 19,1979 & 22.81 & 20,400 \\
\hline & Aug. 10, 1979 & 12.10 & 6,910 \\
\hline 1980 & June 15,1980 & 7.47 & 2,700 \\
\hline 1981 & May 23,1981 & 7.08 & 2,430 \\
\hline
\end{tabular}




\section{South Raccoon River at Redfield, Iowa}

Peak stages and discharges--Continued

\begin{tabular}{|c|c|c|c|}
\hline Water year & Date & $\begin{array}{c}\text { Gage height } \\
\text { (ft) }\end{array}$ & $\begin{array}{c}\text { Discharge } \\
\left(\mathrm{ft}^{3} / \mathrm{s}\right)\end{array}$ \\
\hline \multirow[t]{5}{*}{1982} & Feb. 21,1982 & ${ }^{\mathrm{a}} 14.22$ & ${ }^{b} 6,150$ \\
\hline & Feb. 23,1982 & 12.46 & 5,650 \\
\hline & Mar. 19,1982 & 12.85 & 7,740 \\
\hline & May 28,1982 & 11.31 & 6,110 \\
\hline & June 15,1982 & 12.82 & 7,700 \\
\hline \multirow[t]{6}{*}{1983} & Dec. 28,1982 & 11.34 & 6,130 \\
\hline & Feb. 20,1983 & 12.92 & 7,800 \\
\hline & Mar. 31,1983 & 10.96 & 5,740 \\
\hline & May 19,1983 & 12.44 & 7,280 \\
\hline & June 29,1983 & 13.02 & 7,910 \\
\hline & July 3,1983 & 11.24 & 6,020 \\
\hline \multirow[t]{5}{*}{1984} & Apr. 30,1984 & 18.58 & 14,500 \\
\hline & May 25,1984 & 10.22 & 5,020 \\
\hline & June 15,1984 & 10.84 & 5,630 \\
\hline & June 16,1984 & 12.02 & 6,840 \\
\hline & June 17,1984 & 12.03 & 6,850 \\
\hline 1985 & Feb. 21,1985 & ${ }^{\mathrm{a}} 16.37$ & 6,200 \\
\hline \multirow[t]{11}{*}{1986} & Feb. 26,1986 & $a_{--}$ & 5,800 \\
\hline & Mar. 18,1986 & 9.67 & 5,030 \\
\hline & Apr. 30,1986 & 10.17 & 5,640 \\
\hline & May 11,1986 & 15.29 & 11,400 \\
\hline & May 16,1986 & 11.99 & 7,080 \\
\hline & July 1,1986 & 25.15 & 26,300 \\
\hline & July 10,1986 & 10.47 & 5,100 \\
\hline & July 14,1986 & 10.51 & 5,140 \\
\hline & Aug. 6,1986 & 10.46 & 5,070 \\
\hline & Aug. 14,1986 & 17.54 & 13,000 \\
\hline & \multicolumn{3}{|c|}{ (Gage moved to new site and datum October $1,1986$. ) } \\
\hline \multirow[t]{3}{*}{1987} & July 12,1987 & 11.44 & 7,290 \\
\hline & Aug. 26,1987 & 14.30 & 10,900 \\
\hline & Sept. 16,1987 & 11.10 & 6,340 \\
\hline 1988 & Jan. 30,1988 & ${ }^{a} 14.31$ & 8,400 \\
\hline 1989 & Sept. 8,1989 & 13.33 & 9,380 \\
\hline \multirow[t]{5}{*}{1990} & May 19,1990 & 10.92 & 6,890 \\
\hline & May 25,1990 & 10.73 & 6,660 \\
\hline & June 14,1990 & 10.32 & 6,190 \\
\hline & June 16,1990 & 19.05 & 19,100 \\
\hline & June 23,1990 & 9.69 & 5,240 \\
\hline \multirow[t]{6}{*}{1991} & Apr. 14,1991 & 14.70 & 11,500 \\
\hline & Apr. 18,1991 & 11.88 & 7,350 \\
\hline & Apr. 27,1991 & 12.80 & 8,610 \\
\hline & May 6,1991 & 11.44 & 6,280 \\
\hline & June 14,1991 & 16.20 & 12,000 \\
\hline & June 15,1991 & 13.84 & 8,470 \\
\hline
\end{tabular}




\section{South Raccoon River at Redfield, Iowa}

Peak stages and discharges--Continued

\begin{tabular}{|c|c|c|c|}
\hline Water year & Date & $\begin{array}{l}\text { Gage height } \\
\text { (ft) }\end{array}$ & $\begin{array}{c}\text { Discharge } \\
\left(\mathrm{ft}^{3} / \mathrm{s}\right)\end{array}$ \\
\hline 1992 & Sept. 16,1992 & 15.86 & 13,300 \\
\hline \multirow[t]{11}{*}{1993} & Mar. 8,1993 & 13.00 & 8,800 \\
\hline & June 18,1993 & 11.42 & 6,660 \\
\hline & July 1,1993 & 12.04 & 7,470 \\
\hline & July $\quad 8,1993$ & 14.48 & 11,000 \\
\hline & July 10,1993 & 26.98 & 44,000 \\
\hline & July 13,1993 & 16.82 & 15,000 \\
\hline & July 23,1993 & 10.12 & 5,110 \\
\hline & July 25,1993 & 10.82 & 5,920 \\
\hline & Aug. 12, 1993 & 16.52 & 14,500 \\
\hline & Aug. 19, 1993 & 11.55 & 6,830 \\
\hline & Aug. 29, 1993 & 20.46 & 22,400 \\
\hline 1994 & Mar. 5, 1994 & a.79 & 2,400 \\
\hline 1995 & May 28,1995 & 14.05 & 10,400 \\
\hline \multirow[t]{7}{*}{1996} & Feb. $\quad 9,1996$ & ${ }^{\mathrm{a}} 13.22$ & -- \\
\hline & May 10,1996 & 13.07 & 8,900 \\
\hline & May 24, 1996 & 13.51 & 9,540 \\
\hline & June 21,1996 & 15.25 & 12,300 \\
\hline & June 23,1996 & 10.58 & 5,640 \\
\hline & July 18,1996 & 14.86 & 11,600 \\
\hline & Aug. 5, 1996 & 13.79 & 9,960 \\
\hline
\end{tabular}

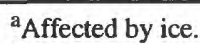

${ }^{\text {b Approximate. }}$

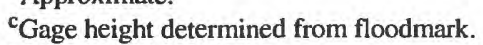

${ }^{\mathrm{T}}$ Peak for 1940 is from March to September 30. 


\section{Raccoon River at Van Meter, Iowa}

Location.--Lat $41^{\circ} 32^{\prime} 02^{\prime \prime}$, long 93'56'59", in SW1/4 SW1/4 sec. 22, T.78 N., R.27 W., Dallas County, Hydrologic Unit 07100006, on right bank $10 \mathrm{ft}$ downstream from bridge on County Road R16, $0.3 \mathrm{mi}$ northeast of Van Meter, 0.7 mi upstream from small left bank tributary, 1.1 mi downstream from confluence of North and South Raccoon Rivers, and 29.1 mi upstream from mouth.

Drainage area.--3,441 $\mathrm{mi}^{2}$.

Gage.--Water-stage recorder at present site since Aug. 9, 1934. Datum is $841.16 \mathrm{ft}$ above sea level. Prior to Oct. 1, 1915, chain gage at same site and at datum $2 \mathrm{ft}$ higher. Oct. 1, 1915, to May 30, 1923, chain gage; May 31, 1923, to Sept. 30, 1927, water-stage recorder; and Oct. 1, 1927, to Aug. 8, 1934, chain gage; all at same site and datum.

Stage-discharge relation.--Defined by current-meter measurements.

Flood stage.--13 ft.

Remarks.--Base for partial-duration series, $8,500 \mathrm{ft}^{3} / \mathrm{s}$.

Peak stages and discharges

[Water year, October 1-September 30; $\mathrm{ft}$, feet above gage datum; $\mathrm{ft}^{3} / \mathrm{s}$, cubic feet per second; --, not determined]

\begin{tabular}{|c|c|c|c|}
\hline Water year & Date & $\begin{array}{l}\text { Gage height } \\
\text { (ft) }\end{array}$ & $\begin{array}{c}\text { Discharge } \\
\left(\mathrm{ft}^{3} / \mathrm{s}\right)\end{array}$ \\
\hline \multicolumn{4}{|c|}{ (Systematic operation of gage began in April 1915.) } \\
\hline $\mathrm{s}_{1915}$ & May 29,1915 & 15.19 & 21,600 \\
\hline \multicolumn{4}{|c|}{ (New datum for gage October 1,1915 , at same site.) } \\
\hline 1916 & Mar. 16,1916 & 8.4 & 5,840 \\
\hline \multirow[t]{2}{*}{1917} & June 7,1917 & 18.4 & 35,200 \\
\hline & June 10,1917 & 17.0 & 26,000 \\
\hline 1918 & June 6,1918 & 13.7 & 14,800 \\
\hline \multirow[t]{4}{*}{1919} & Apr. 24,1919 & 12.6 & 12,400 \\
\hline & May 4,1919 & 12.4 & 12,000 \\
\hline & June 4,1919 & 11.7 & 10,700 \\
\hline & June 11,1919 & 11.8 & 11,000 \\
\hline 1920 & Mar. 14,1920 & ${ }^{\mathrm{a}} 12.2$ & ${ }^{b} 10,000$ \\
\hline 1921 & Sept. 20,1921 & 11.1 & 9,670 \\
\hline 1922 & Apr. 11,1922 & 12.1 & 11,400 \\
\hline 1923 & Mar. 27,1923 & 11.6 & 10,300 \\
\hline \multirow[t]{3}{*}{1924} & Oct. 3,1923 & 11.2 & 10,000 \\
\hline & June 8,1924 & 12.3 & 12,400 \\
\hline & June 25,1924 & 15.2 & 20,100 \\
\hline 1925 & Aug. 7,1925 & 10.1 & 8,060 \\
\hline 1926 & Sept. 20,1926 & 19.0 & 32,000 \\
\hline 1927 & Feb. $\quad 8,1927$ & 9.7 & 6,880 \\
\hline 1928 & Aug. 27,1928 & 10.8 & 8,480 \\
\hline 1929 & Mar. 14,1929 & 16.2 & 19,400 \\
\hline 1930 & May 13,1930 & 8.8 & 5,870 \\
\hline 1931 & June 21,1931 & 8.3 & 5,270 \\
\hline
\end{tabular}


05484500 Raccoon River at Van Meter, Iowa

Peak stages and discharges--Continued

\begin{tabular}{|c|c|c|c|}
\hline Water year & Date & $\begin{array}{l}\text { Gage height } \\
\text { (ft) }\end{array}$ & $\begin{array}{c}\text { Discharge } \\
\left(\mathrm{ft}^{3} / \mathrm{s}\right)\end{array}$ \\
\hline \multirow[t]{3}{*}{1932} & Nov. 24,1931 & 14.6 & 15,200 \\
\hline & Jan. $\quad 1,1932$ & 12.5 & 11,400 \\
\hline & Mar. 4,1932 & 14.2 & 14,200 \\
\hline 1933 & Apr. $\quad 5,1933$ & 10.1 & 7,550 \\
\hline 1934 & Apr. 7,1934 & 5.0 & 2,020 \\
\hline 1935 & Mar. 5,1935 & 13.1 & 11,000 \\
\hline 1936 & Mar. 5,1936 & 13.9 & 12,200 \\
\hline 1937 & Mar. 4,1937 & 13.9 & 12,200 \\
\hline 1938 & June $\quad 2,1938$ & 11.6 & 8,590 \\
\hline \multirow[t]{2}{*}{1939} & Mar. 12, 1939 & ${ }^{a} 17.85$ & ${ }^{b} 14,000$ \\
\hline & Mar. 16, 1939 & 13.0 & 10,600 \\
\hline 1940 & July 31,1940 & 9.2 & 5,770 \\
\hline 1941 & June 2,1941 & 10.0 & 6,920 \\
\hline 1942 & May 11,1942 & 11.7 & 8,800 \\
\hline \multirow[t]{2}{*}{1943} & June 16,1943 & 12.9 & 10,000 \\
\hline & Aug. 16, 1943 & 14.7 & 12,500 \\
\hline \multirow[t]{3}{*}{1944} & May 21,1944 & 18.3 & 23,400 \\
\hline & June 11,1944 & 15.1 & 13,100 \\
\hline & June 16,1944 & 17.2 & 17,900 \\
\hline \multirow[t]{7}{*}{1945} & Mar. 15,1945 & 13.7 & 11,600 \\
\hline & Apr. 28,1945 & 12.7 & 10,200 \\
\hline & May 15,1945 & 13.4 & 11,200 \\
\hline & May 23,1945 & 15.7 & 14,300 \\
\hline & May 31,1945 & 15.0 & 12,900 \\
\hline & June 6,1945 & 16.1 & 15,100 \\
\hline & June 13,1945 & 13.0 & 10,900 \\
\hline \multirow[t]{2}{*}{1946} & Aug. 25,1946 & 13.2 & 10,300 \\
\hline & Sept. 9,1946 & 16.1 & 15,100 \\
\hline \multirow[t]{5}{*}{1947} & June 3,1947 & 17.4 & 19,800 \\
\hline & June 5,1947 & 19.3 & 25,600 \\
\hline & June 13,1947 & ${ }^{c} 21.37$ & 41,200 \\
\hline & June 23,1947 & 16.4 & 17,300 \\
\hline & June 25,1947 & 21.1 & 38,000 \\
\hline 1948 & Mar. 19,1948 & 19.0 & 26,700 \\
\hline 1949 & Mar. 6,1949 & 15.7 & 15,900 \\
\hline \multirow[t]{3}{*}{1950} & Mar. 7,1950 & 12.4 & 11,300 \\
\hline & June 20,1950 & 16.1 & 17,600 \\
\hline & June 24,1950 & 14.0 & 13,700 \\
\hline \multirow[t]{6}{*}{1951} & Mar. 31,1951 & 19.15 & 27,700 \\
\hline & May 2,1951 & 17.00 & 19,900 \\
\hline & June 3,1951 & 17.13 & 20,200 \\
\hline & June 8,1951 & 14.47 & 14,400 \\
\hline & July $\quad 4,1951$ & 15.18 & 15,800 \\
\hline & July $\quad 6,1951$ & 11.55 & 10,100 \\
\hline
\end{tabular}




\section{Raccoon River at Van Meter, Iowa}

Peak stages and discharges--Continued

\begin{tabular}{|c|c|c|c|}
\hline Water year & Date & $\begin{array}{c}\text { Gage height } \\
\text { (ft) }\end{array}$ & $\begin{array}{c}\text { Discharge } \\
\left(\mathrm{ft}^{3} / \mathrm{s}\right)\end{array}$ \\
\hline \multirow[t]{2}{*}{1952} & Apr. $\quad 1,1952$ & 14.81 & 15,100 \\
\hline & June 27,1952 & 14.67 & 14,900 \\
\hline 1953 & June 11,1953 & 19.42 & 26,000 \\
\hline \multirow[t]{4}{*}{1954} & June 16,1954 & 12.46 & 11,000 \\
\hline & June 25,1954 & 17.40 & 20,800 \\
\hline & Aug. 22, 1954 & 12.07 & 10,200 \\
\hline & Aug. 31,1954 & 14.14 & 13,800 \\
\hline 1955 & Apr. 24,1955 & 11.43 & 8,620 \\
\hline 1956 & Sept. 4,1956 & 7.43 & 4,150 \\
\hline 1957 & June 18,1957 & 17.27 & 20,000 \\
\hline \multirow[t]{3}{*}{1958} & July $\quad 3,1958$ & 21.77 & 35,200 \\
\hline & July 20,1958 & 13.73 & 13,300 \\
\hline & Sept. 6,1958 & 17.76 & 20,900 \\
\hline 1959 & June 4,1959 & 13.22 & 13,500 \\
\hline \multirow[t]{3}{*}{1960} & Apr. 2,1960 & 21.18 & 32,300 \\
\hline & May 7,1960 & 14.62 & 14,800 \\
\hline & May 26,1960 & 11.76 & 10,400 \\
\hline 1961 & Mar. 27, 1961 & 12.35 & 11,300 \\
\hline \multirow[t]{4}{*}{1962} & Mar. 31,1962 & 17.23 & 19,700 \\
\hline & May 29,1962 & 14.33 & 14,900 \\
\hline & June 11,1962 & 12.42 & 11,900 \\
\hline & Sept. 7,1962 & 11.45 & 10,400 \\
\hline \multirow[t]{3}{*}{1963} & Mar. 4,1963 & $\mathrm{a}_{14.38}$ & $\mathrm{~b}_{10,000}$ \\
\hline & Mar. 11,1963 & 13.85 & 12,200 \\
\hline & Apr. 29,1963 & 12.62 & 12,200 \\
\hline 1964 & June 23,1964 & 15.92 & 17,400 \\
\hline \multirow[t]{5}{*}{1965} & Mar. 2,1965 & ${ }^{a} 14.73$ & $\mathrm{~b}_{13,000}$ \\
\hline & Mar. 17,1965 & ${ }^{a} 18.20$ & $\mathrm{~b}_{20,100}$ \\
\hline & Apr. 1,1965 & 13.93 & 14,300 \\
\hline & Apr. 6,1965 & 18.35 & 22,300 \\
\hline & May 30,1965 & 11.20 & 10,400 \\
\hline 1966 & June 13,1966 & 15.15 & 16,200 \\
\hline \multirow[t]{4}{*}{1967} & June 8,1967 & 13.09 & 12,300 \\
\hline & June 10,1967 & 17.04 & 18,700 \\
\hline & June 12,1967 & 18.07 & 20,600 \\
\hline & June 26,1967 & 12.11 & 10,900 \\
\hline 1968 & June 27,1968 & 7.05 & 4,360 \\
\hline \multirow[t]{5}{*}{1969} & Mar. 25, 1969 & 17.60 & 22,800 \\
\hline & Apr. $\quad 9,1969$ & 12.07 & 10,900 \\
\hline & June 29,1969 & 12.95 & 12,400 \\
\hline & July 10,1969 & 14.18 & 14,700 \\
\hline & July 18,1969 & 11.74 & 10,400 \\
\hline 1970 & May 14,1970 & 14.23 & 14,800 \\
\hline
\end{tabular}




\section{Raccoon River at Van Meter, Iowa}

Peak stages and discharges--Continued

\begin{tabular}{|c|c|c|c|}
\hline Water year & Date & $\begin{array}{l}\text { Gage height } \\
\text { (ft) }\end{array}$ & $\begin{array}{c}\text { Discharge } \\
\left(\mathrm{ft}^{3} / \mathrm{s}\right)\end{array}$ \\
\hline \multirow[t]{3}{*}{1971} & Feb. 20,1971 & ${ }^{\mathrm{a}} 18.85$ & $b_{23,000}$ \\
\hline & Mar. 14,1971 & 14.55 & 15,400 \\
\hline & June 6,1971 & 13.44 & 13,300 \\
\hline \multirow[t]{4}{*}{1972} & June 18,1972 & 10.74 & 8,840 \\
\hline & Aug. 2,1972 & 10.96 & 9,140 \\
\hline & Aug. $\quad 6,1972$ & 10.71 & 8,790 \\
\hline & Sept. 11,1972 & 11.33 & 9,730 \\
\hline \multirow[t]{12}{*}{1973} & Feb. $\quad 2,1973$ & ${ }^{a} 15.15$ & $\mathrm{~b}_{14,300}$ \\
\hline & Feb. 25,1973 & 11.00 & 9,200 \\
\hline & Mar. 7,1973 & 13.43 & 13,300 \\
\hline & Mar. 14,1973 & 14.80 & 16,000 \\
\hline & Apr. 1,1973 & 13.48 & 13,400 \\
\hline & Apr. 16,1973 & 17.59 & 22,700 \\
\hline & May 8,1973 & 17.55 & 21,600 \\
\hline & June 1,1973 & 10.68 & 8,750 \\
\hline & June 5,1973 & 11.77 & 10,400 \\
\hline & July $\quad 1,1973$ & 20.74 & 32,400 \\
\hline & July $\quad 4,1973$ & 21.74 & 35,600 \\
\hline & Sept. 29,1973 & 13.16 & 12,800 \\
\hline \multirow[t]{9}{*}{1974} & Oct. $\quad 1,1973$ & 15.33 & 17,100 \\
\hline & Oct. 11,1973 & 14.01 & 14,300 \\
\hline & Oct. 15,1973 & 11.87 & 10,600 \\
\hline & Apr. 21,1974 & 13.47 & 13,400 \\
\hline & Apr. 29,1974 & 14.33 & 15,000 \\
\hline & May 19,1974 & 20.13 & 30,400 \\
\hline & May 27,1974 & 11.95 & 11,000 \\
\hline & May 29,1974 & 10.71 & 9,380 \\
\hline & June 9,1974 & 11.87 & 11,100 \\
\hline \multirow[t]{5}{*}{1975} & Mar. 21, 1975 & 12.34 & 11,300 \\
\hline & Apr. 28,1975 & 13.90 & 14,100 \\
\hline & June 18,1975 & 14.01 & 14,300 \\
\hline & June 25,1975 & 11.92 & 10,700 \\
\hline & June 27,1975 & 10.59 & 8,630 \\
\hline \multirow[t]{2}{*}{1976} & Apr. 24,1976 & 10.69 & 8,710 \\
\hline & May 24,1976 & 12.84 & 12,200 \\
\hline \multirow[t]{2}{*}{1977} & Aug. 26, 1977 & 12.50 & 11,600 \\
\hline & Aug. 28, 1977 & 12.79 & 11,900 \\
\hline \multirow[t]{4}{*}{1978} & Mar. 22, 1978 & ${ }^{\mathrm{a}} 17.62$ & ${ }^{b} 20,800$ \\
\hline & Aug. 18, 1978 & 14.48 & 15,300 \\
\hline & Sept. 14,1978 & 13.14 & 12,800 \\
\hline & Sept. 20,1978 & 12.63 & 11,800 \\
\hline \multirow[t]{2}{*}{1979} & Mar. 19, 1979 & 20.39 & 29,900 \\
\hline & Apr. 2,1979 & 15.80 & 17,000 \\
\hline
\end{tabular}




\section{Raccoon River at Van Meter, Iowa}

Peak stages and discharges--Continued

\begin{tabular}{|c|c|c|c|}
\hline Water year & Date & $\begin{array}{l}\text { Gage height } \\
\text { (ft) }\end{array}$ & $\begin{array}{c}\text { Discharge } \\
\left(\mathrm{ft}^{3} / \mathrm{s}\right)\end{array}$ \\
\hline \multirow[t]{2}{*}{ 1979--Continued } & June 29,1979 & 11.09 & 9,340 \\
\hline & Aug. 10, 1979 & 12.25 & 11,200 \\
\hline 1980 & June 15,1980 & 7.76 & 4,870 \\
\hline 1981 & July $\quad 4,1981$ & 7.12 & 4,130 \\
\hline \multirow[t]{7}{*}{1982} & Feb. 21,1982 & ${ }^{\mathrm{a}} 14.34$ & $\mathrm{~b}_{11,600}$ \\
\hline & Feb. 23,1982 & 12.25 & 11,500 \\
\hline & Mar. 20, 1982 & 12.14 & 11,300 \\
\hline & May 20,1982 & 12.86 & 12,700 \\
\hline & May 26,1982 & 12.41 & 11,800 \\
\hline & June 15,1982 & 14.21 & 15,100 \\
\hline & June 16,1982 & 10.92 & 9,390 \\
\hline \multirow[t]{12}{*}{1983} & Dec. 28,1982 & 12.78 & 12,200 \\
\hline & Feb. 20,1983 & 13.66 & 13,700 \\
\hline & Mar. 11,1983 & 14.28 & 14,900 \\
\hline & Mar. 16, 1983 & 10.53 & 8,520 \\
\hline & Apr. 2,1983 & 14.00 & 14,400 \\
\hline & Apr. 10,1983 & 12.73 & 12,000 \\
\hline & Apr. 17,1983 & 14.08 & 14,500 \\
\hline & May 7,1983 & 13.64 & 13,700 \\
\hline & May 19,1983 & 11.61 & 10,200 \\
\hline & June 26,1983 & 12.70 & 12,100 \\
\hline & June 30,1983 & 16.25 & 19,400 \\
\hline & July 3,1983 & 18.59 & 25,500 \\
\hline \multirow[t]{12}{*}{1984} & Feb. 12,1984 & 13.61 & 13,900 \\
\hline & Feb. 19,1984 & 11.61 & 10,800 \\
\hline & Apr. 12,1984 & 11.64 & 10,200 \\
\hline & Apr. 16,1984 & 11.21 & 9,550 \\
\hline & Apr. 30,1984 & 19.51 & 28,500 \\
\hline & May 25,1984 & 11.94 & 10,700 \\
\hline & May 29,1984 & 11.39 & 9,830 \\
\hline & June 8,1984 & 10.73 & 8,790 \\
\hline & June 9,1984 & 13.45 & 13,300 \\
\hline & June 13,1984 & 13.31 & 13,100 \\
\hline & June 17,1984 & 18.09 & 24,000 \\
\hline & June 23,1984 & 17.50 & 22,400 \\
\hline 1985 & Feb. 22,1985 & ${ }^{\mathrm{a}} 12.70$ & 9,900 \\
\hline \multirow[t]{7}{*}{1986} & May 11,1986 & 13.92 & 14,300 \\
\hline & May 17,1986 & 15.20 & 17,000 \\
\hline & July $\quad 1,1986$ & 22.69 & 40,200 \\
\hline & July 10,1986 & 11.28 & 9,880 \\
\hline & July 11,1986 & 11.07 & 9,520 \\
\hline & July 14,1986 & 11.39 & 9,990 \\
\hline & Aug. 14, 1986 & 14.14 & 14,400 \\
\hline
\end{tabular}




\section{Raccoon River at Van Meter, Iowa}

Peak stages and discharges--Continued

\begin{tabular}{|c|c|c|c|}
\hline Water year & Date & $\begin{array}{c}\text { Gage height } \\
\text { (ft) }\end{array}$ & $\begin{array}{c}\text { Discharge } \\
\left(\mathrm{ft}^{3} / \mathrm{s}\right)\end{array}$ \\
\hline \multirow[t]{3}{*}{1987} & Oct. 12,1986 & 12.42 & 11,500 \\
\hline & July 12,1987 & 10.64 & 8,730 \\
\hline & Aug. 26, 1987 & 13.97 & 14,700 \\
\hline \multirow[t]{2}{*}{1988} & Feb. 21,1988 & ${ }^{a} 11.66$ & - \\
\hline & June 9,1988 & 7.16 & 3,920 \\
\hline \multirow[t]{2}{*}{1989} & Mar. 10, 1989 & ${ }^{\mathrm{a}} 11.00$ & - \\
\hline & Sept. 9,1989 & ${ }^{c} 9.98$ & 7,640 \\
\hline \multirow[t]{3}{*}{1990} & May 21,1990 & 12.27 & 11,300 \\
\hline & May 28,1990 & 13.60 & 13,600 \\
\hline & June 16,1990 & 21.39 & 34,600 \\
\hline \multirow[t]{9}{*}{1991} & Mar. 27, 1991 & 11.82 & 10,900 \\
\hline & Apr. 19,1991 & 16.78 & 21,000 \\
\hline & Apr. 29,1991 & 14.10 & 15,000 \\
\hline & May 9,1991 & 12.24 & 11,600 \\
\hline & May 21,1991 & 12.37 & 11,800 \\
\hline & June 2,1991 & 13.36 & 13,600 \\
\hline & June 7,1991 & 16.64 & 20,600 \\
\hline & June 14,1991 & 15.94 & 18,900 \\
\hline & June 15,1991 & 15.67 & 18,300 \\
\hline \multirow[t]{3}{*}{1992} & Apr. 23,1992 & 11.50 & 10,400 \\
\hline & July 26,1992 & 10.49 & 8,850 \\
\hline & Sept. 16, 1992 & 12.69 & 12,400 \\
\hline \multirow[t]{10}{*}{1993} & Mar. 9, 1993 & 14.01 & 14,400 \\
\hline & Mar. 30, 1993 & 14.55 & 15,500 \\
\hline & Apr. 25,1993 & 12.80 & 12,200 \\
\hline & June 20,1993 & 13.62 & 13,700 \\
\hline & July 1,1993 & 13.59 & 13,600 \\
\hline & July 10,1993 & 26.34 & 70,100 \\
\hline & Aug. 12, 1993 & 15.48 & 17,400 \\
\hline & Aug. 18, 1993 & 14.60 & 15,600 \\
\hline & Aug. 29, 1993 & 21.15 & 33,900 \\
\hline & Sept. 25,1993 & 12.01 & 10,800 \\
\hline \multirow[t]{2}{*}{1994} & Feb. 19,1994 & ${ }^{\mathrm{a}} 12.64$ & -- \\
\hline & Mar. 7, 1994 & 10.42 & 8,750 \\
\hline \multirow[t]{3}{*}{1995} & Apr. 27,1995 & 11.38 & 9,320 \\
\hline & May 11,1995 & 12.40 & 10,800 \\
\hline & May 28,1995 & 13.12 & 12,400 \\
\hline \multirow[t]{4}{*}{1996} & Feb. $\quad 9,1996$ & "14.92 & - \\
\hline & May 10,1996 & 12.82 & 12,000 \\
\hline & May 24,1996 & 16.47 & 17,400 \\
\hline & May 28,1996 & 13.34 & 12,700 \\
\hline
\end{tabular}




\section{Raccoon River at Van Meter, Iowa}

Peak stages and discharges--Continued

\begin{tabular}{cccc}
\hline Water year & Date & $\begin{array}{c}\text { Gage height } \\
(\mathbf{f t})\end{array}$ & $\begin{array}{c}\text { Discharge } \\
\left(\mathrm{ft}^{\mathbf{3}} / \mathbf{s}\right)\end{array}$ \\
\hline 1996--Continued & June 22, 1996 & 15.73 & 16,100 \\
& July 18,1996 & 13.62 & 13,100 \\
& Aug. 6,1996 & 11.82 & 10.600 \\
\hline
\end{tabular}

affected by ice.

${ }^{\mathrm{b}}$ Approximate.

${ }^{\mathrm{c}}$ Gage height determined from floodmark.

${ }^{\text {s}}$ Peak for 1915 is from April to September 30. 


\section{Raccoon River at 63rd Street, Des Moines, Iowa}

Location.--Lat 41'33'49", long 9342'13", in SW1/4 NE1/4 sec. 14, T.78 N., R. 25 W., Polk County, Hydrologic Unit 07100006, on left bank, at upstream side of bridge on State Highway 28, 2.9 mi upstream from Walnut Creek, 8.6 mi upstream from mouth.

Drainage area.--3,529 $\mathrm{mi}^{2}$.

Gage.--Water-stage recorder. Datum is $774.91 \mathrm{ft}$ above sea level.

Stage-discharge relation.--As of September 30, 1996, stage-discharge relation not defined, only gage heights are published.

Bankfull stage.--36 ft.

Remarks.--Only annual peak stages are shown.

\section{Peak stages}

[Water year, October 1-September 30; ft, feet above gage datum; --, not determined]

\begin{tabular}{ccc}
\hline Water year & Date & $\begin{array}{c}\text { Gage height } \\
\text { (ft) }\end{array}$ \\
\hline 1992 & Sept. 16, 1992 & - \\
1993 & July 11, 1993 & $\mathrm{c}_{40.77}$ \\
1994 & Feb. 19, 1994 & $\mathrm{a}_{32.82}$ \\
1995 & May 29, 1995 & 31.00 \\
1996 & June 22,1996 & 33.12 \\
\hline
\end{tabular}

${ }^{\mathrm{a} A f f e c t e d}$ by ice.

${ }^{\mathrm{c}} \mathrm{Gage}$ height determined from floodmark. 


\section{Walnut Creek at Des Moines, Iowa}

Location.--Lat $41^{\circ} 35^{\prime} 14^{\prime \prime}$, long 93²' 11", in SW1/4 SE1/4 sec. 2, T.78 N., R. 25 W., Polk County, Hydrologic Unit 07100006, on left bank, $25 \mathrm{ft}$ downstream from bridge on 63rd Street in Des Moines, and $2.2 \mathrm{mi}$ upstream from Raccoon River.

Drainage area.--78.4 $\mathrm{mi}^{2}$.

Gage.--Water-stage recorder. Datum is $801.04 \mathrm{ft}$ above sea level (levels by Iowa Natural Resources Council).

Stage-discharge relation.--Defined by current-meter measurements.

Flood stage.--13 ft.

Remarks.--Base for partial-duration series, $600 \mathrm{ft}^{3} / \mathrm{s}$.

Peak stages and discharges

[Water year, October 1-September 30; ft, feet above gage datum; $\mathrm{ft}^{3} / \mathrm{s}$, cubic feet per second; --, not determined]

\begin{tabular}{|c|c|c|c|}
\hline Water year & Date & $\begin{array}{c}\text { Gage height } \\
\text { (ft) }\end{array}$ & $\begin{array}{c}\text { Discharge } \\
\left(\mathrm{ft}^{3} / \mathrm{s}\right)\end{array}$ \\
\hline \multirow[t]{2}{*}{1972} & June 20,1972 & 9.53 & 680 \\
\hline & Sept. 10,1972 & 8.86 & 644 \\
\hline \multirow[t]{7}{*}{1973} & Dec. 30,1972 & ${ }^{\mathrm{a}} 10.39$ & 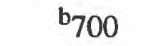 \\
\hline & Feb. $\quad 1,1973$ & 14.00 & 2,350 \\
\hline & Apr. 16,1973 & 11.85 & 1,610 \\
\hline & May 1,1973 & 9.70 & 942 \\
\hline & May 8,1973 & 9.99 & 878 \\
\hline & July 1,1973 & 17.72 & 9,000 \\
\hline & July $\quad 4,1973$ & 12.56 & 1,670 \\
\hline \multirow[t]{4}{*}{1974} & Oct. 11,1973 & 12.74 & 1,770 \\
\hline & Apr. 28,1974 & 12.73 & 1,740 \\
\hline & May 19,1974 & 12.78 & 1,760 \\
\hline & June 9,1974 & 17.44 & 8,160 \\
\hline \multirow[t]{5}{*}{1975} & Apr. 27,1975 & 9.08 & 736 \\
\hline & June 15,1975 & 8.82 & 670 \\
\hline & June 18,1975 & 11.53 & 1,440 \\
\hline & Aug. 27,1975 & 17.00 & 5,800 \\
\hline & Aug. 29,1975 & 10.19 & 948 \\
\hline \multirow[t]{6}{*}{1976} & Apr. 18,1976 & 14.24 & 2,470 \\
\hline & Apr. 24,1976 & 12.20 & 1,530 \\
\hline & June 10,1976 & 10.13 & 928 \\
\hline & June 12,1976 & 9.82 & 875 \\
\hline & June 13,1976 & 9.05 & 686 \\
\hline & June 28,1976 & 13.41 & 2,060 \\
\hline \multirow[t]{4}{*}{1977} & Aug. 26, 1977 & 11.84 & 1,400 \\
\hline & Aug. 28, 1977 & 14.48 & 2,590 \\
\hline & Aug. 31, 1977 & 9.43 & 746 \\
\hline & Sept. 17,1977 & 8.70 & 602 \\
\hline
\end{tabular}




\section{Walnut Creek at Des Moines, Iowa}

Peak stages and discharges--Continued

\begin{tabular}{|c|c|c|c|}
\hline Water year & Date & $\begin{array}{c}\text { Gage height } \\
\text { (ft) }\end{array}$ & $\begin{array}{c}\text { Discharge } \\
\left(\mathrm{ft}^{3} / \mathrm{s}\right)\end{array}$ \\
\hline \multirow[t]{5}{*}{1978} & Mar. 20,1978 & 8.80 & 620 \\
\hline & Apr. 17,1978 & 9.99 & 933 \\
\hline & Apr. 17,1978 & 10.75 & 1,180 \\
\hline & Aug. 27,1978 & 10.32 & 965 \\
\hline & Sept. 20,1978 & 8.62 & 616 \\
\hline \multirow[t]{4}{*}{1979} & June 13,1979 & 10.30 & 1,010 \\
\hline & Aug. 10, 1979 & 9.59 & 855 \\
\hline & Aug. 19, 1979 & 8.72 & 662 \\
\hline & Aug. 21, 1979 & 8.77 & 672 \\
\hline \multirow[t]{3}{*}{1980} & June 1,1980 & 8.60 & 674 \\
\hline & June 4,1980 & 9.28 & 827 \\
\hline & Aug. 16,1980 & 9.80 & 954 \\
\hline \multirow[t]{6}{*}{1981} & May 23,1981 & 11.93 & 1,560 \\
\hline & June 24,1981 & 11.49 & 1,420 \\
\hline & July $\quad 3,1981$ & 13.47 & 2,190 \\
\hline & July 17,1981 & 11.44 & 1,440 \\
\hline & Aug. 14,1981 & 12.25 & 1,700 \\
\hline & Aug. 28, 1981 & 8.45 & 643 \\
\hline \multirow[t]{8}{*}{1982} & Feb. 23,1982 & a.- & ${ }^{b} 821$ \\
\hline & Mar. 19, 1982 & 8.58 & 702 \\
\hline & Apr. 16,1982 & 8.79 & 766 \\
\hline & June 15,1982 & 9.65 & 989 \\
\hline & July $\quad 6,1982$ & 9.39 & 920 \\
\hline & July 18,1982 & 11.41 & 1,440 \\
\hline & July 21,1982 & 8.56 & 668 \\
\hline & Aug. 5,1982 & 12.08 & 1,650 \\
\hline \multirow[t]{9}{*}{1983} & Dec. 27,1982 & 8.84 & 757 \\
\hline & Apr. 12,1983 & 8.67 & 728 \\
\hline & May 7,1983 & 9.21 & 899 \\
\hline & May 19,1983 & 8.56 & 740 \\
\hline & June 9,1983 & 8.01 & 618 \\
\hline & June 29,1983 & 11.60 & 1,490 \\
\hline & July 2,1983 & 9.00 & 771 \\
\hline & July $\quad 3,1983$ & 12.64 & 1,840 \\
\hline & Aug. 30,1983 & 8.30 & 609 \\
\hline \multirow[t]{7}{*}{1984} & Nov. 3,1983 & 8.41 & 700 \\
\hline & Nov. 19,1983 & 8.14 & 638 \\
\hline & Apr. 29,1984 & 9.85 & 989 \\
\hline & May 25,1984 & 10.38 & 1,130 \\
\hline & May 28,1984 & 9.01 & 774 \\
\hline & June 8,1984 & 12.58 & 1,820 \\
\hline & June 9,1984 & 14.63 & 2,820 \\
\hline
\end{tabular}


05484800 Walnut Creek at Des Moines, Iowa

Peak stages and discharges--Continued

\begin{tabular}{|c|c|c|c|}
\hline Water year & Date & $\begin{array}{l}\text { Gage height } \\
\text { (ft) }\end{array}$ & $\begin{array}{c}\text { Discharge } \\
\left(\mathrm{ft}^{3} / \mathrm{s}\right)\end{array}$ \\
\hline \multirow[t]{4}{*}{ 1984--Continued } & June 11,1984 & 10.75 & 1,240 \\
\hline & June 14,1984 & 10.56 & 1,180 \\
\hline & July 14,1984 & 12.07 & 1,640 \\
\hline & July 26,1984 & 10.77 & 1,240 \\
\hline \multirow[t]{2}{*}{1985} & Nov. 1,1984 & 9.69 & 946 \\
\hline & Sept. 22,1985 & 9.02 & 776 \\
\hline \multirow[t]{11}{*}{1986} & Apr. 30,1986 & 14.37 & 3,160 \\
\hline & May 8,1986 & 8.21 & 669 \\
\hline & May 10,1986 & 18.32 & 12,500 \\
\hline & May 13,1986 & 7.88 & 687 \\
\hline & May 17,1986 & 10.43 & 1,450 \\
\hline & May 25,1986 & 11.46 & 1,820 \\
\hline & June 4,1986 & 10.12 & 1,340 \\
\hline & June 30,1986 & 14.88 & 3,450 \\
\hline & July 10,1986 & 9.75 & 1,220 \\
\hline & July 29,1986 & 7.63 & 625 \\
\hline & Aug. 13,1986 & 12.18 & 2,090 \\
\hline \multirow[t]{8}{*}{1987} & Apr. 14,1987 & 8.09 & 740 \\
\hline & June 18,1987 & 8.09 & 735 \\
\hline & June 25,1987 & 7.75 & 645 \\
\hline & July 8,1987 & 8.92 & 964 \\
\hline & July 12,1987 & 11.87 & 1,970 \\
\hline & Aug. 8,1987 & 8.02 & 732 \\
\hline & Aug. 25, 1987 & 9.50 & 1,150 \\
\hline & Aug. 26, 1987 & 10.42 & 1,440 \\
\hline \multirow[t]{2}{*}{1988} & June 8,1988 & 7.58 & 613 \\
\hline & Aug. 22, 1988 & 7.95 & 704 \\
\hline \multirow[t]{5}{*}{1989} & Nov. 15,1988 & 8.69 & 899 \\
\hline & May 24,1989 & 8.41 & 824 \\
\hline & July 18,1989 & 8.76 & 924 \\
\hline & Aug. 29,1989 & 7.66 & 642 \\
\hline & Sept. 9,1989 & 8.36 & 822 \\
\hline \multirow[t]{10}{*}{1990} & Mar. 13,1990 & 11.61 & 2,070 \\
\hline & May 25,1990 & 8.19 & 766 \\
\hline & June 16,1990 & 18.00 & 7,780 \\
\hline & June 19,1990 & 9.68 & 1,200 \\
\hline & June 22,1990 & 7.89 & 689 \\
\hline & June 28,1990 & 8.71 & 907 \\
\hline & July $\quad 5,1990$ & 7.64 & 628 \\
\hline & July 19,1990 & 10.76 & 1,560 \\
\hline & July 26,1990 & 7.74 & 652 \\
\hline & July 27,1990 & 10.97 & 1,640 \\
\hline
\end{tabular}




\section{Walnut Creek at Des Moines, Iowa}

Peak stages and discharges--Continued

\begin{tabular}{|c|c|c|c|}
\hline Water year & Date & $\begin{array}{c}\text { Gage height } \\
\text { (ft) }\end{array}$ & $\begin{array}{c}\text { Discharge } \\
\left(\mathrm{ft}^{3} / \mathrm{s}\right)\end{array}$ \\
\hline \multirow[t]{11}{*}{1991} & Apr. 12,1991 & 7.71 & 652 \\
\hline & Apr. 14,1991 & 8.34 & 806 \\
\hline & Apr. 18,1991 & 7.82 & 677 \\
\hline & May 14,1991 & 7.56 & 621 \\
\hline & May 29,1991 & 11.56 & 1,850 \\
\hline & May 31,1991 & 8.66 & 893 \\
\hline & June 4,1991 & 13.95 & 2,890 \\
\hline & June 11,1991 & 7.94 & 702 \\
\hline & June 14,1991 & 8.10 & 742 \\
\hline & June 15,1991 & 8.60 & 876 \\
\hline & Aug. 8,1991 & 12.35 & 2,160 \\
\hline \multirow[t]{4}{*}{1992} & Nov. 1,1991 & 7.08 & 602 \\
\hline & July $\quad 2,1992$ & 7.38 & 674 \\
\hline & July 24,1992 & 10.10 & 1,450 \\
\hline & Sept. 9,1992 & 7.17 & 624 \\
\hline \multirow[t]{20}{*}{1993} & Mar. 4,1993 & 9.00 & 1,110 \\
\hline & May 3,1993 & 7.52 & 709 \\
\hline & May 8,1993 & 7.34 & 664 \\
\hline & May 11,1993 & 9.07 & 1,130 \\
\hline & May 29,1993 & 7.17 & 624 \\
\hline & June 19,1993 & 7.79 & 777 \\
\hline & June 29,1993 & 8.34 & 922 \\
\hline & June 30,1993 & 9.17 & 1,160 \\
\hline & July 5,1993 & 7.10 & 607 \\
\hline & July 8,1993 & 9.63 & 1,300 \\
\hline & July 9,1993 & 15.74 & 4,110 \\
\hline & July 11,1993 & 12.10 & 2,140 \\
\hline & July 13,1993 & 9.47 & 1,260 \\
\hline & July 25,1993 & 8.98 & 1,110 \\
\hline & Aug. 10, 1993 & 10.22 & 1,490 \\
\hline & Aug. 11, 1993 & 12.69 & 2,370 \\
\hline & Aug. 13, 1993 & 7.50 & 731 \\
\hline & Aug. 18, 1993 & 7.06 & 628 \\
\hline & Aug. 29, 1993 & 17.56 & 6,460 \\
\hline & Sept. 25,1993 & 12.93 & 2,460 \\
\hline \multirow[t]{4}{*}{1994} & July 11,1994 & 7.46 & 704 \\
\hline & July 12,1994 & 7.48 & 706 \\
\hline & Aug. 30,1994 & 7.89 & 792 \\
\hline & Sept. 4,1994 & 7.39 & 667 \\
\hline \multirow[t]{3}{*}{1995} & Apr. 26,1995 & 7.38 & 650 \\
\hline & May 9,1995 & 10.12 & 1,450 \\
\hline & June 27,1995 & 8.68 & 1,030 \\
\hline
\end{tabular}




\section{Walnut Creek at Des Moines, Iowa}

Peak stages and discharges--Continued

\begin{tabular}{ccrr}
\hline Water year & Date & $\begin{array}{c}\text { Gage height } \\
(\mathbf{f t})\end{array}$ & $\begin{array}{c}\text { Discharge } \\
\left(\mathrm{ft}^{3} / \mathbf{s}\right)\end{array}$ \\
\hline 1996 & May 8, 1996 & 6.86 & 802 \\
& May 10, 1996 & 12.60 & 3,430 \\
& May 14, 1996 & 6.50 & 684 \\
& May 24, 1996 & 13.24 & 3,850 \\
& May 27, 1996 & 6.97 & 839 \\
& June 1, 1996 & 7.49 & 1,030 \\
& July 17, 1996 & 11.43 & 2,750 \\
& Sept. 23, 1996 & 6.38 & 645 \\
& Sept. 26, 1996 & 8.17 & 1,290 \\
\hline
\end{tabular}

${ }^{a}$ Affected by ice

${ }^{\mathrm{b}}$ Approximate. 


\section{Raccoon River at Fleur Drive, Des Moines, Iowa}

Location.--Lat $41^{\circ} 34^{\prime} 54^{\prime \prime}$, long 93³8'34", in NW1/4 NE1/4 sec. 8, T.78 N., R. 24 W., Polk County, Hydrologic Unit 07100006, on downstream side of Fleur Drive bridge (SW 18th Street) attached to handrail $465 \mathrm{ft}$ from right edge of bridge, $3.0 \mathrm{mi}$ downstream from Walnut Creek, $2.6 \mathrm{mi}$ upstream from mouth.

Drainage area.--3,625 $\mathrm{mi}^{2}$.

Gage.--Water-stage recorder. Datum is $780.696 \mathrm{ft}$ above sea level.

Stage-discharge relation.--As of September 30, 1996, stage-discharge relation not defined, only gage heights are published.

Flood stage.--12 ft.

Remarks.--Only annual peak stages are shown.

Peak stages

[Water year, October 1-September 30; ft, feet above gage datum; --, not determined]

\begin{tabular}{|c|c|c|}
\hline Water year & Date & $\begin{array}{l}\text { Gage height } \\
\text { (ft) }\end{array}$ \\
\hline 1984 & June 18,1984 & 16.34 \\
\hline 1985 & Feb. 23,1985 & ${ }^{a} 7.90$ \\
\hline 1986 & July $\quad 2,1986$ & 19.38 \\
\hline 1987 & Aug. 27,1987 & 12.39 \\
\hline 1988 & ${ }^{\mathrm{b}} \mathrm{Feb} .22,1988$ & - \\
\hline 1989 & Sept. 9,1989 & 7.85 \\
\hline 1990 & June 17,1990 & 19.42 \\
\hline 1991 & June 8,1991 & 15.36 \\
\hline 1992 & Sept. 16, 1992 & -- \\
\hline 1993 & July 11,1993 & ${ }^{c_{26.8}}$ \\
\hline 1994 & ${ }^{\mathrm{b}}$ Mar. $\quad 7,1994$ & -- \\
\hline 1995 & May 29,1995 & 11.34 \\
\hline 1996 & June 22,1996 & 13.67 \\
\hline
\end{tabular}

"Affected by ice.

${ }^{\mathrm{b}}$ Approximate.

${ }^{\mathrm{c}}$ Gage height determined from floodmark. 
(bLANK PAGE)

- 80- 


\section{APPENDIX B}

\section{WATER-SURFACE-ELEVATION PROFILES FOR THE RACCOON RIVER BASIN, WEST-CENTRAL IOWA}


(BCANK PAGE) 82 - 


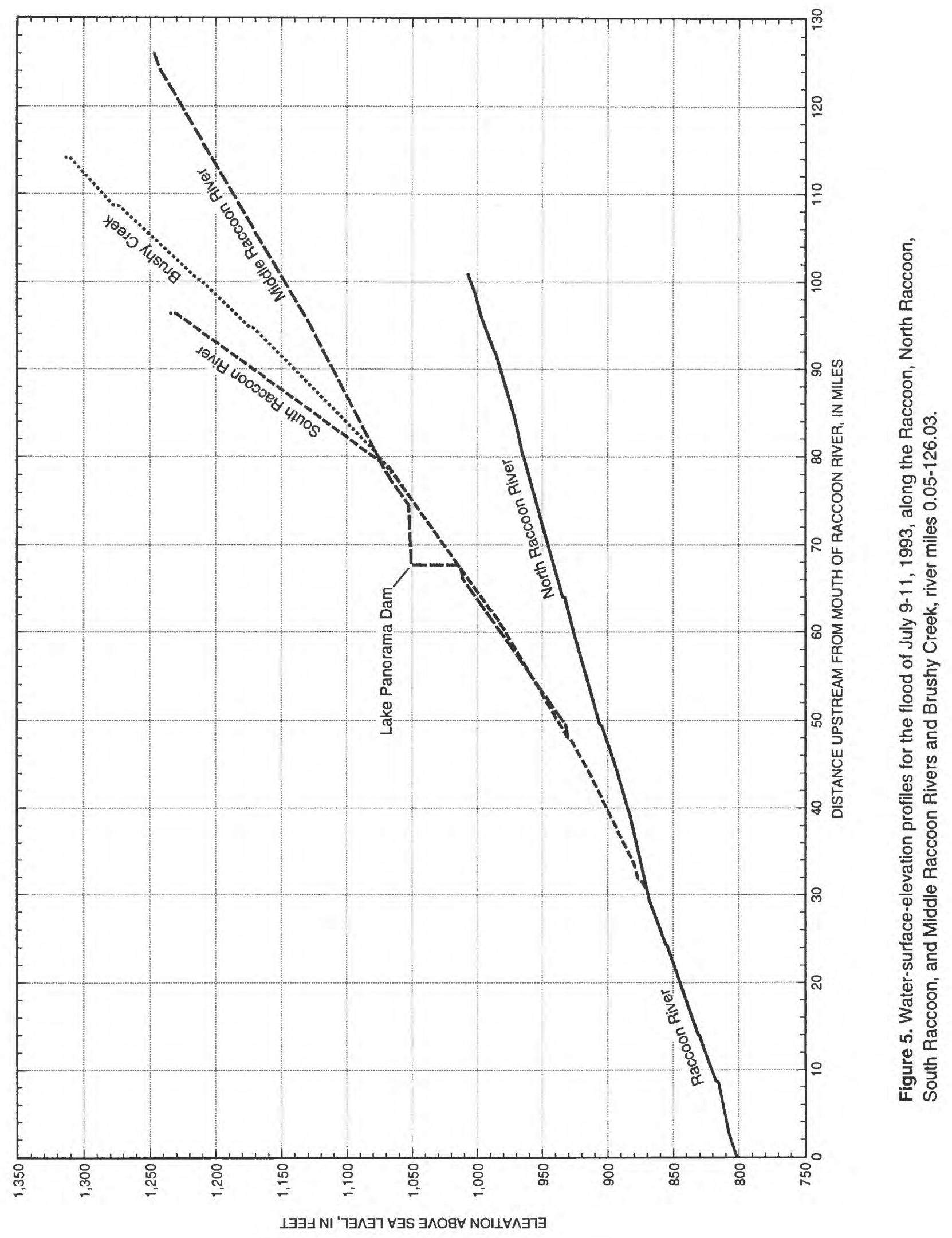




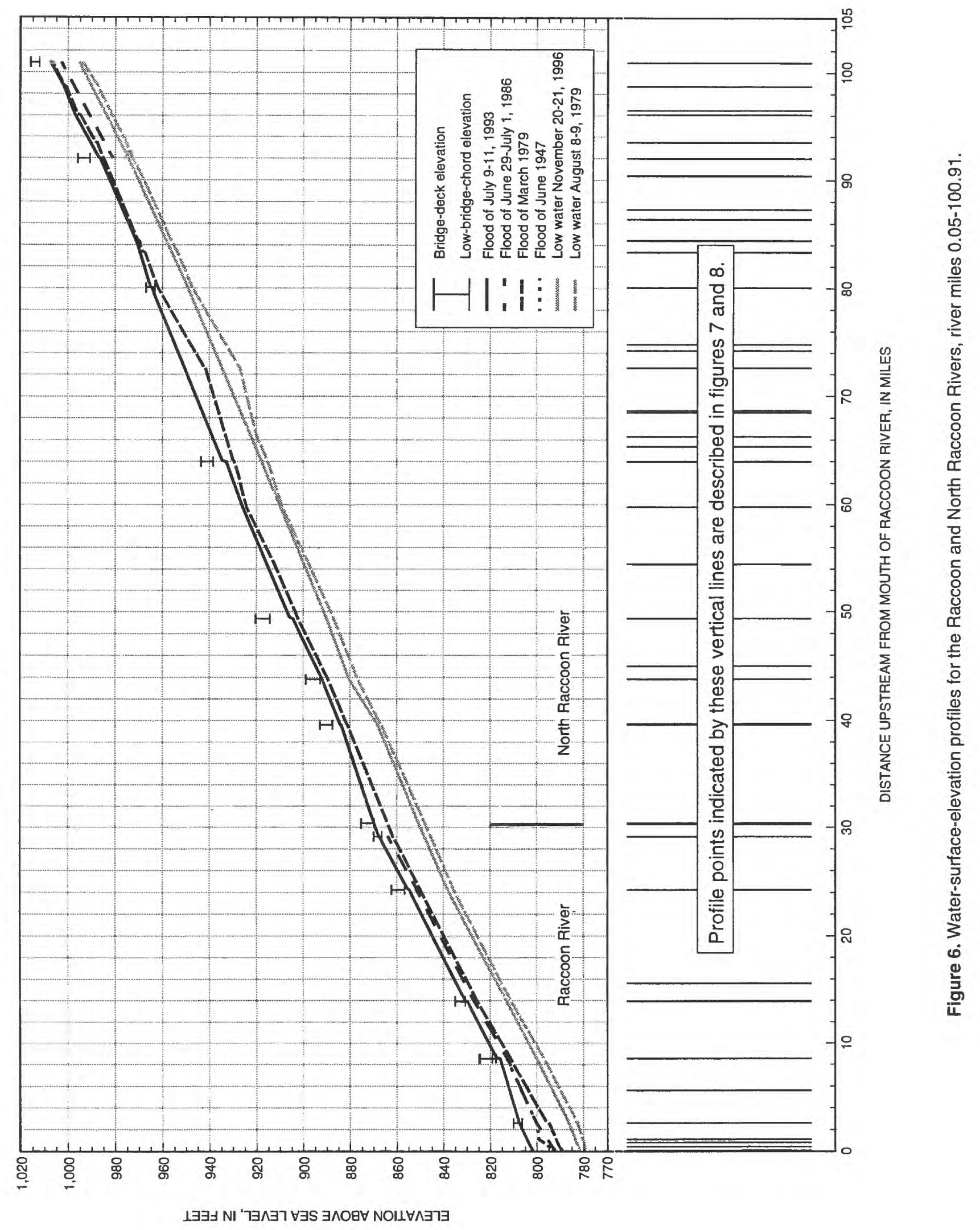




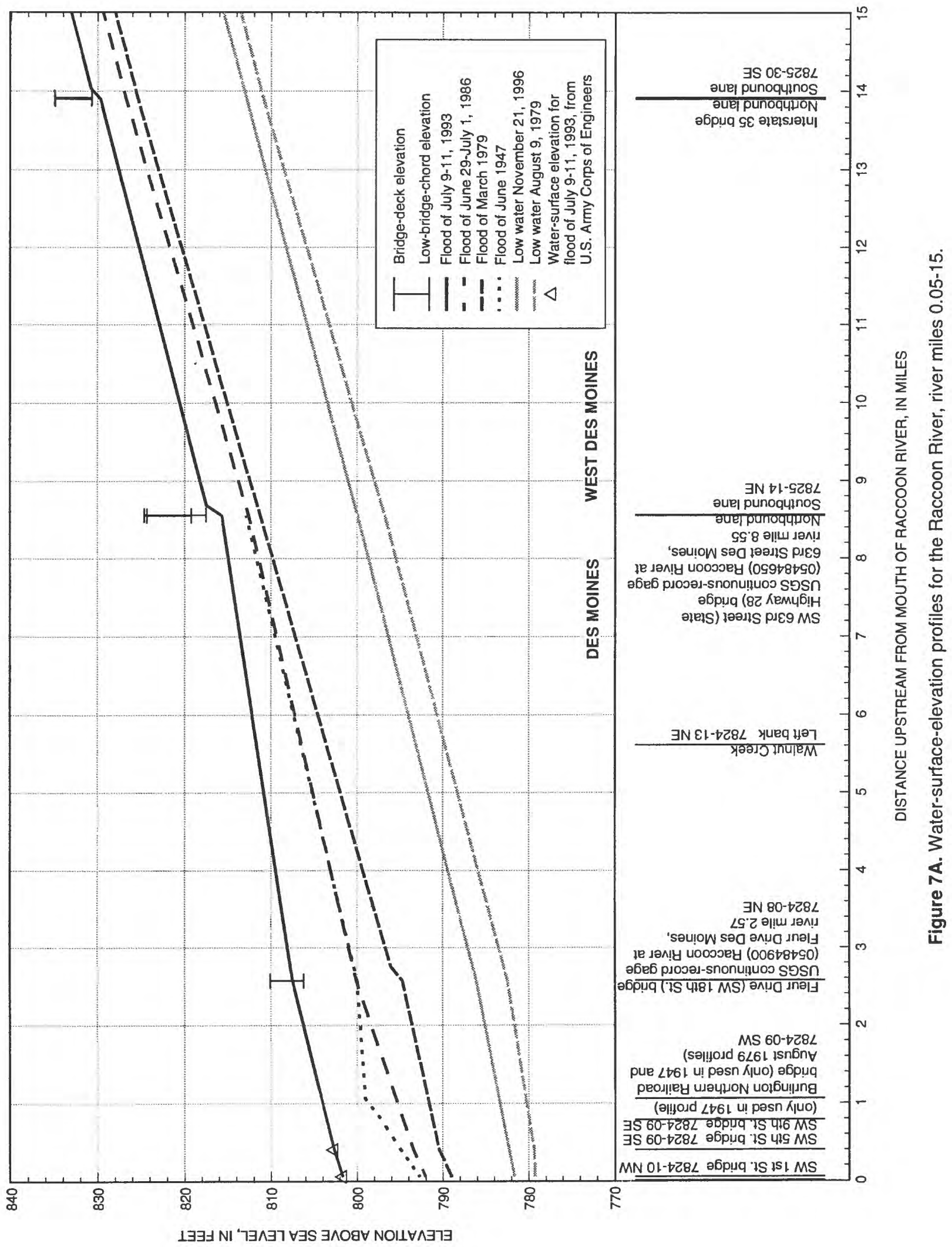




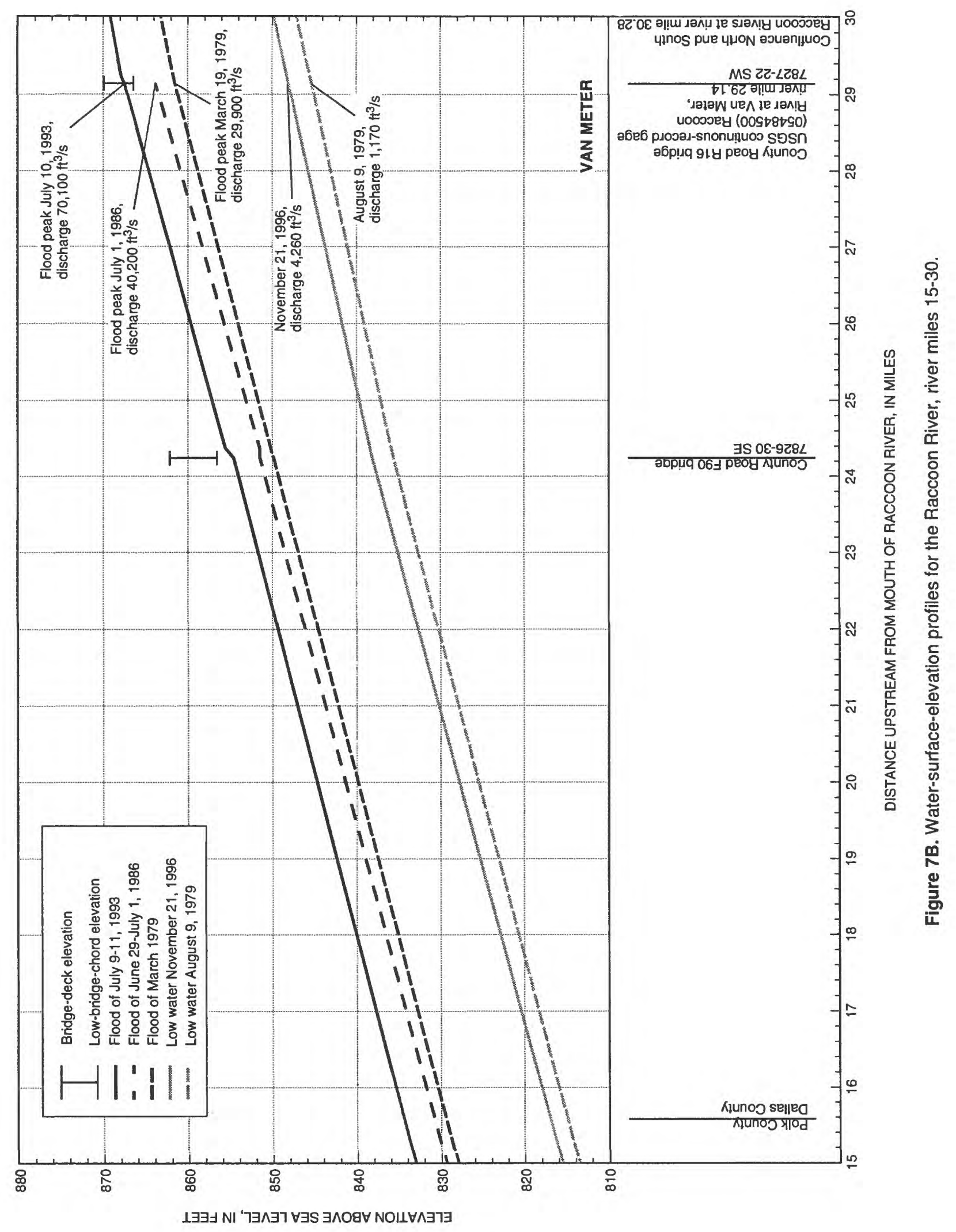




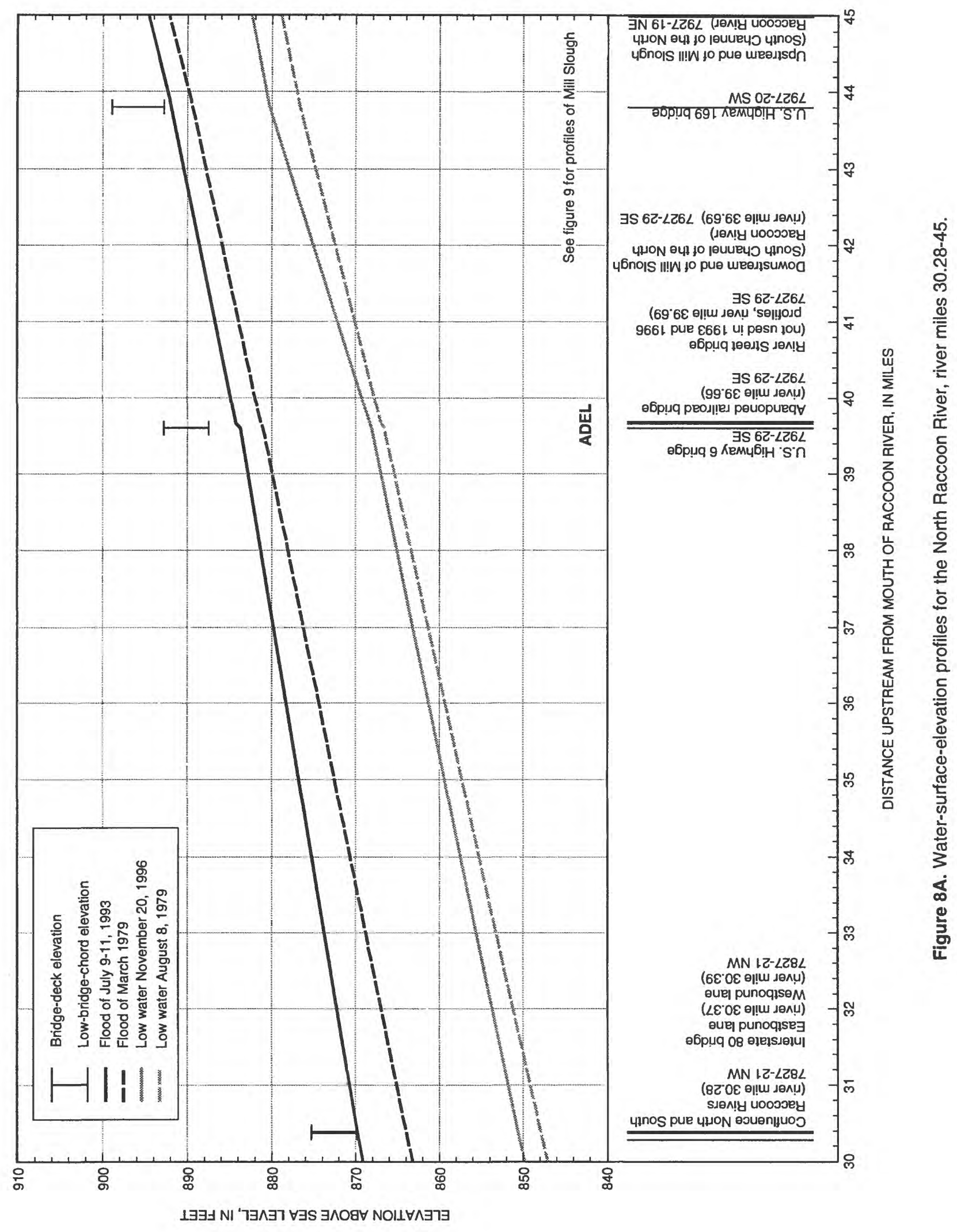




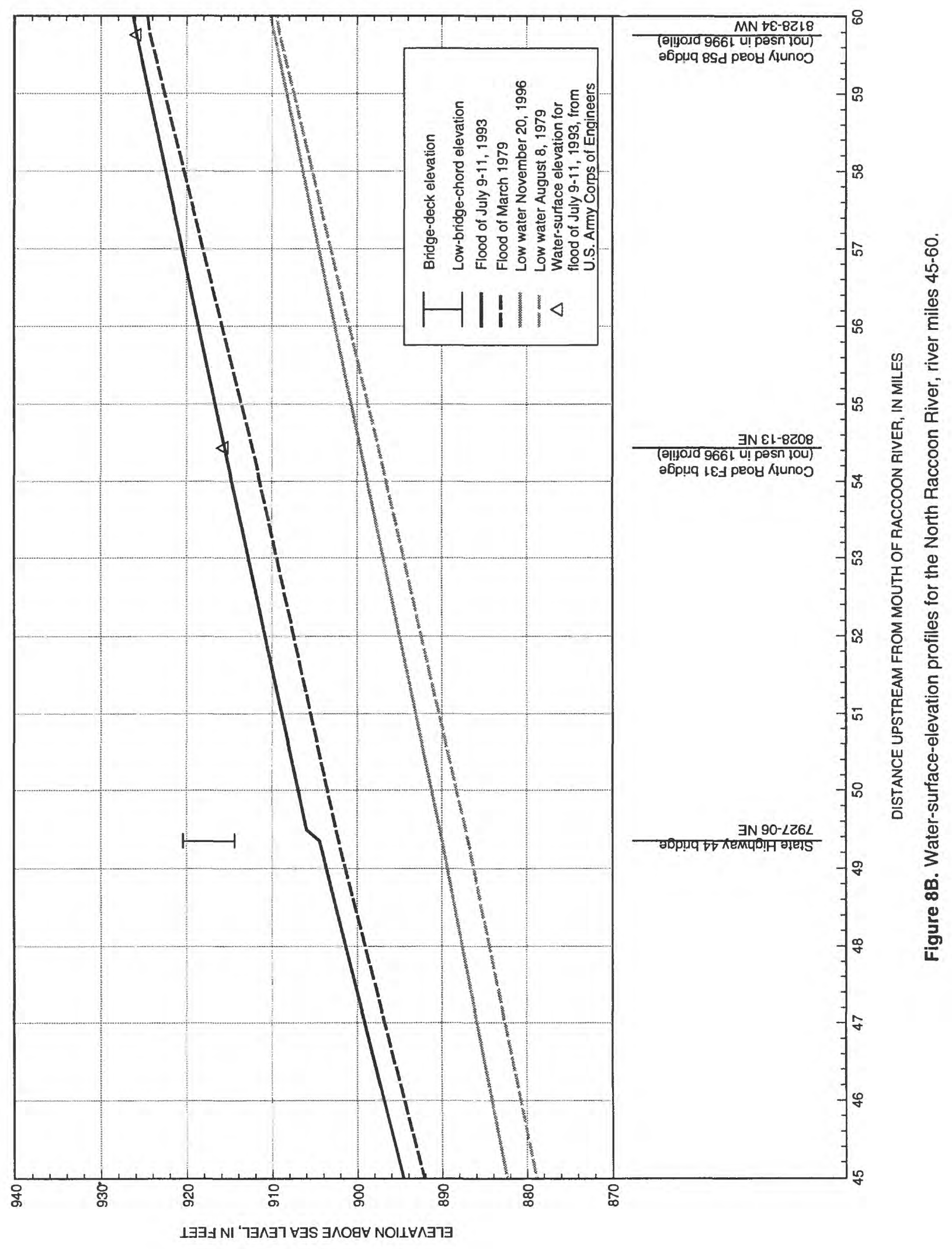




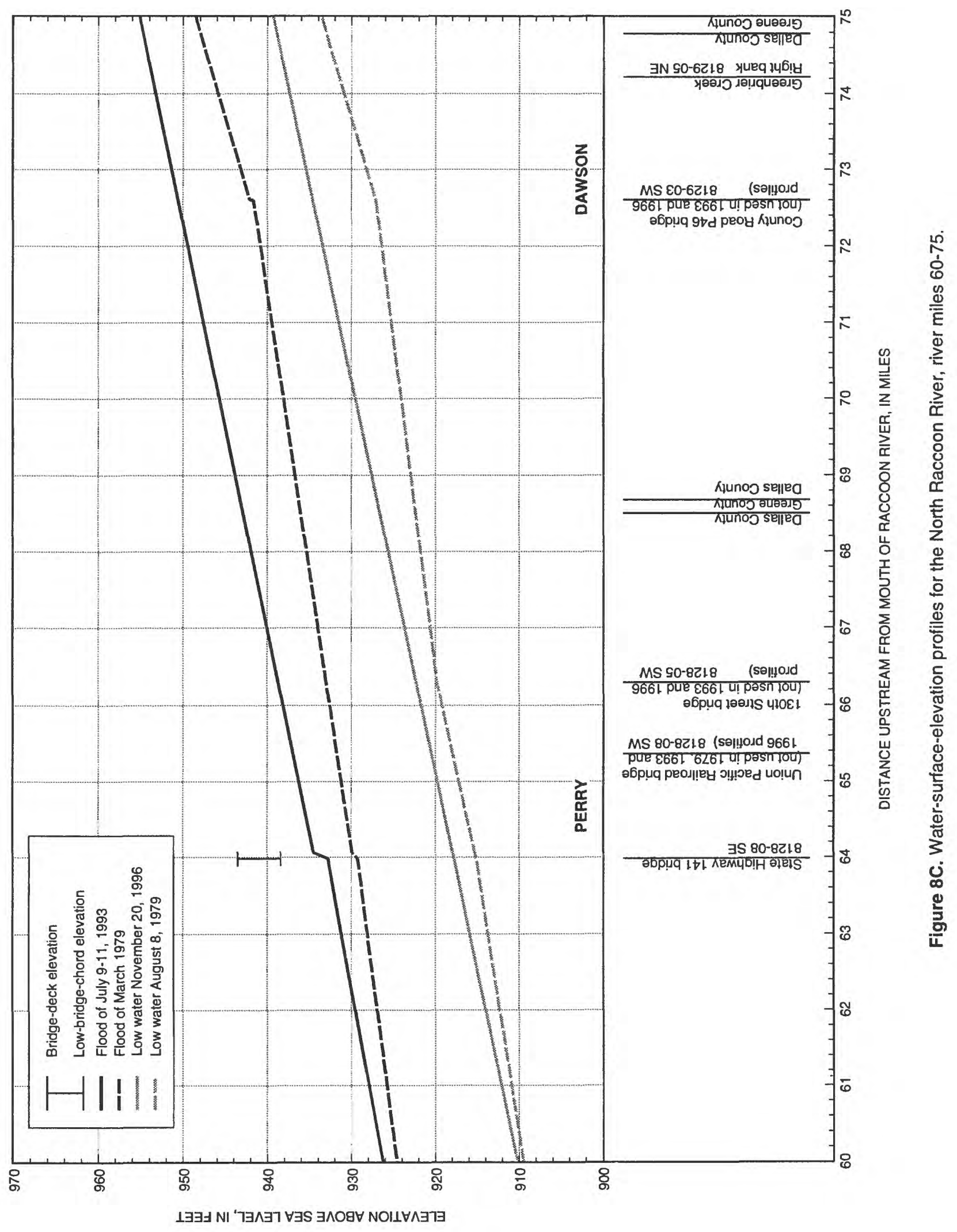




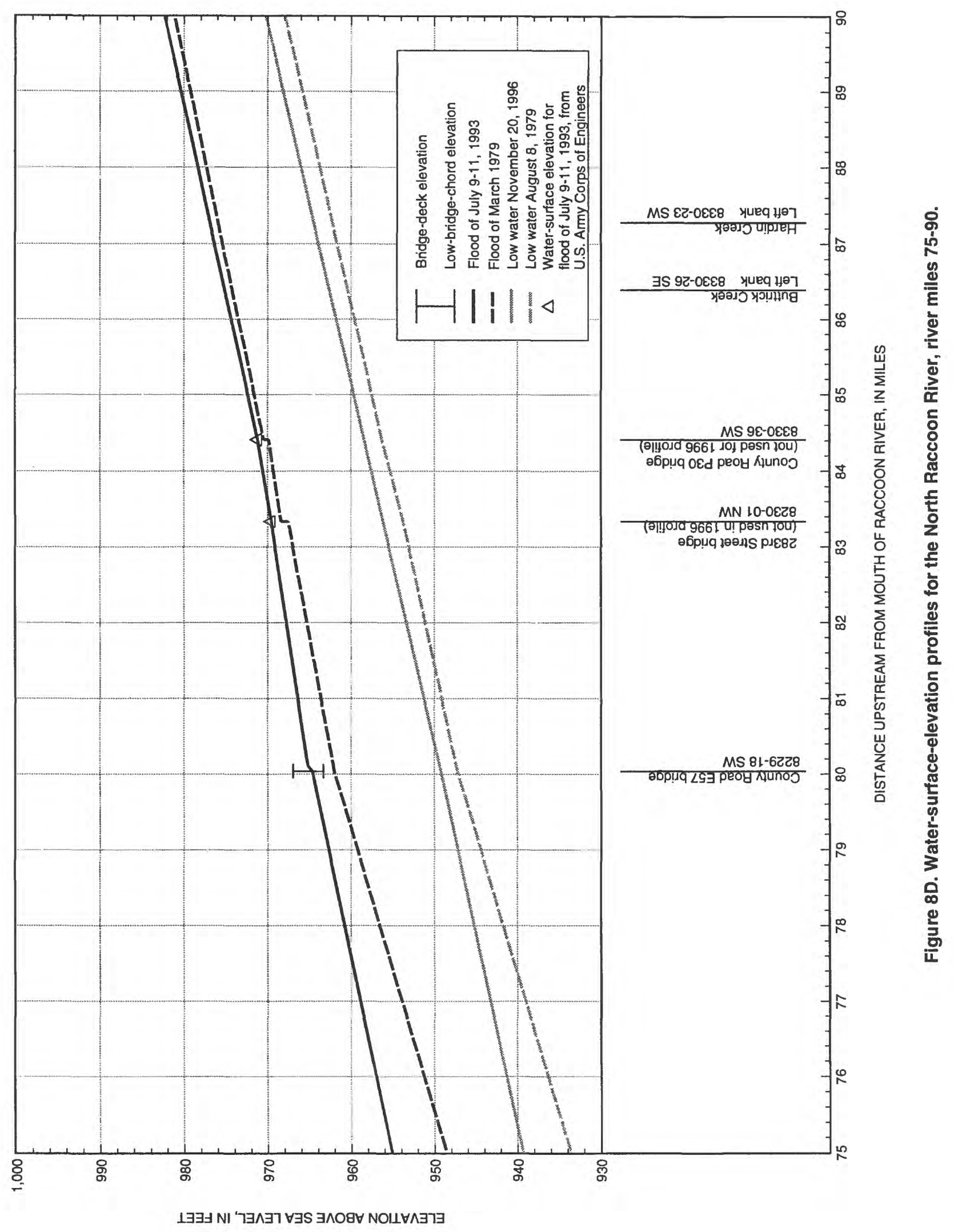




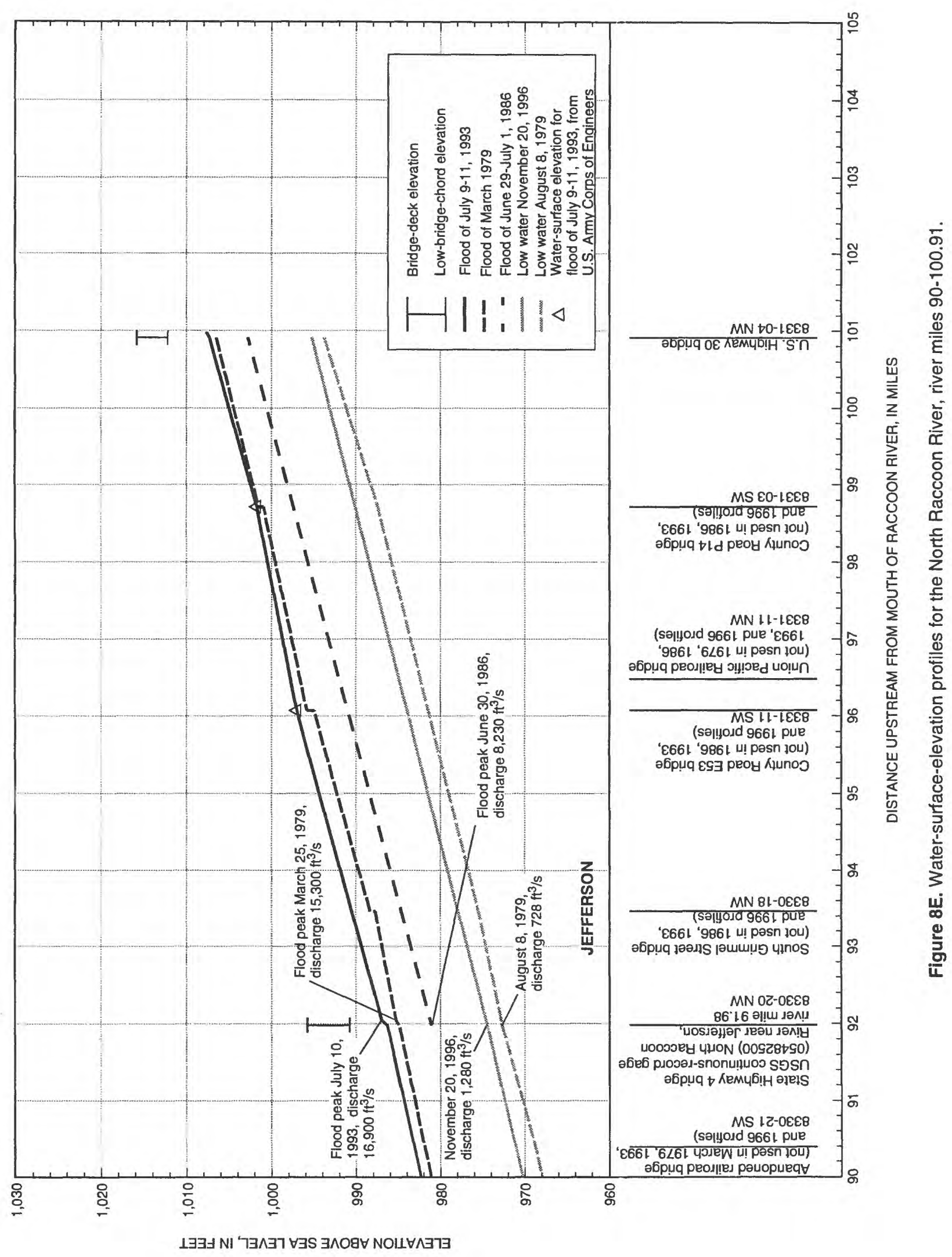




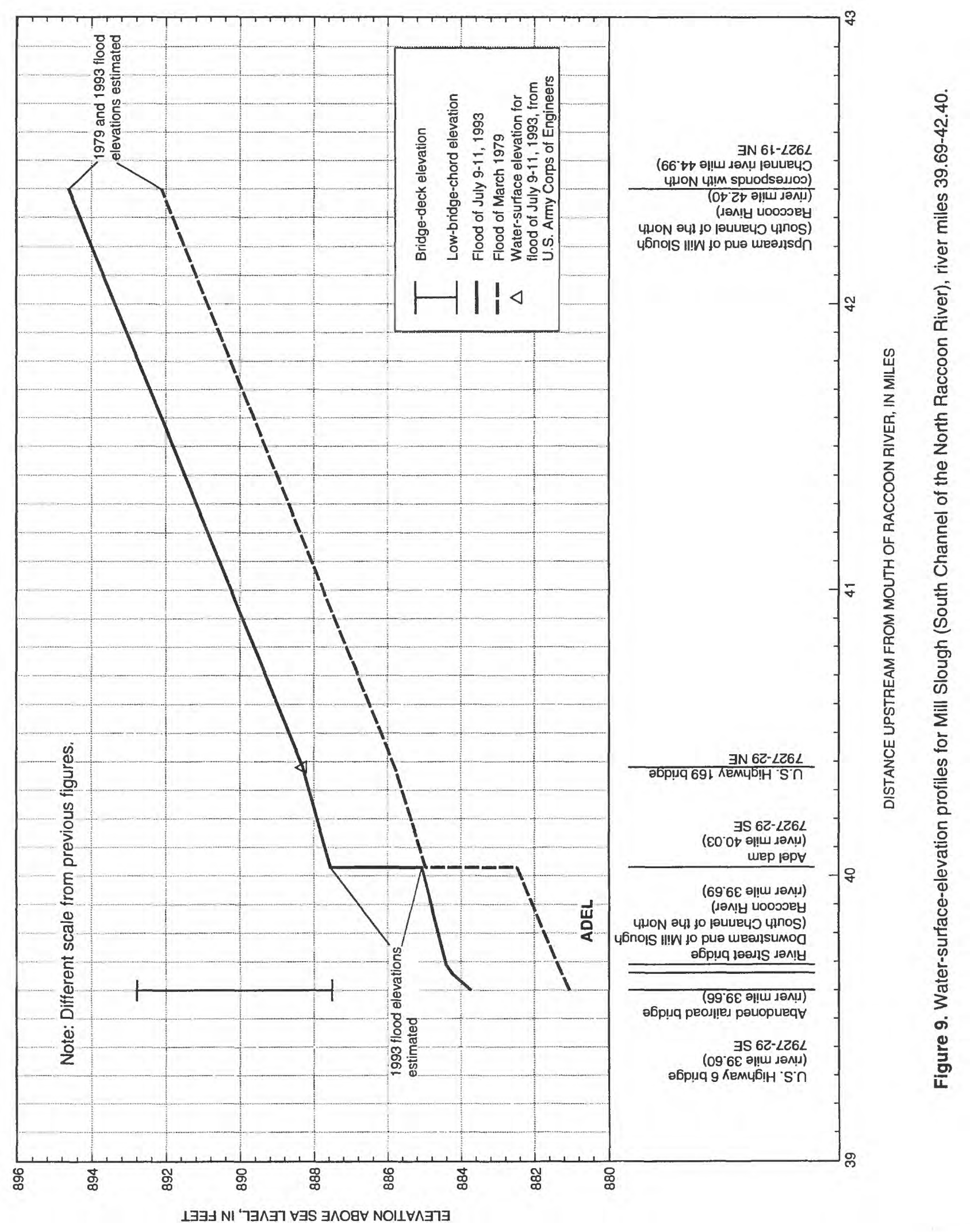




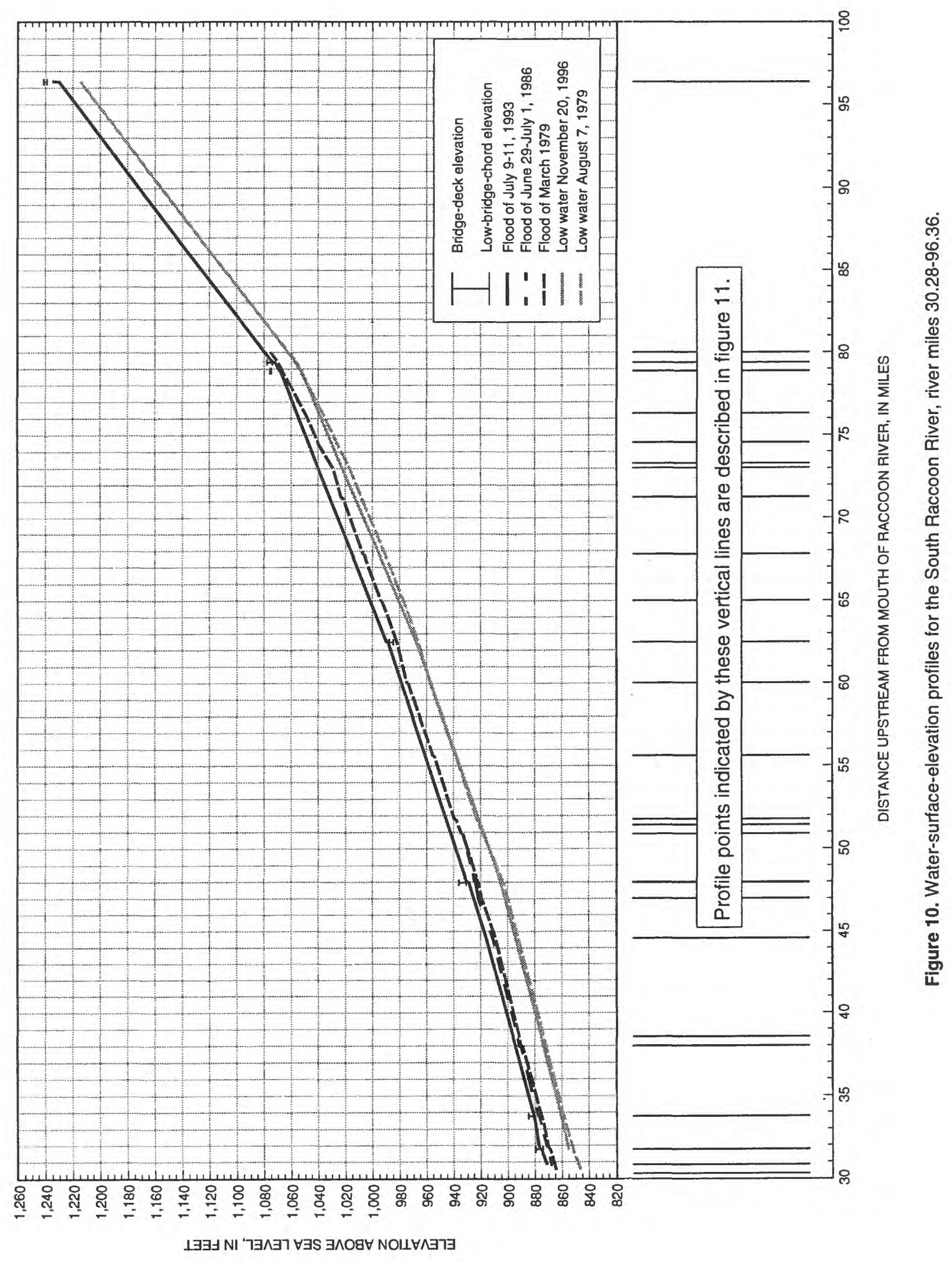




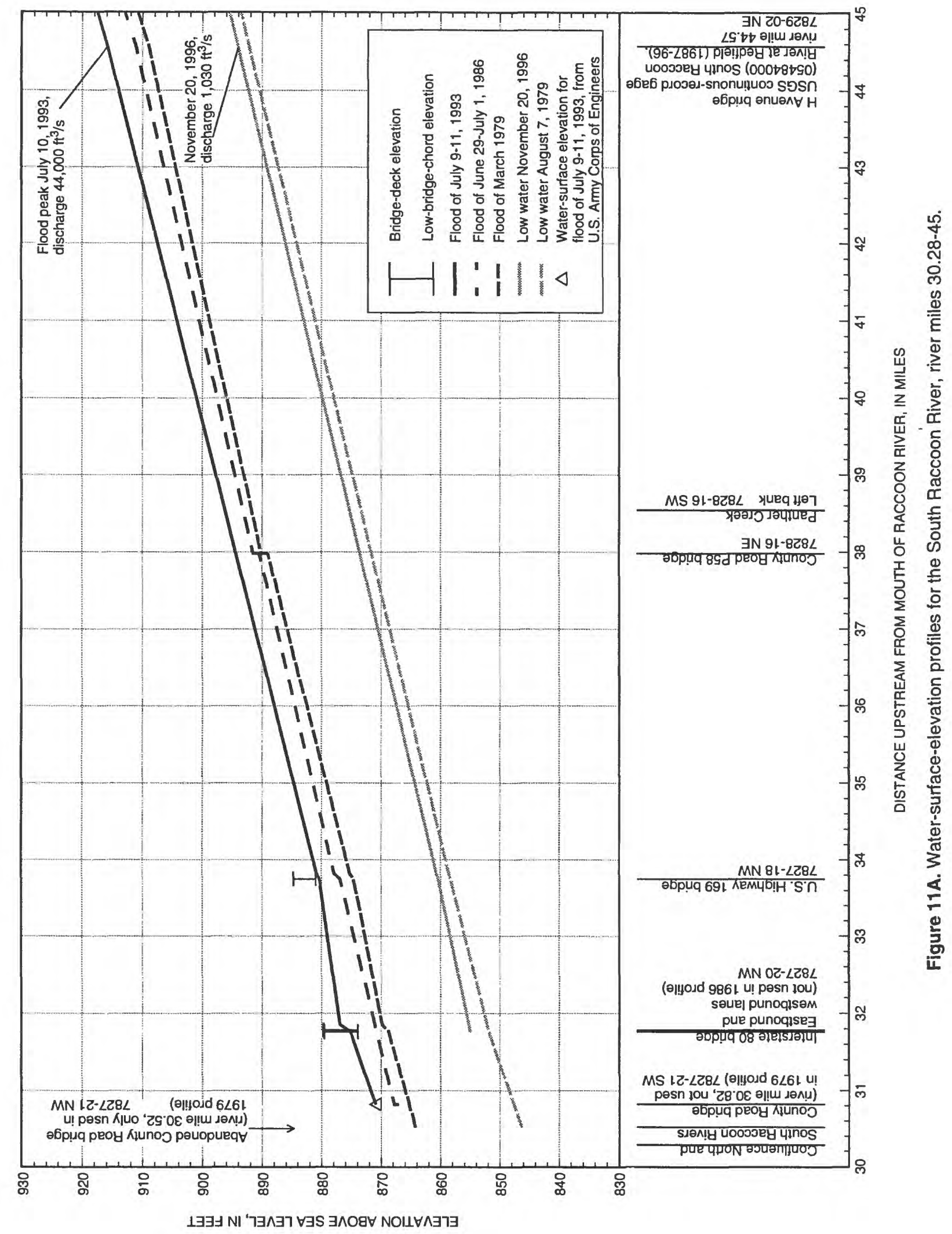




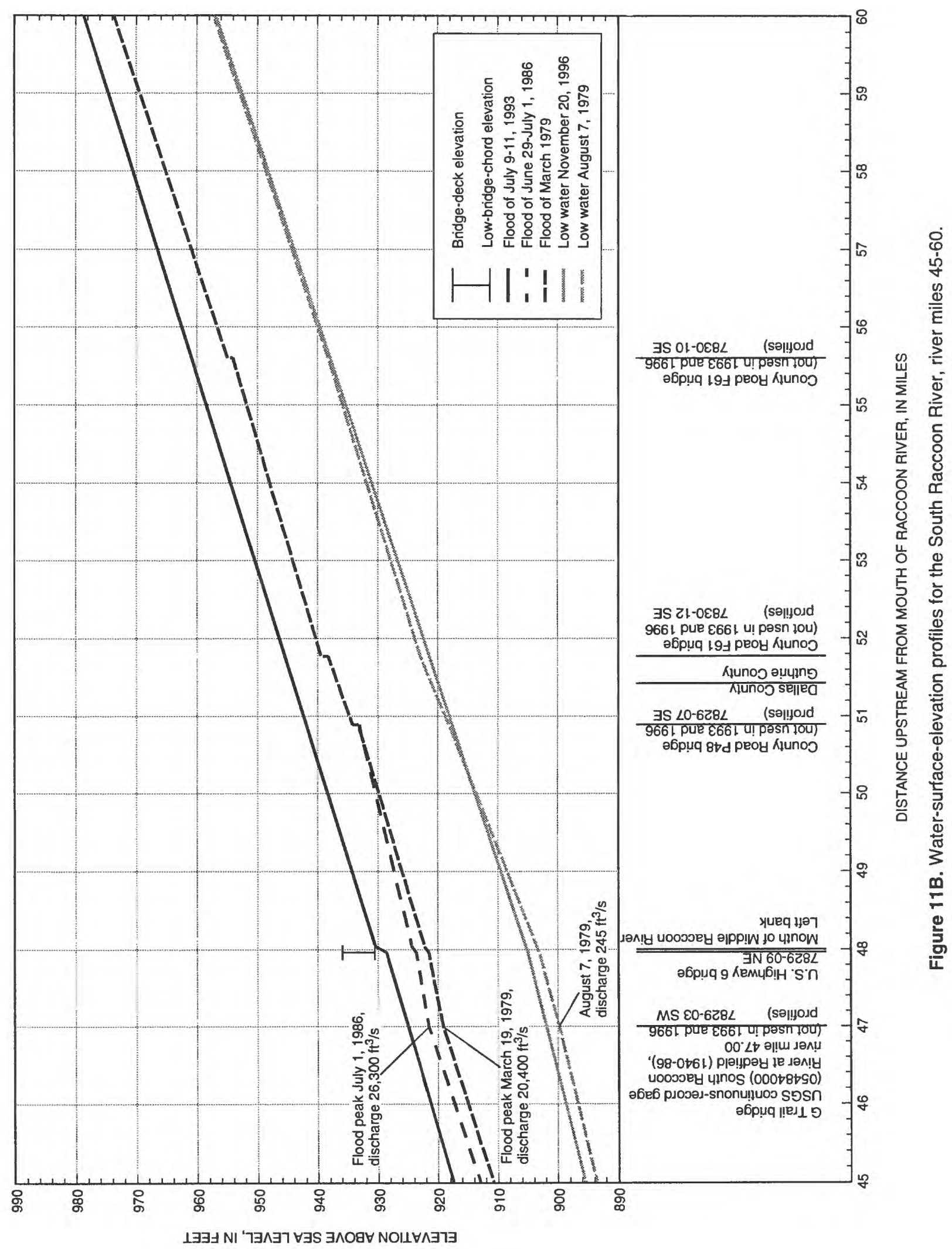




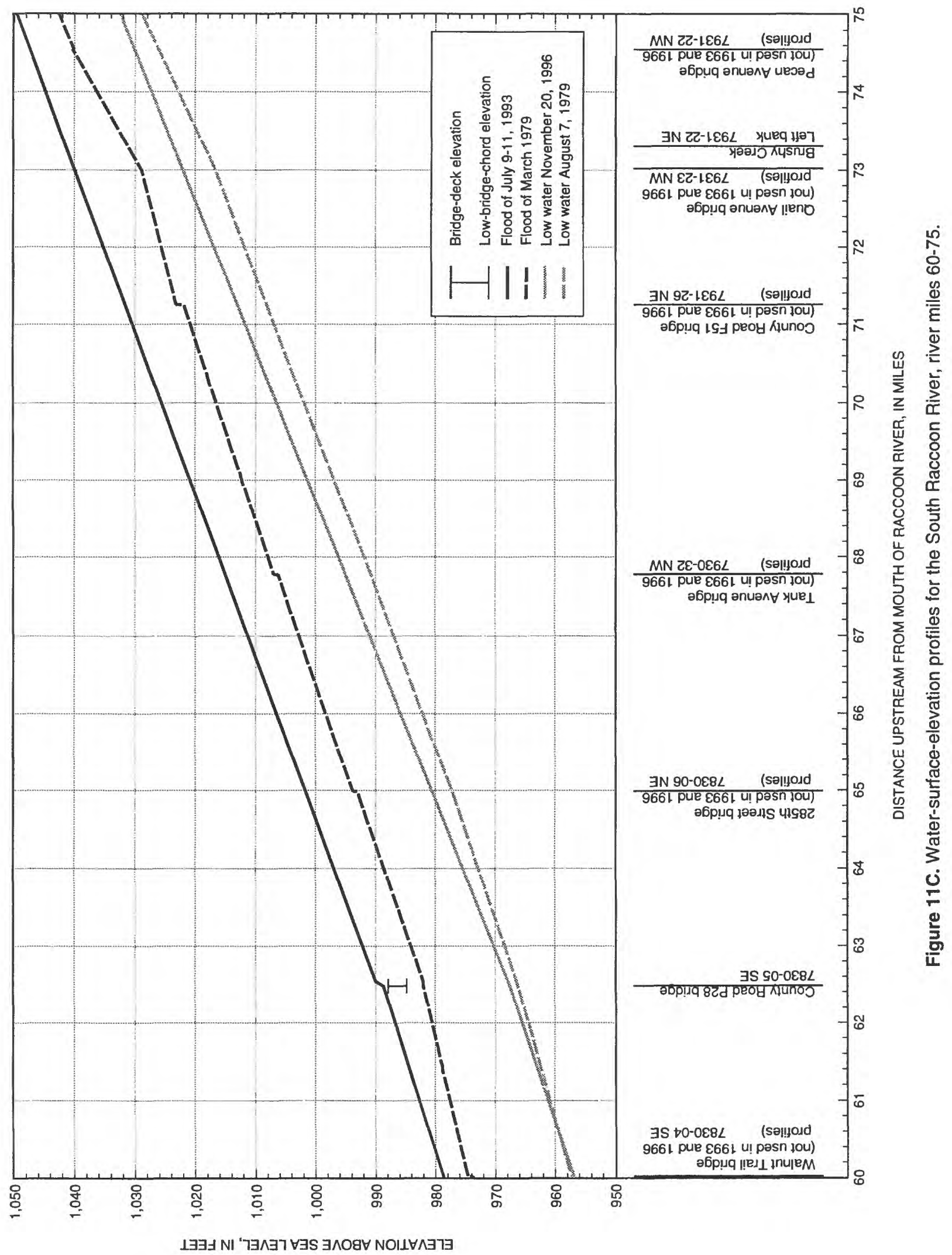




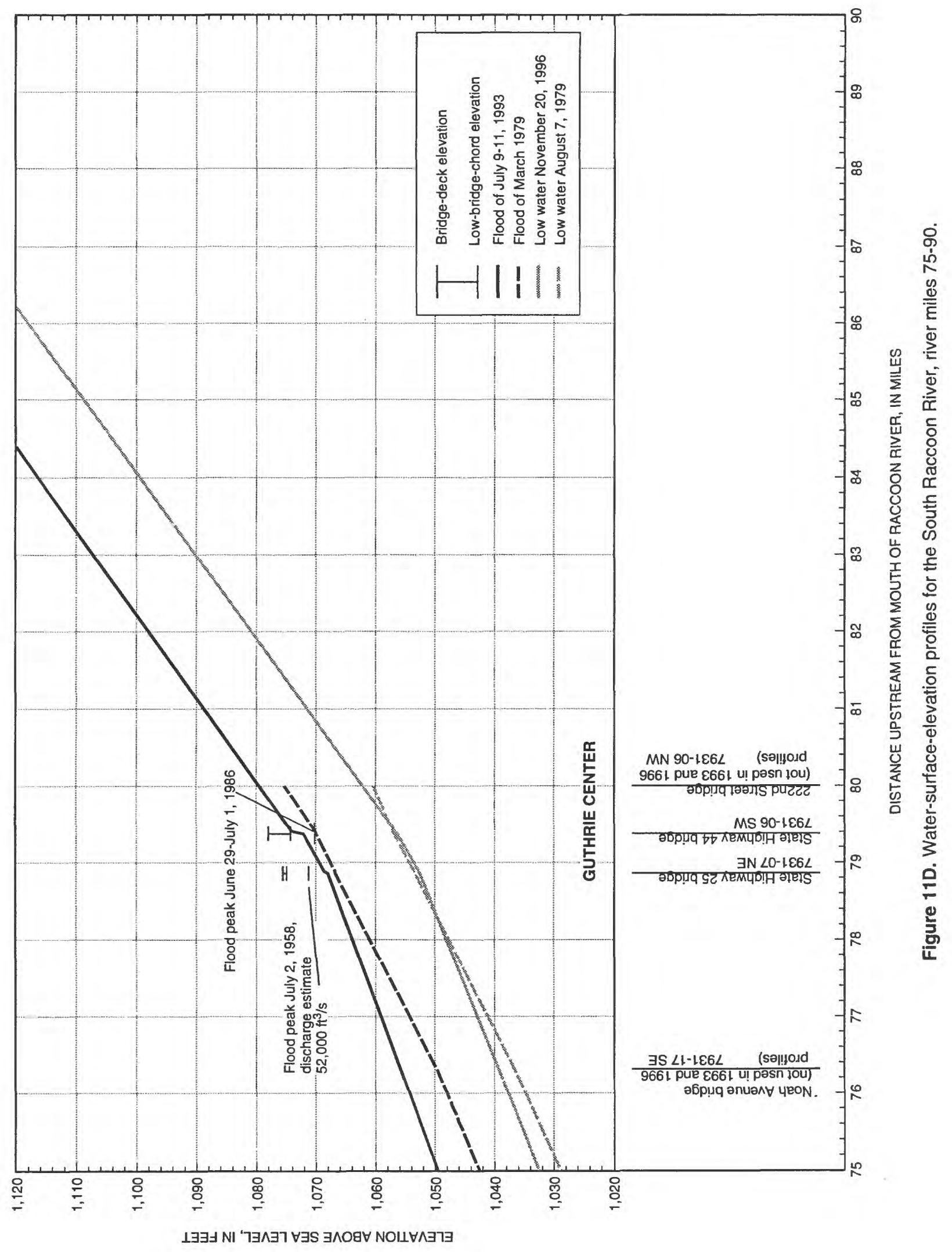




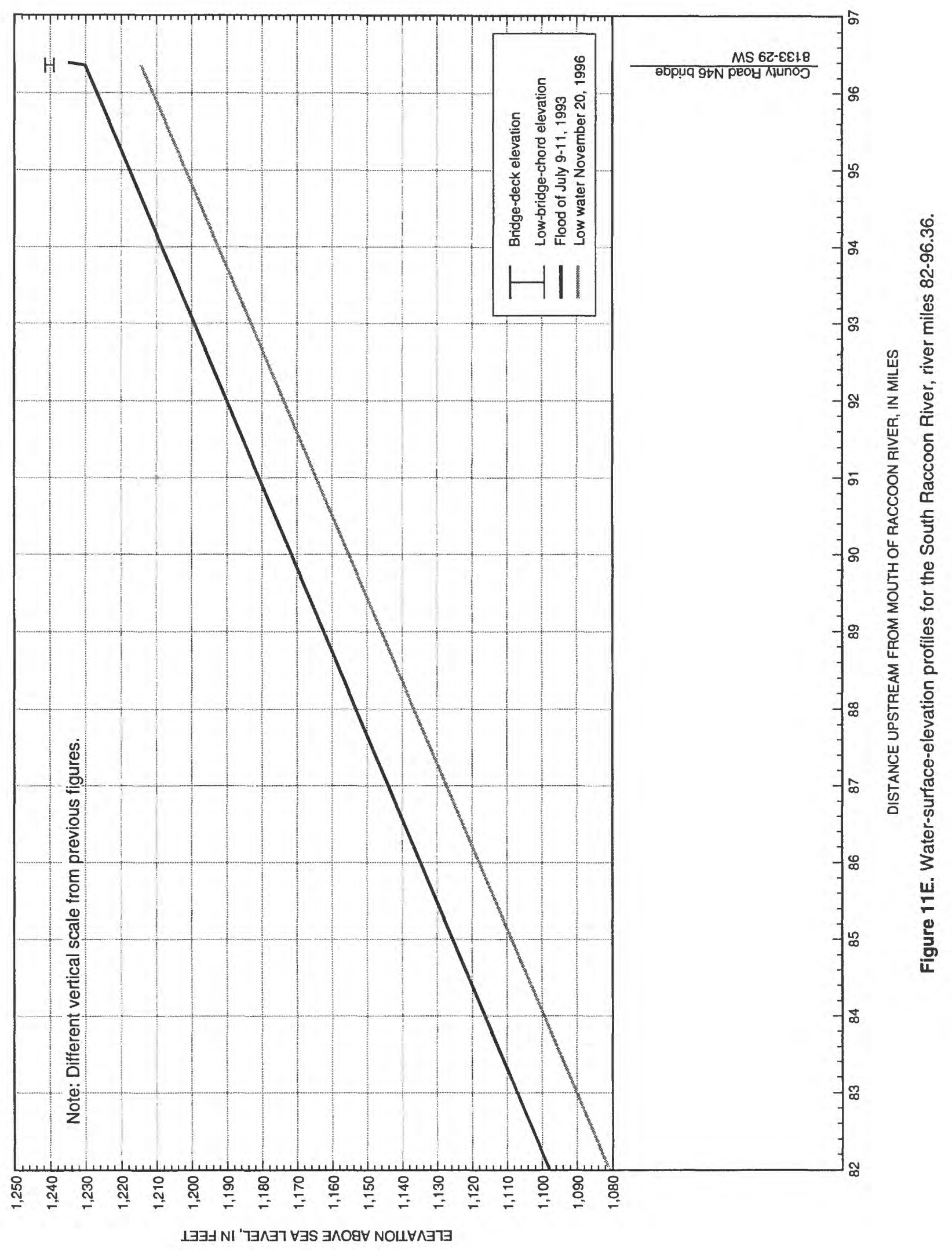




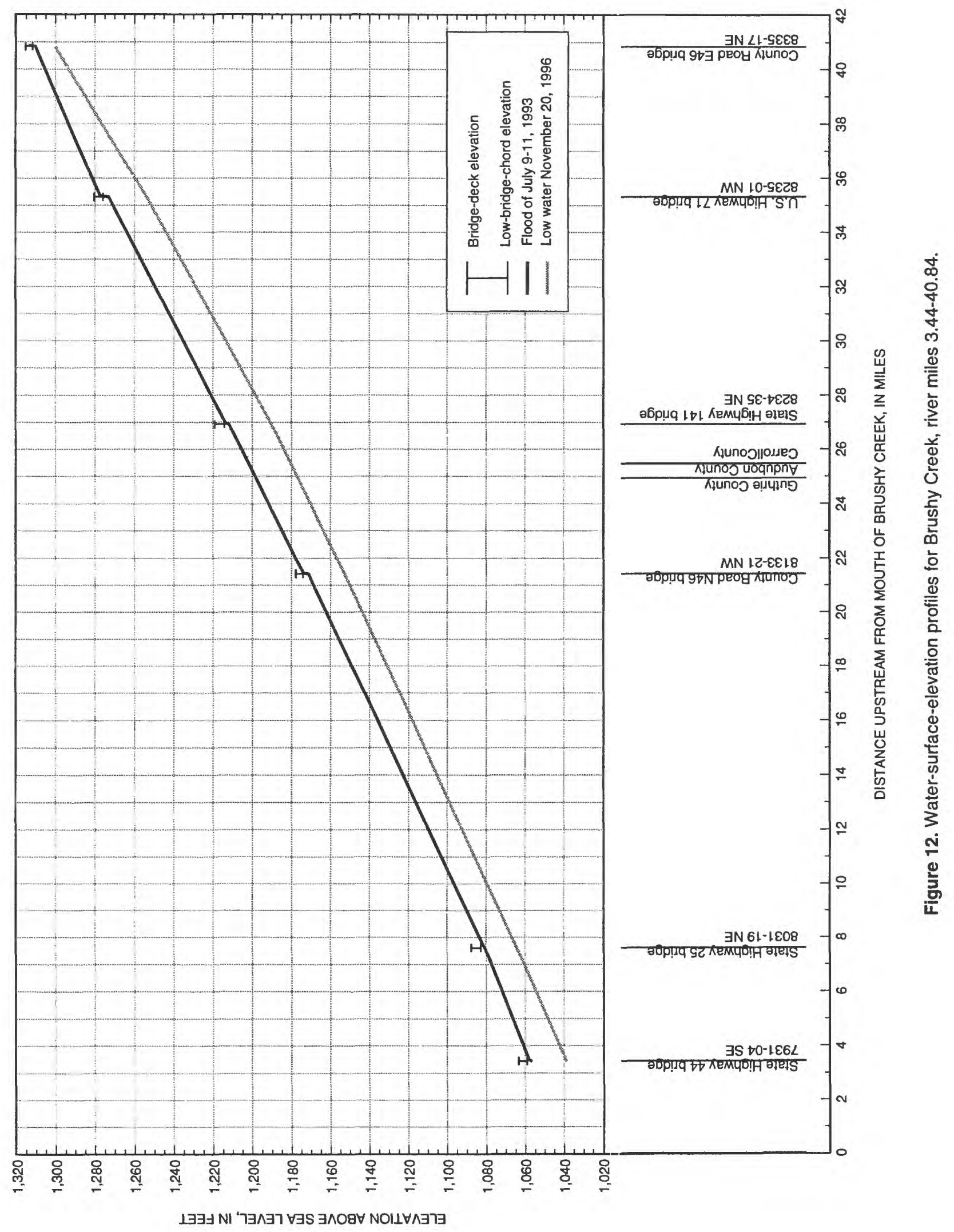




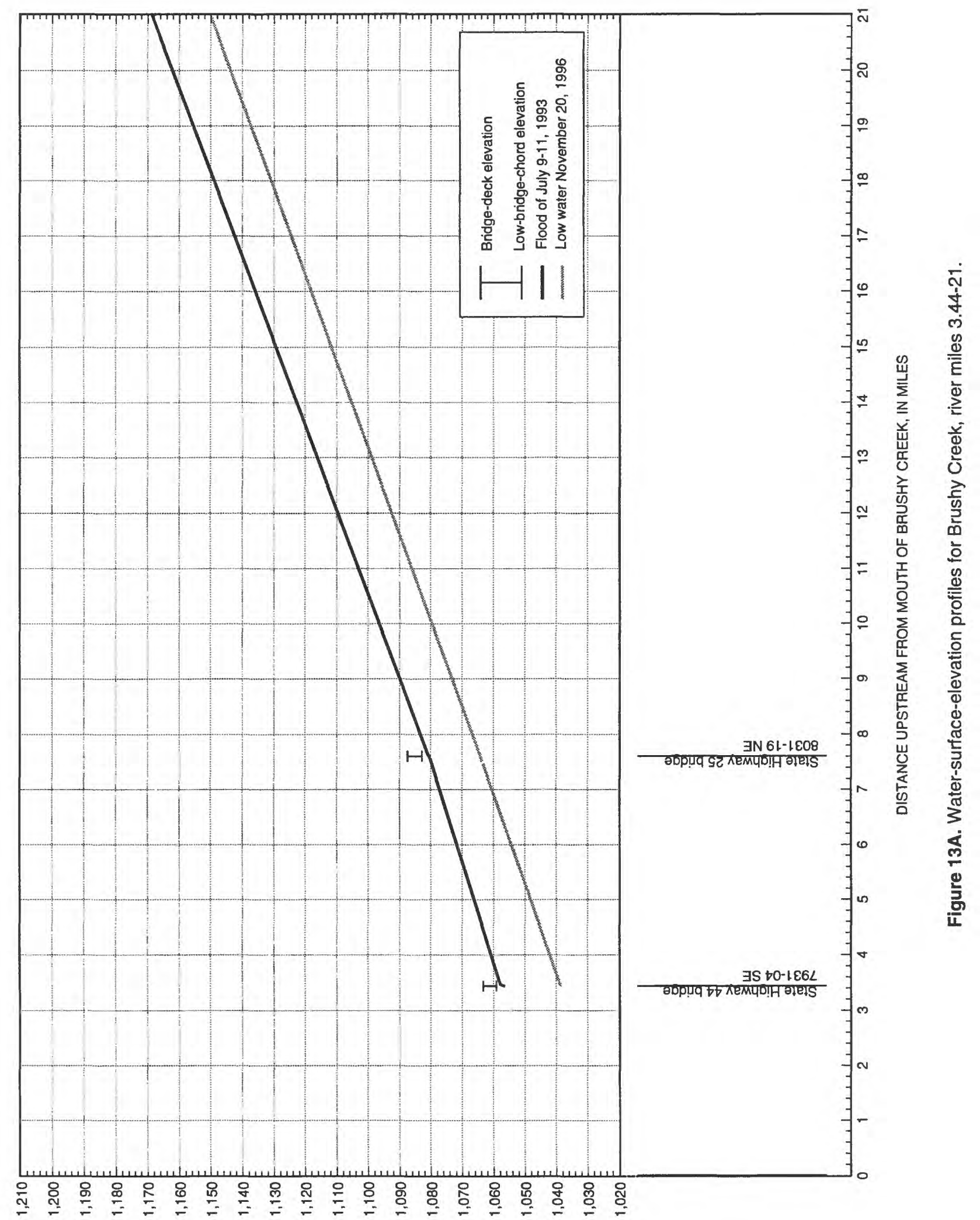

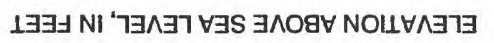




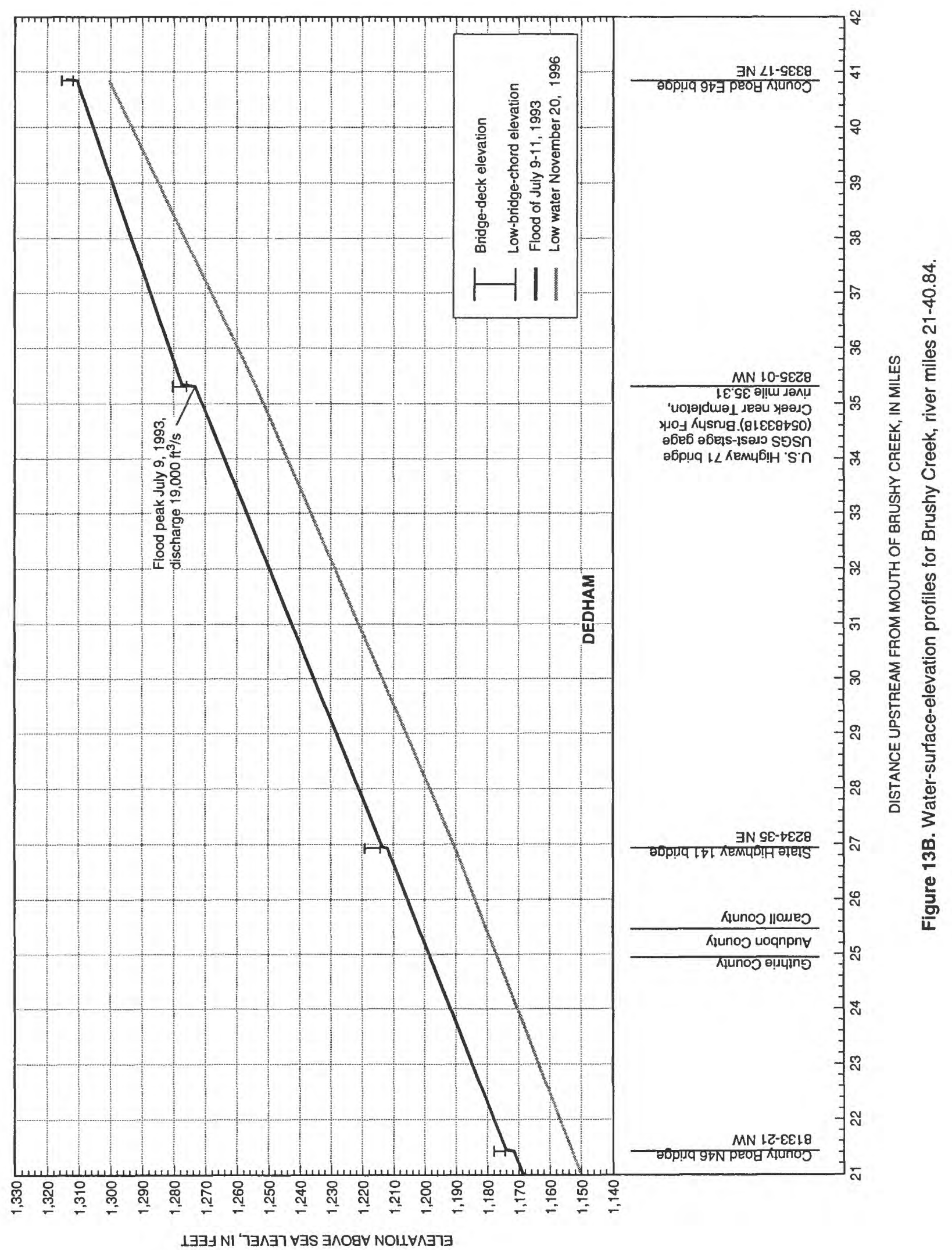




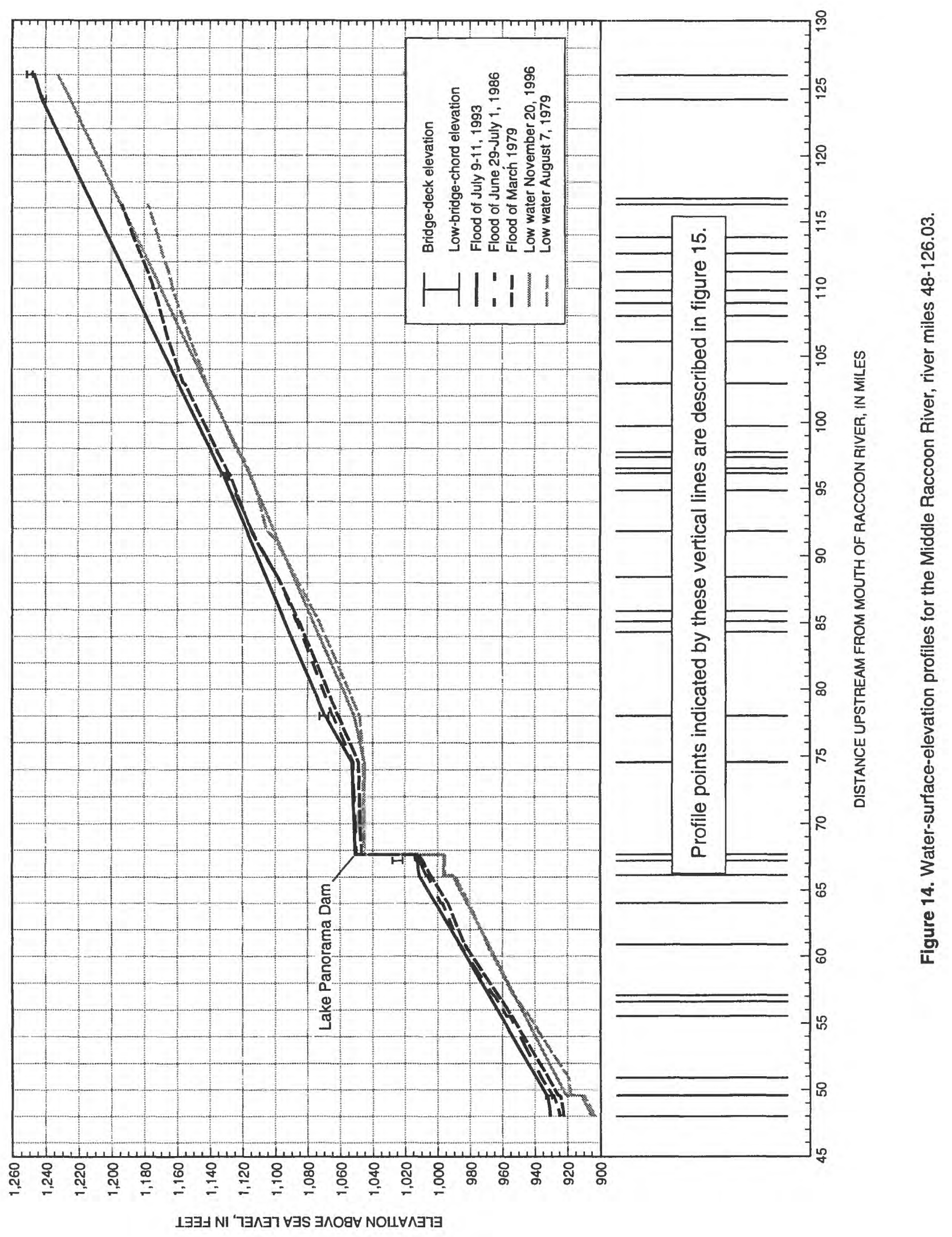




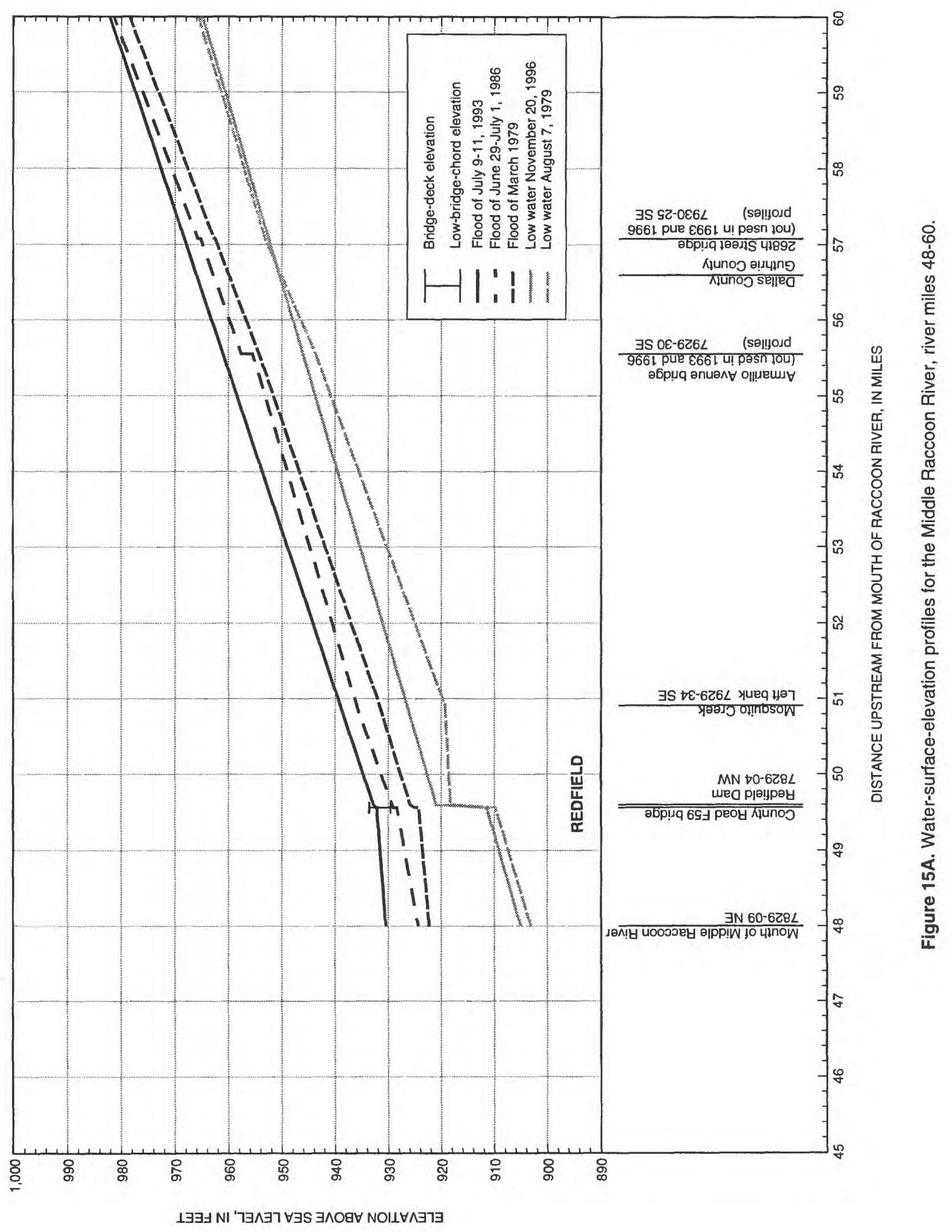




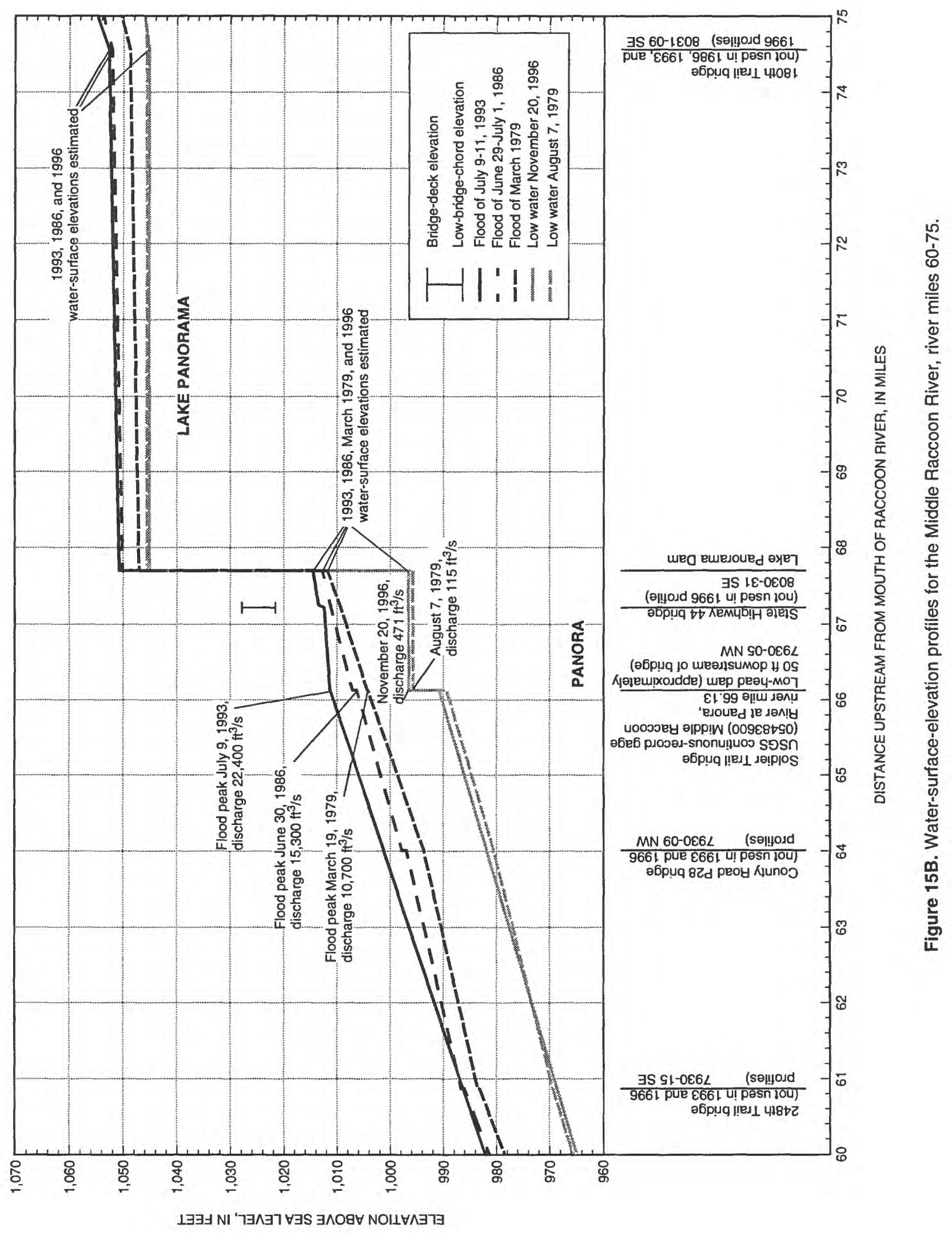




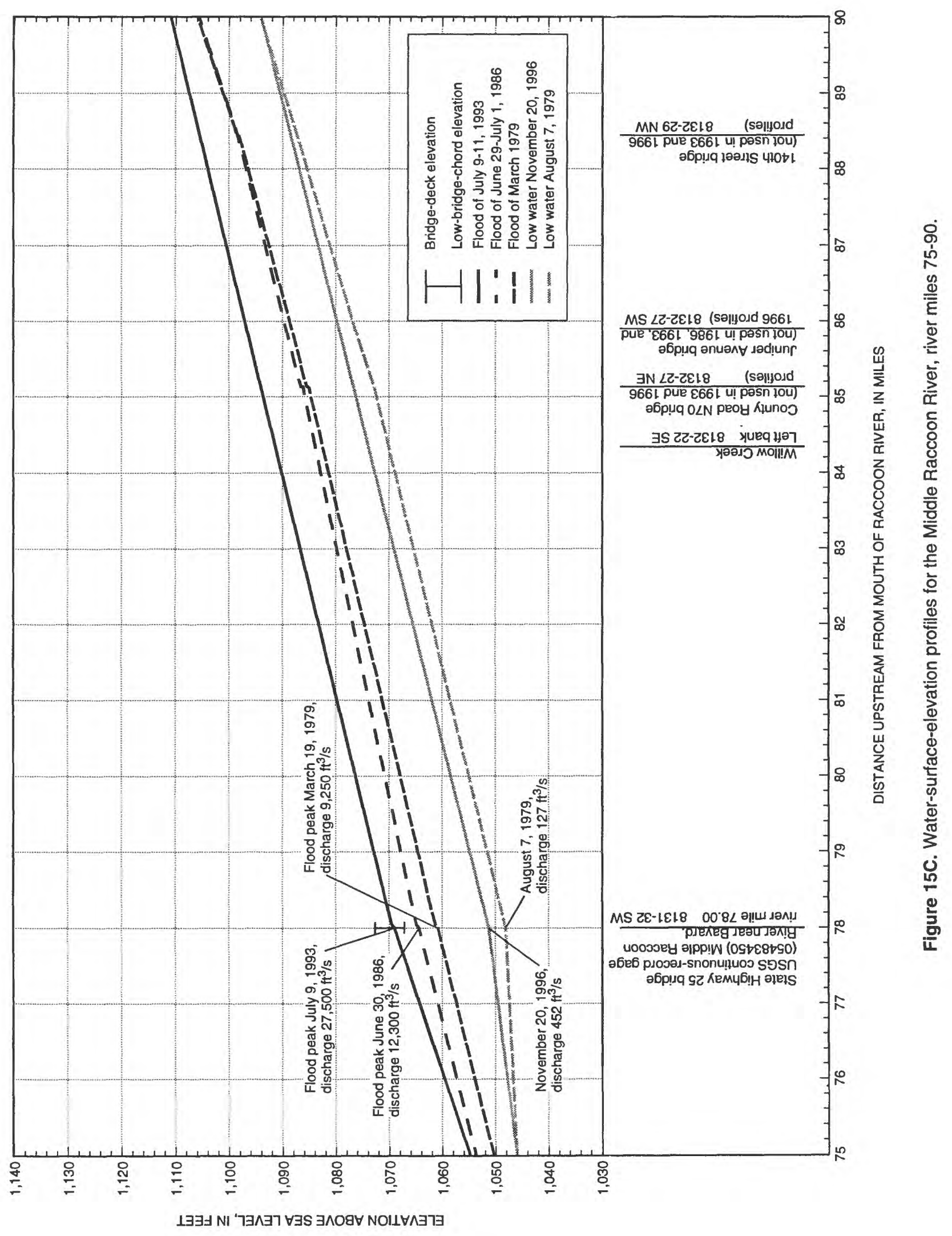




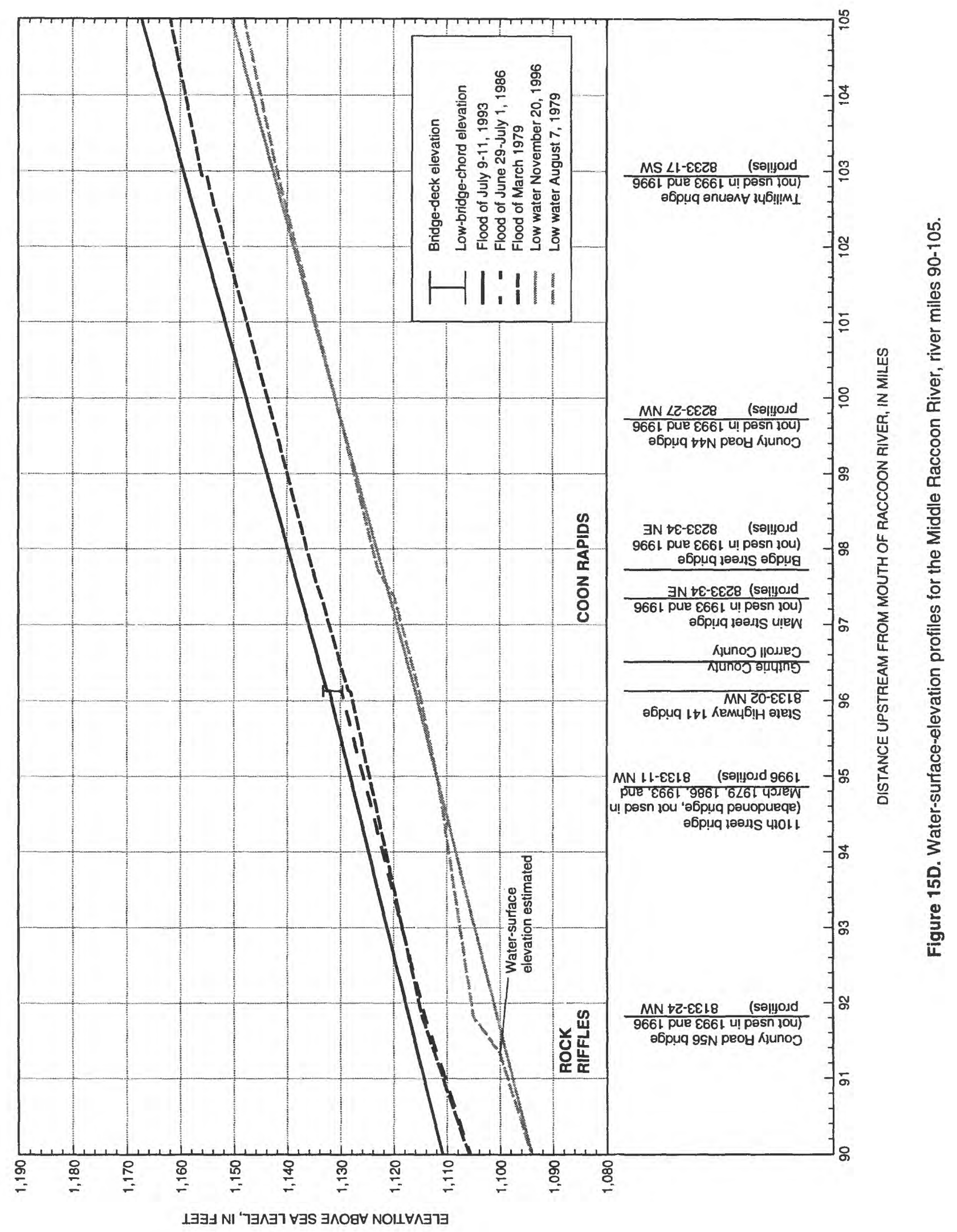




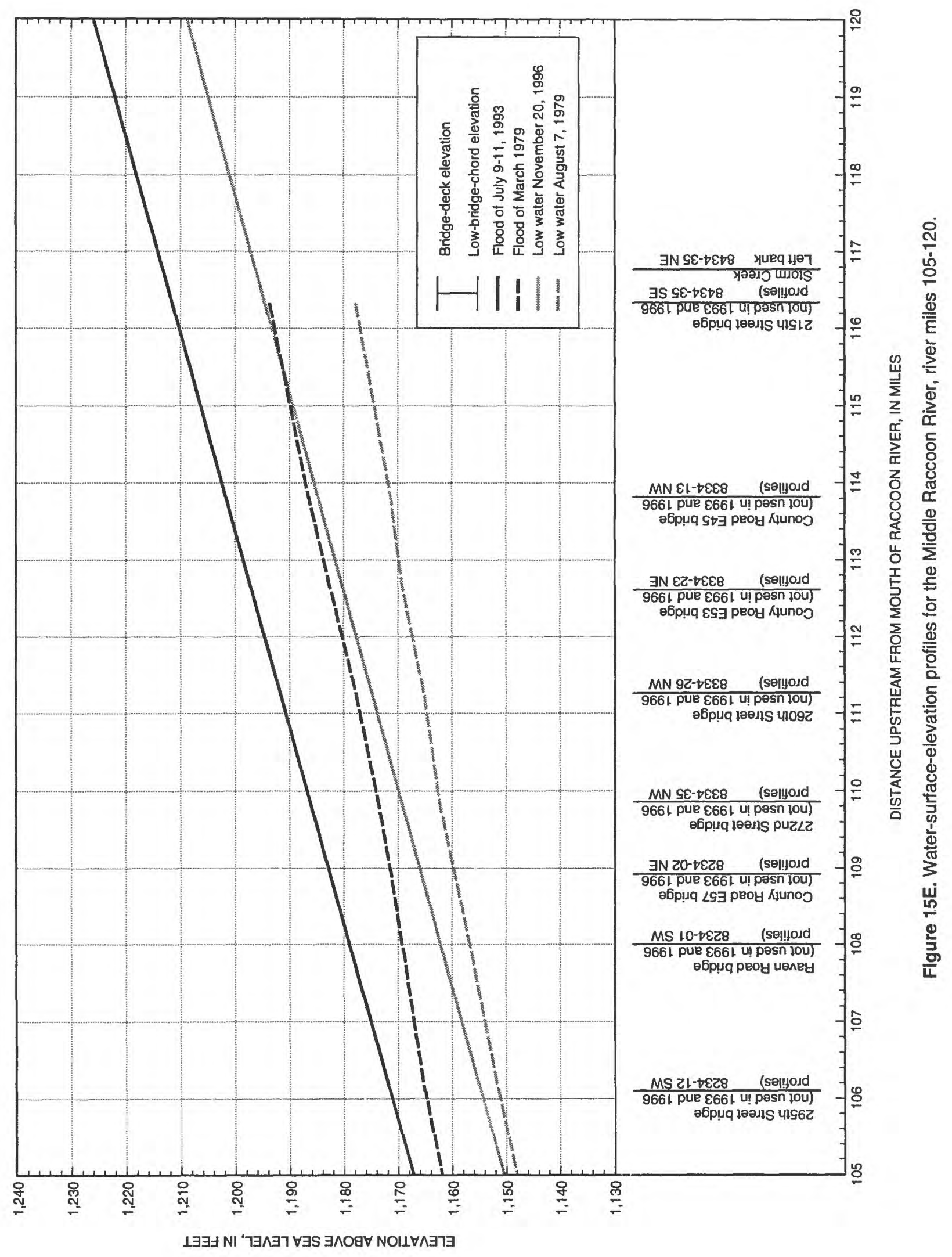




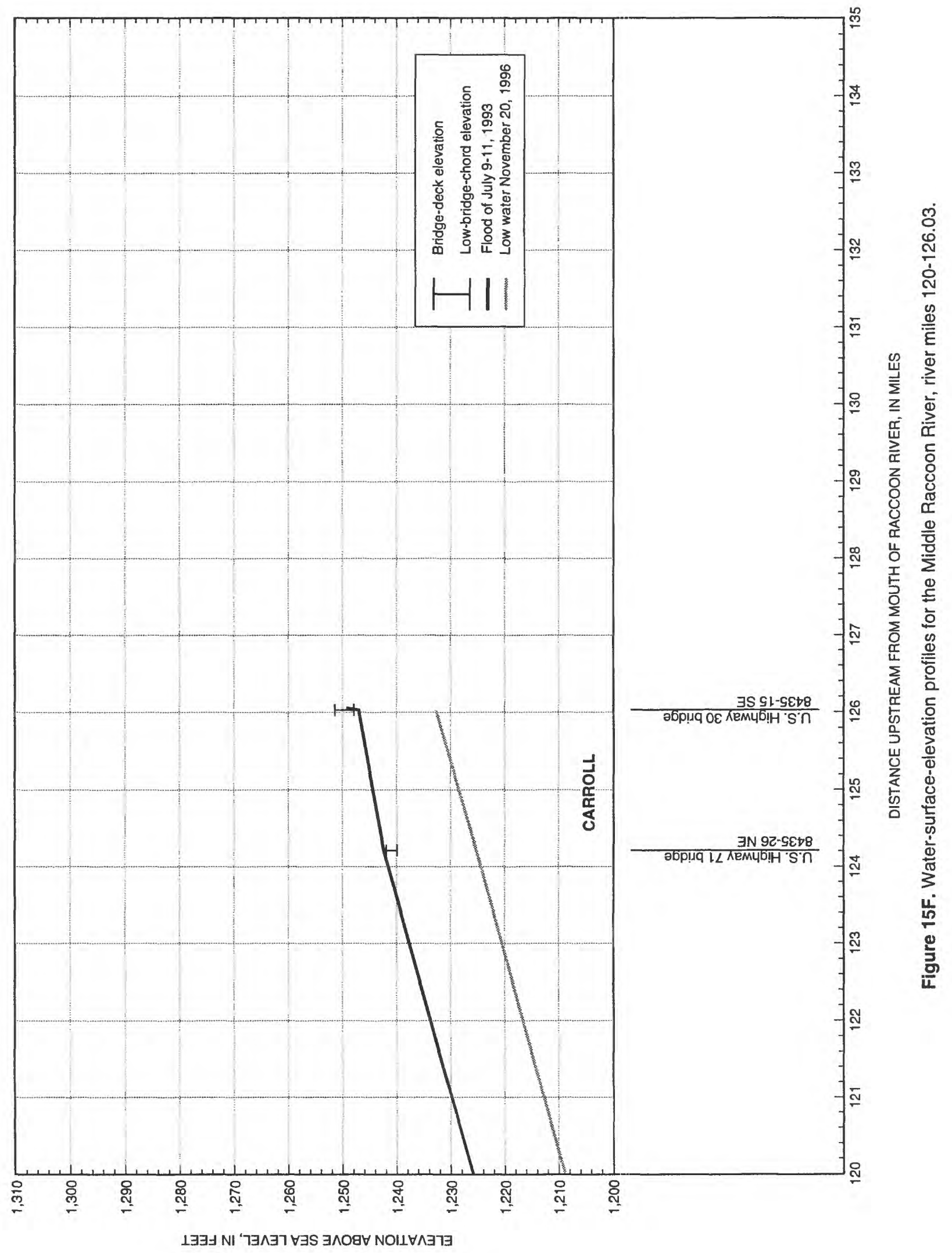




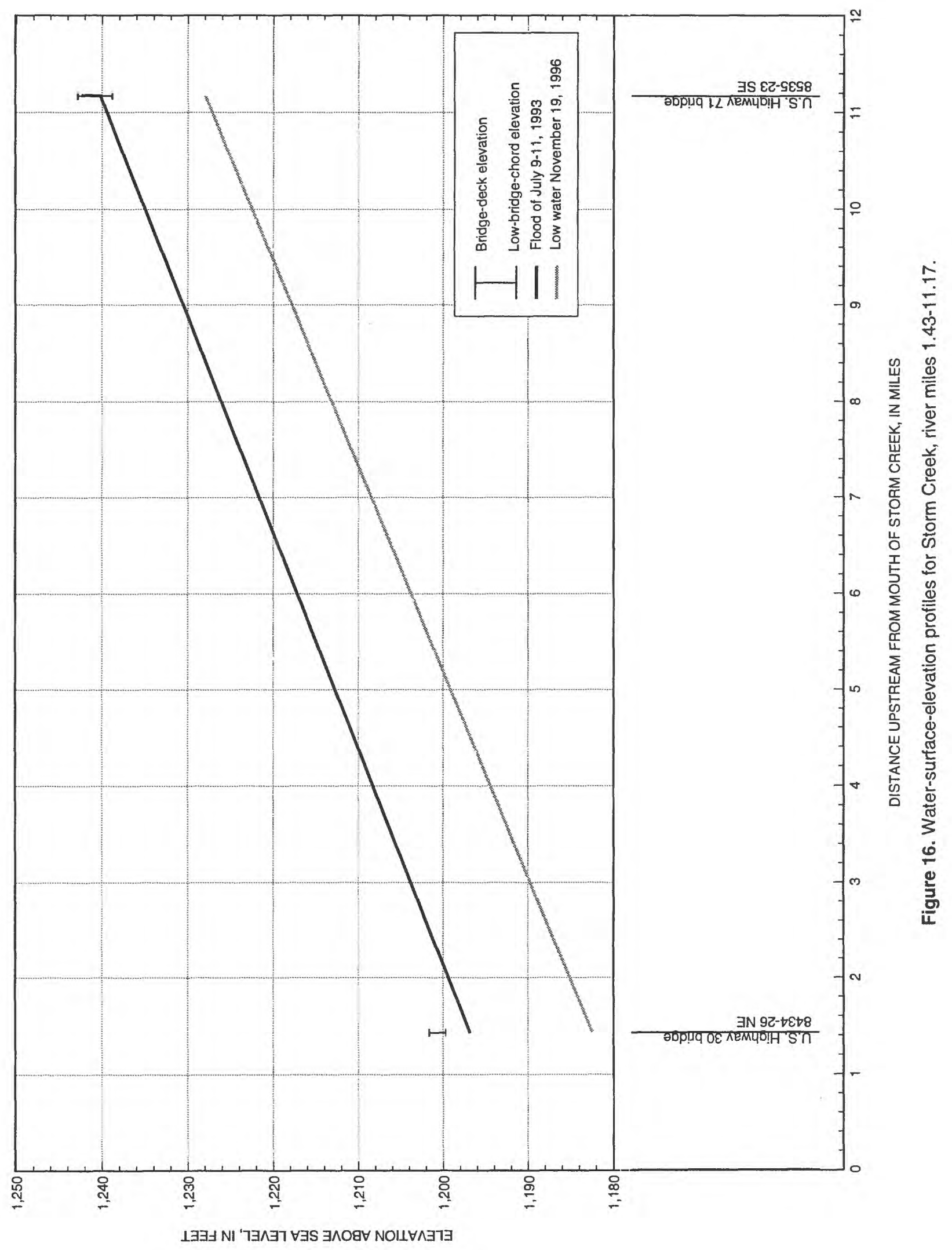


(BLANK PAGE)

$-110-$ 


\section{APPENDIX C}

\section{TEMPORARY BENCH MARKS AND REFERENCE POINTS IN THE RACCOON RIVER BASIN, WEST-CENTRAL IOWA}

To facilitate measuring and referencing the highwater marks used in the flood profiles to a common datum, temporary bench marks (BM) and reference points (RP) were established by the USGS at many of the bridges along the profiled river reaches. All BM and RP elevations listed in this tabulation are referenced to sea level. BMs and RPs are listed only for those bridges used in the July 9-11, 1993, flood profiles. The BMs and RPs were established in the Raccoon River Basin during 1976-79 and 1995-97, with the exception of BMs and RPs established at USGS streamflowgaging stations, which are identified in this tabulation with a reference mark (RM) or RP number. BMs and RPs for other bridges used in the 1979 and 1986 flood profiles are listed in the reports "Floods in the Raccoon River Basin, Iowa" (Heinitz, 1980) and "Floods of 1986 and 1990 in the Raccoon River Basin, West-Central Iowa" (Baebenroth and Schaap, 1992). BM and RP elevations were determined from differential leveling, with the exception of the U.S. Highway 71 culvert crossing Storm Creek, where BM and RP elevations were determined using a Global Positioning System (GPS). Level lines to establish the third-order accuracy of the BMs and RPs shown herein were surveyed from bench marks established and adjusted by the National Mapping Division of the USGS and the National Geodetic Survey. Errors of closure in the USGS level work were adjusted along the level lines to balance the BM and RP elevations. BMs and RPs established by other agencies are noted in the bench-mark descriptions where they occur.
The BMs and RPs are designated by an index number derived from their respective locations using Public Land Survey System coordinates (township, range, section). Within the section, the quarter in which the BM or RP is located is designated by NE, SE, SW, or NW. For example, 7824-10 NW refers to a location in Township 78 North, Range 24 West, northwest quarter of section 10 . A number in parentheses following the quarter-section designation indicates the number of the BM or RP in that particular quarter section. The index number serves to describe the landline location of the BM or RP without further reference in the body of the description.

Standard BMs and RPs such as chiseled squares, arrows, or crosses on concrete; filed arrows or marks on steel; or existing bolts on bridges were used. Existing BMs or RPs were used wherever available, and the agency responsible for the mark, when known, is indicated in the description. RPs are distinguished from BMs in this tabulation by the notation "(REFERENCE POINT)" following the index number. RPs were established to permit water-surface elevations to be determined by use of a tape and weight. The terms "right" and "left" in the descriptions are determined as viewed while facing in the downstream direction.

The user is cautioned that the BMs and RPs listed herein might have been disturbed, destroyed, or moved since the surveys were made. It is the responsibility of the user to determine the condition and the suitability of the BM or RP. 
(BLANK PAGE)

$-112-$ 


\section{TEMPORARY BENCH MARKS AND REFERENCE POINTS IN THE RACCOON RIVER BASIN, WEST-CENTRAL IOWA}

7824-08 NE (1) - At Des Moines, on Fleur Drive bridge over Raccoon River, on right upstream wingwall; chiseled square. (RM 2)

Elevation $813.90 \mathrm{ft}$.

7824-08 NE (2) - (REFERENCE POINT) At Des Moines, on Fleur Drive bridge over Raccoon River, on downstream guardrail between 1 st and 2 nd guardrail posts right of 4th pier from right end of bridge; chiseled arrow.

Elevation $829.05 \mathrm{ft}$.

7825-14 NE (1) - At Des Moines-West Des Moines municipal boundary, on northbound lane of S.W. 63rd Street (State Highway 28) bridge over Raccoon River (downstream bridge), on right downstream wingwall; Iowa Department of Transportation bench mark. Elevation obtained from Iowa Department of Transportation.

Elevation $843.85 \mathrm{ft}$.

7825-14 NE (2) - (REFERENCE POINT) At Des MoinesWest Des Moines municipal boundary, on southbound lane of S.W. 63rd Street (State Highway 28) bridge over Raccoon River (upstream bridge), on 15th guardrail post from left downstream end of bridge; chiseled arrow.

Elevation $831.75 \mathrm{ft}$.

7825-30 SE (1) - At West Des Moines, on northbound lane of Interstate 35 bridge over Raccoon River (downstream bridge), on left downstream wingwall curb; chiseled cross.

Elevation $835.70 \mathrm{ft}$.

7825-30 SE (2) - (REFERENCE POINT) At West Des Moines, on northbound lane of Interstate 35 bridge over Raccoon River (downstream bridge), on 35 th guardrail post from left downstream end of bridge; filed arrow.

Elevation $839.03 \mathrm{ft}$.

7826-30 SE (1) - Approximately 0.3 mi west of Booneville, on County Road F90 bridge over Raccoon River, on right downstream curb; Iowa Highway Commission bench mark.

Elevation $863.18 \mathrm{ft}$.

7826-30 SE (2) - (REFERENCE POINT) Approximately 3.0 mi west of Booneville, on County Road F90 bridge over Raccoon River, on top of 27th guardrail post from right downstream end of bridge; three chiseled marks.

Elevation $865.69 \mathrm{ft}$.
7827-18 NW (1) - Approximately $4.0 \mathrm{mi}$ south of Adel, on U.S Highway 169 bridge over South Raccoon River, on right upstream wingwall curb; Iowa Highway Commission bench mark. Elevation obtained from Dallas County Engineer.

Elevation $885.24 \mathrm{ft}$

7827-18 NW (2) - Approximately 4.0 mi south of Adel, on U.S Highway 169 bridge over South Raccoon River, on top of concrete guardrail at left upstream wingwall; Iowa Highway Commission bench mark.

Elevation $887.02 \mathrm{ft}$.

7827-18 NW (3) - (REFERENCE POINT) Approximately $4.0 \mathrm{mi}$ south of Adel, on U.S. Highway 169 bridge over South Raccoon River, near 21 st old guardrail post hole from left downstream end of bridge; chiseled arrow.

Elevation $886.02 \mathrm{ft}$.

7827-20 NW (1) - Approximately 2.0 mi northwest of Van Meter, on westbound lane of Interstate 80 bridge over South Raccoon River (upstream bridge), on left upstream wingwall curb; Iowa Highway Commission bench mark.

Elevation $879.05 \mathrm{ft}$.

7827-20 NW (2) - Approximately 2.0 mi northwest of Van Meter, on westbound lane of Interstate 80 bridge over South Raccoon River (upstream bridge), on right upstream curb; chiseled cross.

Elevation $880.30 \mathrm{ft}$.

7827-20 NW (3) - (REFERENCE POINT) Approximately $2.0 \mathrm{mi}$ northwest of Van Meter, on eastbound lane of Interstate 80 bridge over South Raccoon River (downstream bridge), on top of 30th guardrail post from left downstream end of bridge; filed arrow.

Elevation $881.17 \mathrm{ft}$.

7827-21 NW (1) - Approximately 1.5 mi northeast of Van Meter, on eastbound lane of Interstate 80 bridge over North Raccoon River (downstream bridge), on right downstream wingwall; Iowa Highway Commission bench mark.

Elevation $875.64 \mathrm{ft}$.

7827-21 NW (2) - (REFERENCE POINT) Approximately 1.5 mi northeast of Van Meter, on eastbound lane of Interstate 80 bridge over North Raccoon River (downstream bridge), on top of 35 th guardrail post from right downstream end of bridge; chiseled arrow.

Elevation $877.38 \mathrm{ft}$. 
7827-22 SW (1) - Approximately 0.3 mi northeast of Van Meter, on County Road R16 bridge over Raccoon River, on right downstream bridge seat and $10 \mathrm{ft}$ upstream of gage house; chiseled square. (RM 15)

Elevation $866.11 \mathrm{ft}$.

7827-22 SW (2) - Approximately 0.3 mi northeast of Van Meter, on County Road R16 bridge over Raccoon River, on right downstream wingwall; chiseled square. (RM 16)

\section{Elevation $870.34 \mathrm{ft}$.}

7827-22 SW (3) - (REFERENCE POINT) Approximately 0.3 mi northeast of Van Meter, on County Road R16 bridge over Raccoon River, on top of guardrail and $1 \mathrm{ft}$ right of wire weight; two chiseled marks. (RP 3)

Elevation $872.35 \mathrm{ft}$.

7829-02 NE (1) - Approximately 2.2 mi east of Redfield, on H Avenue bridge over South Raccoon River, set in concrete 6 in. above ground and $3 \mathrm{ft}$ southwest of gage house; U.S. Geological Survey bench mark. (RM 4)

Elevation $914.94 \mathrm{ft}$.

7829-02 NE (2) - Approximately 2.2 mi east of Redfield, on H Avenue bridge over South Raccoon River, on top of left upstream abutment; chiseled square. (RM 1)

Elevation $924.66 \mathrm{ft}$.

7829-02 NE (3) - (REFERENCE POINT) Approximately 2.2 mi east of Redfield, on $\mathrm{H}$ Avenue bridge over South Raccoon River, on top of 20th guardrail post from left downstream end of bridge; chiseled arrow. (RP 1)

Elevation $925.96 \mathrm{ft}$.

7829-09 NE (1) - Approximately 1.0 mi south of Redfield, on U.S Highway 6 bridge over South Raccoon River, on left upstream wingwall; Iowa Highway Commission bench mark.

Elevation $938.02 \mathrm{ft}$.

7829-09 NE (2) - Approximately 1.0 mi south of Redfield, on U.S Highway 6 bridge over South Raccoon River, on right downstream wingwall; Iowa Highway Commission bench mark.

Elevation $938.24 \mathrm{ft}$.

7829-09 NE (3) - (REFERENCE POINT) Approximately 1.0 mi south of Redfield, on U.S. Highway 6 bridge over South Raccoon River, on top of and at center of 10th concrete guardrail section from left downstream end of bridge; chiseled arrow.

Elevation $939.28 \mathrm{ft}$.
7830-05 SE (1) - Approximately 5.5 mi southwest of Linden, on County Road P28 bridge over South Raccoon River, on left upstream wingwall curb; top of nail.

Elevation $990.46 \mathrm{ft}$.

7830-05 SE (2) - (REFERENCE POINT) Approximately 5.5 mi southwest of Linden, on County Road P28 bridge over South Raccoon River, on top of and at middle of downstream concrete guardrail (four concrete sections from right and four concrete sections from left ends of bridge); chiseled arrow.

Elevation $990.75 \mathrm{ft}$.

7927-06 NE (1) - Approximately 5 mi north of Adel, on State Highway 44 bridge over North Raccoon River, on left downstream wingwall curb; Iowa Highway Commission bench mark.

Elevation $952.84 \mathrm{ft}$.

7927-06 NE (2) - Approximately 5 mi north of Adel, on State Highway 44 bridge over North Raccoon River, on left downstream wingwall; Iowa Department of Transportation bench mark.

Elevation $954.81 \mathrm{ft}$.

7927-06 NE (3) - (REFERENCE POINT) Approximately 5 mi north of Adel, on State Highway 44 bridge over North Raccoon River, left of 48th old guardrail post hole and $426 \mathrm{ft}$ from right downstream end of bridge; chiseled "上".

Elevation $936.39 \mathrm{ft}$.

7927-20 SW (1) - Approximately $1.3 \mathrm{mi}$ north of Adel, on U.S. Highway 169 bridge over North Channel of North Raccoon River, on right downstream wingwall; lowa Highway Commission bench mark.

Elevation $901.82 \mathrm{ft}$.

7927-20 SW (2) - (REFERENCE POINT) Approximately 1.3 mi north of Adel, on U.S. Highway 169 bridge over North Channel of North Raccoon River, on curb on outside of guardrail at center of downstream side of bridge and $270 \mathrm{ft}$ from right end of bridge; chiseled arrow.

Elevation $899.72 \mathrm{ft}$.

7927-29 SE (1) - At Adel, on U.S. Highway 6 bridge over North Raccoon River, on right upstream wingwall; lowa Highway Commission bench mark.

Elevation $895.36 \mathrm{ft}$.

7927-29 SE (2) - (REFERENCE POINT) At Adel, on U.S. Highway 6 bridge over North Raccoon River, near base of lamppost on downstream guardrail; chiseled arrow.

Elevation 895.89 ft. 
7930-05 NW (1) - Approximately $0.2 \mathrm{mi}$ southwest of Panora, on Soldier Trail bridge over Middle Raccoon River, on top of left downstream abutment pile cap; chiseled square. (RM 5)

Elevation 1,015.81 ft.

7930-05 NW (2) - Approximately 0.2 mi southwest of Panora, on Soldier Trail bridge over Middle Raccoon River, on top of left upstream abutment pile cap; chiseled square. (RM 6)

Elevation 1,015.77 ft.

7931-04 SE (1) - Approximately $1.8 \mathrm{mi}$ east of Guthrie Center, on State Highway 44 bridge over Brushy Creek, on right downstream wingwall; chiseled square.

Elevation $1066.58 \mathrm{ft}$.

7931-04 SE (2) - Approximately $1.8 \mathrm{mi}$ east of Guthrie Center, on State Highway 44 bridge over Brushy Creek, on left upstream wingwall; chiseled cross.

Elevation $1066.12 \mathrm{ft}$.

7931-04 SE (3) - (REFERENCE POINT) Approximately $1.8 \mathrm{mi}$ east of Guthrie Center, on State Highway 44 bridge over Brushy Creek, on downstream guardrail and $73 \mathrm{ft}$ from right end of bridge; chiseled arrow.

Elevation 1,065.29 ft.

7931-06 SW (1) - At west edge of Guthrie Center, on State Highway 44 bridge over South Raccoon River, on right upstream wingwall; Iowa Highway Commission bench mark.

Elevation 1,080.05 ft.

7931-06 SW (2) - (REFERENCE POINT) At west edge of Guthrie Center, on State Highway 44 bridge over South Raccoon River, on top of 5th upstream concrete guardrail section and approximately $64 \mathrm{ft}$ from right end of bridge; chiseled arrow.

Elevation 1,080.63 ft.

7931-07 NE (1) - Near south edge of Guthrie Center, on State Highway 25 bridge over South Raccoon River, on right downstream bridge abutment; Iowa Department of Transportation bench mark.

Elevation 1,076.98 ft.

7931-07 NE (2) - Near south edge of Guthrie Center, on State Highway 25 bridge over South Raccoon River, on left upstream bridge abutment; Iowa Department of Transportation bench mark.

Elevation 1,076.95 ft.
7931-07 NE (3) - (REFERENCE POINT) Near south edge of Guthrie Center, on State Highway 25 bridge over South Raccoon River, on downstream concrete guardrail $57 \mathrm{ft}$ from right end of bridge; chiseled arrow.

Elevation 1,077.18 ft.

8030-31 SE (1) - Approximately $0.7 \mathrm{mi}$ west of Panora, on State Highway 44 bridge over Middle Raccoon River, on right downstream wingwall curb; Iowa Highway Commission bench mark.

Elevation 1,036.19 ft.

8030-31 SE (2) - Approximately $0.7 \mathrm{mi}$ west of Panora, on State Highway 44 bridge over Middle Raccoon River, on left upstream wingwall curb; lowa Highway Commission bench mark.

Elevation 1,029.93 ft.

8031-19 NE (1) - Approximately 2.8 mi north of Guthrie Center, on State Highway 25 bridge over Brushy Creek, on left upstream wingwall; Iowa Highway Commission bench mark.

Elevation 1,089.88 ft.

8031-19 NE (2) - Approximately 2.8 mi north of Guthrie Center, on State Highway 25 bridge over Brushy Creek, on right downstream wingwall; chiseled square.

Elevation 1,090.42 ft.

8031-19 NE (3) -(REFERENCE POINT) Approximately 2.8 mi north of Guthrie Center, on State Highway 25 bridge over Brushy Creek, on downstream guardrail $114 \mathrm{ft}$ from right end of bridge; chiseled arrow.

Elevation 1,090.44 ft.

8128-08 SE (1) - Approximately $1.5 \mathrm{mi}$ west of Perry, on State Highway 141 bridge over North Raccoon River, on left upstream wingwall curb; Iowa Highway Commission bench mark.

Elevation 944.53 ft.

8128-08 SE (2) - (REFERENCE POINT) Approximately $1.5 \mathrm{mi}$ west of Perry, on State Highway 141 bridge over North Raccoon River, left of 11 th old guardrail post hole from left downstream end of bridge; top of bolt.

Elevation $944.40 \mathrm{ft}$.

8131-32 SW (1) - Approximately $5.8 \mathrm{mi}$ southeast of Bayard, on State Highway 25 bridge over Middle Raccoon River, on top of left end of downstream concrete barrier of bridge, chiseled square. (RM9)

Elevation 1,074.84 ft. 
8131-32 SW (2) - Approximately 5.8 mi southeast of Bayard, on State Highway 25 bridge over Middle Raccoon River, set $1 \mathrm{ft}$ south of gage house; U.S. Geological Survey bench mark. (RM11)

\section{Elevation 1,067.67 ft.}

8133-02 NW (1) - Approximately $1.0 \mathrm{mi}$ southeast of Coon Rapids, on State Highway 141 bridge over Middle Raccoon River, on left upstream wingwall; Iowa Department of Transportation bench mark.

Elevation 1,136.13 ft

8133-02 NW (2) - (REFERENCE POINT) Approximately 1.0 mi southeast of Coon Rapids, on State Highway 141 bridge over Middle Raccoon River, on top of 16th guardrail post from right downstream end of bridge; filed arrow.

\section{Elevation 1,136.10 ft.}

8133-21 NW (1) - Approximately $3.7 \mathrm{mi}$ southwest of Coon Rapids, on County Road N46 bridge over Brushy Creek, on left downstream wingwall; chiseled square.

Elevation 1,180.62 ft.

8133-21 NW (2) - Approximately $3.7 \mathrm{mi}$ southwest of Coon Rapids, on County Road N46 bridge over Brushy Creek, on right upstream wingwall; chiseled cross.

Elevation 1,180.62 ft.

8133-21 NW (3) - (REFERENCE POINT) Approximately 3.7 mi southwest of Coon Rapids, on County Road N46 bridge over Brushy Creek, on top of 8th concrete guardrail post from right downstream end of bridge; chiseled arrow.

Elevation 1,180.77 ft.

8133-29 SW (1) - Approximately 5.7 mi southwest of Coon Rapids, on County Road N46 bridge over South Raccoon River, on right upstream wingwall; chiseled square.

Elevation 1,244.41 ft.

8133-29 SW (2) - Approximately 5.7 mi southwest of Coon Rapids, on County Road N46 bridge over South Raccoon River, on left downstream wingwall curb; chiseled cross.

Elevation 1,242.37 ft.

8133-29 SW (3) - (REFERENCE POINT) Approximately 5.7 mi southwest of Coon Rapids, on County Road N46 bridge over South Raccoon River, on right side of 4th concrete guardrail post from left downstream end of bridge; chiseled arrow.

Elevation 1,245.04
8229-18 SW (1) - Approximately 4.0 mi east of Cooper, on County Road E57 bridge over North Raccoon River, on right downstream wingwall; bolt in concrete.

Elevation $969.03 \mathrm{ft}$.

8229-18 SW (2) - Approximately $4.0 \mathrm{mi}$ east of Cooper, on County Road E57 bridge over North Raccoon River, on left upstream wingwall; bolt in concrete.

Elevation $969.00 \mathrm{ft}$.

8229-18 SW (3) - (REFERENCE POINT) Approximately 4.0 mi east of Cooper, on County Road E57 bridge over North Raccoon River, on top of 21st guardrail post from right downstream end of bridge; chiseled arrow.

Elevation $970.70 \mathrm{ft}$.

8234-35 NE (1) - Approximately 3.3 mi southeast of Dedham, on State Highway 141 bridge over Brushy Creek, on left downstream wingwall; Iowa Highway Commission bench mark.

Elevation 1,221.67 ft.

8234-35 NE (2) - Approximately 3.3 mi southeast of Dedham, on State Highway 141 bridge over Brushy Creek, on left upstream wingwall; chiseled cross.

Elevation 1,221.60 ft.

8234-35 NE (3) -(REFERENCE POINT) Approximately 3.3 mi southeast of Dedham, on State Highway 141 bridge over Brushy Creek, $111 \mathrm{ft}$ from left downstream end of bridge; chiseled arrow.

Elevation 1,219.92 ft.

8235-01 NW (1) - Approximately 4 mi northeast of Templeton, on U.S. Highway 71 bridge over Brushy Creek, on left downstream abutment; U.S. Geological Survey brass tablet stamped "41 PJH 1969."

Elevation 1,286. $295 \mathrm{ft}$.

8235-01 NW (2) - Approximately 4 mi northeast of Templeton, on U.S. Highway 71 bridge over Brushy Creek, on left upstream abutment; chiseled cross.

Elevation 1,286.34 ft.

8235-01 NW (3) - (REFERENCE POINT) Approximately 4 mi northeast of Templeton, on U.S. Highway 71 bridge over Brushy Creek, on top of downstream concrete guardrail $108 \mathrm{ft}$ from left end of bridge; chiseled arrow.

Elevation 1,284.15 ft.

8330-20 NW (1)- Approximately 1.9 mi south of Jefferson, on State Highway 4 bridge over North Raccoon River, on top of right downstream guardrail; Iowa Highway Commission bench mark. (RM 12)

Elevation 1,010.00 ft. 
8330-20 NW (2) - Approximately 1.9 mi south of Jefferson, on State Highway 4 bridge over North Raccoon River, set in cement $8 \mathrm{ft}$ east of gage house; U.S. Geological Survey bench mark. (RM 15)

Elevation 1,006.70 ft.

8331-04 NW (1)- Approximately 4.6 mi northwest of Jefferson, on U.S. Highway 30 bridge over North Raccoon River, on left upstream wingwall curb; chiseled square.

Elevation 1,020.16 ft.

8331-04 NW (2)- Approximately 4.6 mi northwest of Jefferson, on U.S. Highway 30 bridge over North Raccoon River, on right upstream wingwall curb; chiseled cross.

\section{Elevation 1,016.40 ft.}

8335-17 NE (1) -Approximately $1.2 \mathrm{mi}$ west of Roselle, on County Road E46 bridge over Brushy Creek, on left upstream wingwall; chiseled square.

Elevation 1,318.21 ft.

8335-17 NE (2) -(REFERENCE POINT) Approximately 1.2 mi west of Roselle, on County Road E46 bridge over Brushy Creek, $26 \mathrm{ft}$ from left upstream end of bridge; chiseled mark.

Elevation 1,318.10 ft.

8434-26 NE (1) - Approximately 4.1 mi east of Carroll, on U.S. Highway 30 bridge over Storm Creek, on right downstream wingwall; chiseled square.

Elevation 1,204.55 ft.

8434-26 NE (2) - Approximately 4.1 mi east of Carroll, on U.S. Highway 30 bridge over Storm Creek, on left upstream wingwall curb; chiseled cross.

Elevation 1,202.27 ft.

8434-26 NE (3) - (REFERENCE POINT) Approximately $4.1 \mathrm{mi}$ east of Carroll, on U.S. Highway 30 bridge over Storm Creek, $50 \mathrm{ft}$ from left downstream end of bridge; chiseled arrow.

Elevation 1,202.16 ft.
8435-15 SE (1) - At northwest edge of Carroll, on U.S. Highway 30 bridge over Middle Raccoon River, on left upstream wingwall; chiseled cross.

Elevation 1,255.63 ft.

8435-15 SE (2) - At northwest edge of Carroll, on U.S. Highway 30 bridge over Middle Raccoon River, on right upstream wingwall; chiseled square.

Elevation 1,253.83 ft.

8435-15 SE (3) -(REFERENCE POINT) At northwest edge of Carroll, on U.S. Highway 30 bridge over Middle Raccoon River, $66 \mathrm{ft}$ from left upstream end of bridge; chiseled arrow.

Elevation 1,254.70 ft.

8435-26 NE (1) - At southwest edge of Carroll, on U.S. Highway 71 bridge over Middle Raccoon River, on right downstream wingwall; Iowa Highway Commission bench mark.

Elevation 1,244.28 ft.

8435-26 NE (2) - At southwest edge of Carroll, on U.S. Highway 71 bridge over Middle Raccoon River, on left upstream wingwall; chiseled cross.

Elevation 1,244.73 ft.

8435-26 NE (3) -(REFERENCE POINT) At southwest edge of Carroll, on U.S. Highway 71 bridge over Middle Raccoon River, $85 \mathrm{ft}$ from left upstream end of bridge; chiseled arrow.

Elevation 1,244.82 ft.

8535-23 SE (1) - Approximately 1.5 mi east of Mount Carmel, on U.S. Highway 71 culvert over Storm Creek, on top of and at center of upstream culvert headwall; Iowa Highway Commission bench mark. Elevation determined using GPS.

Elevation 1,241.61 ft.

8535-23 SE (2) - (REFERENCE POINT) Approximately 1.5 mi east of Mount Carmel, on U.S. Highway 71 culvert over Storm Creek, on top of and $6 \mathrm{ft}$ from left end of downstream culvert headwall; chiseled arrow. Elevation determined using GPS.

Elevation 1,241.06 ft. 